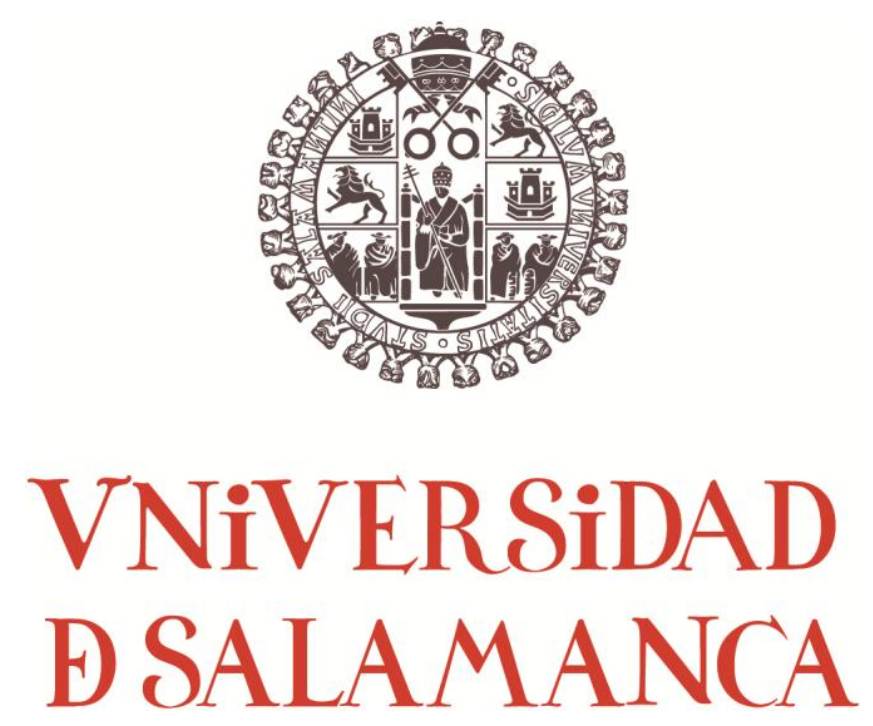

TESIS DOCTORAL

\title{
Análisis del promotor del gen del receptor de prostaglandina D2, PTGDR, en pacientes con asma
}

Virginia García Solaesa

\section{DIRECTORES}

Dr. D. Félix Lorente Toledano

Dra. Dña. María Isidoro García

Dr. D. Ignacio J. Dávila González 


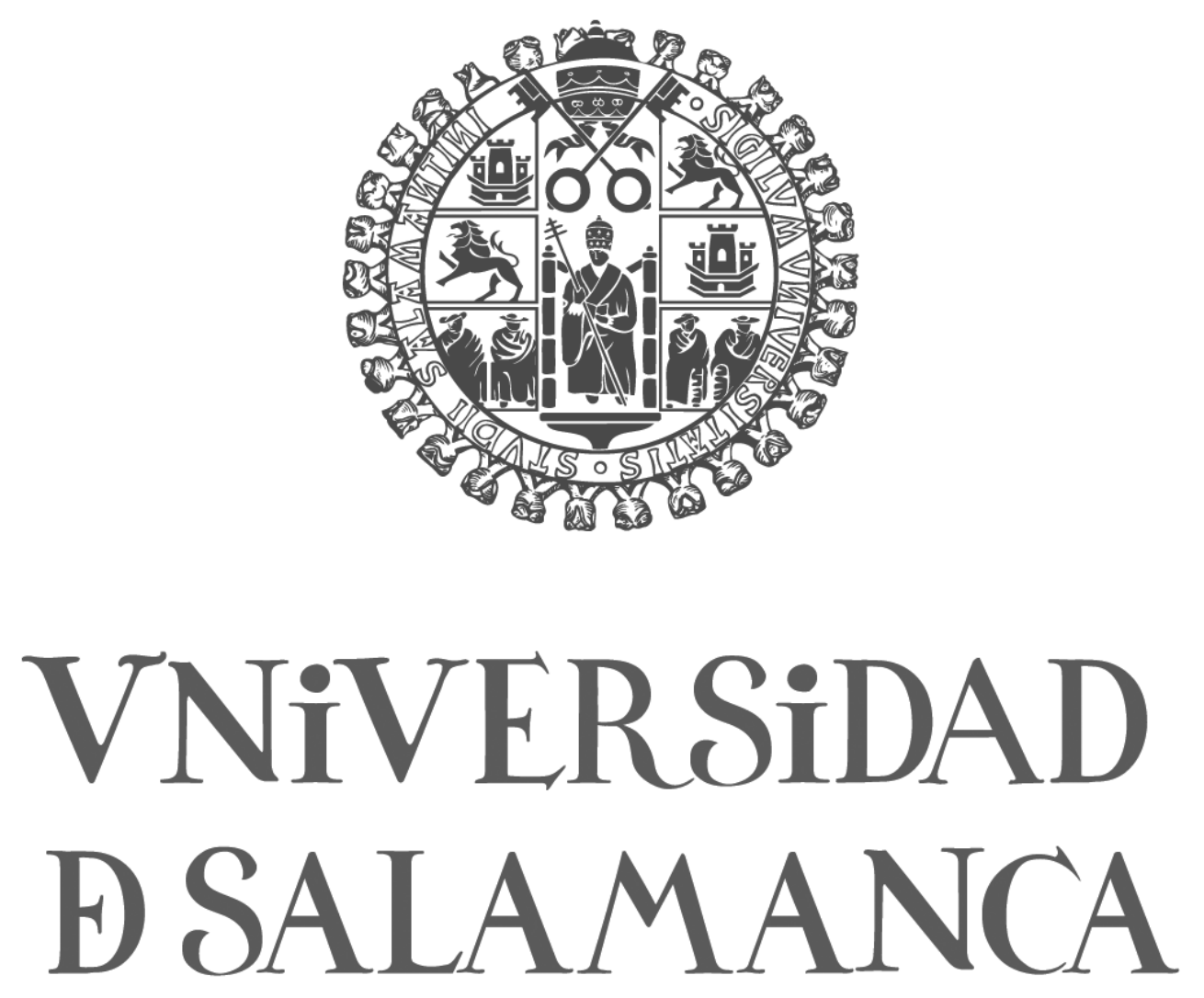

DEPARTAMENTO DE OBSTETRICIA, GINECOLOGÍA Y PEDIATRÍA

\section{Análisis del promotor del gen del receptor de prostaglandina D2, PTGDR, en pacientes con asma}



El Dr. D. Félix Lorente Toledano, Catedrático del Departamento de Obstetricia, Ginecología y Pediatría, la Dra. Dña. María Isidoro García, Profesora Asociada de Medicina Molecular del Departamento de Medicina y el Dr. D. Ignacio J. Dávila González, Profesor Asociado de Alergología del Departamento de Obstetricia, Ginecología y Pediatría

\section{CERTIFICAN:}

Que el trabajo titulado "Análisis del promotor del gen del receptor de prostaglandina D2, PTGDR, en pacientes con asma", que presenta la licenciada en Bioquímica Dña. Virginia García Solaesa ha sido realizado bajo nuestra dirección en el Departamento de Obstetricia, Ginecología y Pediatría y reúne, a nuestro juicio, originalidad y contenidos suficientes para que sea presentado ante el Tribunal correspondiente y optar al grado de Doctora por la Universidad de Salamanca.

Y para que así conste y a los efectos oportunos, expedimos el presente certificado en Salamanca a 5 de Marzo de 2012.

Fdo: Dr. Félix Lorente Toledano

Fdo: Dra. María Isidoro García

Fdo: Dr. Ignacio J. Dávila González 

A mis padres

A mi hermana

A David

......por quererme y cuidarme siempre 



\section{Agradecimientos}

Son muchas las personas a las que agradecer su ayuda, ánimo y compañía en cada una de las etapas de este trabajo:

A los directores de esta tesis doctoral, los doctores Félix Lorente Toledano, Ignacio Dávila González y María García Isidoro; por el gran grupo de trabajo que han constituido, en el cual he tenido la oportunidad de aprender y crecer como profesional y como persona.

A Cati, por su ayuda y su amistad; por su manera de trabajar y de enseñar.

A Juana, por su amistad, su apoyo y su ayuda en esta tesis y en los cuatro años de trabajo en Salamanca. Por contagiar de alegría y buen humor el laboratorio.

A Sara por su gran amistad, por brindarme su ayuda y colaboración siempre.

A mis compañeros del Laboratorio de Inmunoalergia, Laura, Choni, María Luisa, Marta, Iñaki, Marien, David, y especialmente a Carmen por su cariño y sus buenos consejos.

A todo el personal del Servicio de Inmunoalergia, por su colaboración en esta tesis y por hacerme sentir como uno más desde el primer día.

A los pacientes por participar en el estudio y por ser el objeto del mismo.

A mis compañeros del Servicio de Bioquímica, por la complicidad con la que aprendimos a trabajar, con la que disfrutábamos de nuestro trabajo y nuestro tiempo libre.

A mis padres por quererme y creer en mí; por su sacrificio y por dármelo todo para llegar hasta aquí. A mi hermana Ángela, por sus acertados consejos y su vitalidad.

A David por su cariño, por animarme en los días malos y alegrarse conmigo en los buenos. 

"Si tienes el anhelo de llevar a cabo una investigación científica adquiere el aprendizaje preciso y por todos los medios hazlo. Difícilmente alguna otra cosa te dará tanta satisfacción y, sobre todo, tal sentido de logro".

\author{
Severo Ochoa
}





\section{INDiCE}

\section{INTR ODVCCiீ́N}

1.1 Definición .................................................................... 3

1.2 Epidemiología................................................... 4

1.3 Características clínicas ...................................... 6

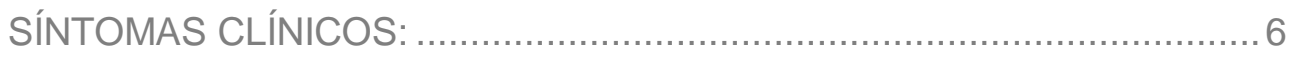

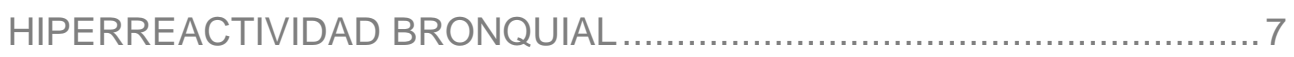

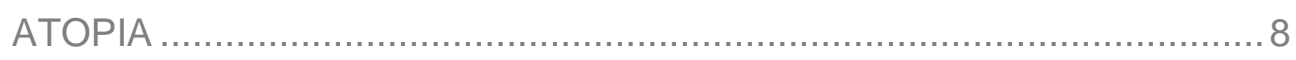

1.4 Diagnóstico.......................................................... 10

1.5 Etiopatogenia ..................................................... 12

INFLAMACIÓN DE LAS VÍAS RESPIRATORIAS ................................. 13

HIPERREACTIVIDAD BRONQUIAL (HRB) ..................................... 22

OBSTRUCCIÓN AL FLUJO AÉREO ….............................................23

REESTRUCTURACIÓN DE LA VÍAS RESPIRATORIAS .......................23

$1.6 \quad$ Etiología.......................................................... 26

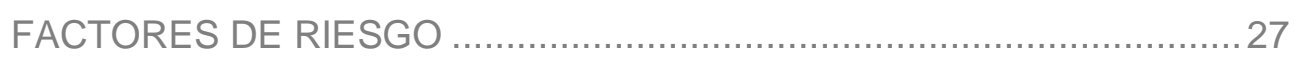

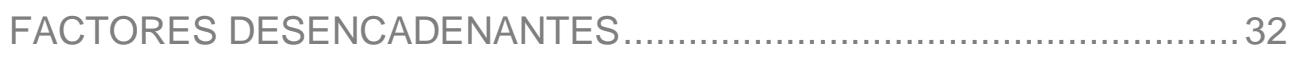

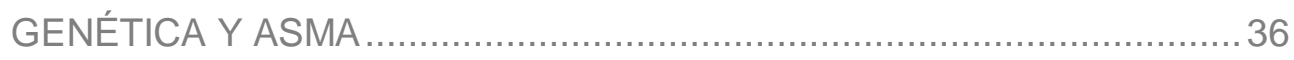

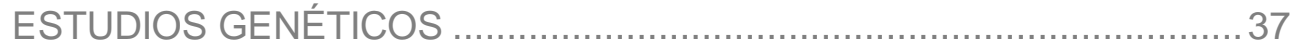

GENES ASOCIADOS AL ASMA .................................................... 43

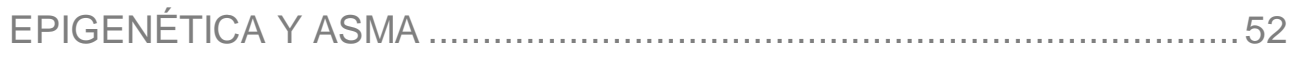

FARMACOGENÉTICA EN EL TRATAMIENTO DEL ASMA ....................54 


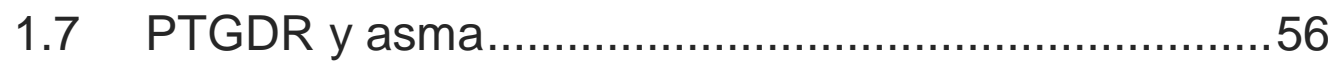

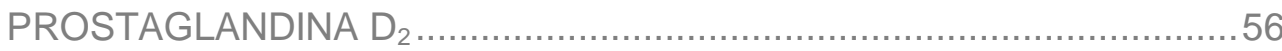

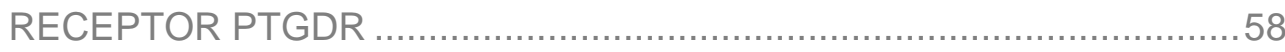

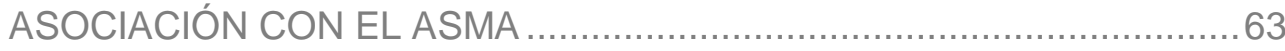

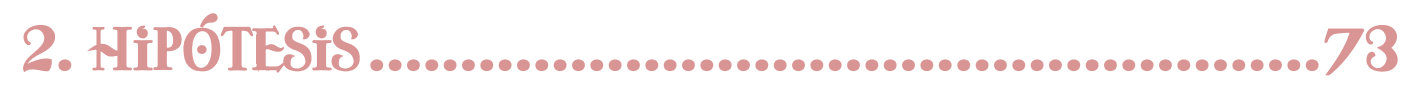

3. OBJETIIVOS..................................................77

4. MATERIIAL Y MÉTODOS ..................................81

4.1 Estudio de casos y controles .................................. 81

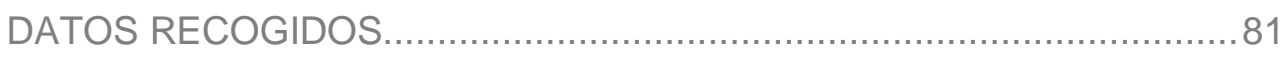

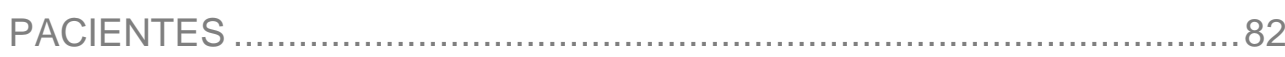

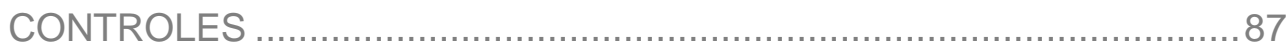

4.2 Análisis molecular .............................................. 87

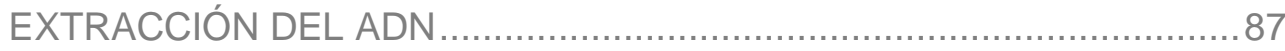

ANÁLISIS DE GENOTIPOS Y HAPLOTIPOS.........................................

4.3 Análisis funcional ...............................................105

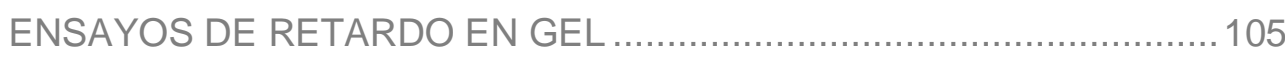

ESTUDIO IN SILICO DE LAS VARIANTES ……………………..........118

IDENTIFICACIÓN DE FACTORES DE TRANSCRIPCIÓN ......................119

4.4 Estudio estadístico de asociación génica ................138

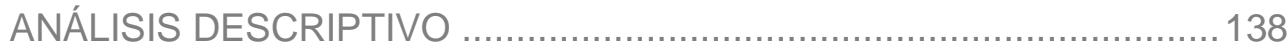

ANÁLISIS BIVARIANTE Y MULTIVARIANTE ......................................138 
5.1 Estudio estadístico de asociación génica ................. 143

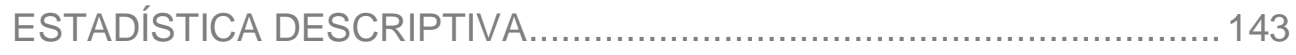

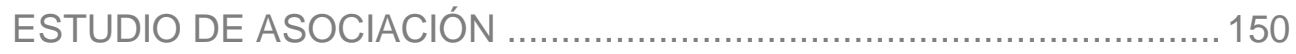

5.2 Estudio funcional del promotor de PTGDR.............160

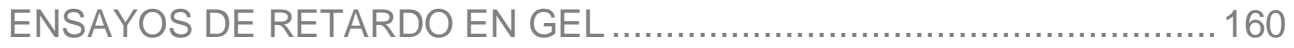

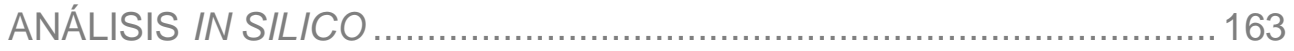

IDENTIFICACIÓN DE FACTORES DE TRANSCRIPCIÓN......................166

6. DíSCVSî́|N......................................................175

6.1 Asociación génica del gen PTGDR con el asma..... 176

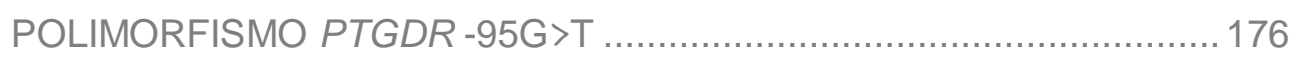

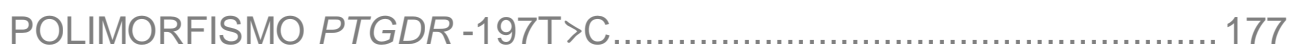

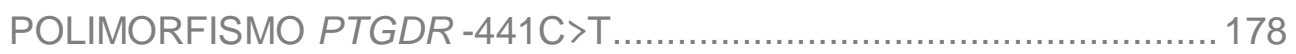

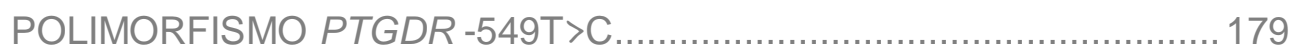

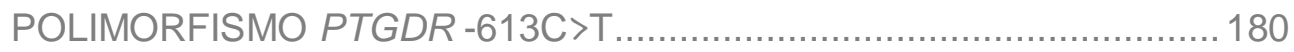

ESTUDIO DE HAPLOTIPOS ............................................................. 181

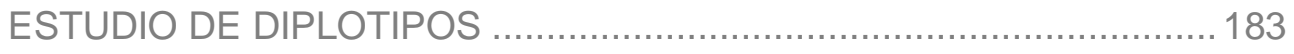

CONSIDERACIONES DE LOS ESTUDIOS DE ASOCIACIÓN.................185

6.2 Estudio funcional del promotor de PTGDR............. 187

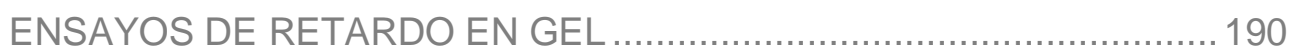

ANÁLISIS IN SILICO DEL PROMOTOR DE PTGDR E IDENTIFICACIÓN DE LOS COMPLEJOS ADN:PROTEÍNA 
6.3 Implicaciones en la terapia del asma ......................198

7. CONCLVSIONES.........................................203

8. APENDICE ................................................207

9. BíBLÍOGRAFÍA ............................................213 


\section{ABREVIATVRAS}

A: Adenina

aa: Aminoácido

AC: Adenilato ciclasa

ADAM33: A Disintegrin And Metalloprotease 33 (Desintegrina y metaloproteasa 33)

ADRß2: $\beta 2$ adrenergic receptor (Receptor $\beta 2$ adrenérgico)

ADN: Ácido desoxirribonucleico

ADNds: ADN de doble cadena

ADNss: ADN de cadena sencilla

AERD: Enfermedad respiratoria exacerbada por aspirina

AINE: Antiinflamatorio no esteroideo

ALOX5: 5-lipooxigenasa del ácido Araquidónico

AMPc: Adenosín monofosfato cíclico

AMPS: Persulfato amónico

Arg: Arginina

ARN: Ácido ribonucleico

ARNm: ARN mensajero

Asn: Asparragina

ATP: Adenosín trifosfato

ATS: American Thoracic Society (Sociedad Torácica Americana)

Aval: Anabaena variabilis

BsoBI: Bacillus stearothermophilus

C: Citosina

$\mathrm{Ca}^{2+}$ : lón calcio 
CCL-1: Chemokine (C-C motif) ligand 1 (Primer ligando de la familia CC de las quimiocinas)

CD: Cluster of differentiation (Agrupación de diferenciación)

cm: centímetro

$\mathrm{CoCl}_{2}$ : Cloruro de cobalto

COX: Ciclooxigenasa

CRTH2: Chemoattractant receptor-homologous molecule expressed on $\mathrm{TH} 2$ (molécula homóloga de receptor quimiotáctico extresada en células Th2)

CSPD: 3-(4-metoxi-espiro[1,2-dioxetano-3,2'-(5'-cloro)triciclo[3.3.1.1 $1^{3,7}$ decan]-4il] fenil fosfato.

CVC: Coeficiente de validación cruzada

CYFIP2: Proteína 2 que interacciona con la proteína citoplasmática FMRP

CYP: Citocromo P450

Da: Dalton

DIG: Digoxigenina

DIG-11-ddUTP: Digoxina-dideoxy-uracil-trifosfato

dNTPs: Desoxirribonucleotidos trifosfato

DPP10: Dipeptidil-dipeptidasa 10

DTT: Ditiotreitol

EAACI: The European Academy of Allergy and Clinical Immunology (Academia Europea de Alergia e Inmunología Clínica)

EDTA: Ácido etilendiaminotetraacético

EP: Receptor de la prostaglandina $\mathrm{E}_{2}$

EPOC: Enfermedad pulmonar obstructiva crónica

FA: Fosfatasa alcalina

FceR (FCER): Receptor de la fracción constante de lgE

$\mathrm{FEV}_{1}$ : Volumen espirado máximo en el primer segundo de la espiración forzada FGF-2: Factor de crecimiento de fibroblastos 2 
FLG: Filagrina

fmol: Femtomol

FMRP: Citoplasmic fragile $X$ mental retardation protein (Proteína asociada al retraso mental ligado al $\mathrm{X}$ frágil)

FPRP: Probabilidad de emitir un resultado positivo falso

FVC: Capacidad vital forzada

g: gravedad

G: Guanina

GATA 3: Factor de transcripción 3 de la familia GATA

GINA: Global Initiative for Asthma (Estrategia Global para el Asma)

Gli: Glicina

Gln: Glutamina

Glu: Glutámico

GM-CSF: Factor de estimulación de colonias de granulocitos y macrófagos

GR: Receptor intracelular de glucocorticoides

GRE: Glucocorticosteroid response element (Elemento de respuesta a los corticoides)

CRHR1: Receptor de corticotropina

GRPA: Receptor acoplado a proteína GGST: Glutation-S-transferasa

GWA: Genome Wide Association analysis (Estudios de asociación de todo el genoma)

HAT: Acetiltransferasa de histonas

$\mathrm{HCl}$ : Ácido clorhídrico

HEPES: Ácido 4-(2-hidroxietil)-1- piperazineetanosulfónico

HLA: Antígeno leucocitario humano

HRB: Hiperreactividad Bronquial

HRP: Horseradish peroxidase (peroxidasa del rábano picante)

IFN: Interferón 
lgE: Inmunoglobulina $E$

IgG: Inmunoglobulina G

IL: Interleucina

IL-4RA: Subunidad A del receptor de IL-4

IL-1RN: Receptor de IL-1

iNOS: Óxido nítrico sintasa inducible

IP: Receptor de prostaglandina $I_{2}$

ISAAC: International Study of Asthma and Allergies in Childhood (Estudio Internacional del Asma y Alergia en la Infancia)

к: Cadena ligera kappa

$\mathrm{Kb}$ : Kilobase

$\mathrm{KCl}$ : Cloruro de potasio

kDa: Kilodalton

kU: Kilounidad

kV: Kilovoltio

LBA: Lavado broncoalveolar

LD: Desequilibrio de ligamiento

Lt: Leucotrienos

LT-A: Linfotoxina alfa

LTC4: Leucotrieno C4

LTC4S: Sintasa de LTC4

Lys: Lisina

M: Molar

MDC: Macrophage-derived chemokine (Quimiocina derivadas del macrófago)

mg: miligramo

$\mathrm{Mg}^{2+}$ : lón magnesio

$\mathrm{MgCl}_{2}$ : Cloruro magnésico 
MHC-II: Major Histocompatibility Complex Clase II (Complejo Principal de Histocompatibilidad de Clase II)

MPO: Mieloperoxidasa

$\mathrm{NaCl}$ : Cloruro potásico

NF-KB: Factor nuclear kappa beta

$\left(\mathrm{NH}_{4}\right)_{2} \mathrm{SO}_{4}$ : Sulfato de amonio

NK: Natural killer

NO: Óxido nítrico

NR3C1: Nuclear Receptor Subfamily 3, Group C, Member 1 (Subfamilia 3 de receptores nucleares, grupo $\mathrm{C}$, miembro 1)

$\mathrm{O}_{2}^{-}$: Radical superóxido

$\mathrm{OH}^{-}$: Radical hidroxilo

OR: Odds Ratio Razón de odds

OVA: Ovoalbúmina

PAF: Factor activador plaquetario

$\mathrm{Pb}$ : Pares de bases

$\mathrm{PC}_{20}$ : Concentración de metacolina en $\mathrm{mg} / \mathrm{ml}$ que produce una caída del $\mathrm{FEV}$ del $20 \%$

PCR: Polymerase Chain Reaction (Reacción en cadena de la polimerasa)

$\mathrm{PGD}_{2}$ : Prostaglandina D2

PGDS: Sintasa de la prostaglandina D2

$\mathrm{PGE}_{2:}$ Prostaglandina E2

$\mathrm{PGG}_{2:}$ Prostaglandina G2

$\mathrm{PGH}_{2:}$ Prostaglandina $\mathrm{H} 2$

PGT: Transportador de prostaglandinas

$\mathrm{pH}$ : pondus Hydrogenium

PHD: Plant Homeodomain (Homeodominio de plantas)

PHF11: PHD finger protein 1 (proteína 1 en dedo PHD) 
Pi: base pirimidínica

PKA: Proteína quinasa A

PKC: Proteína quinasa C

PMF: Peptide Mass Fingerprint (Huella peptídica)

pmol: picomol

PPAR: Receptor gamma activador de la proliferación peroxisomal

Pst I: Providencia stuartii

PTGDR (DP): Receptor de prostaglandina D2

Pu: base púrica

PVDF: Polyvinylidene difluoride (Polifluoruro de vinilideno)

QTLs: Quantitative trait loci (loci con efecto cuantitativo)

RFLP: Restriction Fragment Length Polymorphism (Polimorfismos de la longitud de los fragmentos de restricción)

r.p.m.: revoluciones por minuto

SDS: Dodecilsulfato sódico

Ser: Serina

SLCO2B1: Transportador de aniones 2B1

SNC: Sistema nervioso central

SNP: Single-Nucleotide Polymorphism (Polimorfismo de un único nucleótido)

SPINK5: Serine Protease Inhibitor Kazal-type 5 (Inhibidor Kazal tipo 5 de la serinproteasa)

SSP-PCR: Sequence-Specific-Primer PCR (Reacción en cadena de la polimerasa con cebadores específicos de secuencia)

STAT: Signal Transducer and Activator of Transcription (Transductor y activador de la transmisión de señal)

T: Timina

TAE: tampón Tris-Acético-EDTA

TARC: Quimiocinas reguladas y activadas en el tiempo 
TBA: Coeficiente de Viabilidad del Modelo

TBE: Tris-Borato-EDTA

TBS: Tris Buffer Salino

TEMED: TetraMetilEtilenDiamida

TEN=STE: Tris-EDTA-NaCl

TGF- $\beta$ ): Transforming growth factor beta (Factor $\beta$ Transformante del Crecimiento)

Th: Thelper (T colaborador)

Thr: Treonina

TLR: Toll-like receptor (Receptor de tipo "toll")

TNF: Tumor necrosis factor (Factor de necrosis tumoral)

TP: Receptor de tromboxano $\mathrm{A}_{2}$

TSLP: Thymic stromal lymphopoietin (Linfopoyetina tímica estromal)

TXA $_{2}$ : Tromboxano $A_{2}$

U: Unidades enzimáticas

UV: Ultravioleta

V: Voltio

V-CAM-1: Molécula de adhesión vascular tipo I

VDR: Receptor de la vitamina D

VEGF: Factor de crecimiento vascular endotelial

VLA-4: Very Late Antigen 4 (Antígeno muy tardío tipo 4)

VNTR: Variable Number Tandem Repeat (Número variable de repeticiones en tándem)

VRS: Virus Respiratorio Sincitial

$\chi^{2}$ : Chi cuadrado

$\mathrm{Zn}^{2+}$ : lón zinc 



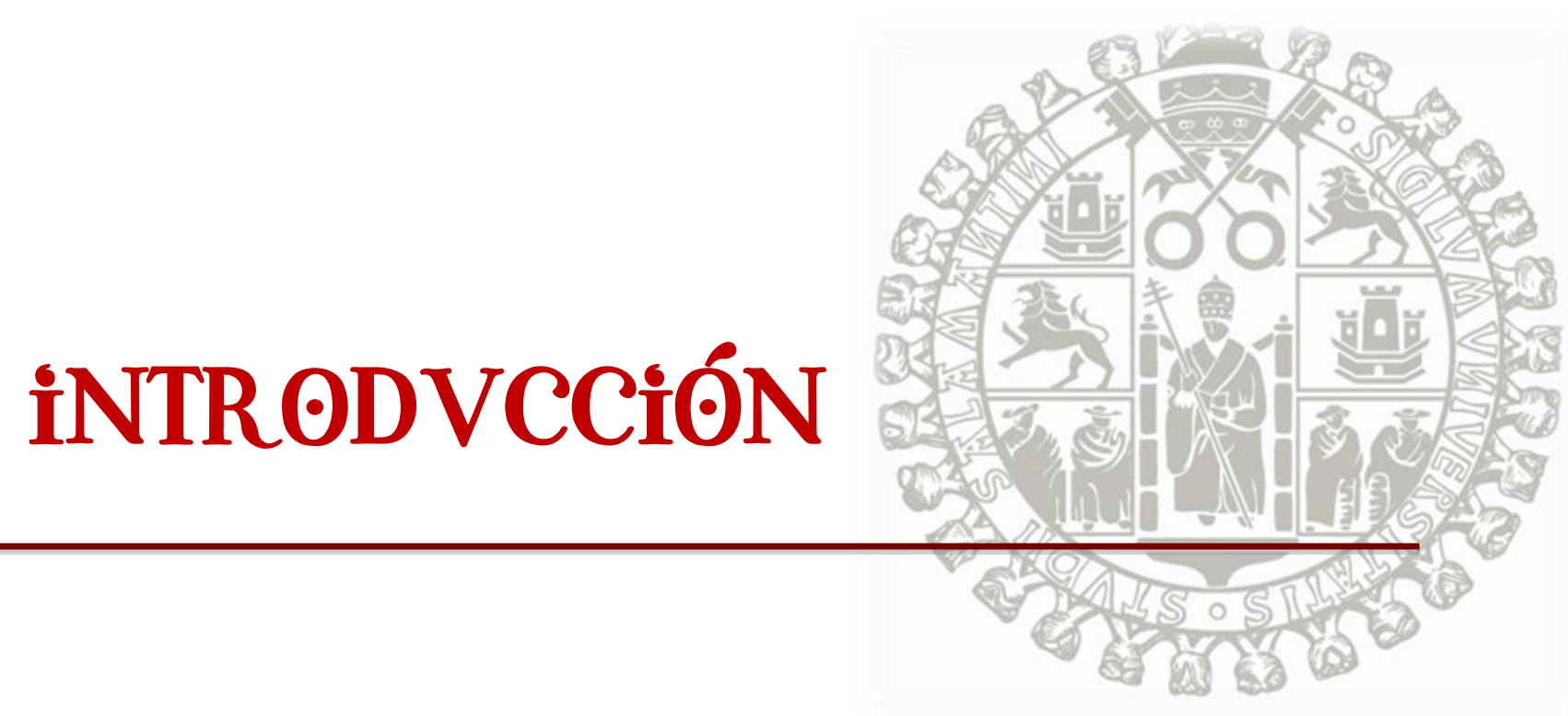





\section{INTRODVCCí́N}

\subsection{DEFíNíCí́N}

En la Grecia Clásica fue utilizada por primera vez la palabra asma, por el propio Homero en la llíada, para describir dos episodios caracterizados por sudoración y dificultad respiratoria. Posteriormente fue empleada por Hipócrates para describir una enfermedad intolerante mucho más grave que una disnea simple [1] y es que el término asma deriva de la palabra griega ä́ $\theta \mu \alpha$, y del latín asthma, que significa jadeo o ahogo [2].

Conceptualmente, el término asma ha sido sometido a continuos cambios a lo largo del tiempo por la complejidad y el desconocimiento de la patología a la que pone nombre. En definitiva, su definición se ha modificado a medida que se han ido caracterizando los mecanismos fisiopatológicos implicados en ella. En la actualidad, la Estrategia Global para el Asma (GINA) define el asma como "una inflamación crónica de las vías respiratorias asociada a hiperreactividad bronquial, que cursa con episodios recurrentes de sibilancias, disnea, opresión torácica y tos, principalmente por la noche o de madrugada. Estos episodios normalmente se encuentran asociados a un trastorno ventilatorio obstructivo, total o parcialmente reversible, de forma espontánea o con tratamiento farmacológico" [3]. Es un síndrome complejo, con un fenotipo heterogéneo, cuya etiología multifactorial se ha atribuido a las interacciones entre diversos genes y entre éstos y el medio ambiente [4]. 


\subsection{EPIDEMiOLOGíA}

El asma es una de las enfermedades crónicas más comunes en el mundo y la enfermedad crónica más frecuente que afecta a niños y adultos jóvenes [5]. Se estima que hasta 300 millones de personas padecen asma en el mundo. Está presente en todos los países, pero no en la misma medida; su prevalencia mundial oscila entre el 1 y el 18\% (figura 1) [5].

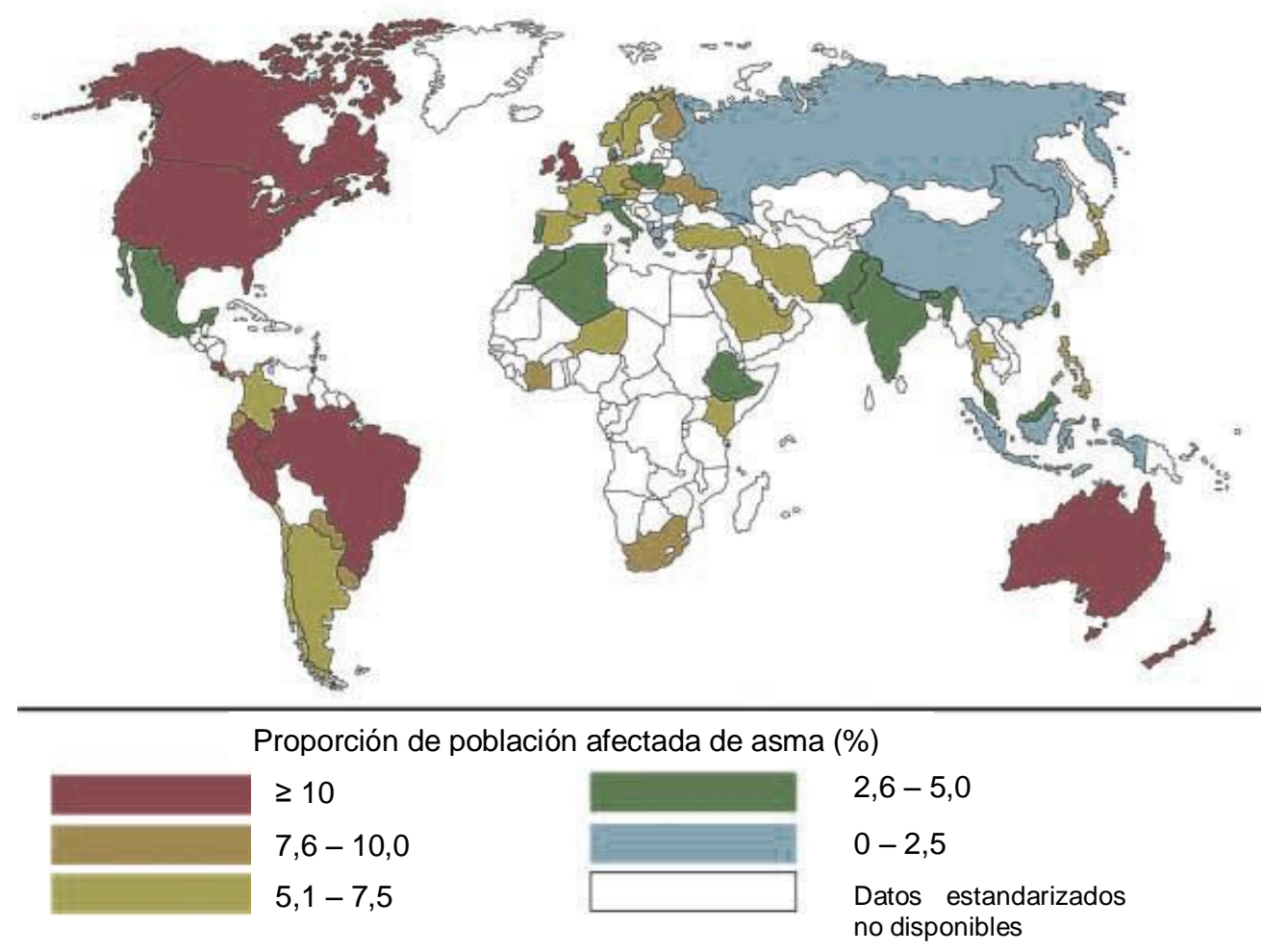

Figura 1. Mapa mundial de la prevalencia del asma [5].

Esta enfermedad es el objetivo de diversas intervenciones clínicas y de salud pública [6]. El importante coste económico que supone incluye tanto gastos de hospitalización y tratamientos farmacológicos, como costes indirectos por absentismo laboral, y muerte prematura [7]. Tanto la morbilidad como la mortalidad por asma son relevantes, especialmente en los niños [6]. Aunque en 
muchos países la información sobre la mortalidad del asma no es fiable, se estima que al año fallecen 250.000 personas a causa de esta enfermedad [5]. Los países con las tasas de mortalidad más elevadas son aquellos en los que no se dispone de una terapia adecuada. Sin embargo, los planes de tratamiento del asma han reducido la mortalidad asociada y su gravedad en los países donde se han aplicado [6].

En la fase I del Estudio Internacional sobre Asma y Alergia en la Infancia se realizaron comparaciones en distintas partes del mundo sobre la prevalencia de los síntomas de asma [8]. Posteriormente, en la fase III del mismo, se repitió la encuesta de la fase inicial con el fin de evaluar los cambios de prevalencia a lo largo del tiempo [9]. Los resultados mostraron una disminución de las diferencias en la prevalencia de los síntomas de asma a nivel internacional (figura 2). En algunos países, especialmente en los de habla inglesa, la prevalencia no había aumentado, sino que incluso había disminuido, mientras que se detectó un notable incremento de la prevalencia de los síntomas en los países latinoamericanos. Por otra parte, se observó un modesto aumento en algunos puntos de Asia, entre ellos China, y aumentos más importantes en distintos países africanos como Marruecos [9].

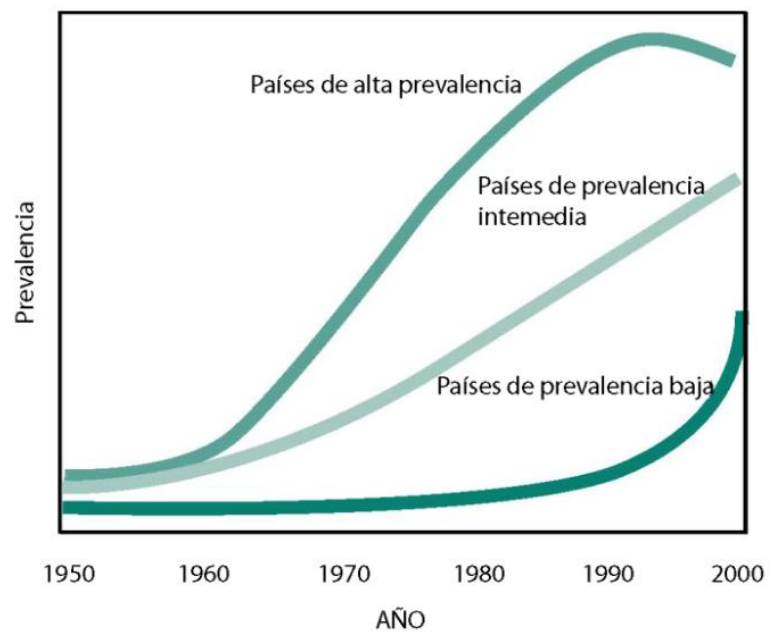

Figura 2. Tendencias de la prevalencia del asma [6]. 


\subsection{CARACTER ÍSTICAS CLINICAS}

Las características clínicas del asma son síntomas como tos, sibilancias, disnea y opresión torácica; la presencia de hiperreactividad bronquial (HRB) y/o, en muchos casos, la presencia de atopia. Sin embargo, no sólo existe un amplio abanico fenotípico de esta enfermedad, es decir, diferentes formas en que se presenta; sino que, además, el asma diagnosticada en la clínica habitual representa un grupo heterogéneo de trastornos con muchas posibles causas subyacentes.

\section{SÍNTOMAS CLÍNíCOS:}

En el Estudio Internacional sobre Asma y Alergia en la Infancia (ISAAC) [8], los síntomas del asma se objetivan mediante la utilización de cuestionarios estandarizados y validados. Los principales síntomas que se estudian son [10]:

TOS: Constituye uno de los síntomas clásicos del asma bronquial. Generalmente, se trata de una tos muy repetitiva que, con frecuencia, se incrementa por la noche y en determinadas situaciones o ambientes. La tos puede aparecer en distintas fases de la crisis asmática: al inicio de los síntomas es una tos seca o con escasa expectoración debida fundamentalmente al estrechamiento de las vías respiratorias y a la irritación de receptores vagales por la presencia de mediadores inflamatorios. En fases más avanzadas, como en el caso de la fase de resolución, se debe más a la mucosidad que obstruye las vías respiratorias, y se asocia a la expectoración.

DíSNEA: El término proviene del griego $\delta v \sigma$ que significa dificultoso, doloroso y $\pi v o ı$ que significa respiración; es la sensación de falta de 
aire o respiración dificultosa [2]. Entre los distintos mecanismos fisiológicos causantes de la disnea se encuentran el aumento del trabajo de la musculatura, que intenta mantener el flujo de aire a pesar de la obstrucción, la disminución de la distensibilidad pulmonar agravada por la hiperinsuflación, como ocurre también en la enfermedad pulmonar obstructiva crónica (EPOC), y la estimulación de receptores irritantes vagales.

SíBíLANCíAS: La palabra sibilancia proviene del verbo latín sībilā(re) que significa silbar [2]. Las sibilancias son los ruidos que se producen por la entrada o salida de aire debidos al estrechamiento interno de las vías respiratorias. De los signos típicos del asma, es el que mejor se asocia al diagnóstico de asma, el más característico.

OPRESİ́N TORÁCiCA: Aparece con mucha frecuencia, de hecho es el más referido por los pacientes aunque lo describan de formas distintas. Se suele describir como si no se pudiese acabar de realizar una inspiración profunda, sensación debida a la limitación del flujo aéreo y a la irritación de receptores vagales pulmonares.

\section{HiPERREACTİVİDAD BRONQVİAL}

La hiperreactividad bronquial se considera una característica universal del asma en el ser humano [11], pero no exclusiva, puesto que también puede presentarse en otras patologías como la rinitis alérgica, la fibrosis quística y la enfermedad pulmonar obstructiva crónica, entre otras [12]. Se describe como una sensibilidad anormal de las vías respiratorias, que se expresa como un aumento de la obstrucción al flujo aéreo tras la exposición a estímulos directos o 
indirectos sobre el músculo liso bronquial, los cuales provocan la liberación de mediadores inflamatorios [13].

\section{ATOPiA}

El término atopia se emplea en referencia a las enfermedades alérgicas. Deriva de la palabra griega óromía compuesta a su vez por las palabras $\alpha$ (sin) y то́тоо (lugar) y por tanto su significado es fuera de lugar [2]. Se define como una reacción inmune inflamatoria exagerada e inapropiada mediada por la inmunoglobulina $E(\lg E)$, en cuanto a que se dirige contra un antígeno común y relativamente inocuo para el organismo [14]. Inicialmente fue utilizada por Coca y Cooke en 1923 para describir las enfermedades alérgicas como la dermatitis atópica, la rinitis alérgica o el asma alérgica, las cuales muestran una predisposición genética y en las que intervienen anticuerpos de tipo lgE (figura 3). El diagnóstico de la atopia se determina mediante la positividad de las pruebas cutáneas intraepidérmicas o prick realizadas con una batería de aeroalérgenos.

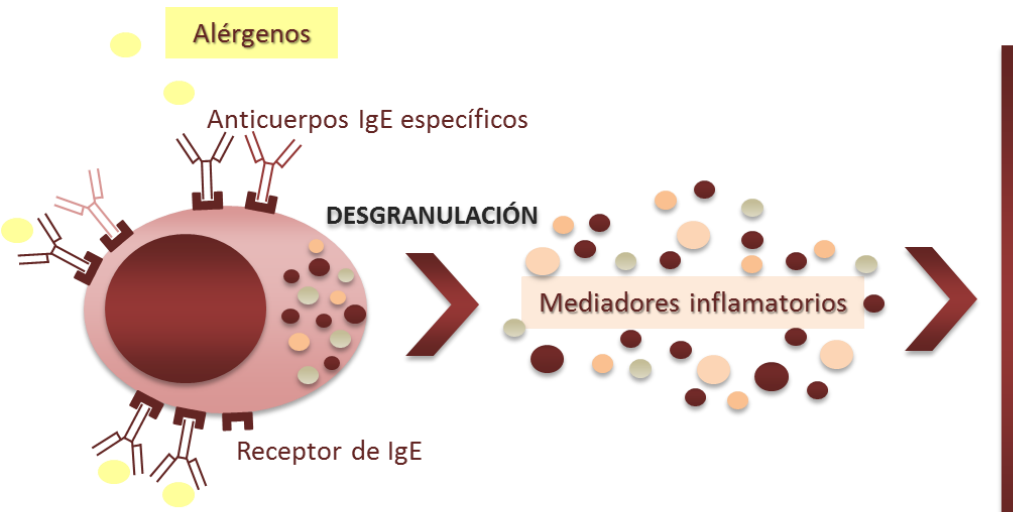

Células del músculo liso

Vasos sanguineos

Glándulas mucosas

Plaquetas

Terminaciones nerviosas

Eosinófilos

Mastocito sensibilizado

Figura 3. Secuencia de mecanismos desencadenados por los anticuerpos IgE específicos tras la exposición al alérgeno. 
La mayoría de los individuos asmáticos son a su vez atópicos, es decir presentan síntomas con la exposición a determinados aeroalérgenos, o manifestaciones subclínicas detectadas por las citadas pruebas cutáneas 0 niveles séricos elevados de lgE específica [15].

\section{ASMA ATఠ́PICA/NO ATÓPícA}

En el asma atópica, la respuesta inflamatoria se asocia con una sensibilización frente a los alérgenos y, en general, a una elevación de los niveles séricos totales de $\lg \mathrm{E}$. A raíz de la interacción del alérgeno con la $\lg \mathrm{E}$ específica en la superficie del mastocito, éste se activa y libera distintos mediadores, citocinas y quimiocinas, que provocan un incremento en la permeabilidad vascular, la contracción del músculo liso bronquial, la activación de los linfocitos T y el reclutamiento de células como eosinófilos y basófilos; los cuales, junto a los linfocitos $\mathrm{T}$ son responsables de la respuesta tardía a la exposición con los alérgenos, que se acompaña de hiperreactividad bronquial (figura 3).

En el asma no atópica no se encuentra una lgE específica dirigida frente a un alérgeno o antígeno, los niveles séricos de $\lg E$ total se suelen mantener dentro del rango de la normalidad y no se produce respuesta frente a alérgenos exógenos. En este caso los eosinófilos desempeñan una función muy importante en la reacción inflamatoria a través de la liberación de sus mediadores proinflamatorios. 


\subsection{DíAGN@́STíCO}

El diagnóstico del asma es un diagnóstico clínico y funcional; se basa en una anamnesis dirigida a determinar los síntomas característicos de la enfermedad (tos, sibilancias, disnea, dolor u opresión torácica) y las diferentes circunstancias de la misma. Sin embargo, algunos de estos síntomas son compartidos por otras enfermedades, lo cual hace necesario una valoración conjunta de estos datos para una mayor eficacia diagnóstica que descarte otras posibles causas [3].

DíAGNÓSTíCO CLíNíCO: El diagnóstico clínico del asma bronquial es posible gracias a la exploración física del paciente y a la información recogida en su historia clínica. La historia clínica recoge tanto los antecedentes personales como los familiares, además del conjunto de signos y síntomas que presenta. La forma más habitual de presentación de los síntomas es de forma episódica.

DíAGN@́STíCO FVNCiONAL: Para el diagnóstico funcional de la obstrucción pulmonar y de su reversibilidad espontánea o con tratamiento se utilizan una serie de pruebas como son la espirometría, la prueba de broncodilatación y las pruebas de provocación bronquial.

- ESPíRøMETRía BASAL: Se cuantifican los volúmenes pulmonares estáticos y volúmenes y flujos pulmonares dinámicos con el fin de valorar la función pulmonar; que se encuentra disminuida con un patrón obstructivo.

- PRVEBA DE BRONCODílATACí̂N: Se estudia la reversibilidad de la obstrucción de la vía respiratoria característica del asma. Se valora la función pulmonar en condiciones basales y tras la administración de un broncodilatador (agonista beta-adrenérgico o anticolinérgico) mediante 
espirometrías. Si dicha función se recupera por encima de un mínimo establecido, la prueba broncodilatadora es positiva, y es diagnóstica de asma. Sin embargo, una prueba negativa no lo descarta.

- PRVEBA DE PROVOCACIÓN BRONQVíAL: El diagnóstico de hiperreactividad bronquial se puede llevar a cabo mediante una prueba de provocación con metacolina, un broncoconstrictor colinérgico. Se determina la sensibilidad de las vías respiratorias a partir de la dosis de fármaco inhalado que provoca una determinada disminución de la función pulmonar. También se puede realizar con histamina o con estimulantes indirectos, como la adenosina.

En el caso de pacientes que refieren los síntomas tras la realización de ejercicio físico, es el test de ejercicio la prueba de elección para el diagnóstico de la hiperreactividad bronquial. Dicho test consiste en la comparación entre una espirometría basal y otra espirometría tras realizar una carrera libre, en cinta rodante o bicicleta estática. En cuanto se producen los síntomas se interrumpe el ejercicio, y una vez confirmada la obstrucción, se administra un broncodilatador y se comprueba la reversibilidad de dicha obstrucción.

Finalmente, existe la posibilidad de utilizar agentes específicos para el estudio etiológico del asma; mediante la exposición controlada a una determinada sustancia que puede ser responsable de la aparición de la sintomatología.

DÍAGN@́STíC○ DíFERENCIAL: Se deben descartar otras enfermedades que pueden cursar con sibilancias, disnea y/o tos. La tos procedente de las vías aéreas superiores y el síndrome de hiperventilación, entre otros, pueden ser confundidos con relativa frecuencia con el asma. La clave del diagnóstico diferencial es la presentación clínica de la enfermedad, su coincidencia con 
factores desencadenantes y la demostración de la disfunción pulmonar en términos de obstrucción reversible de las vías respiratorias y/o hiperreactividad bronquial.

DíAGNÓSTíCo ETíOLÓGíco: El diagnóstico etiológico se basa en la búsqueda de la causa del asma. Se realizan pruebas intraepidérmicas con una batería estandarizada de aeroalérgenos y se determinan los niveles de IgE total y también de anticuerpos IgE específicos frente a alguno de los alérgenos. A veces es necesario recurrir a una provocación bronquial.

\subsection{ETIOPATOGENíA}

En la propia definición del asma se hace referencia al proceso inflamatorio crónico que subyace a esta patología, así como a la característica obstrucción al flujo aéreo y la capacidad de respuesta de la vía respiratoria. Dicha alteración inflamatoria implica la liberación de mediadores proinflamatorios de los mastocitos [16], la activación de linfocitos Th2 (“T helper-2": linfocitos T colaboradores de tipo 2), macrófagos, y el reclutamiento y desgranulación de eosinófilos. Estos procesos que acontecen en las vías respiratorias no sólo causan obstrucción al flujo aéreo, también aumentan la hiperreactividad de las propias vías. Por otro lado, la progresión de la inflamación produce una remodelación de las vías respiratorias, que puede dar lugar a alteraciones permanentes en su estructura de forma que los eventos obstructivos se hagan más o menos irreversibles (figura 4). El estudio de los mecanismos fisiopatológicos y su regulación a nivel genético y ambiental proporciona una visión amplia de la enfermedad y plantea nuevas posibilidades en el tratamiento. 

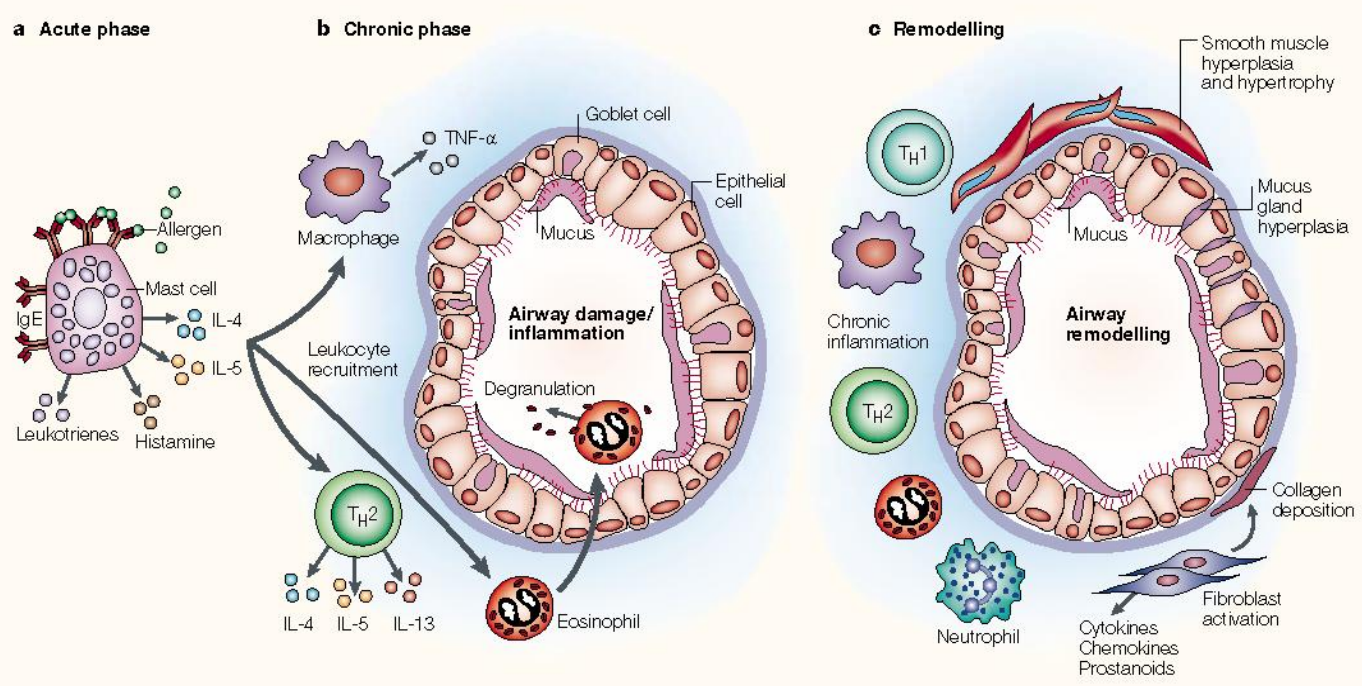

Figura 4. Esquema de la secuencia de eventos desencadenados a partir de la exposición a un alérgeno. Inflamación y daños en las vías respiratorias hasta una posible remodelación del tejido bronquial [17].

\section{INFLAMACí́N DE LAS VÍAS RESPIRATORIAS}

La inflamación de las vías respiratorias es una característica común y persistente en el asma, independientemente de si el desencadenante es alérgico o no. Los efectos que causa son más pronunciados en la zona intermedia del árbol bronquial, aunque afectan a todo el aparato respiratorio. El desarrollo y mantenimiento de este estado inflamatorio es el producto de la interacción de un conjunto de tipos celulares a través de una gran variedad de mediadores inflamatorios (figura 5). Entre las células que participan en este proceso están algunas propias del tejido como los macrófagos alveolares, células dendríticas, epiteliales, endoteliales, y del musculo liso; y otras que son reclutadas a la mucosa bronquial como los eosinófilos, mastocitos, linfocitos T y neutrófilos. 


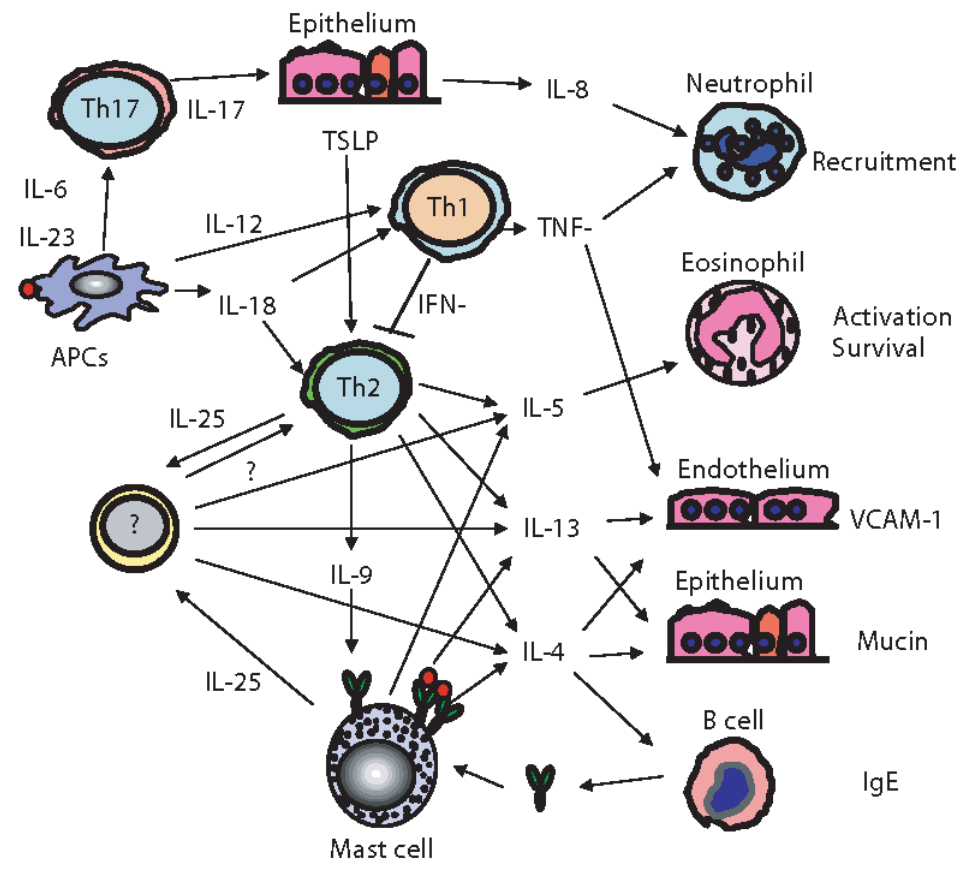

Figura 5. Esquema de los mediadores y reguladores del proceso inflamatorio en el asma $(\mathrm{APCs}=$ Células Presentadoras de Antígeno; $\mathrm{VCAM}-1=$ Molécula de Adhesión Vascular 1; TSLP= Linfopoyetina Estromal Tímica) [18].

\section{MASTOCITOS}

Son células determinantes en la inflamación alérgica y desempeñan un papel fundamental en la sintomatología del asma, particularmente en la fase inmediata [19]. Se caracterizan por poseer receptores de alta afinidad para IgE (FcعRI) en su superficie, al igual que los basófilos. Su activación, específica de antígeno, desencadena la liberación de mediadores que originan en el asma la respuesta broncoconstrictora característica y es probable que también sean responsables de iniciar esta respuesta frente al resto de estímulos desencadenantes de la patología. En la respuesta inicial a la presencia del alérgeno, estas células liberan de forma masiva un conjunto de mediadores vasoactivos como la histamina, la prostaglandina $D_{2}\left(P G D_{2}\right)$ y los leucotrienos cisteinílicos (LTC4, LTD4, y LTE4); capaces de inducir dicha broncoconstricción, 
así como un aumento de la permeabilidad vascular y de la secreción mucosa. Además, sintetizan y liberan determinadas citocinas proinflamatorias como las interleucinas (IL) IL-4, IL-5 e IL-13 que regulan la síntesis de lgE y la activación de eosinófilos; y otras de efecto profibrótico como el factor de crecimiento transformante $\beta$ (TGF- $\beta$ ) y el factor de crecimiento de los fibroblastos, FGF-2 [20] (figura 6).

Por otro lado, se produce un reclutamiento de los mastocitos por el músculo liso bronquial que podría estar facilitando la interacción entre estas células. De hecho se ha planteado la posibilidad de que los mastocitos contribuyan al desarrollo de la hipertrofia y la hiperplasia del músculo liso expresada en la hiperreactividad bronquial, y la obstrucción variable al flujo aéreo [21].

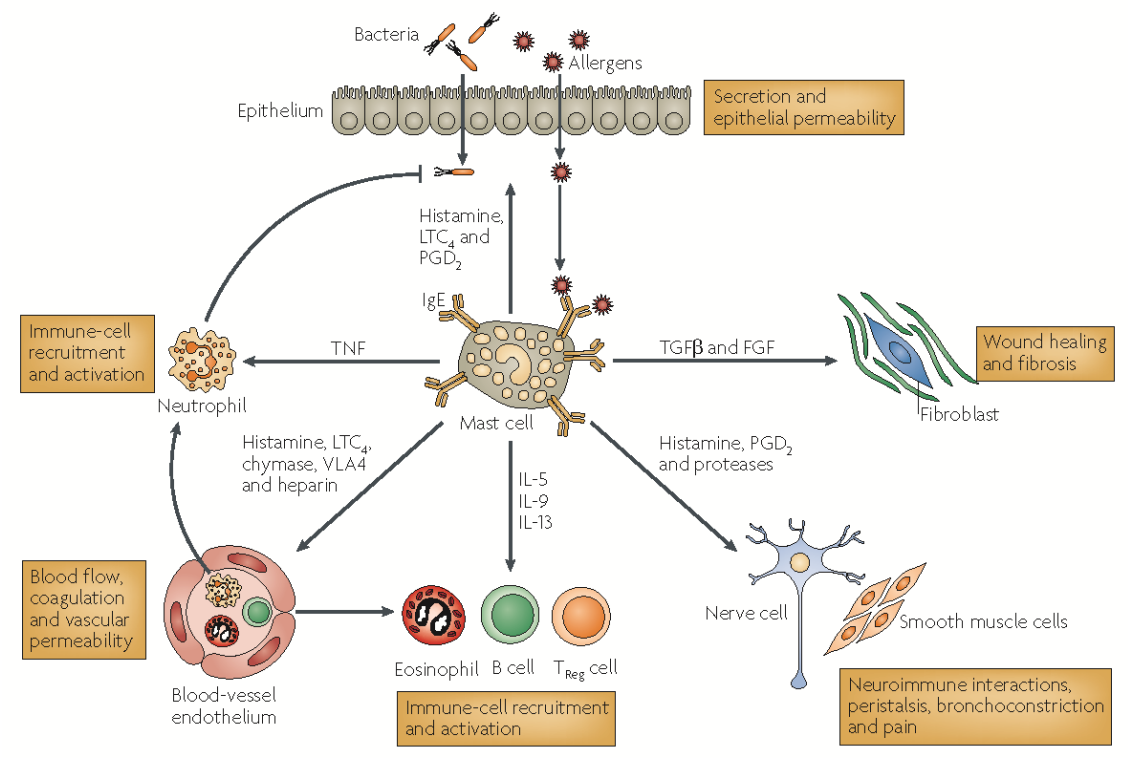

Figura 6. Representación del papel del mastocito en la respuesta inflamatoria [22].

\section{EOSíNǴFíLOS}

En la mayoría de los fenotipos del asma, existe un aumento de los eosinófilos en los tejidos, sangre y médula ósea; incremento que se asocia con 
la gravedad de la enfermedad. Su tasa de apoptosis disminuye significativamente en la mucosa bronquial de los pacientes asmáticos respecto a los individuos sanos, y estos valores se correlacionan inversamente con la gravedad clínica del asma [23].

La infiltración de las vías respiratorias por eosinófilos es una característica de la inflamación alérgica, son las células predominantes en el típico proceso crónico de la fase tardía de la respuesta alérgica. Son reclutados al epitelio bronquial gracias a la interacción entre moléculas de adhesión expresadas en él, como VCAM-1, y las moléculas de integrina VLA-4 (Very Late Antigen 4, Antígeno 4 de expresión muy tardía), presentes en la superficie de los eosinófilos. La migración puede deberse a estímulos quimiotácticos de mediadores lipídicos como los leucotrienos, el factor activador plaquetario (PAF), o quimiocinas como RANTES o las eotaxinas 1-3.

Son capaces de lesionar la mucosa respiratoria y las terminaciones nerviosas asociadasa través de mediadores proinflamatorios, entre ellos la proteína catiónica de los eosinófilos, la proteína básica principal, la peroxidasa de los eosinófilos, e intermediarios de compuestos reactivos con el oxígeno [24]. También liberan el factor estimulador de colonias (GM-CSF), LTC4 y otras citocinas. Además, la inflamación eosinofílica se asocia con un aumento de los niveles de expresión de TGF- $\beta$ y del espesor de la membrana basal; marcadores de remodelado de las vías respiratorias (figura 7) [25]. Del mismo modo, a través de interacciones con los nervios parasimpáticos y la liberación de acetilcolina pueden participar en la hiperreactividad bronquial característica del asma [26]. Otros estudios han sugerido una función inmunomoduladora de los eosinófilos que intervendrían en el equilibrio entre las poblaciones linfocitarias Th1 y Th2 a través de la liberación de citocinas como IL-4, IL-13, IL-12 y el interferón (IFN) y [27]. 


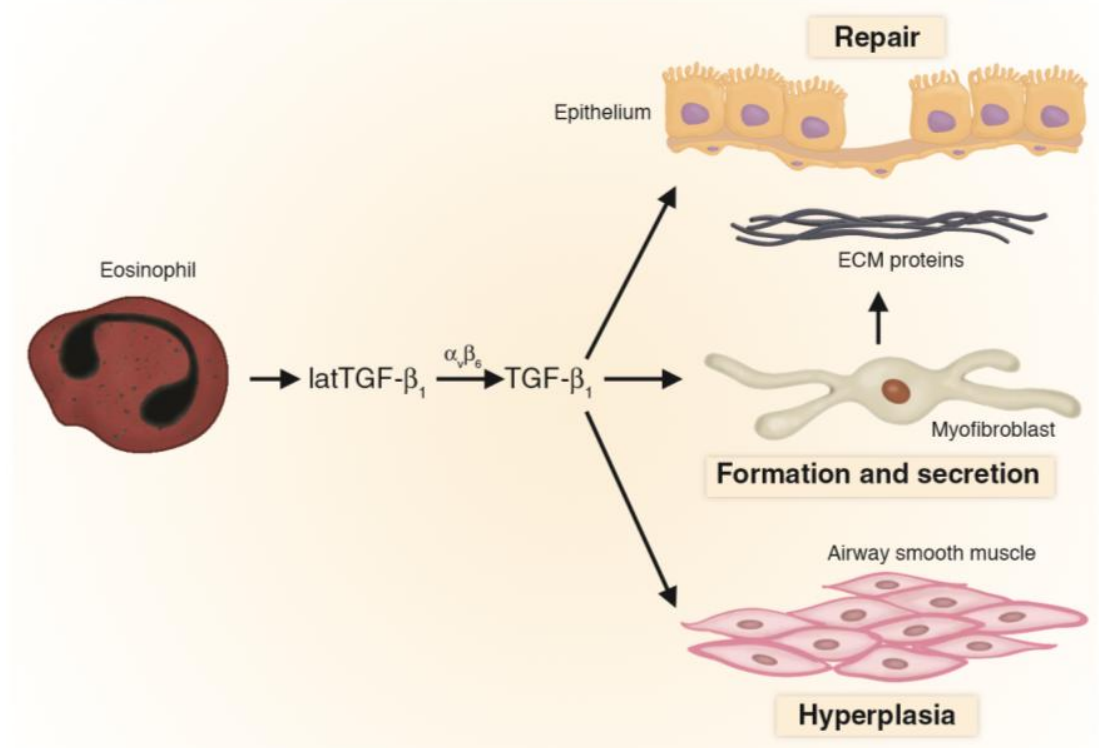

Figura 7. Producción de TGF- $\beta_{1}$ por los eosinófilos y su función en la remodelación de las vías respiratorias. Este factor de crecimiento secretado en forma latente (latTGF- $\beta_{1}$ ) es activado por la integrina epitelial $\alpha_{5} \beta_{6}$ y de esta forma induce la formación de miofibroblastos secretores de las proteínas de la matriz extracelular y estimula la hiperplasia del músculo liso respiratorio [28].

\section{LINNFCITTOS T}

En las biopsias de mucosa obtenidas durante un episodio de asma inducida por la inhalación de alérgeno se describe la presencia de linfocitos, muchos de los cuales expresan marcadores de activación en su superficie [16]. El grado de activación de estas células y la expresión en su superficie de CD25, receptor de la citocina IL-2 reflejan la gravedad del asma [29].

El papel que desempeñan los linfocitos $T$ en el asma es el de integrar y mantener en la respuesta inflamatoria, la activación de los linfocitos B y los mastocitos, la producción de lgE, el aumento de la expresión de moléculas de adhesión como VCAM-1 y el reclutamiento de eosinófilos; todo ello a través de citocinas de tipo Th2 como IL-4, IL-5, IL-9 e IL-13 [30] (figura 8). Dentro de este patrón de citocinas Th2, la IL-4 participa en el cambio de isotipo hacia lgE, así 
como la IL-13. Mientras que la IL-5 está implicada en la diferenciación y supervivencia de los eosinófilos. La IL-9 que originalmente se describió como un factor de crecimiento de los mastocitos, también interviene en la activación de estas células, estimulando la producción de proteasas [14].

El desequilibrio entre las respuestas Th1 y Th2 se ha observado en los pacientes asmáticos con o sin componente alérgico, de manera que esta desviación inapropiada hacia la secreción de citocinas de tipo Th2 se ha planteado como responsable del fenotipo característico de las enfermedades alérgicas y, a raíz de los modelos animales, se ha propuesto que la inflamación alérgica es un mecanismo mediado por las células Th2 [16].

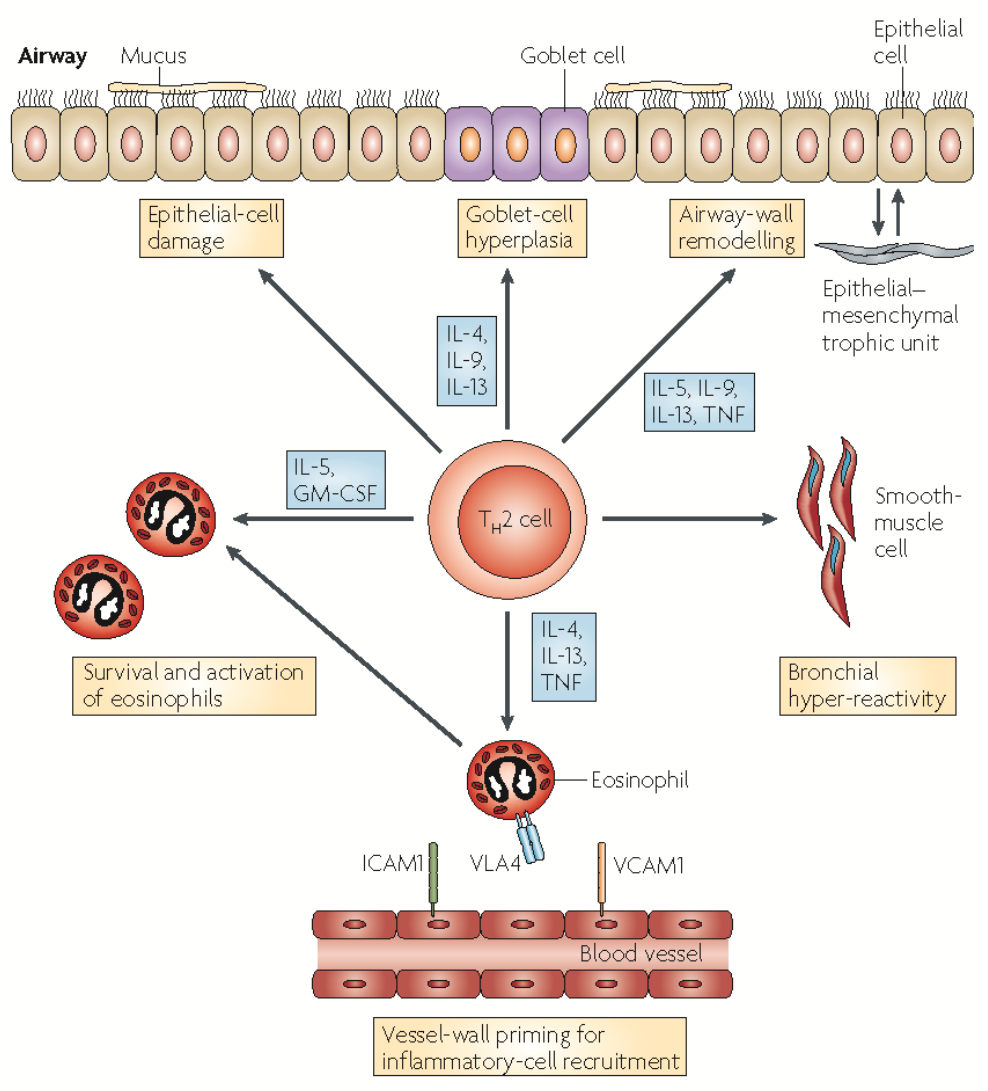

Figura 8. Esquema de la función de los linfocitos T. Coordinación de la respuesta inflamatoria en el asma mediante la liberación de citocinas tipo Th2 por los que se produce el reclutamiento de eosinófilos y el mantenimiento de mastocitos en las vías respiratorias [31]. 


\section{CÉLVLAS DENDRITICAS}

Las células dendríticas pulmonares son el nexo crucial entre la respuesta inmune innata y la respuesta inmune adaptativa en la patología asmática. Integran una variedad de estímulos provenientes de los alérgenos, la colonización microbiana, la contaminación ambiental, y las células inmunes innatas en una señal para los linfocitos T. Como células presentadoras de antígeno, desempeñan un papel fundamental en la activación de los linfocitos Th2 y la inflamación alérgica (figura 9). Las células dendríticas potencian la polarización de la repuesta hacia Th2 mediante una menor producción de IL-12, a raíz de la exposición a mediadores liberados por mastocitos, histamina y $\mathrm{PGD}_{2}$. Por otro lado, estas mismas células dendríticas también podrían prevenir la respuesta inmune frente a antígenos inocuos inhalados a través de la inducción de células Th1 [32].

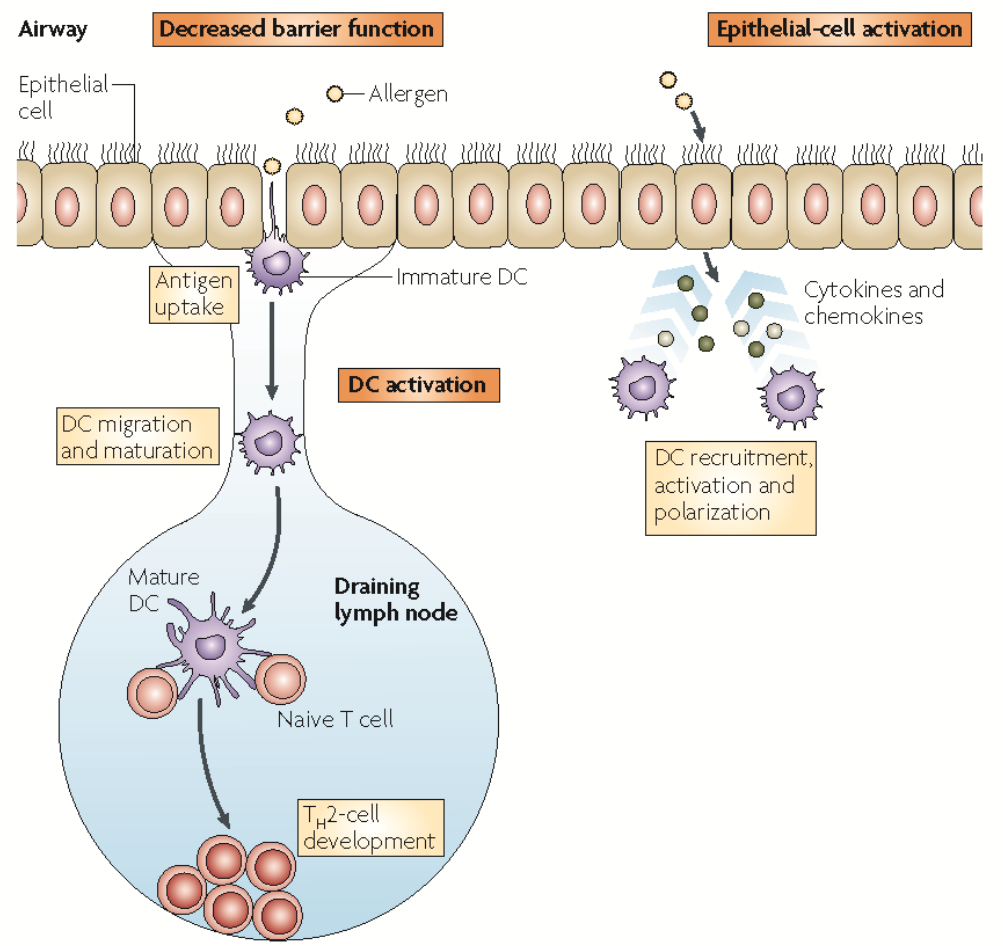

Figura 9. Papel de las células dendríticas pulmonares en el asma [31]. 


\section{CÉLVLAS EPITTELIIALES}

Aparte de la función de barrera físico-química frente a agentes nocivos, el epitelio participa en la inflamación de las vías respiratorias a través de varios mediadores. Entre las citocinas que produce se encuentran la IL-1 $\beta$, IL-6, IL-11, IL-13, IL-16, GM-CSF, TGF- $\beta$ y TSLP (linfopoyetina estromal tímica). Estas tres últimas son responsables de la activación de las células dendríticas de modo que colaboran con ellas en la inducción de la respuesta innata a la respuesta adaptativa (figura 10) [31].

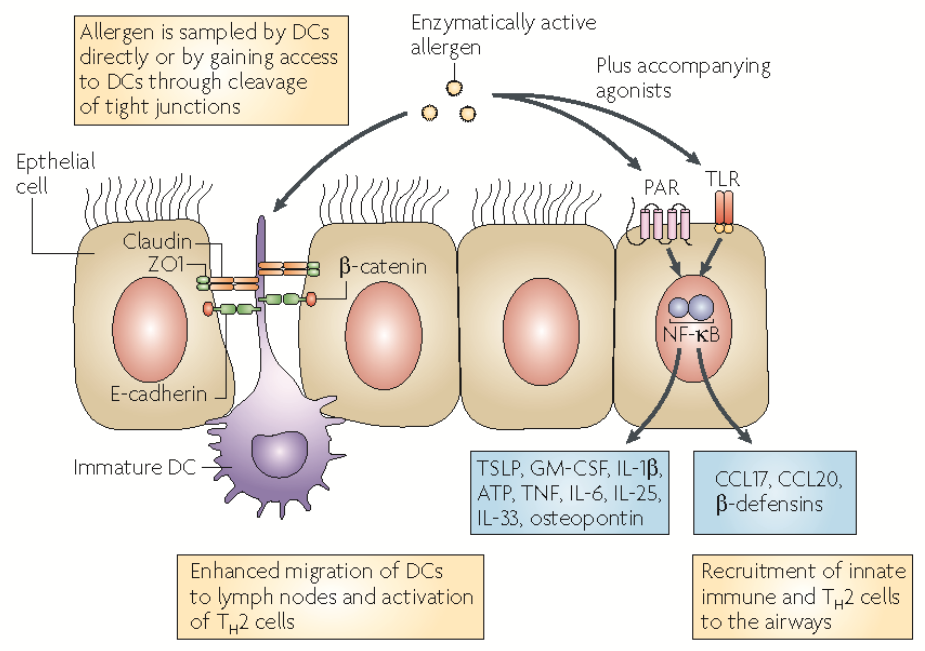

Figura 10. Células del epitelio pulmonar y su relación con las células dendríticas. Se detallan las citocinas secretadas por estas células, así como sus interacciones a nivel de membrana [31].

De las quimiocinas de secreción epitelial destacan la IL-8 y RANTES, y la eotaxina-1 (CCL-1) [33]. El óxido nítrico (NO), producido fundamentalmente por la óxido nítrico sintasa inducible (iNOS) de las células epiteliales de la mucosa [34], es un vasodilatador, pero también ejerce un efecto broncodilatador. También desempeña un papel importante en la neurotransmisión, la defensa 
inmunológica, la citotoxicidad, la frecuencia de batido de los cilios, y la secreción de moco. El NO exhalado se asocia con la presencia de inflamación en el asma, de manera que se puede utilizar para monitorizar el tratamiento [35].

\section{MACRO์FAGOS ALVEOLARES}

Predominan en la luz de las vías respiratorias, tanto en los sujetos normales como en la mayoría de los pacientes con asma. Secretan una amplia variedad de citocinas (GM-CSF, factor de necrosis tumoral (TNF) a, CXCL8, IL-10, IL-12), quimiocinas (eotaxina, CCL5); así como radicales de oxígeno $\left(\mathrm{NO}, \mathrm{H}_{2} \mathrm{O}_{2}, \mathrm{OH}^{-}\right.$, O2) y metabolitos del ácido araquidónico, protaglandinas y leucotrienos [36]. A través de estos mediadores probablemente los macrófagos desempeñen un papel en la patología asmática, amplificando la respuesta inflamatoria, reclutando linfocitos $\mathrm{T}$ mediante quimiocinas [37], disminuyendo la respuesta de los linfocitos T a través de IL-10 o reorientando la respuesta inmune hacia Th1 a través de IL-12 [38]. Son células que expresan el complejo principal de histocompatibilidad de clase II (MHC-II), por tanto también tienen la función de células presentadoras de antígeno a los linfocitos Th. Del mismo modo, pueden ser activados por los alérgenos a través de los receptores de baja afinidad para $\lg \mathrm{E}$ (Fc\&RII) presentes en su membrana celular [39].

\section{NEVTRO์FÍLOS}

La función de los neutrófilos en la patología asmática no está clara. Inicialmente se asociaron al asma grave puesto que se detectaba una acumulación de estas células en el esputo de estos pacientes [40] así como en sus vías respiratorias [41] o en biopsias de pacientes fallecidos a causa de esta enfermedad [42]. Incluso se planteaba si el incremento podía deberse al 
tratamiento con corticoides [41]. Sin embargo, estudios más recientes aportan pruebas de su papel en la etiopatogenia del asma bronquial. Se habla incluso de un subtipo de la enfermedad, distinto del caracterizado por infiltración eosinofílica, y que se conoce como asma neutrofílica. Los neutrófilos son reclutados y activados por la quimiocina IL-8 y su contribución en el proceso inflamatorio se debe a la liberación de enzimas como la elastasa, la mieloperoxidasa (MPO), la $\beta$-glucuronidasa; radicales libres y su propio activador IL-8 (figura 11) [43].

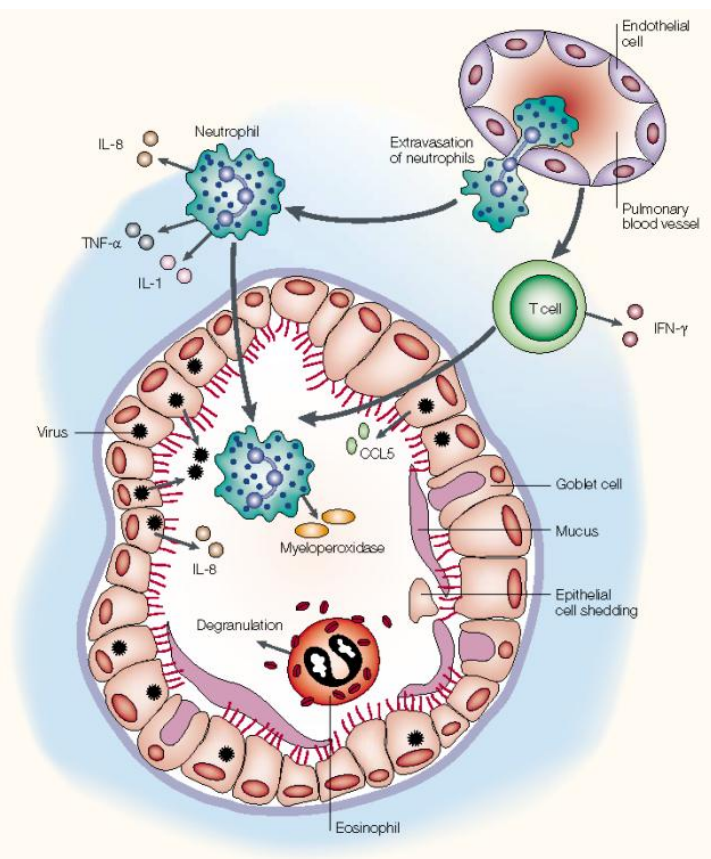

Figura 11. Papel de los neutrófilos en la respuesta inflamatoria en el asma [17].

\section{HİPERREACTIIVIDAD BRONQVIAAL (HRB)}

Consiste en un aumento de la sensibilidad de las vías respiratorias a estímulos broncoconstrictores. En los pacientes asmáticos se produce tanto ante estímulos químicos como físicos, como el ejercicio o el aire frío [44]. Los cambios estructurales en las vías respiratorias causan una disminución del calibre 
bronquial en estos pacientes, y podrían estar implicados en la patogénesis de la hiperreactividad. Se ha llegado a sugerir el daño epitelial como causa de la hiperreactividad de las vías respiratorias, principalmente a través de los mediadores liberados por dicho epitelio; sin embargo no se ha podido establecer la conexión funcional entre ambos [45]. Tal y como se describe a continuación, esta reestructuración tisular se traduce principalmente en un aumento del espesor de la membrana basal, hiperplasia y/o hipertrofia del músculo liso y daño epitelial, y se asocia con la liberación de citocinas y otros mediadores inflamatorios. A su vez la propia hiperreactividad bronquial conlleva estos cambios [46], de manera que la secuencia de acontecimientos que en el asma conducen a la presencia de células inflamatorias en las vías respiratorias, los cambios estructurales de las mismas, y la hiperreactividad está por determinarse.

\section{OBSTR VCCi@́N AL FLVJO AÉREO}

Uno de los signos que se identifican en el diagnóstico del asma es la obstrucción al flujo aéreo generalmente reversible; sólo en algunos casos se mantiene un componente de obstrucción irreversible como en los individuos con asma persistente. Esta obstrucción es consecuencia de la combinación de los mecanismos inflamatorios de las vías respiratorias característicos del asma.

\section{REESTR VCTVRACiÓN DE LA VÍAS RESPIRATORİAS}

Como consecuencia de la respuesta inmune, en las vías respiratorias de los pacientes asmáticos pueden producirse cambios estructurales que afectan al tejido a distintos niveles. Se traducen en un engrosamiento de la pared bronquial, fibrosis y aumento de la secreción mucosa; efectos que se asocian a 
la obstrucción de las vías respiratorias y a la pérdida de la función pulmonar (figura 12).

El proceso es complejo y en él se involucran citocinas, factores de crecimiento y moléculas de adhesión, que interaccionan con células epiteliales y musculares a nivel de la producción de la secreción mucosa y de la vascularización de la vía respiratoria. Entre los componentes afectados destacan el epitelio, subepitelio, glándulas mucosas, músculo liso y vasos sanguíneos.

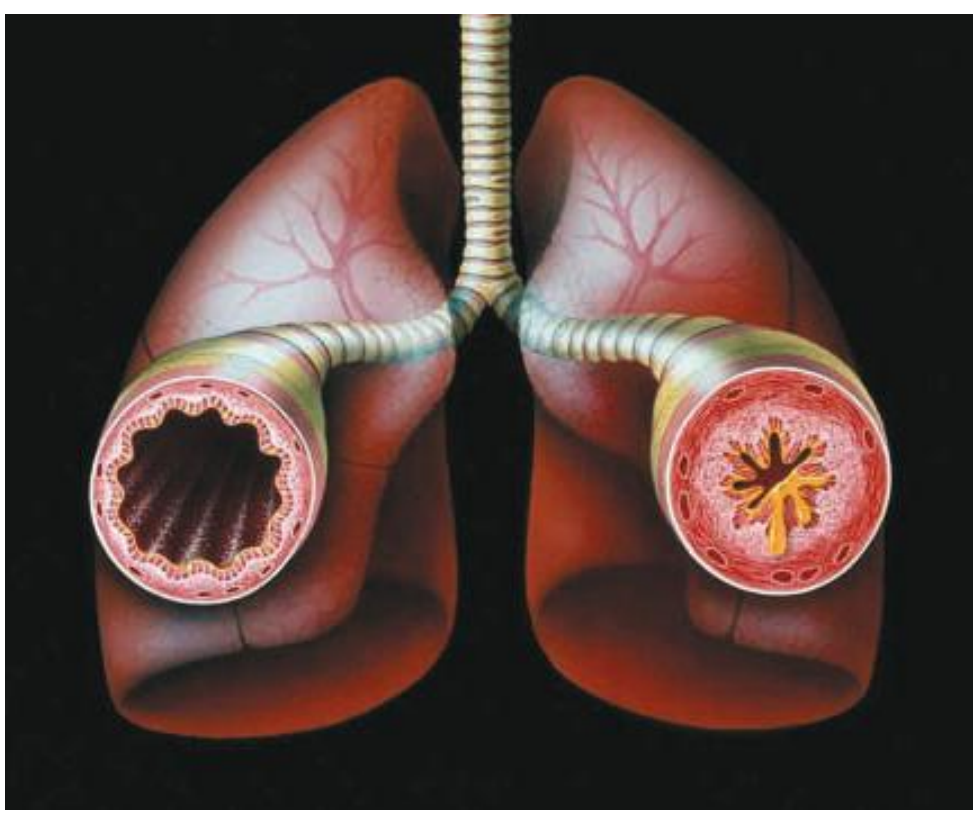

Figura 12. Representación de la reestructuración de las vías respiratorias en asma. Comparación de una vía respiratoria normal (izquierda) y una vía respiratoria limitada (derecha) como consecuencia de la reestructuración del tejido a distintos niveles [47].

EPíTELí: La integridad del epitelio respiratorio se puede perder en los individuos asmáticos. Se detecta una descamación del epitelio debida a la apoptosis de las células epiteliales [48], aunque el significado funcional de estos cambios no se conoce bien (figura 13). El grado de destrucción del 
epitelio va a depender fundamentalmente de la gravedad del asma [49] y se considera un rasgo característico del asma crónica.

SVBEPITELiO: Se produce una fibrosis subepitelial por una acumulación anormal de colágeno de los tipos I, III y V, proteoglicanos y otros elementos de la matriz extracelular (figura 13). Como consecuencia del aumento de la síntesis de estos compuestos y una menor degradación de la propia matriz, se forman depósitos de tejido conectivo que se distribuyen por la membrana basal de forma homogénea y aumentan así su espesor [47]. Sin embargo, no se cuenta con datos concluyentes del grado de ensanchamiento como indicador de la gravedad del asma [50].
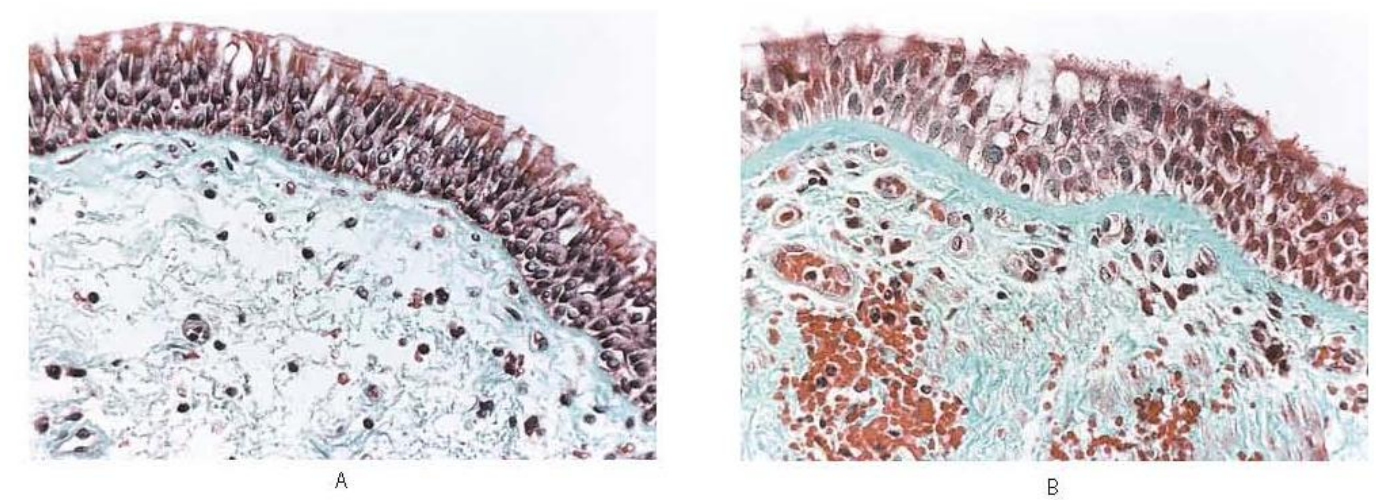

Figura 13. Afectación a nivel del epitelio bronquial en asma. Preparaciones de mucosa bronquial de un sujeto sin asma (A) y un sujeto con asma leve (B). Se compara el epitelio bronquial intacto del primer individuo con el segundo caracterizado por un engrosamiento de la membrana basal, infiltración celular e hiperplasia de las células caliciformes [16].

GLÁNDVLAS MVCOSAS: La hiperplasia de las células caliciformes y la hipertrofia de las glándulas mucosas provocan un aumento en la secreción mucinosa hacia el lumen (figura 13). Esta secreción se caracteriza por una mayor viscosidad, debido a la presencia del exudado inflamatorio compuesto 
por las células inflamatorias y sus productos [47]. Los estudios epidemiológicos sitúan a la hipersecreción de moco como marcador de la gravedad del asma [51].

MV́SCVLO LíSO: La contracción del músculo liso bronquial provoca un estrechamiento las vías respiratorias y, además, contribuye a la inflamación bronquial mediante la secreción de una serie de mediadores inflamatorios, citocinas y moléculas de adhesión [52], así como el reclutamiento y activación de células inflamatorias como mastocitos o linfocitos T [53]. Tanto la hiperplasia como la hipertrofia de las células del músculo liso producen un aumento del componente muscular de la pared de las vías respiratorias en el asma [54], este aumento también se ha relacionado con un depósito de proteínas de la matriz extracelular; sin embargo, los mecanismos de esta remodelación del músculo liso son complejos [53].

VASOS SANGVíNEOS: El aumento de la vascularización de la pared de las vías respiratorias en el asma se asocia a una mayor expresión de factores angiogénicos como el factor de crecimiento vascular endotelial (VEGF) [55, 56]. Estos cambios en la microcirculación podrían favorecer la aparición de edema en la vía respiratoria.

\subsection{ETi̊lOGía}

Hoy en día se desconocen las causas concretas responsables de la aparición del asma. Los factores genéticos y ambientales interactúan de manera compleja para producir tanto la susceptibilidad a la enfermedad como su expresión. La variedad de fenotipos de esta patología se explicaría por la 
interacción entre la predisposición genética del individuo y los factores ambientales a los que se ve expuesto.

En la patología asmática, se puede hablar de factores de riesgo, relacionados con la aparición del asma y de factores que desencadenan sus síntomas.

\section{FACTORES DE RIIESGO}

\section{FACTORES GENETICOS}

A lo largo del tiempo, un número considerable de genes y regiones cromosómicas se han asociado al asma y la atopia; aunque no siempre se cumplen estas asociaciones en función del grupo étnico que se estudie. La complejidad del componente hereditario de esta enfermedad será abordada más adelante.

\section{FACTORES MATERNOS}

Durante el embarazo, el útero materno proporciona un entorno inmunológicamente seguro para el feto, donde se le protege del rechazo mediante la acción de citocinas Th2 (IL-4 e IL-13) y de células T reguladoras (IL10 y TGF $\beta$ ) que inhiben la respuesta materna de tipo Th1, a la vez que participan en el desarrollo fetal (figura 14).

Se piensa que una alteración del equilibrio en la producción de citocinas de la madre, de la placenta y del feto tendría un impacto en el riesgo posterior de desarrollar una enfermedad alérgica [57]. Un predominio demasiado acentuado de las citocinas inhibidoras de la respuesta Th1 podría determinar la aparición 
posterior de asma, alergia o ambas en el individuo. Además, se plantea que la existencia de alergia materna implicaría una mayor desviación hacia la respuesta Th2 fetal, y por tanto explicaría que el riego de desarrollar una enfermedad alérgica en la infancia esté más relacionado con la presencia de alergia materna que paterna. Por otro lado, aunque la lgE no atraviesa la placenta, se ha observado que en las madres atópicas los niveles de $\lg E$ en líquido amniótico son proporcionales a los de la circulación materna [58]. De aquí la hipótesis de que la interacción en el líquido amniótico entre la $\lg \mathrm{E}$ y sus receptores en células presentadoras de antígeno del intestino fetal produciría una sensibilización alérgica en el feto a concentraciones de antígeno extremadamente bajas [59].

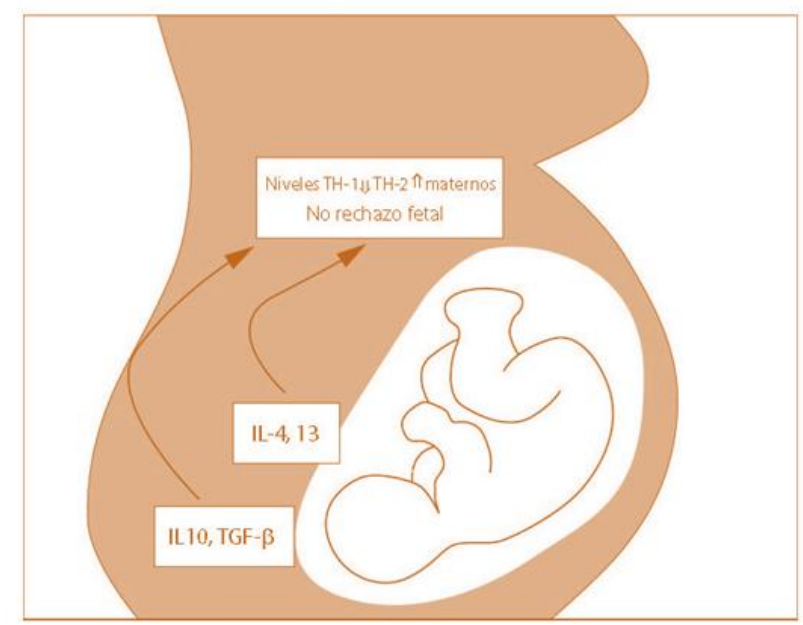

Figura 14. Citocinas en el espacio intrauterino durante el embarazo. Esquema de las interacciones materno-feto-placentarias [57].

Por otro lado, deben evitarse determinadas prácticas durante el embarazo que pongan en peligro el desarrollo pulmonar del feto. El tabaquismo, la desnutrición de la madre o la ingestión de comida rápida, las infecciones e incluso el estrés durante el embarazo se consideran factores de riesgo para la aparición de alteraciones en la función pulmonar fetal, de manera que deben ser prevenidos en la medida de lo posible [60]. 


\section{INFECCIONES}

Numerosos estudios han sugerido que existe una relación inversa entre la exposición temprana a productos microbianos y el riesgo de desarrollar alergia o enfermedades alérgicas. Esta exposición aceleraría la disminución de la respuesta Th2 aumentada con la que nacen todos los niños. Se ha demostrado una menor prevalencia de atopia respecto a la respuesta a la tuberculina, la hepatitis A y el sarampión en la primera infancia [57].

Estos hallazgos entre otros, sustentan la "hipótesis higienista", según la cual los hábitos higiénicos de las sociedades occidentalizadas han provocado un aumento en la prevalencia del asma en estas regiones; ya que el sistema inmune de estos individuos no interacciona con productos microbianos, ni se produce una colonización temprana del tracto intestinal y se da un uso frecuente de antibióticos; de manera que, la disminución de la respuesta Th2 en el individuo se retrasa (figura 15) [61]. La dificultad estriba en establecer si las infecciones asociadas a un menor riesgo de alergia regulan verdaderamente a la baja la respuesta Th2 o son un indicador de algún otro componente de la higiene; ya que en algunos estudios en países más desarrollados no se ha encontrado este posible efecto "protector" de la infección por sarampión frente a la atopia [62]. Igualmente, existe controversia en cuanto al uso frecuente de antibióticos en la infancia, que tanto se vincula a un mayor riesgo de padecer asma como no se detecta ninguna asociación entre ambos [63].

Esta misma hipótesis también se basa en estudios en los que se ha detectado una menor prevalencia de atopia entre los hijos de agricultores o niños que en su más temprana infancia han convivido con un gato o un perro en sus hogares, lo cual se traduce en una mayor exposición a la endotoxina o lipopolisacárido bacteriano [64]. En la misma línea se plantea que la colonización 
microbiana del tracto intestinal tendría un efecto modulador sobre el sistema inmune [65].

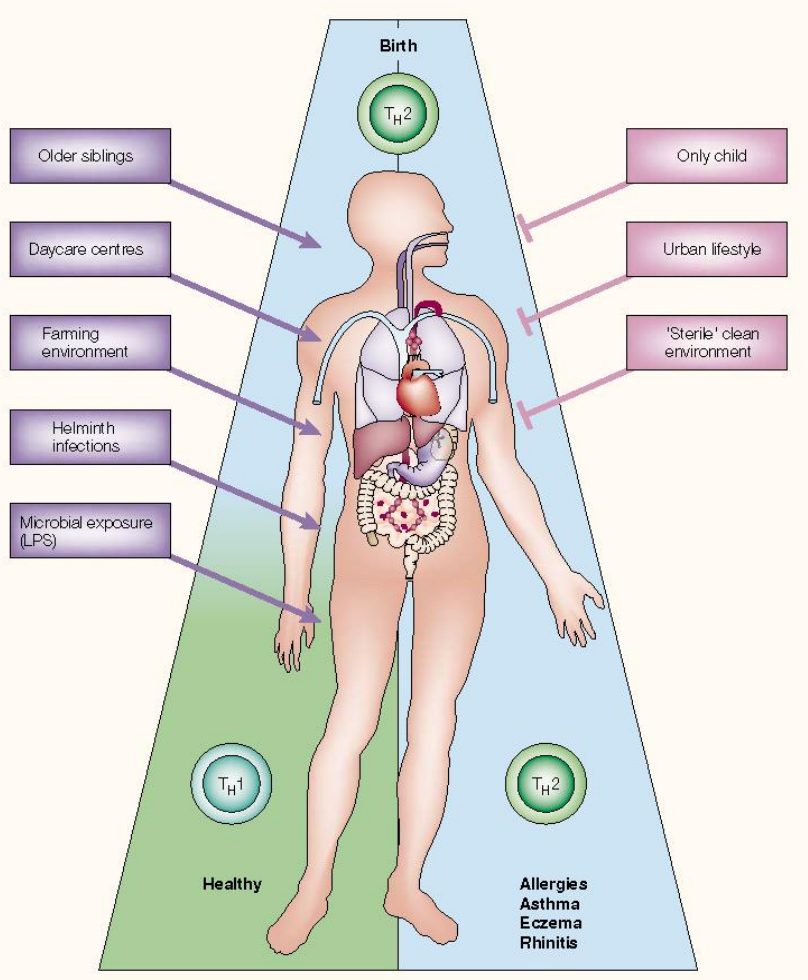

Figura 15. Hipótesis higienista [17].

En contraposición con la "hipótesis higienista" está el hecho de que las infecciones del tracto respiratorio causadas por virus han sido relacionadas con la patogénesis del asma (figura 16). Entre ellos, los Rinovirus y el Virus Respiratorio Sincitial (VRS) han demostrado una participación en la expresión inicial del asma en la primera década de la vida [66, 67], así como en la descompensación de los pacientes que ya padecían la enfermedad [68]. Las infecciones microbianas del tracto respiratorio que también pueden causar exacerbaciones en los pacientes y persistencia y/o mayor gravedad del asma crónica son las causadas por Mycoplasma [69] y Chlamydia [70]. 


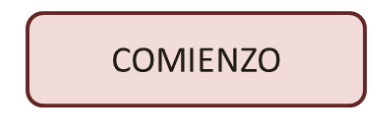

Niño sano

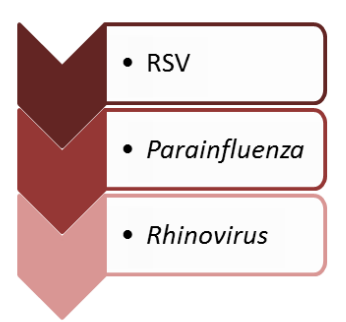

Trastornos respiratorios (sibilancias)

\section{EXACERBACIÓN}

Niño o adulto asmático

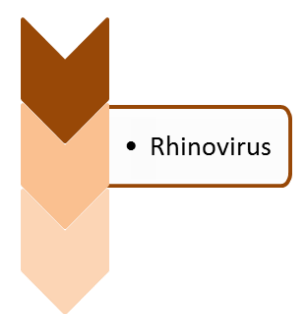

Exacerbación del asma

\section{PERSISTENCIA}

Adulto (? Pre-afectado de asma)

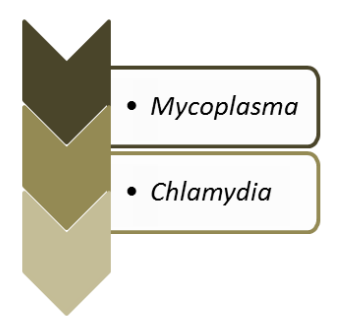

Asma persistente

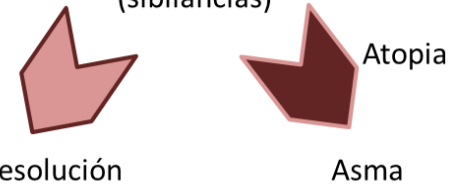

Figura 16. Infecciones del tracto respiratorio y asma. Las infecciones en el tracto respiratorio pueden desempeñar un papel importante en el comienzo, y desarrollo del asma; así como en su persistencia y gravedad.

\section{OBESIDAD}

En la bibliografía médica, el asma se ha asociado con la obesidad. Ambas entidades presentan influencias genéticas e, incluso, podrían estar compartiendo parte de ese componente genético [71]. Así, determinadas moléculas mediadoras del estado inflamatorio asociado a la obesidad son objeto de estudio desde hace tiempo (figura 17). Entre ellas destaca la leptina, cuya capacidad para regular la proliferación de linfocitos $T$ y reclutar y activar células como monocitos y macrófagos ya ha sido demostrada; algo que, por otro lado, era una cuestión esperable dada su homología estructural con citocinas como la IL-6 [72]. En el caso de los niños, algún estudio reciente ha encontrado asociación entre el asma y alteraciones en el metabolismo de lípidos e hidratos de carbono [73]. 


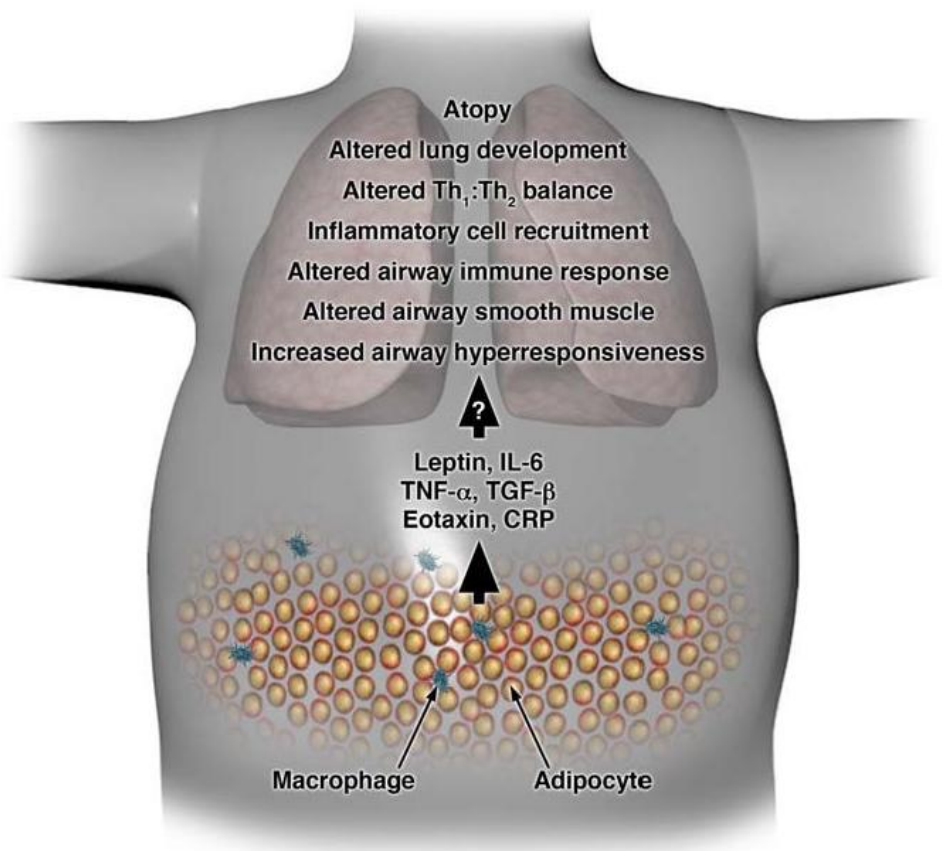

Figura 17. Hipótesis de la relación entre obesidad y asma. Citocinas proinflamatorias generadas por el tejido adiposo en el individuo obeso [72].

\section{FACTORES DESENCADENANTES}

\section{AEROALÉRGENOS}

Muchos estudios epidemiológicos han determinado la exposición a aeroalérgenos como un desencadenante importante del asma [74]. Los estudios realizados con inhalación de alérgenos han determinado su papel en el desarrollo del proceso inflamatorio. Pocas horas después de su presencia en las vías respiratorias se produce el reclutamiento de eosinófilos y basófilos, la liberación de sus mediadores pro-inflamatorios en el epitelio bronquial [75] y la estimulación a nivel de médula ósea [76].

Más del $80 \%$ de los niños con asma presentan sensibilidad a estos aeroalérgenos en las pruebas cutáneas, especialmente frente a los alérgenos 
que se encuentran en el entorno más inmediato, como es el domicilio [74, 77]. Entre ellos destacan los ácaros domésticos, la cucaracha, los hongos ascomicetos del género Alternaria y los epitelios de animales; que a su vez son los más relacionados con el asma, siempre en función de cada situación particular de grado de exposición.

\section{EJERCICIOO FÍSiCO}

Un ejercicio de intensidad suficiente puede desencadenar exacerbaciones agudas en prácticamente todas las personas con asma [78]. La broncoconstricción inducida por el ejercicio físico es común en asmáticos [79] y se puede observar incluso en individuos no diagnosticados de esta patología [80, 81]. Dicha broncoconstricción se produce a raíz de los esfuerzos de las vías respiratorias durante el ejercicio por elevar la temperatura y disminuir la osmolaridad tras la pérdida de agua respiratoria. Esta situación tiene una base inflamatoria, el aumento de la osmolaridad en las vías respiratorias induce a las células inflamatorias, mastocitos y eosinófilos a la liberación de mediadores broncoconstrictores como histamina, prostaglandinas y leucotrienos cisteinílicos (figura 18) [80].

Las posibles opciones de tratamiento para el asma inducida por el ejercicio son tanto farmacológicas como no farmacológicas. Los agonistas de los receptores adrenérgicos $\beta 2$, agentes estabilizantes de mastocitos, anticolinérgicos, antagonistas de los receptores de leucotrienos, y los corticosteroides inhalados constituyen opciones terapéuticas adecuadas. La preparación física, un calentamiento previo al ejercicio y un período de enfriamiento posterior o la realización de la respiración nasal son algunas de las recomendaciones no farmacológicas en estos casos [82]. 


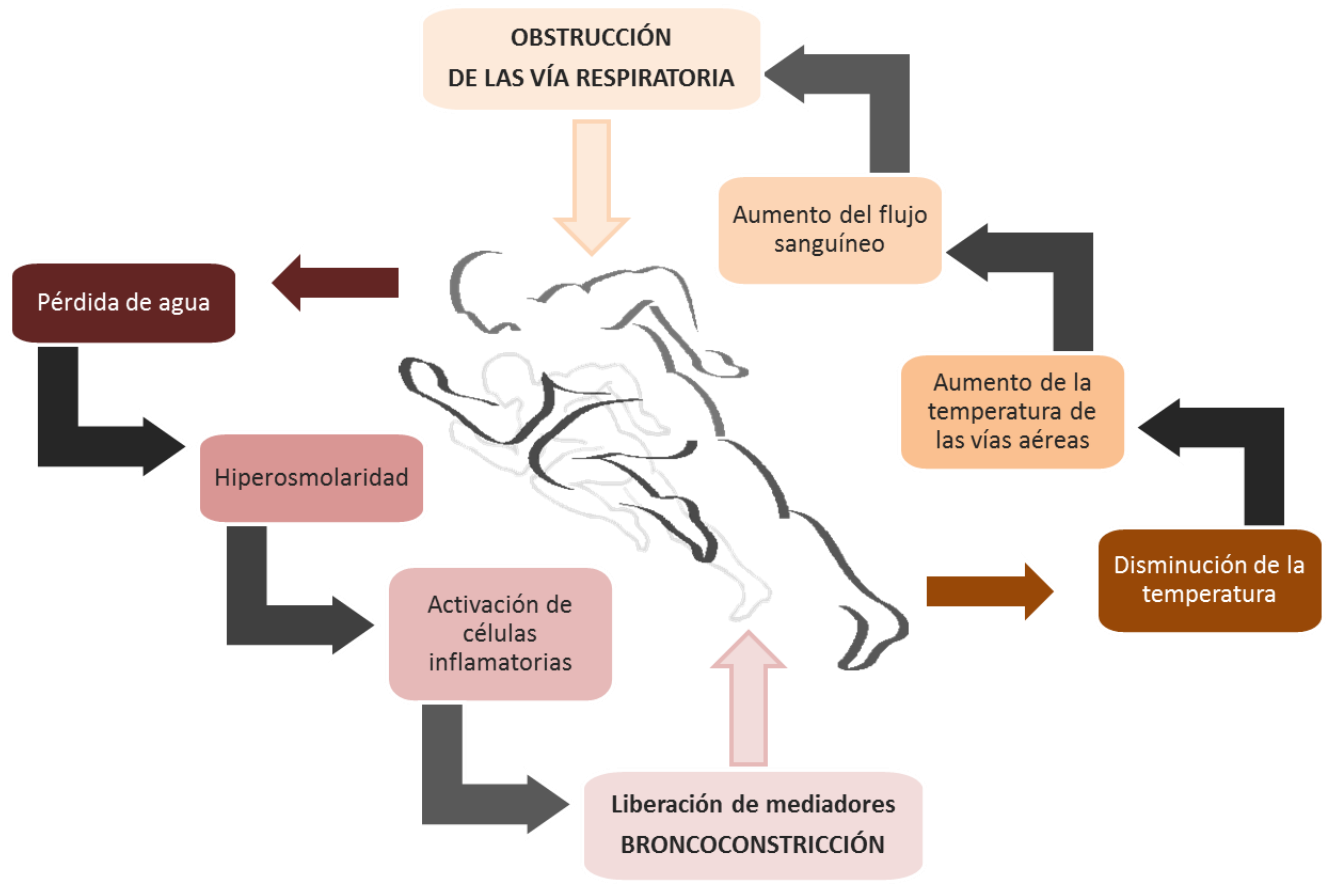

Figura 18. Secuencia de efectos del ejercicio físico en las vías respiratorias.

\section{TABACO}

La información científica disponible sobre los efectos y consecuencias del tabaquismo en la patología asmática es limitada [83]. Sin embargo, desde hace un tiempo se conoce que los asmáticos fumadores tienen más síntomas, más morbilidad y peor calidad de vida relacionada con la salud que los asmáticos no fumadores [84]. A raíz de otros trabajos, la exposición al tabaco se asociaría con el desarrollo y la gravedad del asma bronquial, valorada por la asistencia a los servicios de urgencias hospitalarios [84, 85]. El humo del tabaco, como agente irritante que es, podría potenciar el componente inflamatorio de patologías como el asma o la enfermedad pulmonar obstructiva crónica (EPOC), activando a las células epiteliales y a los macrófagos alveolares para la liberación de numerosos mediadores, como factores de crecimiento que estimulan la proliferación de fibroblastos; citocinas proinflamatorias como TNF- $\alpha$, IL-1 $\beta$, e IL-6, y quimiocinas 
que recluten células inflamatorias circulantes [86]. Por otro lado, el consumo de tabaco podría interferir en el tratamiento del asma reduciendo la efectividad de los corticosteroides (figura 19) [87].

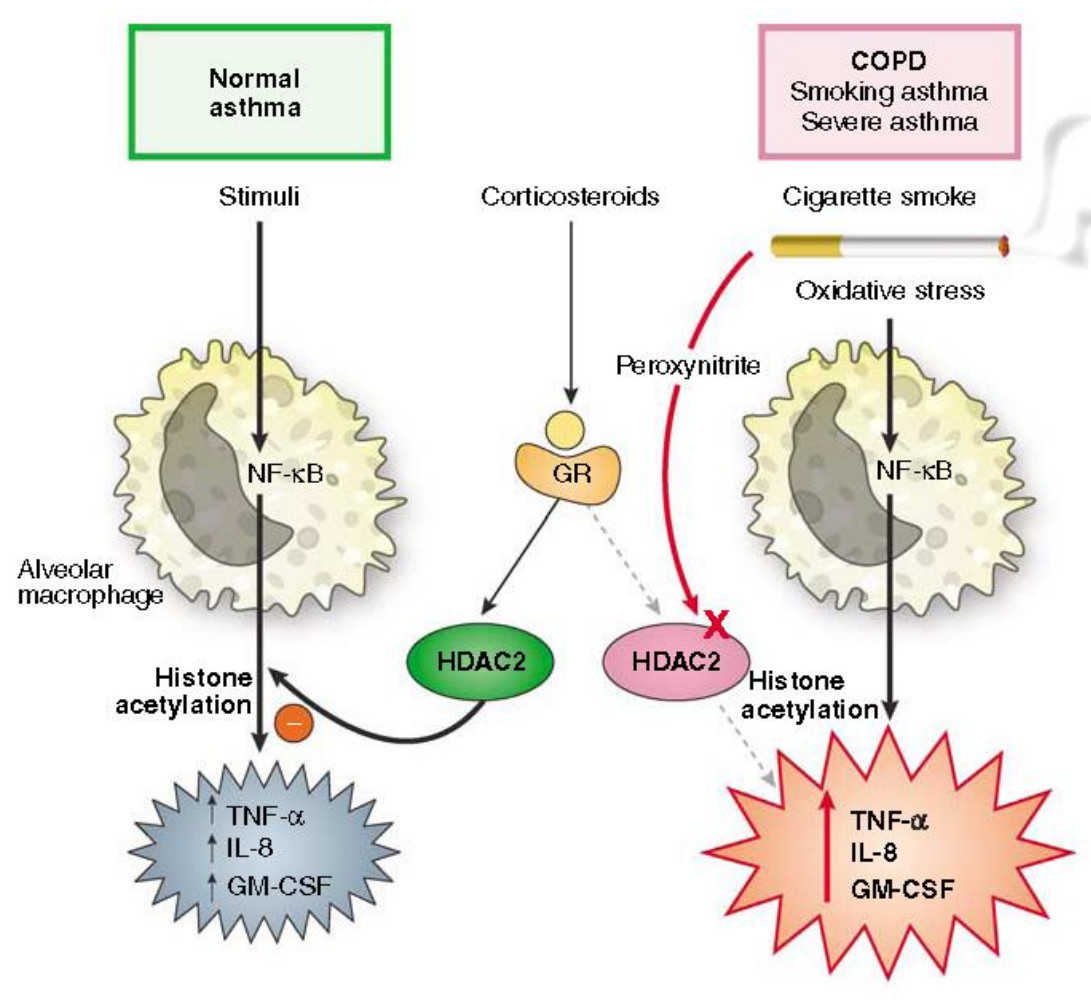

Figura 19. Posible mecanismo de interferencia del tabaco en la acción de los corticosteroides. COPD (Chronic Obstructive Pulmonary Disease) $=$ EPOC [76].

\section{CONTAMINANTES AMBIENTALES}

Los estudios epidemiológicos han evidenciado que la contaminación atmosférica empeora la función pulmonar del paciente asmático, lo cual se ha confirmado con datos analíticos. Los contaminantes ambientales contribuyen a la inflamación de las vías respiratorias e incluso aumentan la sensibilidad a los alérgenos inhalados, facilitando el acceso de los mismos a las vías respiratorias, cuya mucosa se mantiene dañada a causa de la propia contaminación. 
En concreto, en las zonas urbanas, caracterizadas por niveles elevados de tráfico rodado, los contaminantes más abundantes son el dióxido de nitrógeno, las partículas derivadas de la combusión de los motores diesel y el ozono. Por otro lado, a causa de la actividad humana en cuanto a la combustión de carburantes y emisión de gases con efecto invernadero se está produciendo un aumento de temperatura de la tierra. Dicho calentamiento global altera la distribución de las partículas contaminantes y puede alargar los períodos de exposición a los pólenes más allá de la fase estacional. [88].

\section{DIETA}

El modo de vida occidental se ha caracterizado por una disminución del consumo de frutas y hortalizas frescas que ha coincidido con un incremento de enfermedades atópicas. Estos alimentos contienen antioxidantes que podrían estar implicados en la protección de las vías respiratorias frente a la inflamación. Sin embargo, puede haber un efecto aún más importante sobre el equilibrio Th-1/Th-2 por parte del ácido retinoico y sus distintas formas de las cuales se demostró su capacidad para inhibir la producción de IgE dependiente de IL-4 en células $B$ de ratón [89].

\section{GENETICA Y ASMA}

Los estudios de segregación familiar y de gemelos que se sucedieron desde la década de los 80 no hicieron sino confirmar la importante contribución del componente genético en el asma [90-94], evidenciada desde principios del siglo XX [95]. A partir de los estudios con gemelos, se comprobó que la concordancia en el fenotipo de la enfermedad era mayor entre gemelos monozigóticos que dizigóticos y se estimó la heredabilidad de esta patología en un 36-79\% [96]. Del 
mismo modo se pudo determinar que el asma no sigue un patrón de herencia mendeliano sino que, como se fue observando a lo largo del tiempo, es un síndrome multifactorial consecuencia de la interacción compleja entre diversos factores genéticos y ambientales [97].

Sin embargo, conceptos del asma como enfermedad poligénica o de herencia dominante se cruzaron en los años 80. En 1986 se demostró una distribución unimodal en la respuesta de las vías respiratorias a la metacolina en sujetos no asmáticos y confirmó una distribución bimodal de la reactividad bronquial al agonista colinérgico en familias con y sin asma [98].

Fue a partir de la década de los 90 cuando se comenzó a entender el asma como una enfermedad compleja, considerando la influencia de diversos genes que determinarían su aparición. Los estudios en genética molecular como el publicado por Palmer y colaboradores han ido identificando numerosos genes asociados con los rasgos fisiopatológicos del asma y con el desarrollo de la enfermedad [99].

\section{ESTVDIOS GENETICOS}

La búsqueda de los genes asociados con el asma se ha llevado a cabo mediante dos estrategias fundamentalmente: estudios de ligamiento o de familias a lo largo de todo el genoma; y estudios de desequilibrio de ligamiento o de asociación con genes candidatos; y también, recientemente, estudios de asociación en el genoma completo (GWA: Genome Wide Association analysis). Sobre esta base se han determinado diferentes regiones cromosómicas en las cuales se encontrarían localizados genes implicados en la patología asmática; así como la existencia de variantes génicas asociadas estadísticamente con esta enfermedad que también podrían participar en su patogenia. 


\section{ESTVDIOS DE LIGAMİENTO}

Los estudios de ligamiento se llevan a cabo en familias. Se basan en que los individuos emparentados más parecidos fenotípicamente, como serían aquellos familiares que padecen una determinada enfermedad, deberían haber recibido con una probabilidad mayor los mismos alelos de sus progenitores, en cuanto a los loci implicados en dicha patología, que aquellos individuos pertenecientes a la misma familia pero con mayores diferencias en el fenotipo, es decir, que no presentan la enfermedad (figura 20). Se analizan numerosos marcadores genéticos distribuidos a lo largo de todo el genoma, tales como los microsatélites, y se analiza si alguno de ellos es más frecuente en individuos afectos. En estos mismos individuos se pueden analizar los QTL (Quantitative trait loci= loci de rasgos cuantitativos). Las diferencias encontradas se deberán a la presencia de un locus implicado, lo suficientemente próximo al marcador que pone de manifiesto esta situación.

El estudio de ligamiento es más consistente que el de asociación, pero la localización del gen implicado en la enfermedad se determina con una imprecisión mayor [15]. La ventaja de este tipo de estudios es que permiten identificar nuevos genes y rutas implicadas en enfermedades complejas [100].

Los estudios de ligamiento a lo largo de todo el genoma que se han llevado a cabo en el asma y en otras enfermedades alérgicas han determinado unas 20 regiones cromosómicas ligadas a esta patología o a patologías relacionadas [101-104]. Los resultados con diferentes fenotipos de la enfermedad y distintos niveles de significación estadística tienen un componente étnico, aunque la mayoría de estas regiones se han replicado en más de un estudio. Las más importantes son 2q33, 5q23-31, 6p24-21, 11q21-13, 12q24-12 y 13q14-12; ya que contienen un gran número de genes candidatos [105]. Hasta hace poco, el 
análisis de estas grandes regiones ha sido difícil, debido a la falta de disponibilidad de mapas de alta resolución de desequilibrio de ligamiento (figura 20). La situación comenzó a cambiar con la identificación de la metaloproteasa ADAM33 (Disintegrin and metalloproteinase domain-containing protein 33) en el brazo corto del cromosoma 20 [15].

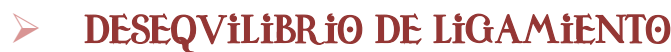

Es importante remarcar en este punto la diferencia entre ligamiento genético y desequilibrio de ligamiento. Este último se define como la probabilidad aumentada de que dos loci se hereden juntos respecto de lo que se esperaría en una situación de independencia.

En principio, el desequilibrio de ligamiento va disminuyendo a medida que aumenta la distancia génica, aunque no de una manera uniforme (figura 20). Esto se debe a que depende de las frecuencias alélicas y estas, a su vez, dependen de los fenómenos de selección, recombinación o migración a los que están sujetos las poblaciones. 
A

B
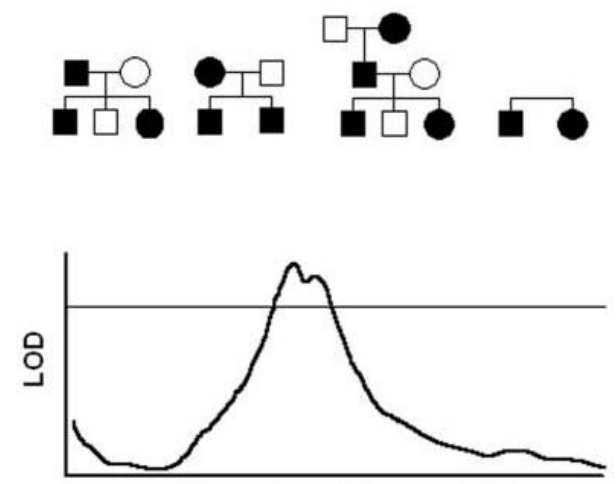

Chromosome distance (cM)

C

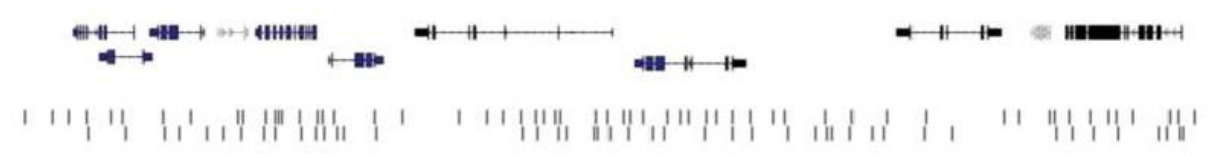

D

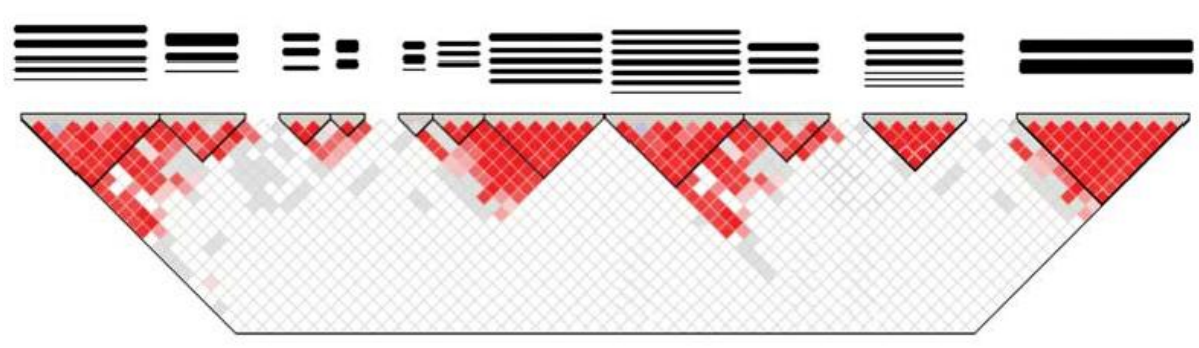

E

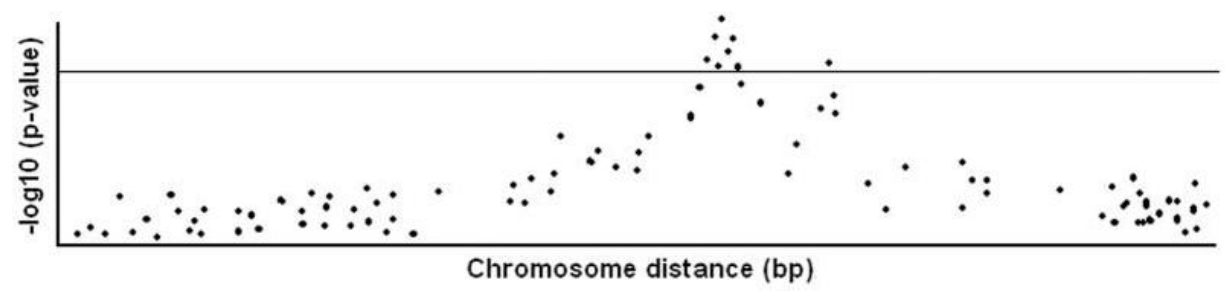

Figura 20. Estrategias en búsqueda de genes asociados con enfermedades complejas como el asma. (A) Árboles genealógicos del análisis de ligamiento. (B) Análisis de ligamiento del genoma completo con marcadores. Identificación de regiones genómicas asociadas por encima de la línea fina. (C) Mapa de la región identificada mediante ligamiento, incluyendo la localización de genes (líneas horizontales) y el mapa de densidad de la variabilidad genética (Variantes representadas por barras verticales por debajo de los genes). (D) Representación gráfica del patrón de desequilibrio de ligamiento (LD) en una región. Los triángulos indican las regiones de alto LD correspondiente a los bloques de haplotipos. (E) Mapa de alta resolución de desequilibrio de ligamiento dentro de las regiones determinadas en los estudios de ligamiento [15]. 


\section{ESTVDIOS DE ASOCIACiÓN}

Se consideran estudios poblacionales en los que se genotipan loci candidatos a intervenir en la enfermedad y se comparan las frecuencias alélicas y genotípicas entre afectos y sanos en una población de individuos no emparentados. El razonamiento de estos análisis se basa en que comparando todos los haplotipos de todos los portadores de la enfermedad se determinaría la región compartida por todos ellos donde se encuentra el gen implicado en dicha patología. Siendo el haplotipo la combinación de los genes o marcadores genéticos contenidos en uno de los cromosomas del par cromosómico que tienden a heredarse juntos; mientras que un diplotipo es la pareja de haplotipos de un individuo determinado (figura 21).

Es un análisis más preciso que el de ligamiento, con mayor capacidad para detectar polimorfismos que confieran un riesgo moderado de enfermedad [106]. Sin embargo, resulta difícil controlar el número de falsos positivos y depende mucho de un buen muestreo para no confundir los resultados de asociación con la enfermedad, con la estratificación de la población.

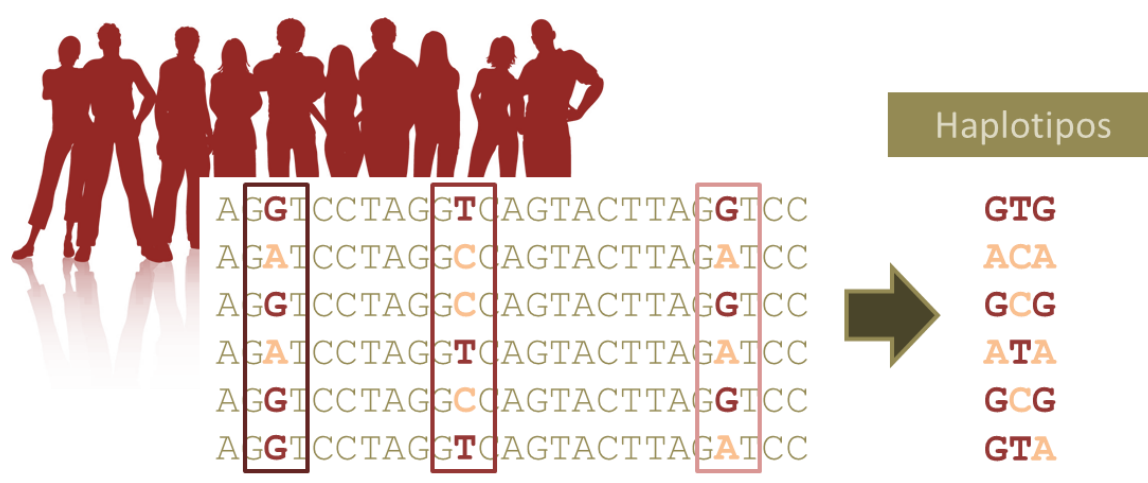

SNPS G>A T $>$ C $\quad$ G $>$ A

Figura 21. Representación gráfica de los polimorfismos y haplotipos. 
Los polimorfismos $(\mathrm{SNP}=$ Single Nucleotide Polymorphism) o variaciones en la secuencia de ADN de un determinado gen que afectan a un núcleotido y están presentes en $>1 \%$ de la población (figura 21). Pueden encontrarse en regiones codificadoras, con lo cual podrían alterar la estructura de la proteína que sintetizan, o bien, en regiones promotoras, en cuyo caso estarían implicando cambios en la expresión de las proteínas a través de los sitios de unión a los factores de transcripción u otros mecanismos, o bien en regiones intrónicas con la posibilidad de modificar el patrón de procesamiento de los mensajeros en determinados tejidos. Por último, se incluye la posibilidad de que estos pequeños cambios sean silentes y no impliquen un cambio de aminoácido en la secuencia [4]. La confirmación de los efectos funcionales de estas variaciones se ha realizado en diferentes variantes de los genes candidatos asociados con el asma, descartando que dicha asociación se deba a que estos se encuentren en desequilibrio de ligamiento con otros SNP realmente implicados en la enfermedad $[4,107]$.

\section{$>$ ESTVDIOS DE GENOMA COMPLETO (GWA: GENOME WIDE} ASSOC亡ATION ANALYSIS)

Los avances tecnológicos en la secuenciación masiva y en el empleo de micromatrices (microchips) han determinado nuevas estrategias en los estudios de asociación de polimorfismos con la susceptibilidad de padecer una determinada enfermedad compleja o alguno de sus síntomas. En este tipo de análisis de asociación se considera fundamental la caracterización y muestreo de los individuos participantes, especialmente en el caso de los controles [108]. Otra de las consideraciones a tener en cuenta es la necesidad de un tamaño muestral grande con el fin de conseguir un poder estadístico aceptable que permita identificar los alelos de interés. Sin olvidar que la enorme cantidad de datos generados hace imprescindibles conocimientos y herramientas 
bioinformáticas estadísticas avanzadas para su procesamiento que permitan distinguir resultados verdaderamente positivos, y eviten los falsos positivos. El hecho de trabajar con muestras tan grandes puede afectar a la buena caracterización de los individuos y, del mismo modo, aportar una considerable heterogenicidad del componente ambiental, especialmente relevante en el desarrollo de enfermedades complejas como el asma [109]. Las expectativas en torno a estos estudios no se han cumplido en cuanto a su relevancia, ya que, en general, no han aportado nuevas asociaciones de las que ya se conocían, excepto algunos concretos [110]. Por otro lado, la posibilidad de replicar los resultados obtenidos es bastante limitada, por lo que las conclusiones extraídas deben ser analizadas con cierta prudencia [111].

\section{GENES ASOCIADOS AL ASMA}

Dada la heterogeneidad y complejidad de la patogénesis del asma, no es de extrañar que hayan sido muchos los genes asociados a esta enfermedad. Las diferencias metodológicas, en cuanto a niveles de significación, poder estadístico, definición de los fenotipos, criterios de selección o tamaño de la muestra entre los distintos estudios, se han traducido en una limitación en la transferibilidad y, en muchos casos, la replicación de los datos constituye un problema [112].

Los estudios genéticos iniciales confirmaron la asociación con la región MHCII (Mayor Histocompatibility Complex Clase II, Complejo Principal de Histocompatibilidad de Clase II) [113], la agrupación del gen de la IL-4 [114] y el receptor de alta afinidad para $\lg E$ [115]. Investigaciones posteriores aportaron nuevas asociaciones de genes en los cromosomas 5, 7, 11, 12, 13, 14 y 19 [112]. A partir de estudios clonación posicional de algunas regiones descubiertas 
en los análisis de ligamiento, se incrementó esta lista de genes asociados al asma en determinadas poblaciones, con ADAM33, CYFIP2, DPP10, HLA-G, GRPA, y PHF11 (figura 22). Finalmente, los estudios de expresión génica han contribuido a la confirmación de observaciones previas o a la aportación de nuevos puntos de estudio en las vías metabólicas implicadas en la fisiopatología $[112,116]$

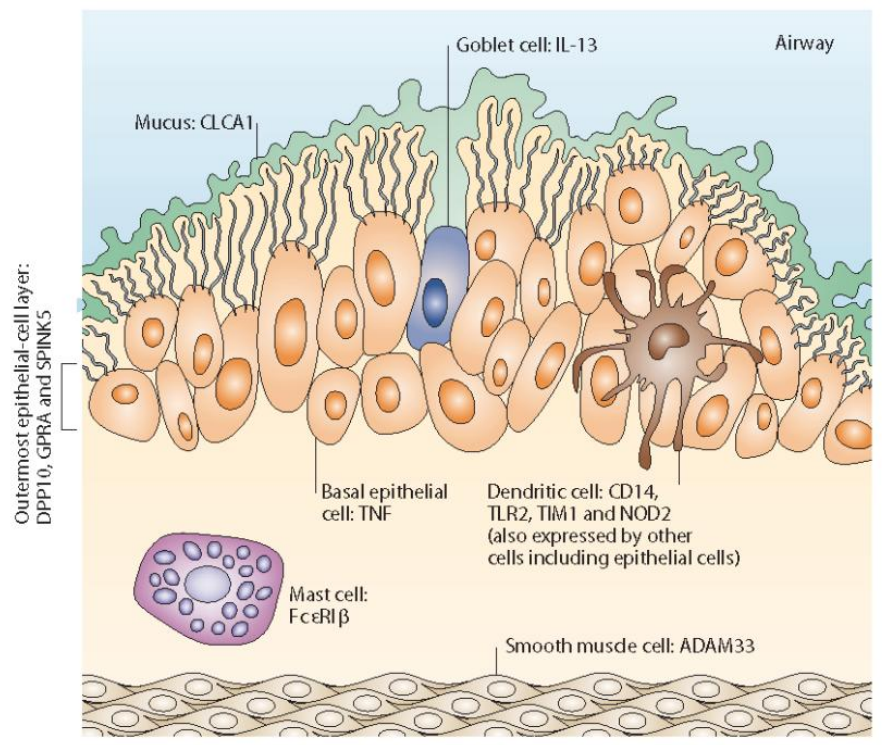

Figura 22. Localización epitelial de algunos de los genes asociados al asma [116].

Actualmente, de los más de 120 genes cuya asociación con el asma o fenotipos relacionados ha sido publicada, la mitad aproximadamente han podido ser replicados en otros estudios. Los más replicados son los de las citocinas IL-13 y IL-4, del receptor de IL-4 (IL-4RA), del receptor $\beta 2$-adrenérgicos (ADRß2), del antígeno leucocitario humano DRB1 (HLA-DRB1), del factor de necrosis tumoral (TNF- $\alpha$ ), de la linfotoxina- $\alpha$ (LTA), del receptor de alta afinidad para la lgE (FcعRI) y la metaloproteasa ADAM33. Su distribución se extiende por casi la totalidad del genoma a excepción del cromosoma 23. 


\section{CROMOSOMA 1}

IL10: Gen que codifica la citocina IL-10 cuyas variantes génicas han presentado asociación con el asma [117].

FLG: Gen de la filagrina, expresada en la epidermis y en las mucosas oral y nasal [118] que forma parte del complejo de diferenciación epidérmico localizado en el cromosoma 1q21. Se ha relacionado con la dermatitis atópica y el eczema [119] así como con la gravedad del asma asociada a dermatitis atópica [120].

\section{CROMOSOMA 2}

ÍL $\mathbb{R} R$ : Gen perteneciente a la agrupación del gen IL-1 en $2 q 14$, que sintetiza la proteína antagonista del receptor de la IL-1, citocina relevante en el equilibrio entre el estado pro y anti-inflamatorio. IL-1RN se asoció al asma a través de 3 polimorfismos en una población alemana y de otros 2 distintos en familias italianas [112].

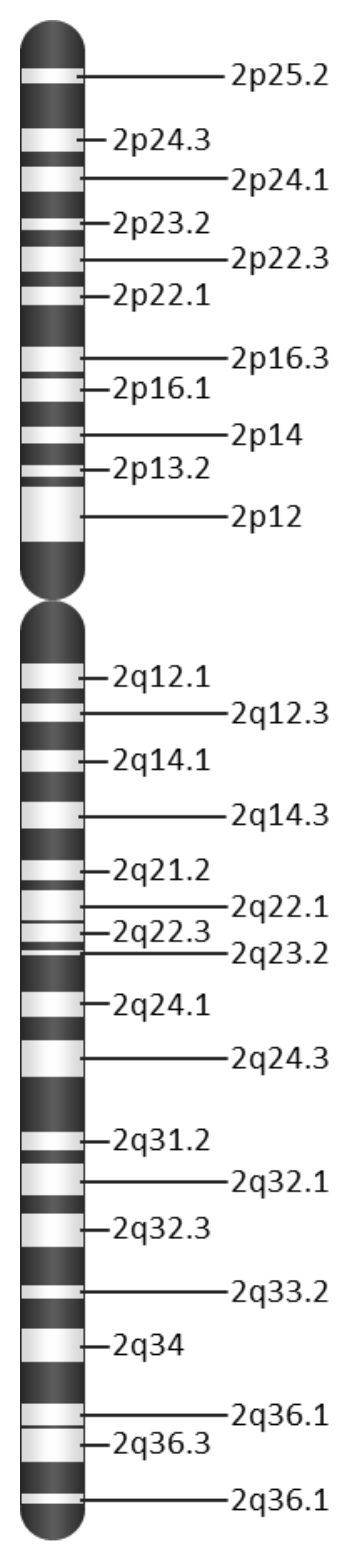

DPP10: Codifica la dipeptidil-dipeptidasa 10, implicada en el procesamiento de los péptidos terminales de citocinas y quimiocinas. Su localización comprende una amplia región entre $2 q 14$ y 2q32, próxima a la agrupación del gen de la 
IL-1, y que se determinó como una región ligada al asma y a la hiperreactividad bronquial [121].

\section{CROMOSOMA 5}

IL -5: La citocina IL-5 ha sido analizada en diversos estudios genéticos por participar en la maduración de los eosinófilos mediante su unión a la cadena alfa del receptor de IL-5 presente en estas células y, por tanto, en el proceso inflamatorio de la alergia. De hecho en estas investigaciones se determinó la asociación de variantes de $I L-5$ y de su receptor, con el asma y sus síntomas [122], aunque dicha asociación no ha resultado tan contundente como la existente con otros genes característicos de la respuesta Th2.

IL -4: Gen perteneciente a la agrupación (cluster) de citocinas del $5 q$, asociado al asma y la alergia a través de sus variantes génicas en diferentes estudios [123]. Asociación esperada teniendo en cuenta la implicación de IL-4 en la orientación de la

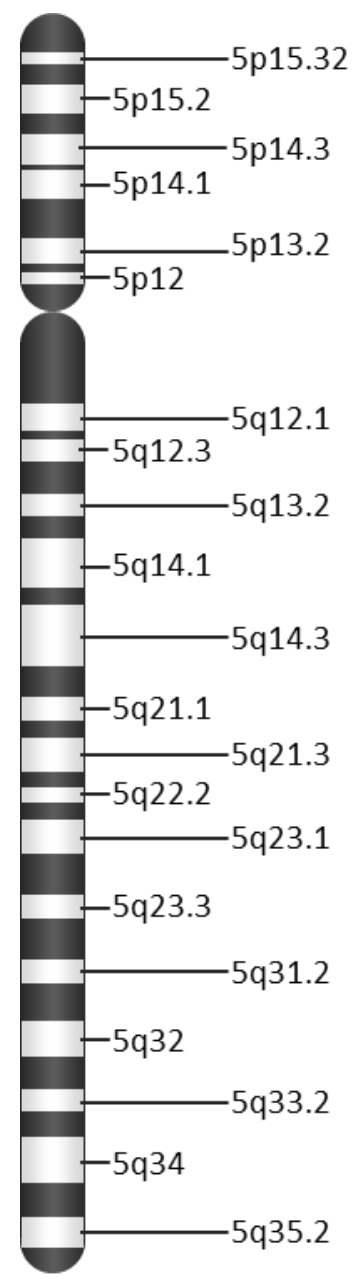
maduración linfocitaria de los CD4+ hacia linfocitos Th2.

IL -13: Gen de la citocina IL-13, inductora de la síntesis de $\lg E$ y uno de los más estudiados en relación a esta patología. El cambio Arg130Gln en 
la secuencia de aminoácidos a causa del polimorfismo IL-13 +2044G>A provoca un aumento en su actividad; lo que explica la asociación de esta variante con niveles elevados de IgE total, asma, atopia y dermatitis atópica [124]. También se ha asociado con un aumento del riesgo de desarrollar sensibilización alérgica a través de un segundo polimorfismo en la región promotora del gen: $1112 \mathrm{C}>\mathrm{T}$, que se traduce en una mayor tasa de transcripción [125].

CD14: Algunos polimorfismos del gen que codifica al receptor del lipopolisacárido CD14 ha sido asociado a la inflamación alérgica y la regulación de $\lg E$ [126]; entre otros genes responsables de la respuesta inmune innata.

SPINK5: La proteína SPINK5 (Serine Protease Inhibitor Kazal-type 5), exclusiva del epitelio, tiene una función protectora respeto a las proteasas de los mastocitos. El cambio en la secuencia de aminoácidos Glu420Lys, rs230307 se ha asociado con el asma y el eczema [127].

ADR B2: El gen del receptor adrenérgico $\beta 2$ es uno de los genes asociados al asma que mejor han sido replicados [128]. Por otro lado, es candidato a estudios farmacogenéticos debido a su participación en la respuesta a determinados tratamientos [129].

CYFíp2: Conocido como el gen de la proteína 2 que interacciona con la proteína citoplasmática FMRP (Citoplasmic fragile $X$ mental retardation protein), se encuentra en la región $5 q 33$, fuertemente ligada al asma. Podría estar relacionado con la diferenciación de linfocitos $T$, ya que su expresión se encuentra incrementada en los linfocitos de pacientes homocigotos para un determinado haplotipo [130]. 


\section{CROMOSOMA 6}

TNF: La asociación del gen codificante del factor de necrosis tumoral al asma es otra de las que mejor han sido replicadas en los estudios [131].

LT-A: Asociado al asma y responsable de la síntesis de la linfotoxina a (LT-A) [131].

HLA III: También ha quedado de manifiesto el importante papel que juega la presentación antigénica en las respuesta alérgica dependiente de IgE, mediante estudios que muestran una asociación relevante con los alelos $D R, D Q$ y $D P$ del complejo principal de histocompatibilidad de clase II [132].

HLA C G: HLA-G es una molécula de clase I del complejo principal de histocompatibilidad. El gen se encuentra localizado en la región 6 p21,

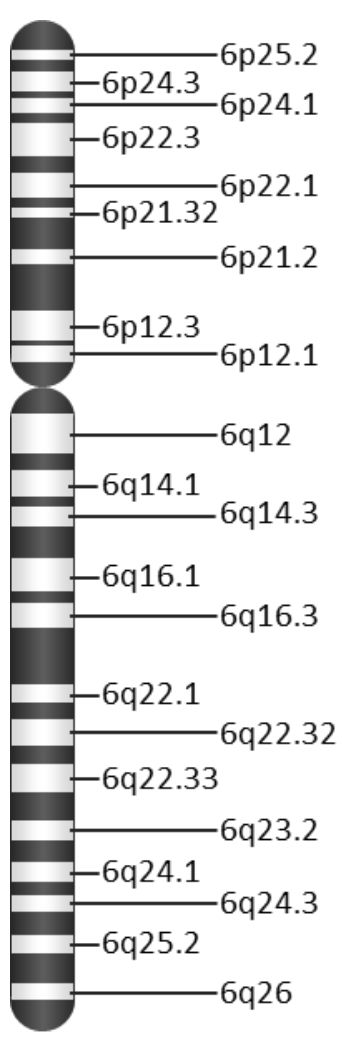
ampliamente ligada al asma y fenotipos relacionados; se presenta como un gen de susceptibilidad para el asma y la hiperreactividad bronquial [133].

\section{CROMOSOMA 7}

GRPA: El gen GRPA, presente en la región 7p15p14, asociada al asma y la atopia [134], pertenece 
a un receptor acoplado a proteína G. Los estudios funcionales llevados a cabo posteriormente han proporcionado datos sobre su posible implicación a nivel de la regulación del crecimiento celular, relacionada con la remodelación de las vías respiratorias en el asma [135].

\section{CROMOSOMA 10}

GATA3: El factor de transcripción GATA3 actúa en la inducción de los linfocitos T hacia el linaje Th2. De hecho, tiene como inhibidor una citocina promotora de la respuesta Th1, como es la IL-12, que actúa impidiendo su interacción con el ADN a través de una interacción proteína-proteína con el TGFB1. Los polimorfismos presentes en este gen se han asociado al asma y la alergia en varios estudios [136].

\section{CROMOSOMA 11}

FCER1: El polimórfico gen que codifica la cadena $\beta$ del receptor de alta afinidad de la lgE, FcER1 (FCER1B), es uno de los genes de susceptibilidad al asma que ha sido más replicado [115] y que tradicionalmente explicaba el ligamiento de la región 11 q13 al asma. Estas pequeñas variaciones en su secuencia se podrían traducir en cambios en su expresión y en la consecuente desgranulación de los mastocitos a través de la interacción con la $\lg E$.

GENES GST: Son genes de las Glutation-S-transferasas (GSTP1 y GSTM1), cuyos polimorfismos se han asociado con el asma, la atopia y la función pulmonar [137]. 


\section{CROMOSOMA 12}

STAT6: La proteína STAT6 (Signal Transducer and Activator of Transcription 6) pertenece a la ruta de transmisión de señales de la IL-4 en la activación hacia la respuesta Th2. Se han asociado polimorfismos de este gen con el asma y la alergia [136].

VDR: La asociación del asma con el gen del receptor de la vitamina $D$ ha sido controvertida, sin embargo los trabajos con modelos experimentales [138] y los estudios de expresión revelan la importancia del sistema endocrino de

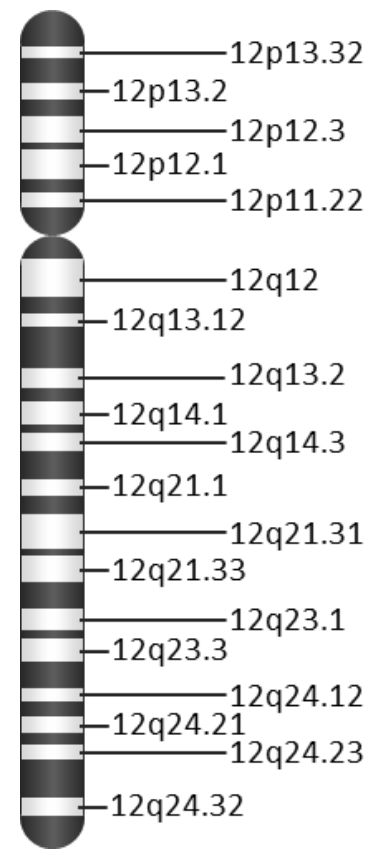
la vitamina $D$ en la respuesta Th2, promotora de la inflamación en las vías respiratorias.

\section{CROMOSOMA 13}

PHF11: Fue identificado mediante un estudio de ligamiento en el que se descubrió un nuevo QTL tras identificar una asociación de niveles elevados de $\lg E$ con un microsatélite de la región $13 q 14$ hasta ese momento irrelevante. Algunas de sus variantes génicas se han asociado con la gravedad del asma [139]. Codifica una proteína de la familia PHD (Plant Homeodomain), que interacciona con las histonas y modifica la transcripción génica gracias a los dos dedos de zinc que posee en su estructura [140].CROMOSOMA 14 
PTGDR: Gen del receptor de prostaglandinas D2 (DP), expresado en mastocitos y eosinófilos. Surgió a partir de la asociación de un marcador de ADN muy cercano a él que presentó ligamiento con niveles elevados de lgE en suero [141]. Su análisis, objeto de este estudio, será abordado en detalle más adelante.

\section{CROMOSOMA 19}

TGFB1: El gen codificante de la citocina inmunorreguladora TGFB1 (Transforming Growth Factor-B), al igual que el de la IL-10, ha sido asociado con el asma [117].

\section{CROMOSOMA 20}

ADAM33: El gen de la metaloproteasa ADAM33 fue identificado como responsable de la señal de ligamiento a partir del análisis posicional de una región en el brazo corto del cromosoma 20 que presentó un ligamiento significativo con el asma y la hiperrreactividad bronquial [142]. Otros estudios de asociación o análisis de haplotipos confirmaron

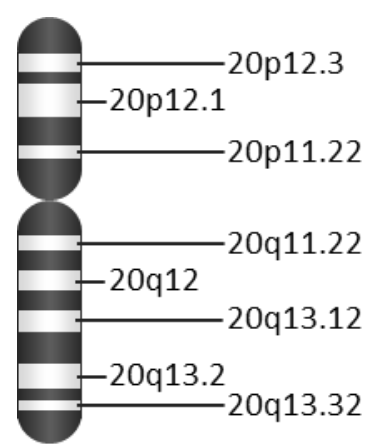
posteriormente estos resultados $[143,144]$, del mismo modo que se han replicado por distintos grupos, considerándolo un gen de susceptibilidad para el asma en diferentes poblaciones [145]. Sin embargo, en los estudios de asociación con los polimorfismos sí se han encontrado diferencias poblacionales en cuanto a las variantes que presentaban asociación [146]. 
Su función proteolítica en la transmisión de señales extracelulares ha propuesto su participación en la remodelación de las vías respiratorias característica de la patogénesis del asma [147].

\section{EPIGENETTICA Y ASMA}

La epigenética, que se define como el conjunto de cambios en la expresión génica heredables que se producen sin alterar la secuencia de ADN, se ha estudiado recientemente para explicar las interacciones entre genes y factores ambientales que caracterizan al asma [148]. Los estudios recientes plantean que la variedad fenotípica de los pacientes en cuanto a la sintomatología y el curso de esta enfermedad podrían deberse a cambios epigenéticos; entre los cuales destacan:

METiLACí́N DEL ADN: Es uno de los mecanismos epigenéticos en el cual un grupo metilo se une covalentemente a un residuo de Citosina seguida de Guanina en la secuencia de ADN, conocido como sitio CpG. Estos sitios se agrupan próximos a las regiones promotoras de los genes formando las islas CpG y regulan la expresión génica a través de su estado de metilación [148]. Las regiones de la cromatina asociadas con el ADN hipometilado permiten la expresión de genes, mientras que el ADN hipermetilado está empaquetado en la cromatina inactiva [149].

MODiFíCACiÓN POSTRADVCCIONAL DE HiSTONAS: Estas proteínas responsables del esqueleto cromatínico sufren un complejo patrón de modificaciones múltiples y simultáneas como acetilación, metilación, fosforilación, y ubiquitinación, que se conoce como código de histonas [150]. Así como la metilación del ADN, estas modificaciones están dirigidas a modular la estructura y la estabilidad de la cromatina, en definitiva, el acceso 
de los factores de transcripción a la misma y, por tanto, al silenciamiento o a la activación de los genes [151].

A partir de los estudios de los efectos de las exposiciones ambientales y otros factores desencadenantes del asma se han establecido períodos de tiempo concretos en los que habría una mayor susceptibilidad a los mismos, como son el desarrollo prenatal, la primera infancia y la adolescencia; en los cuales las modificaciones epigenéticas serían determinantes a la hora de desarrollar la enfermedad (figura 23) [148].

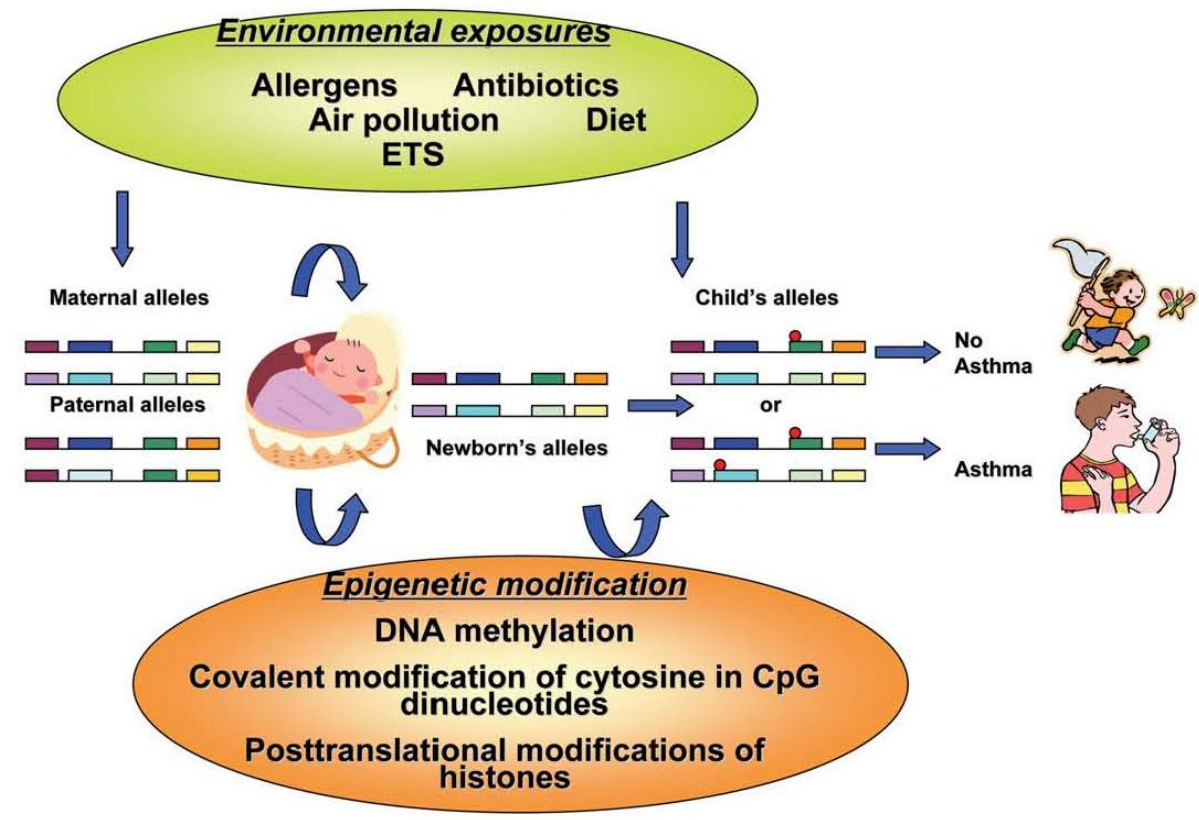

Figura 23. Interacciones entre epigenética y factores ambientales. ETS: exposición al humo del tabaco. Los puntos rojos sobre los alelos simbolizan los cambios epigenéticos [148].

Estudios in vitro arrojan datos importantes demostrando que la metilación del ADN de los genes críticos para los linfocitos Th pueden inducir la diferenciación hacia un fenotipo alérgico [148]. [152]. 
A pesar de los numerosos resultados en este campo, es fundamental seguir trabajando sobre la susceptibilidad al desarrollo de asma en cuestiones como la influencia del momento de la exposición a los factores ambientales, la dosis de exposición, la dieta y la etnia [148].

\section{FARMACOGENETTíCA EN EL TRATAMIENTO DEL ASMA}

Inicialmente el término farmacogenética se utilizó a raíz de la propuesta de Fredrich Vogel y Arno Motulsky en la cual la respuesta a los medicamentos sería el resultado de las variaciones de los genes responsables de su biotransformación [153]. De manera que la palabra farmacogénetica definía el estudio de los aspectos de la variabilidad genética asociados a la diversidad en la respuesta a los medicamentos entre individuos o poblaciones. El término farmacogenómica sin embargo, se ha incorporado más recientemente a nuestro léxico. Son conceptos que van unidos, y con relativa frecuencia encontramos autores que los emplean indistintamente. Sin embargo según las agencias europea (EMEA: European Medicines Agency) [154] y americana (FDA: Food and Drug Administration) [155] del medicamento, la farmacogenómica recoge las variaciones del $A D N$ y del $A R N$ relacionadas con la respuesta a medicamentos, y la farmacogenética, la influencia de las variaciones del ADN en la respuesta a medicamentos.

Las características farmacocinéticas (absorción, distribución, metabolización y excreción) y farmacodinámicas (mecanismos de acción y efectos de los fármacos, tanto en la interacción fármaco-receptor como en acciones postreceptor) de la respuesta a un fármaco son reflejo de la variabilidad interindividual [156]. 
El estudio de los genes relacionados con el metabolismo o la acción de determinados medicamentos se ha planteado en los últimos tiempos como una poderosa herramienta incluso en la rutina asistencial para individualizar el tratamiento y seleccionar el fármaco a prescribir o la dosis más apropiada según un determinado perfil genético; lo cual reportará mayores beneficios y minimizará los efectos no deseables $[157,158]$. Se habla de la eficacia de la farmacogenética.

El objetivo principal del tratamiento del asma es lograr y mantener el control de la enfermedad lo antes posible, además de prevenir la obstrucción crónica al flujo aéreo y los episodios agudos, mantener los niveles de actividad del individuo, incluyendo los referentes al ejercicio físico e incluso mejorar la función pulmonar; todo ello evitando la aparición de los posibles efectos adversos de los fármacos [3]. La estrategia terapéutica que se sigue actualmente es la de iniciar el tratamiento de una forma más agresiva con el fin de controlar la sintomatología e ir disminuyendo poco a poco las dosis para minimizar los efectos no deseados sin sacrificar la eficacia terapéutica [159]. Para ello se dispone de cuatro grupos de fármacos como son: $\beta 2$-agonistas inhalados (albuterol, salmeterol y formoterol, etc); glucocorticosteroides de uso sistémico o inhalado (beclometasona, budesonida, fluticasona, y prednisona); teofilina y sus derivados, y por último; modificadores de los leucotrienos cisteinílicos (molekulast, pranlukast, zafirlukast y zileuton).

La variabilidad en la respuesta al tratamiento del asma es muy elevada, tal y como ocurre en el resto de las enfermedades del aparato respiratorio [160]. Una de las causas de respuestas no óptimas de los tratamientos es la falta de cumplimiento, la existencia de un variado grupo de factores ambientales y los polimorfismos recientemente identificados de genes asociados con la respuesta a los distintos grupos de fármacos empleados en asma [161], como el gen del 
receptor de corticotropina, CRHR1 [162] y el gen que codifica el receptor $\beta 2$ adrenérgico, $A D R B 2$ [161]; que podrían influir en la respuesta al tratamiento de esta patología con corticoides y beta-agonistas respectivamente. La aportación de la farmacogenética y la farmacogenómica es la mejora de la eficacia de los tratamientos al personalizar la terapia gracias a la información genética; reduciendo a la vez los costes económicos que supone la enfermedad.

\subsection{PTGDR Y ASMA}

\section{PROSTAGLANDINA $D_{2}$}

La prostaglandina $D_{2}\left(P_{G}\right)$ pertenece a un grupo de mediadores lipídicos de función autocrina y paracrina derivados del ácido araquidónico [163]. Interviene en procesos relacionados con el sueño, la temperatura corporal, el olfato y la liberación de hormonas a nivel del sistema nervioso central (SNC); mientras que a nivel periférico inhibe la agregación plaquetaria, promueve la vasodilatación, la relajación de la musculatura lisa, la constricción pulmonar y la broncoconstricción [164]. Por otro lado, es el principal prostanoide liberado por los mastocitos activados en la respuesta inmune [165], y se considera un importante mediador inflamatorio de las vías respiratorias en las enfermedades alérgicas como el asma, la rinitis alérgica y la dermatitis atópica [166].

La síntesis de prostaglandina $D_{2}$ se inicia por la fosfolipasa $A_{2}$ que cataliza la hidrólisis del ácido araquidónico de los fosfolípidos de la membrana plasmática a partir de estímulos fisiológicos o patológicos [167]. La acción enzimática de las cicloxigenasas 1 y 2 (COX-1 y COX-2) sobre el ácido araquidónico produce un endoperóxido cíclico, $\mathrm{PGG}_{2}$ y a partir de éste un intermedio inestable, $\mathrm{PGH}_{2}$ 
(figura 24). Mientras que la COX-1 tiene una expresión constitutiva en muchos tipos celulares y tejidos, la expresión de COX-2 es inducible por distintos estímulos inflamatorios mediados por citocinas proinflamatorias, estrés mecánico, lípidos oxidados, radicales libres o productos bacterianos [168]. La $\mathrm{PGH}_{2}$ es sustrato de las distintas sintetasas que generan inmediatamente el conjunto de prostanoides, tromboxanos y prostaglandinas, entre ellas la $P G D_{2}$ (figura 24). La expresión predominante de estas enzimas en los distintos tipos celulares determina el conjunto de prostanoides sintetizados en cada situación fisiológica o patológica [169].

Existen dos isoformas de la sintasa de la prostaglandina $D_{2}$ (PGDS), la hematopoyética (H-PGDS) y la tipo lipocalina (L-PGDS) (figura 24). Las dos enzimas son bastante diferentes entre sí en secuencia aminoacídica, estructura terciaria, origen evolutivo, expresión celular y tisular, localización cromosómica y función. La L-PDS es una proteína secretora sintetizada por células meníngeas, células epiteliales del plexo coroideo y oligodendrocitos del cerebro así como algunos tipos celulares concretos del aparato reproductor masculino. La HPGDS, conocida también por ser la única glutatión S-transferasa de tipo sigma presente en vertebrados, es una proteína citosólica responsable de la síntesis de $\mathrm{PGD}_{2}$ en células inmunes e inflamatorias como los mastocitos, los basófilos o las células dendríticas y en algunas células de la estirpe Th2 [170].

La actuación y funciones biológicas de la $\mathrm{PGD}_{2}$ están mediadas por los receptores transmembranarios específicos, PTGDR y CRTH2 pertenecientes a la superfamilia de receptores asociados a proteínas G heterotriméricas [168]. Además, la $\mathrm{PGD}_{2}$ también se une al receptor de tromboxano $A_{2}$, TP y a uno de los receptores de la prostaglandina $\mathrm{PGE}_{2}, \mathrm{EP} 3$ [171]. Por otro lado, algunos metabolitos de la $P G D_{2}$ como la 15 -deoxi- $\Delta^{12,14}-\mathrm{PGJ}_{2}$ pueden participar en actividades intracelulares interaccionando con factores de transcripción mediante 
su unión a receptores nucleares PPAR (receptor gamma activador de la proliferación peroxisomal) o por mecanismos independientes a ellos [166, 169]. Sin embargo las concentraciones de estos metabolitos necesarias para observar dichas funciones son muy superiores a las que se dan in vivo [172].

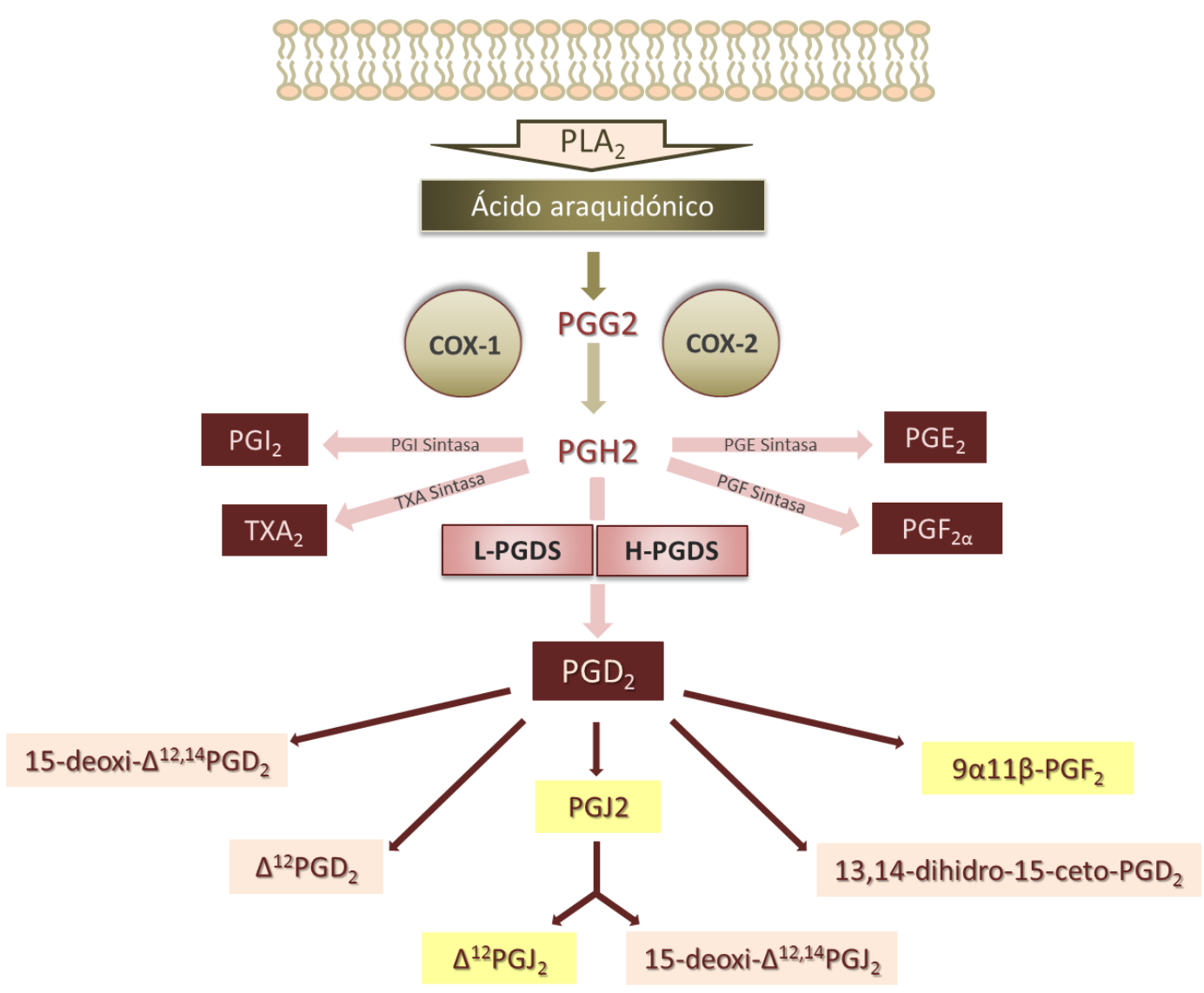

Figura 24. Esquema del metabolismo de $\mathrm{PGD}_{2 .}\left(\mathrm{PGI}_{2}\right.$ : prostaglandina $I_{2}, \mathrm{TXA}_{2}$ : tromboxano $A_{2}, P G E_{2}$ : prostaglandina $E_{2}, P G F_{2 a}$ : prostaglandina $F_{2 \alpha}$. Sobre fondo amarillo se representan los principales metabolitos de la prostaglandina $D_{2}$.

\section{RECEPTOR PTGDR}


El receptor de $\mathrm{PGD}_{2}$ conocido como receptor prostanoide $\mathrm{D}$ (PTGDR) o receptor prostanoide D1 (PTGDR1) es codificado por el gen PTGDR localizado en el brazo corto del cromosoma 14 (14q22.1), al que también se hace referencia en la literatura como $D P, D P 1, P T G D R 1$ AS1 o ASTR1.

\section{ESTR VCTVRA}

La molécula del PTGDR está constituida por 359 aminoácidos y su masa molecular es de 40,276 kDa [164]. Posee siete dominios transmembranarios, estructura característica de los receptores asociados a proteínas G heterotriméricas para la transducción de señales; de hecho, comparte cierta identidad a nivel aminoacídico con miembros de la familia de los receptores de tipo rodopsina (figura 25) [173]

Presenta tres posibles sitios de N-glicosilación, concretamente en los residuos de asparragina (Asn) de las posiciones 10, 90 y 297 de su secuencia de aminoácidos; localizados en el extremo amino terminal, y en el primer y tercer lazos extracelulares respectivamente. También contiene dos sitios susceptibles de fosforilación por la proteína cinasa C (PKC) localizados en los dos primeros lazos citoplasmáticos correspondientes a los aminoácidos serina (Ser) y treonina (Thr) de las posiciones 50 y 145 de su secuencia. Por otro lado se describen otros seis sitios potenciales de fosforilación en residuos de Ser y Thr en el extremo carboxilo terminal del receptor, que podrían estar implicados en su desensibilización y, por tanto, en su capacidad homeostática en los procesos de activación celular [164]. 


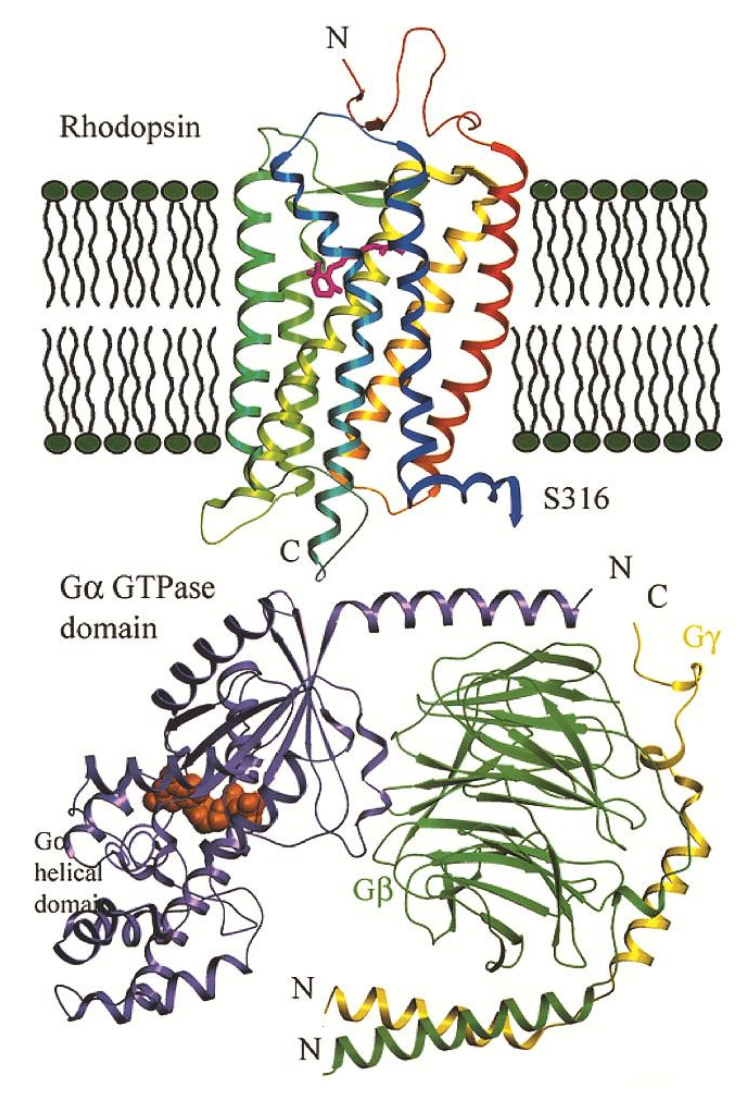

Figura 25. Representación de un receptor asociado a proteínas $\mathrm{G}$ basada en su estructura tridimensional. Se representan las 3 subunidades que componen una proteína $\mathrm{G} ; \alpha, \beta$ y $\gamma$, acopladas al receptor con los siete dominios transmembrana que en este caso es la rodopsina ( $\mathrm{N}$ : extremo amino terminal, C:extremo carboxilo terminal) [174].

Mediante estudios filogenéticos por homología de secuencia con otros miembros de la familia de receptores de prostanoides se ha comprobado un alto grado de similitud con IP, receptor de la prostaglandina $I_{2}$ y con EP2 y EP4, dos receptores de la prostaglandina $E_{2}$. De las tres categorías en que se agrupan los receptores de prostanoides, DP pertenece a la primera, compuesta por los receptores relajantes, los cuales, en general, están acoplados a una proteína G estimuladora como Gs (figura 26) [175]. 


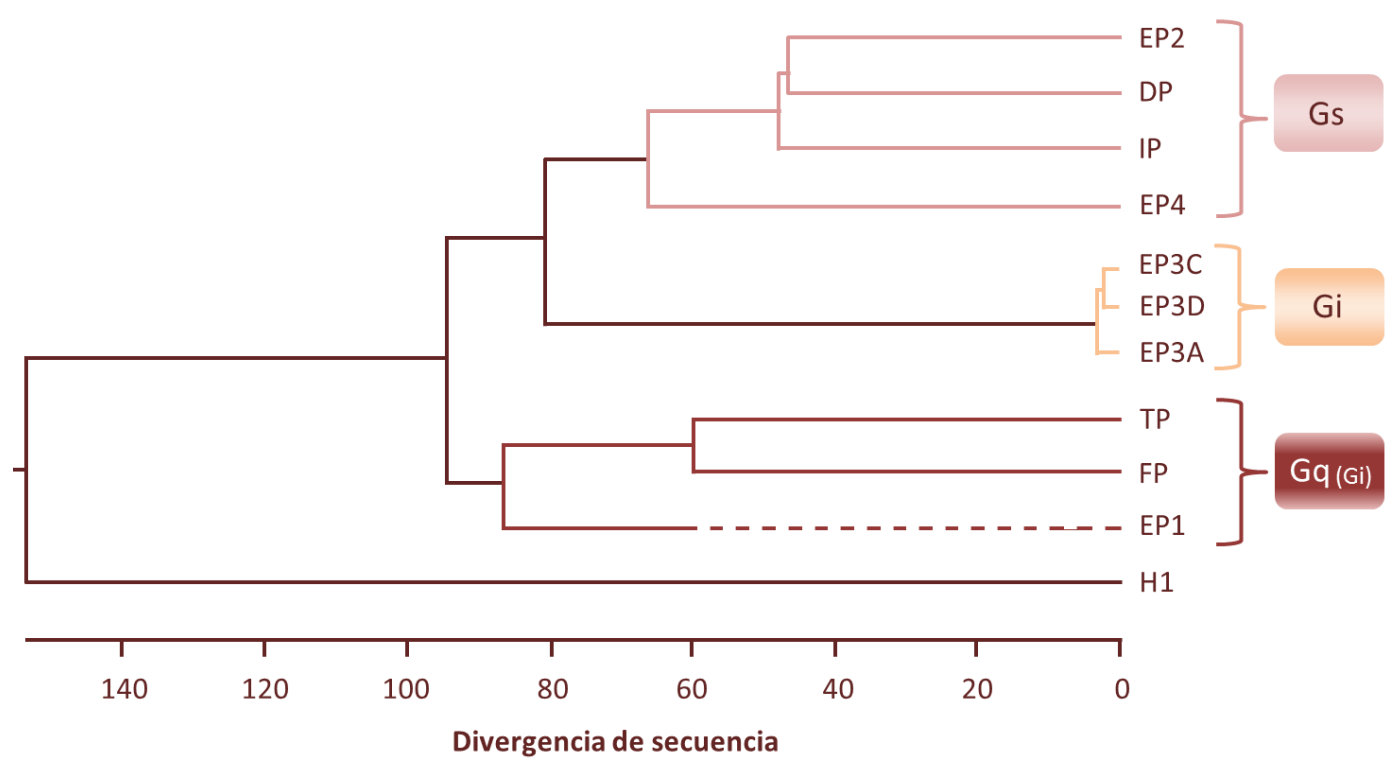

Figura 26. Árbol filogenético de los receptores de prostanoides. Basado en el Método Clustal con la tabla de pesos residuales PAM250. (EP1, EP2, EP3C, EP3D, EP3A, EP4: receptores de $P E_{2}$, IP: receptor de $P \mathrm{Pl}_{2}$, TP: receptor de $\mathrm{TXA}_{2}, \mathrm{FP}$ : receptor de $\mathrm{PGF}_{2 \alpha}, \mathrm{H} 1$ : receptor 1 de la histamina). Véase que el receptor $\mathrm{CRTH} 2$ no aparece en esta representación por encontrarse filogenéticamente alejado de ellos [175].

\section{FVNCiீ์}

PTGDR es activado por la $\mathrm{PGD}_{2}$ y por algunos de sus metabolitos incluyendo $\Delta^{12}-\mathrm{PGD}_{2}$ y $P \mathrm{PJ}_{2}[176]$, si bien estos productos metabólicos son poco activos frente a este receptor [166]. La selectividad en la unión a DP parece estar determinada por los tres primeros dominios transmembranarios [167]. Por otro lado, en muchos estudios se emplean distintos compuestos que se comportan como agonistas o antagonistas del mismo. Destacan BW245C, agonista selectivo de PTGDR y con una afinidad de unión incluso algo superior a la de la propia $\mathrm{PGD}_{2}$ [164]; y BW868C, MK-0524 y S-5751 entre los antagonistas también selectivos de PTGDR [171]. 
La activación de este receptor trae consigo la elevación intracelular del mensajero adenosín monofosfato cíclico (AMPc) [164, 177]. El AMPc es sintetizado a partir de adenosín trifosfato (ATP) por la enzima adenilato ciclasa (AC), localizada en la membrana celular y activada por la subunidad a de la proteína Gs, a la cual se encuentra acoplada PTGDR (figura 27). Este incremento de $\mathrm{AMPc}$ en la célula implicaría la activación de la proteína cinasa $\mathrm{A}$ (PKA), sin embargo no hay datos que confirmen esta ruta en el caso de PTGDR [175], de hecho, en determinados tipos celulares como linfocitos NK y células dendríticas se ha comprobado que la transmisión de señales vía DP es independiente de PKA [177].

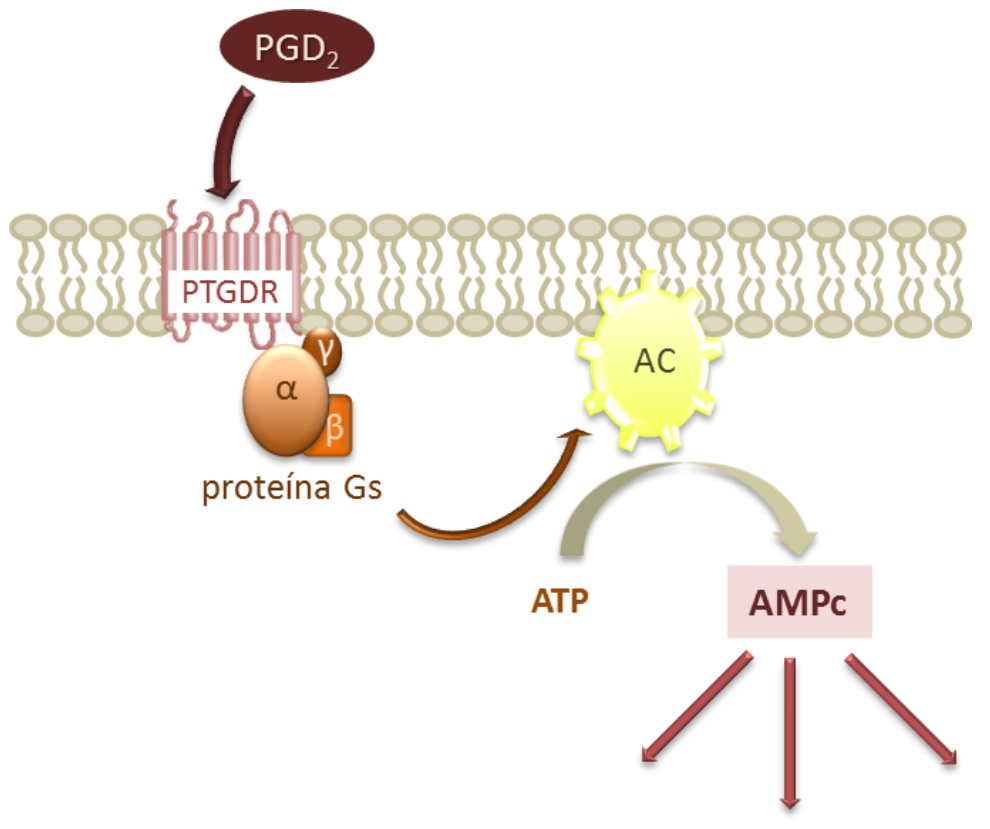

Figura 27. Ruta de transmisión de señales de PTGDR. (AMPc: adenosín monofosfato cíclico, ATP: adenosín trifosfato, AC: adenilato ciclasa).

En función de la señal y el tipo celular el AMPc puede potenciar o suprimir la participación del calcio $\left(\mathrm{Ca}^{2+}\right)$ en la transducción de la señal [177]. Se ha descrito tanto la elevación transitoria de la concentración de $\mathrm{Ca}^{2+}$ dentro de la célula en la transmisión de señales a través de PTGDR $[164,178]$ como la inhibición de la 
movilización por este mensajero de los depósitos intracelulares y la entrada extracelular [177]. Por otro lado, la estimulación de PTGDR podría provocar la activación de la proteína lipasa C (PLC) y la proteína cinasa C (PKC) y con ello otra ruta de transducción de la señal $[175,176]$.

Pese a que PTGDR en un receptor poco abundante, su expresión no se limita a las células hematopoyéticas e inflamatorias como en el caso del CRTH2. Se localiza en linfocitos NK, Th1 y Th2, células dendríticas, eosinófilos, neutrófilos y basófilos; de hecho algunas de ellas co-expresan los dos receptores. También se encuentra en la superficie de plaquetas, en células y regiones concretas del SNC, músculo liso, células epiteliales ciliadas y no ciliadas de los bronquiolos y células epiteliales alveolares de tipo II y tipo I, aunque en este último tipo celular la expresión de DP es moderada [167, 179]. La activación de este receptor por la $\mathrm{PGD}_{2} \mathrm{O}$ sus agonistas promueve la relajación de la musculatura lisa, la vasodilatación, la secreción mucosa[166, 173] y la disminución de la tensión ocular [180], induce el sueño de ondas lentas [167, 181] y participa en la regulación de la percepción del dolor [182], inhibe la agregación plaquetaria [183] y juega un papel importante en la respuesta inmune en las enfermedades alérgicas.

\section{ASOCIACIÓN CON EL ASMA}

Como se ha dicho, el proceso asmático se caracteriza por una inflamación debida a la secreción de diferentes compuestos intermediarios que promueve la acumulación de células Th2, eosinófilos y basófilos. Entre estos compuestos intermediarios, la $\mathrm{PGD}_{2}$ es el metabolito del ácido araquidónico más abundantemente producido en respuesta a alérgenos ambientales [179]. En los individuos asmáticos, los niveles de este prostanoide y su principal metabolito 
$9 \alpha, 11 \beta-\mathrm{PGF}_{2}$ se disparan en cuestión de minutos tras la exposición al alérgeno, aumentando hasta 150 veces en el líquido de lavado broncoalveolar (LBA, BAL: Bronchoalveolar Lavage) por encima del nivel previo a la exposición [165, 176]. Del mismo modo se detecta la elevación de este producto metabólico en la orina de pacientes con asma inducida por aspirina y otros antiinflamatorios no esteroideos tras la provocación bronquial con estos compuestos [184]; y en esta misma muestra de pacientes asmáticos sometidos a inhalación de manitol, causante de broncoconstricción en estos individuos mediada por mecanismos similares a los del asma inducida por el ejercicio físico [185].

Se ha comprobado que la activación de los mastocitos es necesaria para que sinteticen y secreten $P G D_{2}$, y que son los responsables del grueso de su producción en la respuesta alérgica; pese a que otras células como los linfocitos Th2, células dendríticas, macrófagos, fibroblastos, células del músculo liso bronquial y células epiteliales también tienen esa capacidad [176]. De hecho se ha propuesto a la $\mathrm{PGD}_{2}$ como un marcador de activación de mastocitos en el asma [186].

Se ha descrito que la exposición a los alérgenos estimula la producción de $\mathrm{PGD}_{2}$ en la mucosa nasal de los pacientes con rinitis alérgica [187], y en la piel de aquellos que padecen dermatitis atópica [188]. En individuos afectados de rinitis alérgica, el contacto con el alérgeno promueve de manera inmediata la síntesis de esta prostaglandina. A través de PTGDR aumenta el flujo sanguíneo nasal; de hecho, la administración intravenosa de $\mathrm{PGD}_{2}$ en voluntarios produce un intenso enrojecimiento facial y congestión nasal sin otros efectos sistémicos o a nivel pulmonar. En modelos animales de rinitis se ha comprobado esta función promotora de la vasodilatación y formación de edema vía DP [166]. 
Las respuestas biológicas que se atribuyen a este prostanoide en la patología asmática son la broncoconstricción, secreción mucosa, vasodilatación, aumento de la permeabilidad vascular y quimiotaxis de células inflamatorias, especialmente de células Th2, así como la modulación de la producción y secreción de citocinas y quimiocinas; todas ellas mediadas por sus receptores PTGDR, CRTH2 y TP.

La interacción de la $\mathrm{PGD}_{2}$ con PTGDR promueve la acumulación de AMPc, que, en general, se asocia con la inhibición de la función efectora de linfocitos Th1, células NK y otras células inmunes [169]. A través de la transmisión de señales por este receptor se inhibe la producción de IL-2 y IFN-y en células T $\mathrm{CD}^{+}$y $\mathrm{CD}^{+}$[189] y de IL-12 en las células dendríticas [190]. La migración y las funciones de los linfocitos NK, promotores de la respuesta inmune de tipo Th1 también resultan inhibidas vía DP [177]. Por otro lado, a partir de la interacción de la $\mathrm{PGD}_{2}$ con el receptor $\mathrm{CRTH} 2$ se promueve el reclutamiento y activación de células Th2, eosinófilos y basófilos [191, 192]; así como la producción de citocinas Th2 (IL-4, IL-5 e IL-13) por dichos linfocitos [193]. A través de PTGDR la prostaglandina $D_{2}$ suprimiría la respuesta Th1 y promovería un entorno favorable para la polarización de las células T a Th2 [194] lo cual, coordinado con la acción de CRTH2, llevaría al estado Th2 dominante característico de la inflamación alérgica [176] (figura 28).

Otras de las funciones atribuidas a PTGDR son la vasodilatación y el aumento de la permeabilidad vascular que facilitan la extravasación de células inflamatorias [195]; la secreción de moco [173], un aumento de la supervivencia de los eosinófilos [196] e incluso de más tipos celulares como los linfocitos Th2 y mastocitos [197] y la estimulación de las células epiteliales para la producción de la quimiocina derivada de los macrófagos (MDC o CCL22) [195, 196], que induce el reclutamiento y la activación de linfocitos Th2 [195], y para la síntesis de los 
metabolitos del ácido araquidónico, entre ellos la propia $\mathrm{PGD}_{2}$, a través de un mecanismo autocrino mediado por DP [176].

La $\mathrm{PGD}_{2} \mathrm{y}$, por tanto, sus receptores constituirían un importante nexo entre la respuesta inmune inmediata y la respuesta inmune tardía frente a los alérgenos, dirigiendo los procesos celulares iniciales de la respuesta inmune al reclutamiento y activación de Th2, eosinófilos y resto de células inflamatorias con los consiguientes efectos fisiopatológicos asociados (figura 28) [176].

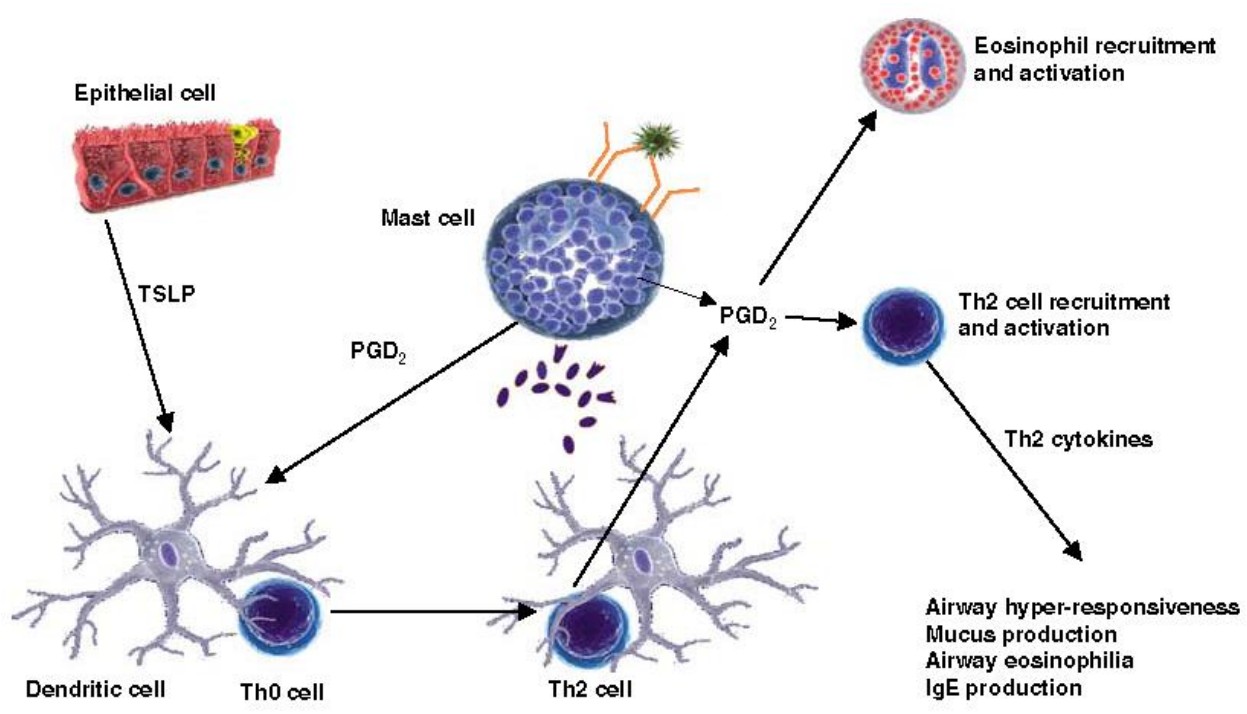

Figura 28. Esquema propuesto de la acción de $\mathrm{PGD}_{2}$ a través de PTGDR y CRTH2. Inhibición de la producción de IL-12 por las células dendríticas y activación y reclutamiento de linfocitos Th2 [194].

Sin embargo, se han descrito algunos resultados contradictorios respecto a la función de PTGDR en la patología asmática, proponiéndose incluso un papel antiinflamatorio para este receptor. Su activación en la superficie de los basófilos inhibe su migración y su desgranulación dependiente de $\lg E$ [176]. Sobre su función en los eosinófilos los estudios arrojan informaciones opuestas, mientras 
unos presentan hallazgos de un aumento de la supervivencia de estas células, otros encuentran lo contrario, incluso que a través de DP se inhibe su activación [182, 191]. Así mismo se ha descrito la inhibición de la activación y la migración de células dendríticas a los nódulos linfocitarios vía DP [176].

\section{$>$ MODELOS ANiMALES}

La deleción completa del gen PTGDR en ratones con asma inducida por la sensibilización con ovoalbúmina (OVA) provoca la inhibición de la respuesta inflamatoria en las vías respiratorias mediada por este alérgeno. La pérdida del receptor no afecta a la respuesta inmune inicial, los niveles de $\lg E$ frente a la OVA son similares respecto a los ratones control portadores del gen; sin embargo las concentraciones de citocinas Th2 (IL-4, IL-5 e IL-13), así como los linfocitos y eosinófilos disminuyen notablemente en el líquido del LBA tras la exposición al alérgeno y en ausencia de este receptor [179]. En modelos similares de asma alérgica en ratones y cobayas los resultados han apuntado hacia esta función pro-inflamatoria de PTGDR, promotora de la repuesta Th2.

- La exposición a $\mathrm{PGD}_{2}$ previamente al contacto con el alérgeno en ratones con asma inducida por OVA no sólo produce una mayor respuesta Th2 en cuanto a infiltración celular y producción de citocinas en la muestra de LBA, sino que también se registra una mayor expresión de MDC. La aplicación de un anticuerpo específico frente a esta citocina inhibe el efecto del pretratamiento con $\mathrm{PGD}_{2}$, lo cual plantea su papel como intermediario entre PTGDR y la respuesta Th2 [195].

- La sobreexpresión en el pulmón de la sintasa específica de $\mathrm{PGD}_{2}$ LPGDS en ratones asmáticos según el citado modelo, incrementa las concentraciones de IL-4 e IL-5 y la infiltración eosinofílica en el líquido del LBA [179]. 
- La inhalación de S-5751, antagonista selectivo de PTGDR en cobayas con este modelo de asma produce una disminución de la infiltración eosinofílica en el pulmón [198]

- Los ratones deficitarios en uteroglobina, proteína antiinflamatoria que se une a $\mathrm{PGD}_{2}$ impidiendo su unión a PTGDR presentan niveles elevados de esta prostaglandina en la muestra de LBA y mayor expresión de COX2 en células epiteliales, fibroblastos y células musculares a través de la transmisión de señales promovida por DP [176].

Ya en otras especies animales como los perros, la administración de $\mathrm{PGD}_{2}$ en las vías respiratorias induce un marcado reclutamiento de eosinófilos [179] y una reducción transitoria pero importante de los eosinófilos circulantes [166, 182].

\section{ESTVDIOS GENETICOS}

En la búsqueda de genes asociados al asma y la atopia, una de las estrategias seguidas, como se ha comentado previamente, ha sido el estudio de ligamiento por el que diferentes marcadores génicos, en este caso del cromosoma 14, han resultado ligados al asma o fenotipos relacionados [112, 141, 199, 200] . A partir de un estudio de ligamiento con la regulación de los niveles de $\lg E$ en suero, se determinaron dos nuevos marcadores ligados al asma; y por tanto una nueva región cromosómica, la 14q13-23, candidata a albergar genes implicados en la patología asmática. Aunque los autores de este trabajo no pensaron inicialmente en PTGDR, lo cierto es que este gen se encuentra próximo a uno de los marcadores que resultaron asociados, el D14S63 [200]. 
Tras la asociación de este gen con el asma y la alergia a causa de su localización génica [199-201] y de los resultados obtenidos en estudios funcionales en modelos animales [179], se realizaron diferentes trabajos de clonación posicional [202] y de asociación entre la patología asmática y determinados polimorfismos presentes en la región promotora y en la región codificante del gen en distintas poblaciones [203-210]. Sin embargo, existe cierta controversia en los estudios de asociación y, en ocasiones, los resultados no son reproducibles [204], lo cual analizaremos más adelante.

Se han detectado determinadas asociaciones entre los polimorfismos presentes en la región promotora de PTGDR $-613 \mathrm{C}>\mathrm{T},-549 \mathrm{~T}>\mathrm{C},-441 \mathrm{C}>\mathrm{T}$ y 197T>C y el fenotipo asmático [203, 206, 207]. El control de la expresión de un gen se lleva a cabo principalmente a través de elementos reguladores en su región promotora. Dichas variantes se encuentran en sitios de unión de factores transcripcionales, de hecho se ha descrito su capacidad de alterar la unión de estos elementos de control de la transcripción [203]. Determinadas combinaciones haplotípicas y diplotípicas de estas variantes se asocian a una mayor eficacia transcripcional y por tanto una mayor expresión de PTGDR; mientras otras combinaciones se asocian con un efecto protector frente a la patología asmática debido a una menor unión de los factores de transcripción y una disminución de la expresión del receptor.

Los resultados obtenidos hasta el momento sobre la asociación de los polimorfismos de dicha región promotora y las distintas combinaciones haplotípicas y diplotípicas con el fenotipo asmático necesitan más estudios funcionales con los que determinar los mecanismos moleculares que controlan la expresión del gen PTGDR, la cual parece estar ligada a la aparición de la enfermedad asmática. Un estudio completo de estos procesos desde las variantes génicas, interacciones génicas y regulación de la trascripción, permitirá 
conocer cómo intervenir sobre los mismos y poder identificar futuras dianas terapéuticas lo que redundaría en una mejora en la calidad del manejo clínico de dichos pacientes. 


\section{HİP@́TESíS}

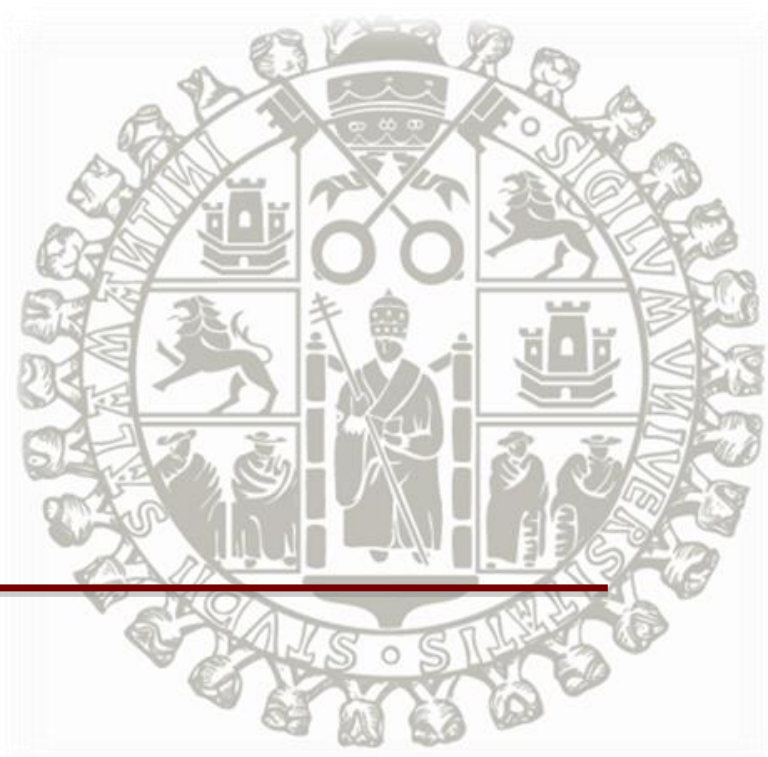





\section{HİPÓTESISS}

Nuestra principal hipótesis de trabajo es que la presencia de ciertos polimorfismos en la región promotora del gen PTGDR podría estar relacionada con las características clínico-biológicas de los pacientes con asma y que la asociación con el asma podría estar determinada por las combinaciones haplotípicas de dichos polimorfismos.

La hipótesis secundaria es que la presencia de polimorfismos en la región promotora del gen PTGDR podría producir cambios en la afinidad de la unión de los factores de regulación transcripcional al promotor de dicho gen, que darían lugar a cambios en los patrones de expresión del gen con posibles consecuencias en el desarrollo del fenotipo asmático. La identificación de dichos mecanismos podría proporcionar información determinante sobre posibles dianas terapéuticas. 



\section{OBJETİVOS}

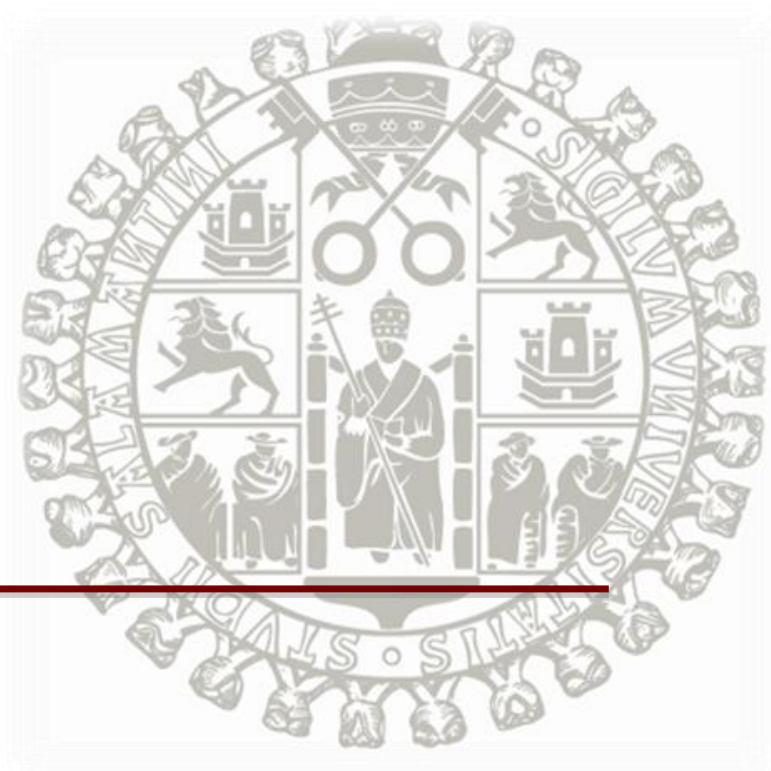





\section{OBJETIVOS}

1. Determinar las frecuencias alélicas y genotípicas de los polimorfismos $-197 \mathrm{~T}>\mathrm{C},-441 \mathrm{C}>\mathrm{T},-549 \mathrm{~T}>\mathrm{C}$ y $-613 \mathrm{C}>\mathrm{T}$ del gen PTGDR en una población de pacientes con asma respecto a una población control estrictamente seleccionada. Valorar la relación de los polimorfismos individualmente considerados con los parámetros clínico-biológicos.

2. Establecer las combinaciones haplotípicas y diplotípicas de los distintos polimorfismos, tanto en el grupo control como en los pacientes.

3. Analizar las posibles asociaciones de los haplotipos y diplotipos con el fenotipo de asma.

4. Analizar los mecanismos moleculares mediante los cuales la presencia de estos polimorfismos podrían determinar los cambios de expresión de este gen mediante procesos de regulación transcripcional.

5. Estudiar los posibles factores de transcripción que se unen a las secuencias reguladoras en el promotor de PTGDR, determinando los cambios de expresión del mismo, incluyendo la posible identificación de dianas terapéuticas. 



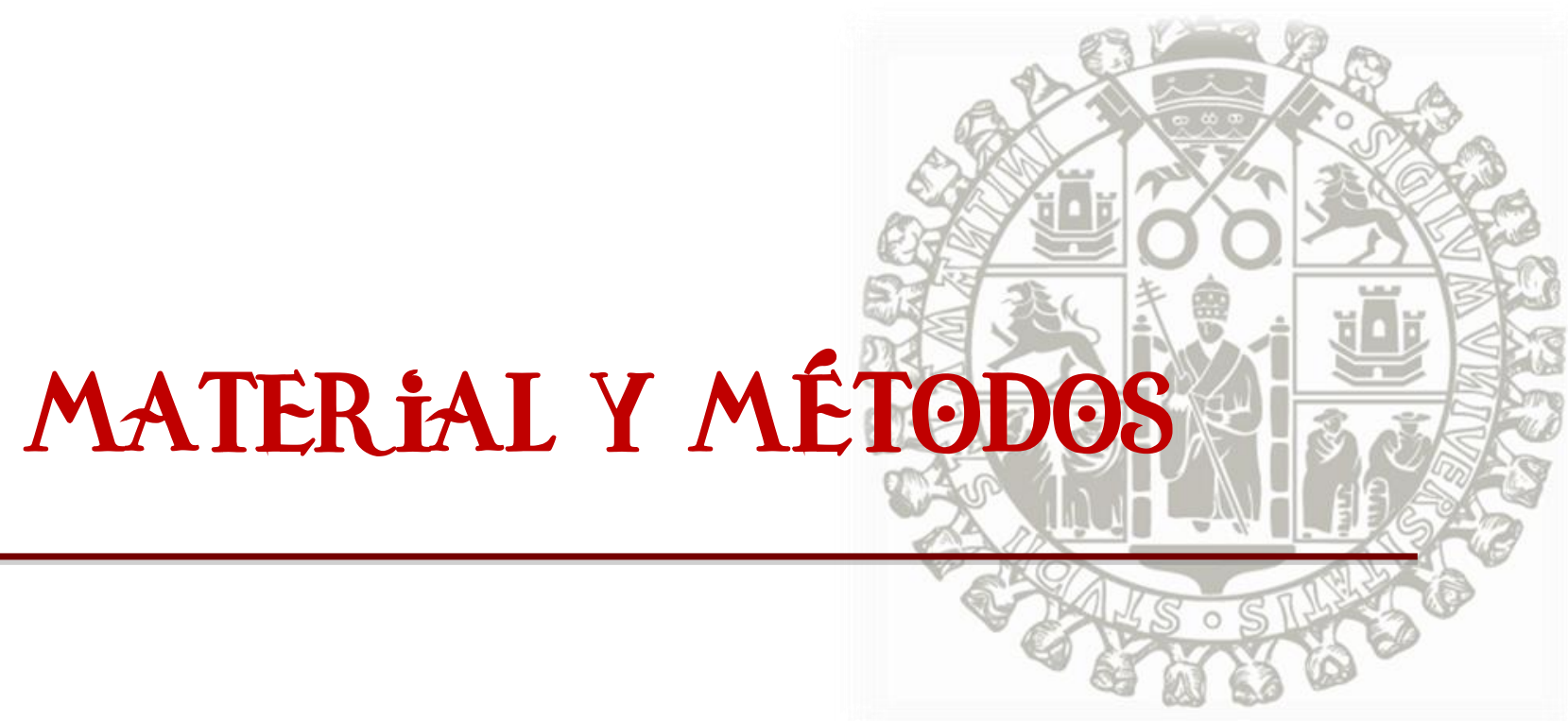





\section{MATERIAL Y MÉTODOS}

\subsection{ESTVDIO DE CASOS Y CONTROLES}

En este estudio han participado un total de 675 individuos que acudieron al Servicio de Inmunoalergia del Complejo Asistencial de Salamanca y aceptaron su inclusión en el mismo a través de un consentimiento informado; siguiendo las normas legales para Estudios Clínicos en España y las del Comité de Ética del Complejo Asistencial Universitario de Salamanca.

Los Facultativos Especialistas en Alergología de dicho servicio examinaron a todos y cada uno de los individuos y recogieron una serie de datos referentes a su situación a través de un formulario (apéndice). Los datos se incluyeron en el estudio como variables y se detallan a continuación. Del mismo modo, se establecieron unos estrictos criterios de selección de los individuos control y de los pacientes, como también se describe más adelante.

\section{DATOS RECOGIDOS}

Se recogieron datos de filiación, como el nombre, apellidos, número de historia clínica, edad, sexo, fecha de nacimiento, así como la fecha de consulta y los datos del facultativo que llevó a cabo la exploración del individuo. Estos datos sólo se emplearon en la identificación inicial de cada individuo, pero no se reflejan en ningún otro momento a lo largo del estudio o el análisis, que se realizó aplicando un sistema de disociación de datos. Los estudios de laboratorio se realizaron desconociendo si la muestra procedía de un paciente o de un 
individuo del grupo control. Entre las variables clínicas consideradas se incluyen la presencia de asma, el tipo y el grado, la presencia de atopia, la intolerancia a antiinflamatorios no esteroideos (AINE), la existencia de poliposis y los valores de $\lg E$, entre otros.

\section{PACIENTES}

Se incluyeron en el estudio un total de 425 pacientes adultos, 371 diagnosticados de asma por los Facultativos Especialistas del Servicio de Inmunoalergia del Complejo Asistencial Universitario de Salamanca y un pequeño grupo de 54 pacientes con pruebas cutáneas positivas que no presentaban asma como control estadístico de la asociación. Los criterios consensuados de interpretación de los datos clínicos y analíticos, que a su vez fueron recogidos en forma de variables para el estudio, se describen a continuación.

\section{DIAGNOSTICO DE ASMA}

Los criterios para el diagnóstico de asma fueron:

- Al menos dos síntomas consistentes con asma (tos, disnea, sibilancias, opresión torácica).

- Ausencia de otras enfermedades pulmonares.

- Alteraciones en la función pulmonar: Según las normas de la ATS (American Thoracic Society) [211] se realizó un espirometría basal. A todos los pacientes con $\mathrm{FEV}_{1} / \mathrm{FVC}<0,7$ se les realizó una prueba de broncodilatación; si ésta fue negativa, se continuó con una prueba de hiperreactividad bronquial con metacolina [212]. La prueba broncodilatadora se consideró positiva cuando se observó una mejoría 
del $\mathrm{FEV}_{1}>12 \%$ y más de $200 \mathrm{ml}$. Se consideró positiva una $\mathrm{PC}_{20}$ metacolina $<16 \mathrm{mg} / \mathrm{ml}$.

\section{GRAVEDAD DE ASMA}

La gravedad de asma se determinó, cuando fue posible, en condiciones basales, es decir sin tratamiento, y se clasificó en una de las cuatro categorías establecidas por la GINA (Global Initiative for Asthma) [3].

\section{ASMA INTERMÍTENTE}

- Aparición de síntomas con una frecuencia menor de una vez por semana.

- Crisis de corta duración.

- Síntomas nocturnos con una frecuencia menor de dos veces al mes.

- $\mathrm{FEV}_{1}$ O PEF $\geq 80 \%$.

- Variabilidad del PEF o FEV $1<20 \%$.

\section{ASMA LEVE PERSİSTENTE}

- Aparición de síntomas más de una vez a la semana pero no diariamente.

- Episodios nocturnos más de dos veces al mes.

- $\mathrm{FEV}_{1}$ o PEF $\geq 80 \%$.

- Variabilidad del PEF o FEV $1<20 \%-30 \%$.

\section{ASMA MODERADA PERSíSTENTE}

- Síntomas diarios.

- Las crisis pueden afectar la actividad diaria y el sueño.

- Uso diario de $\beta-2$ agonistas inhalados.

- $\mathrm{FEV}_{1}$ o PEF $60-80 \%$. 
- Variabilidad del PEF o $\mathrm{FEV}_{1}>30 \%$.

\section{ASMA PERSISTENTE GRAVE}

- Síntomas diarios.

- Crisis frecuentes.

- Episodios asmáticos nocturnos frecuentes.

- Limitación en las actividades físicas.

- $\mathrm{FEV}_{1}$ o $\mathrm{PEF}<60 \%$

- Variabilidad del FEV 1 o PEF $>30 \%$

En aquellos pacientes en tratamiento para el asma se utilizó una clasificación adaptada de acuerdo al mismo y siguiendo igualmente las recomendaciones de la GINA.

\section{PRESENCIA DE ALERGIA}

En todos los pacientes se realizaron pruebas cutáneas y la determinación de $\lg \mathrm{E}$ total en suero de los pacientes.

\section{$>$ PRVEBAS CVTÁNEAS}

Las pruebas intraepidérmicas (prick) se realizaron siguiendo las recomendaciones para la normalización de alérgenos y pruebas cutáneas de la EAACI (The European Academy of Allergy and Clinical Immunology) [213] con una batería estandarizada de los aeroalérgenos más frecuentes en nuestro entorno, ácaros, pólenes, hongos y epitelios (apéndice). Se empleó una solución de histamina $10 \mathrm{mg} / \mathrm{ml}$ como control positivo y una solución salina como control negativo. Antes de realizar la prueba, se retiraron los antihistamínicos y otros fármacos capaces de interferir con el resultado que el paciente pudiera estar 
tomando, según las indicaciones de la EAACl. La punción en la epidermis se realizó mediante una lanceta de tipo Morrow-Brown, con una punta estandarizada de $1 \mathrm{~mm}$ (figura 29).

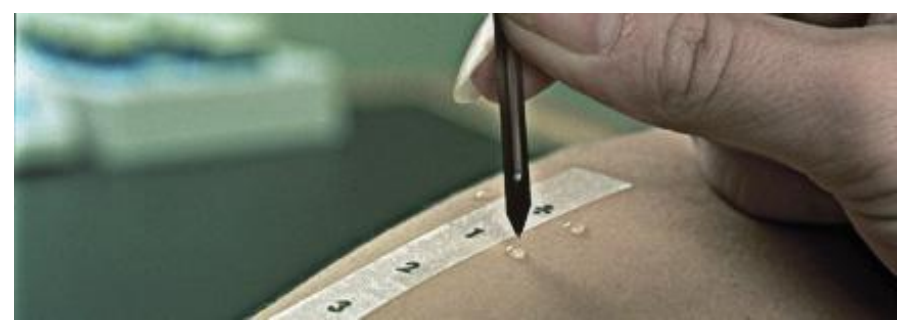

Figura 29. Representación del procedimiento de inyección de los extractos antigénicos y los controles (ALK-Abelló, Madrid, España).

Se consideró positiva una reacción frente al antígeno si se producía una pápula igual o superior a $3 \mathrm{~mm}$ de diámetro respecto de esta misma medida en el control negativo, en caso de producirse pápula en él. Se consideró que el paciente era atópico si presentaba al menos una prueba positiva frente a un alérgeno de las pruebas cutáneas. Mientras que se consideró que el paciente presentaba alergia frente a un determinado alérgeno si además de una prueba positiva existían manifestaciones clínicas concordantes en dicho paciente.

\section{$>$ DETER MINNACIÓN DE IGE}

A todos los individuos se les realizó una extracción de suero, con el fin de determinar los niveles de $\lg \mathrm{E}$ en esta muestra mediante la prueba ImmunoCAP Total IgE y siguiendo las recomendaciones del fabricante (Phadia InmunoCAP 250, Uppsala, Suecia).

Dicha prueba consiste en un enzimoinmunoanálisis en el cual los anticuerpos anti-lgE unidos covalentemente a los pocillos del ImmunoCAP, 
reaccionan con la IgE total del suero del paciente. Tras añadir anticuerpos antiIgE ( $\beta$-galactosidasa-anti-lgE, anticuerpos monoclonales de ratón, $2 \mu \mathrm{g} / \mathrm{ml}$ ) marcados enzimáticamente se forma un inmunocomplejo tipo sándwich. El exceso de anticuerpo unido a la enzima se elimina en una serie de lavados anteriores a la incubación con la solución que contiene el sustrato de dicha enzima. Trascurrido el tiempo establecido para la reacción, ésta se detiene y posteriormente se mide la fluorescencia del producto originado en la misma (figura 30). Utilizando una curva patrón se interpolan las unidades de respuesta y se obtienen las concentraciones de lgE de las muestras de suero.

En los pacientes en los que hubo dudas con el resultado de las pruebas cutáneas se realizó una determinación de lgE específica (Phadia InmunoCAP 250, Uppsala, Suecia).
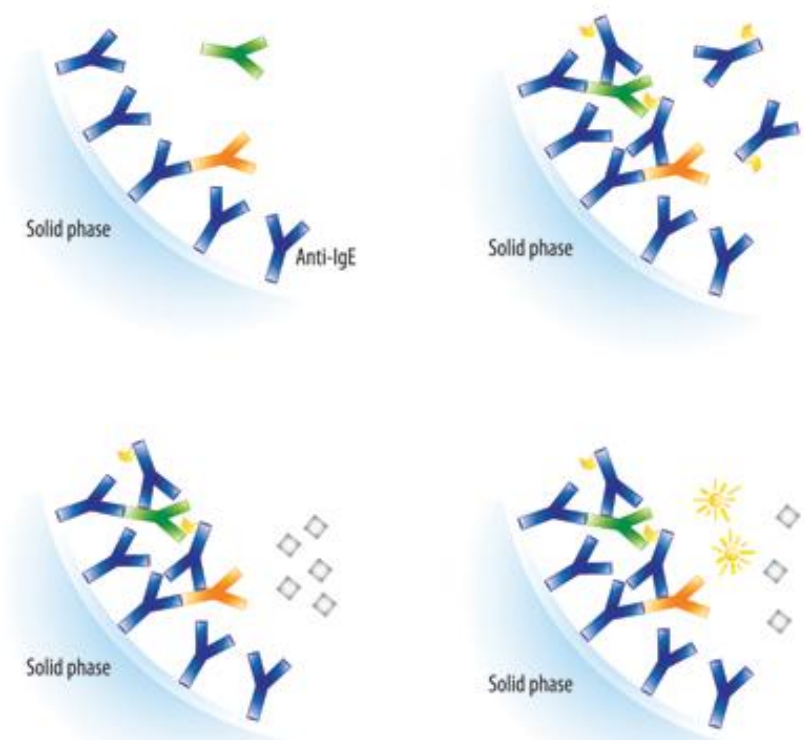

Figura 30. Enzimoinmunoanálisis para la determinación de IgE total. Se representan los pasos del ensayo ordenados de arriba abajo y de izquierda a derecha. En azul los anticuerpos anti-lgE unidos covalentemente a los pocillos, en naranja y verde se muestra la lgE total del suero del paciente a determinar y en azul con amarillo los anticuerpos anti-IgE marcados enzimáticamente (Phadia InmunoCAP 250, Uppsala, Suecia). 


\section{CONTROLES}

El grupo control estuvo constituido por un total de 250 individuos que acudieron al Servicio de Inmunoalergia del Complejo Asistencial de Salamanca y cumplían los siguientes criterios:

- Edad superior a 18 años.

- Ausencia de síntomas y antecedentes de asma.

- Ausencia de síntomas y antecedentes de otras enfermedades respiratorias.

- Ausencia de síntomas y antecedentes de alergia.

- Pruebas cutáneas negativas a la misma batería de aeroalérgenos que a los pacientes.

- Ausencia de antecedentes de asma en familiares de primer grado.

- Ausencia de antecedentes de atopia en familiares de primer grado.

\subsection{ANÁLíSíS MOLECVLAR}

\section{EXTRACCí́N DEL ADN}

A todos los individuos se les realizó una extracción de una muestra de sangre periférica, recogida en un tubo de vacío con EDTA como anticoagulante y almacenada a $-20^{\circ} \mathrm{C}$ hasta el momento de la extracción del ADN.

Se han seguido dos protocolos diferentes de extracción del ADN a partir de sangre total: uno de ellos utilizando el kit comercial DNAPURE "SSS" (Genedan S.L, España.); y otro utilizando el sistema automático MagnaPure Compact Nucleic Acid Isolation Kit I- Large Volume (Roche Applied Science, Mannheim, 
Alemania). La concentración y pureza del ADN obtenido se determinaron después de su extracción.

En este estudio se comenzó extrayendo las muestras con el kit DNAPURE "SSS". La posterior adquisición del sistema MagNAPure permitió obtener un mayor rendimiento con una concentración de ADN más homogénea y de mejor calidad.

\section{KITT DNAPVRE "SSS"}

El primer paso de un protocolo de extracción de ADN a partir de sangre total es la eliminación de los hematíes por ser células anucleadas. En el kit DNAPURE "SSS", la separación de estas células del resto de las células nucleadas se llevó a cabo lisando los hematíes selectivamente mediante una solución contenida en el kit (Solución de lisis RBC). Se incubó $1 \mathrm{~mL}$ de sangre con dicha solución en una proporción de 1:3 durante 10 minutos a temperatura ambiente, invirtiendo el tubo varias veces durante la incubación. Tras este tiempo las muestras se centrifugaron a 3.000 revoluciones por minuto (r.p.m.) y se eliminó el sobrenadante con una pipeta de tipo pasteur.

En el siguiente paso, se añadió la Solución de lisis compuesta por un detergente aniónico en la cual se resuspendió el botón celular mediante un agitador tipo vortex. De esta manera se consiguieron lisar las membranas de las células nucleadas contenidas en él, principalmente leucocitos; en el tercer paso se realizó la precipitación salina de las proteínas celulares y nucleares mediante la adicción de $600 \mu \mathrm{L}$ de solución de precipitación proteica y agitación en vortex seguida de centrifugación a 3.000 r.p.m. durante 5 minutos. El precipitado obtenido contenía estos restos proteicos mientras que el sobrenadante contenía el ADN. Dicho sobrenadante fue transferido a un tubo limpio con $1 \mathrm{~mL}$ de 
isopropanol con el fin de precipitar el ADN mediante agitación y centrifugación de 3 minutos a 3.000 r.p.m. El sobrenadante se desechó y el precipitado de color blanquecino obtenido que contenía el ADN se dejó secar durante 10 minutos.

Por último se lavó el ADN con $1 \mathrm{~mL}$ de etanol al 70\%, se centrifugó durante 10 minutos a 3.000 r.p.m. y se dejó secar otros 15 minutos. Finalmente, se añadieron $200 \mu \mathrm{L}$ de agua destilada con el fin de hidratar el ADN y se conservó a $-20^{\circ} \mathrm{C}$. Mediante la incubación de las muestras a $65^{\circ} \mathrm{C}$ en agitación se resuspendió el ADN y las muestras quedaron listas para su uso.

\section{SISTEMA MAGNAPVRE COMPACT NVCLEİC ACID ISOLATÍON KÍT II}

\section{LARGE VOLVME}

El MagnaPure Compact (Roche Applied Science, Mannheim, Alemania) es un robot automatizado que permite la extracción de ácidos nucleicos a partir de sangre total y de una amplia variedad de otros tipos muestras. Mediante este sistema se obtiene ADN genómico de gran calidad, adecuado para su uso en reacciones de PCR. En este estudio se ha empleado el MagNA Pure Compact Nucleic Acid Isolation Kit I - Large Volume, que permite extraer ADN genómico a partir de sangre total, plasma y células en cultivo siguiendo las indicaciones del fabricante (Roche Applied Science, Mannheim, Alemania).

Se trata de un sistema de partículas magnéticas contenidas en un cartucho que cuenta con una serie de pocillos en los que se encuentran los reactivos necesarios para la extracción. Se precisa un rack de puntas de pipeta estériles con filtro, cuya función es aspirar la muestra y pasarla por los distintos pocillos que contienen dichos reactivos.

Las alícuotas de algo más de $1 \mathrm{~mL}$ de sangre, almacenadas a $-20^{\circ} \mathrm{C}$, se descongelaron a temperatura ambiente. Se encendió el instrumento y se 
seleccionó el protocolo DNA blood_1000, con el cual se trabaja con un volumen inicial de sangre total de $1 \mathrm{~mL}$ y un volumen de elución final de $200 \mu \mathrm{L}$. Se introdujeron en el carrusel los cartuchos de reactivos tras la lectura de su código de barras y se colocaron las puntas desechables en equipo.

Se identificaron debidamente los criotubos a los que se añadió $1 \mathrm{~mL}$ de la muestra de sangre correspondiente y se colocaron en la parte posterior del rack de muestras. Dicha identificación se introducía también en el ordenador del instrumento. Los tubos de elución se colocaron en la parte delantera del rack de muestras correctamente identificados, no sólo a través del número de laboratorio de la muestra, sino también mediante la lectura de su código de barras en el ordenador del instrumento. Una vez identificados todos los componentes, se introdujeron en el aparato y se inició la extracción automática, que dura unos treinta y cinco minutos aproximadamente.

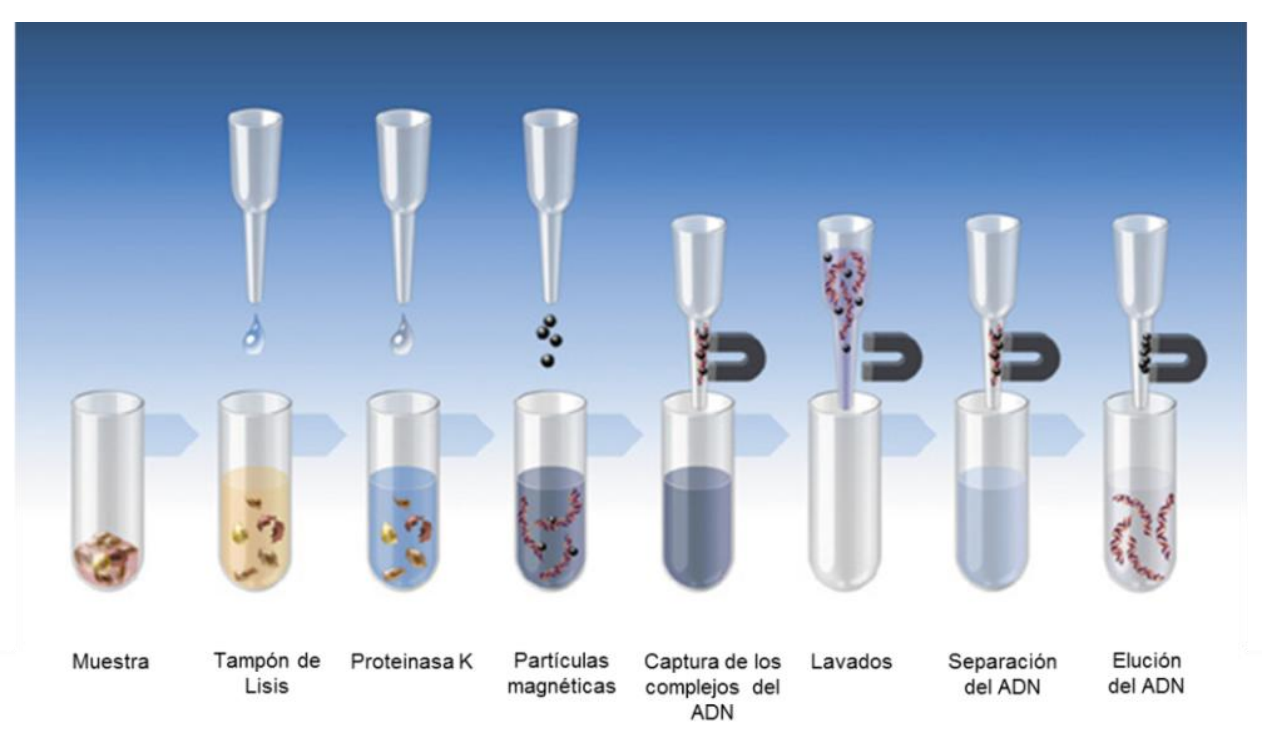

Figura 31. Secuencia de los pasos del procedimiento de extracción del MagnaPure Compact. 
El protocolo emplea un tampón de lisis que contiene proteinasa $\mathrm{K}$ para destruir proteínas, Tritón X-100; detergente que facilita la disrupción de las membranas celulares e inhibidores de desoxirribonucleasas y ribonucleasas. Dicha solución se incuba con la muestra de sangre total y, tras una incubación posterior a temperatura elevada, se añade una solución con partículas magnéticas e isopropanol, con el fin de aislar las moléculas de ácidos nucleicos en estas partículas. Tras una serie de lavados se procede a la separación del ADN de la partícula magnética por calor y elución con Tris-EDTA en el tubo de elución (figura 31).

Una vez extraídas las muestras se evaluó el rendimiento de las mismas mediante la determinación de la absorbancia a $260 \mathrm{~nm}$ y $280 \mathrm{~nm}$ en el espectrofotómetro BioPhotometer (Eppendorf AG, Hamburgo, Alemania) con el fin de analizar la cantidad y calidad de ADN extraído. Para ello se determinó la absorbancia de las muestras diluidas al 1/50 con agua destilada en un volumen final de $100 \mu \mathrm{L}$. Las mediciones de la absorbancia a $260 \mathrm{~nm}$ y el ratio $260 / 280$ se realizaron por triplicado, con el fin de calcular los valores promedio de las mismas. En cuanto a la calidad del ADN se consideraron válidos cocientes $260 / 280$ entre 1,8 y 2.

\section{ANÁLISSIS DE GENOTíPOS Y HAPLOTİPOS}

Se ha analizado un fragmento de 642 pares de bases (pb) de la región promotora de PTGDR en un total de 675 individuos, con el fin de determinar 4 polimorfismos ya descritos en la bibliografía dentro de esta región -613 C>T $(r s 34236606), \quad-549 \mathrm{~T}>\mathrm{C} \quad(\mathrm{rs} 8004654), \quad-441 \mathrm{C}>\mathrm{T} \quad(\mathrm{rs} 803010) \quad$ y $\quad-197 \mathrm{~T}>\mathrm{C}$ (rs11157907) (figura 32). 


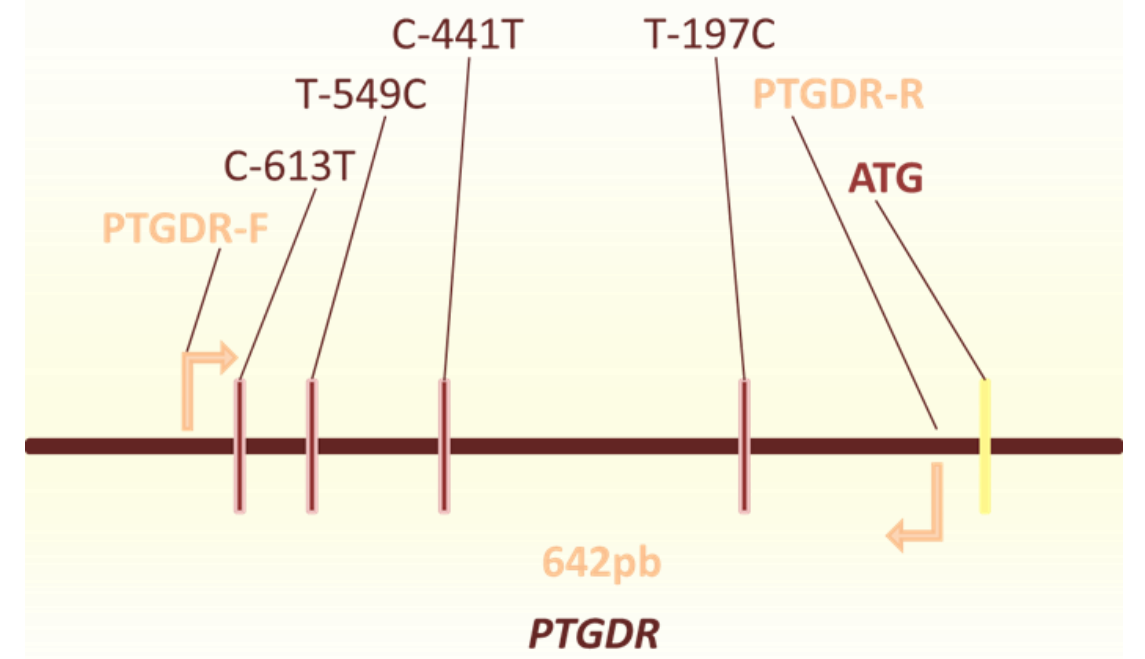

Figura 32. Esquema de la región promotora de PTGDR. Se representan los polimorfismos, el punto de inicio de la transcripción y la localización de los cebadores para la amplificación de esta región.

\section{AMPLiFíCACí́N}

Las muestras de ADN obtenidas a partir de sangre periférica siguiendo los protocolos de extracción fueron amplificadas en la región correspondiente al promotor del gen PTGDR mediante PCR (reacción en cadena de la polimerasa) con cebadores que flanquean dicha región específicamente (figura 32).

La amplificación se llevó a cabo en un volumen final de $25 \mu \mathrm{L}$. En cada reacción se añadieron 12,5 $\mu \mathrm{L}$ de PCR-Master Mix (Promega, Madison, WI, EEUU) (22 mM Tris-HCl (pH 8.4), $55 \mathrm{mM} \mathrm{KCl,} 1.65 \mathrm{mM} \mathrm{MgCl}, 220 \mu \mathrm{M}$ dNTP, 22U Taq DNA polimerasa), 7,5 $\mu \mathrm{L}$ de agua libre de nucleasas, $20 \mathrm{ng}$ de ADN genómico y 1,25 pmol de cada oligonucleótido cebador (sentido y antisentido). Como control negativo en cada serie se empleó un tubo con todos los componentes de la reacción menos el ADN. Las reacciones de amplificación se llevaron a cabo en un termociclador de MWG-BIOTECH (Biothech, Ebersberg, Alemania). 
Los oligonucleótidos utilizados en la reacción de PCR, se presentan en el apéndice siendo PTDGR-F el cebador forward (sentido) complementario de la hebra $3^{\prime} \rightarrow 5^{\prime}$ de ADN y PTDGR-R el cebador reverse (antisentido); complementario de la hebra $5^{\prime} \rightarrow 3^{\prime}$. Todos ellos fueron diseñados a partir de la secuencia del promotor del gen de PTGDR depositada en la base de datos GenBank (http://www2.ncbi.nlm.nih.gov/cgi-bin/genbank) y se suministraron como un liofilizado. Posteriormente fueron reconstituidos con agua destilada libre de nucleasas (Promega, Madison, WI, EEUU) y almacenados en alícuotas a $-20^{\circ} \mathrm{C}$.

\section{PROGRAMA DE AMPLIFiCACiÓN}

El programa de PCR resultante de determinados ensayos en la puesta a punto del mismo fue el empleado para la amplificación de la región de interés y se detalla a continuación (figura 33).

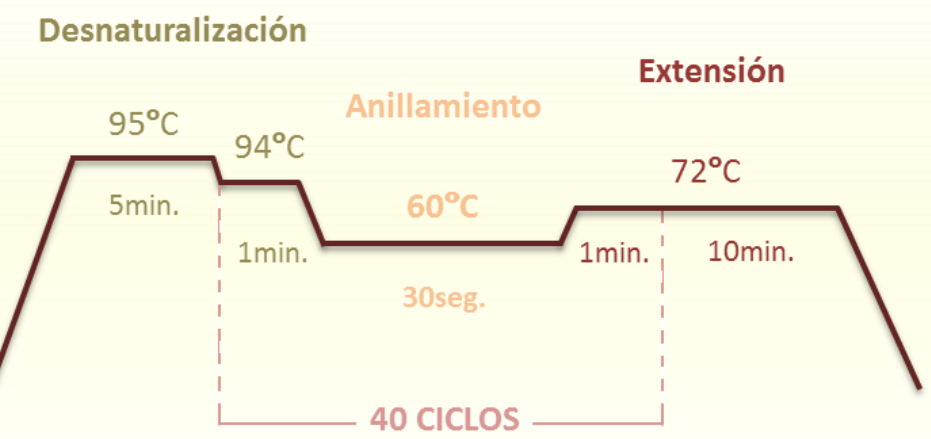

Figura 33. Programa de PCR empleado para la amplificación del promotor de PTGDR. 


\section{ELECTROFORESIS EN GEL DE AGAROSA}

Los productos de PCR fueron separados por su tamaño molecular mediante electroforesis en geles horizontales de agarosa de alta resolución al $2 \%$ y tampón TAE al 0,5X. Para su preparación se utilizó agarosa NuSieve® 3:1 Agarose (Cambrex Bio Science Rockland, Inc, EEUU) y tampón TAE Buffer al 10X (Promega, Madison, WI, EEUU), compuesto por $400 \mathrm{mM}$ de Tris-acetato y 10 mM de EDTA a pH 8,2-8,4; que se diluyó al 0,5X con agua destilada.

La agarosa se disolvió en el TAE 0,5X calentando la mezcla en un horno microondas. Posteriormente se dejó enfriar hasta $50-60^{\circ} \mathrm{C}$, se añadieron $5 \mu \mathrm{L}$ de bromuro de etidio al $2 \%$ por cada $100 \mathrm{~mL}$ de gel y se depositó en la cubeta de electroforesis, colocando a continuación el peine de pocillos. El bromuro de etidio actúa intercalándose entre las bases nitrogenadas del ADN y emite fluorescencia al ser iluminado con luz ultravioleta (254 nm), de manera que a través de este compuesto se visualizan el o los fragmentos de ADN presentes en la muestra, incluyendo el exceso de los cebadores de la PCR en caso de haberlos. Transcurridos aproximadamente 40 minutos, dependiendo de las condiciones ambientales del laboratorio, se solidificó el gel y la cubeta se sumergió en TAE $0,5 X$

Se procedió a cargar un volumen de $5 \mu \mathrm{L}$ de cada uno de los productos de PCR previamente mezclados con $1 \mu \mathrm{L}$ de tampón de carga DNA Loading Buffer Red (Bioline) que migra en un gel de agarosa al $2 \%$ con los fragmentos de $300 \mathrm{pb}$, con el fin de monitorizar la migración del ADN (figura 34). En todos los geles se cargó un marcador de peso molecular, concretamente el DNA Molecular Weight Marker VIII (Roche Applied Science, Mannheim, Alemania), cuyo patrón se muestra en la figura 34. Esto permitió contrastar en paralelo el tamaño del producto de PCR obtenido y estimar su calidad. 

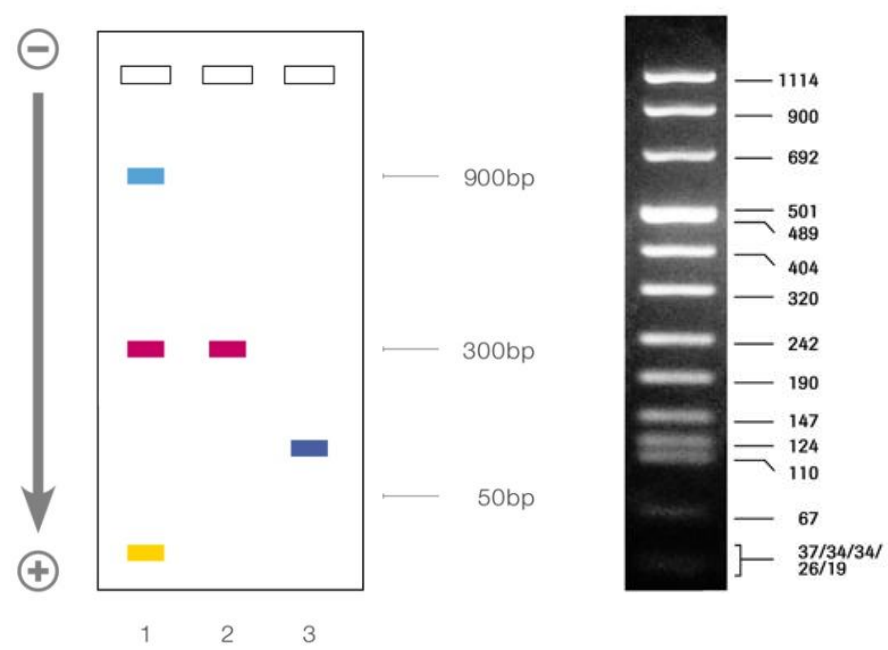

Figura 34. Tampones de carga DNA Loading Buffer (izquierda) y patrón de bandas del Marker VII (derecha) en geles de agarosa al 2\%. En el pocillo no 2 del primer gel se representa la banda del tampón de carga DNA Loading Buffer Red (Bioline) empleado en este trabajo.

Tras aplicar al gel una corriente eléctrica de 120 Voltios durante 30 minutos, éste fue analizado en un transiluminador de luz ultravioleta con el sistema fotográfico VisiDoc-It ${ }^{\mathrm{TM}}$ Imaging System (Uplant, CA, EEUU). En las imágenes se identificaron las muestras y quedaron almacenadas según la fecha del experimento concordante con este dato en el cuaderno de trabajo (figura 35).

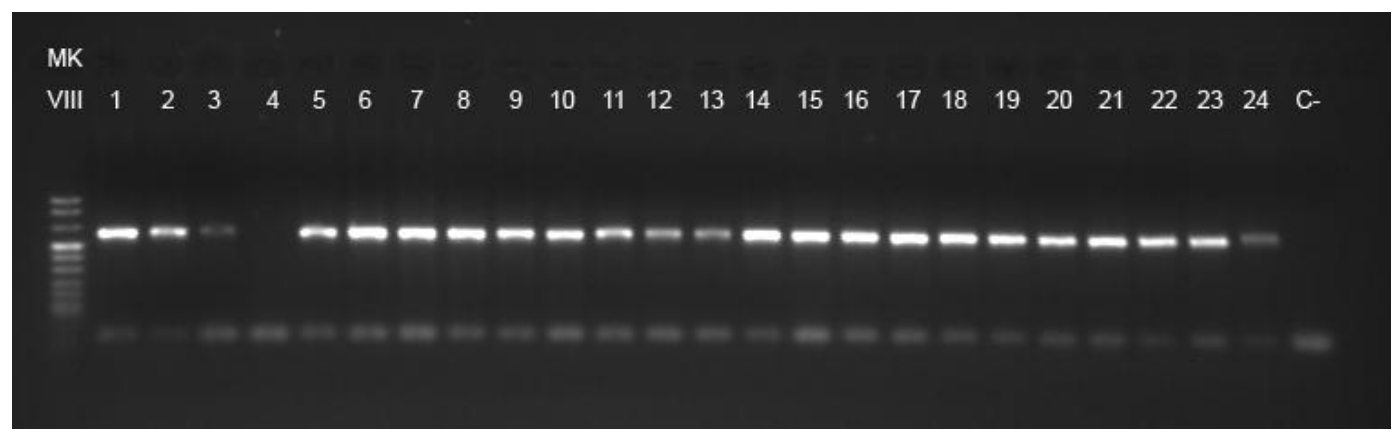

Figura 35. Electroforesis de los fragmentos amplificados por PCR del promotor de PTGDR. Se visualizan las bandas correspondientes al amplicón de $642 \mathrm{pb}$ entre los fragmentos del patrón de bandas (MK VIII) de 692 y 509 pb, menos en la muestra 4 en la cual no hay amplificación y en el pocillo del control negativo (C-). En todas ellas, incluido el C- se observa el exceso de cebadores de un tamaño de 20 pb. 


\section{PVRÍFíCACIÓN DE LOS FRAGMENTOS AMPLIFICADAOS}

La purificación de los amplicones se llevó a cabo inicialmente mediante el kit comercial GENECLEAN ${ }^{\circledR}$ Turbo (Qbiogene, Inc., Carlsbad CA, EEUU), que permite eliminar fragmentos de $\mathrm{ADN}$ de un tamaño entre 0,1 Kilobases $(\mathrm{Kb})$ y $300 \mathrm{~Kb}$, y en la parte final de este trabajo se empleó el kit ExoSAP-IT (USB, Cleveland, Ohio, EEUU) con el que se purifican productos de PCR de 100 pb hasta $20 \mathrm{~Kb}$. Con ambos métodos se separaron los fragmentos de ADN de interés del exceso de oligonucleótidos procedente de la reacción de PCR.

\section{$>$ SISTEMA GENECLEAN TVRBO}

El procedimiento se basa en una extracción en fase sólida, basado en la propiedad del ADN de unirse a una matriz de sílice cuando se encuentra en un medio con una elevada concentración de sales, y por el contrario, de liberarse de dicha unión a bajas concentraciones salinas (figura 36).

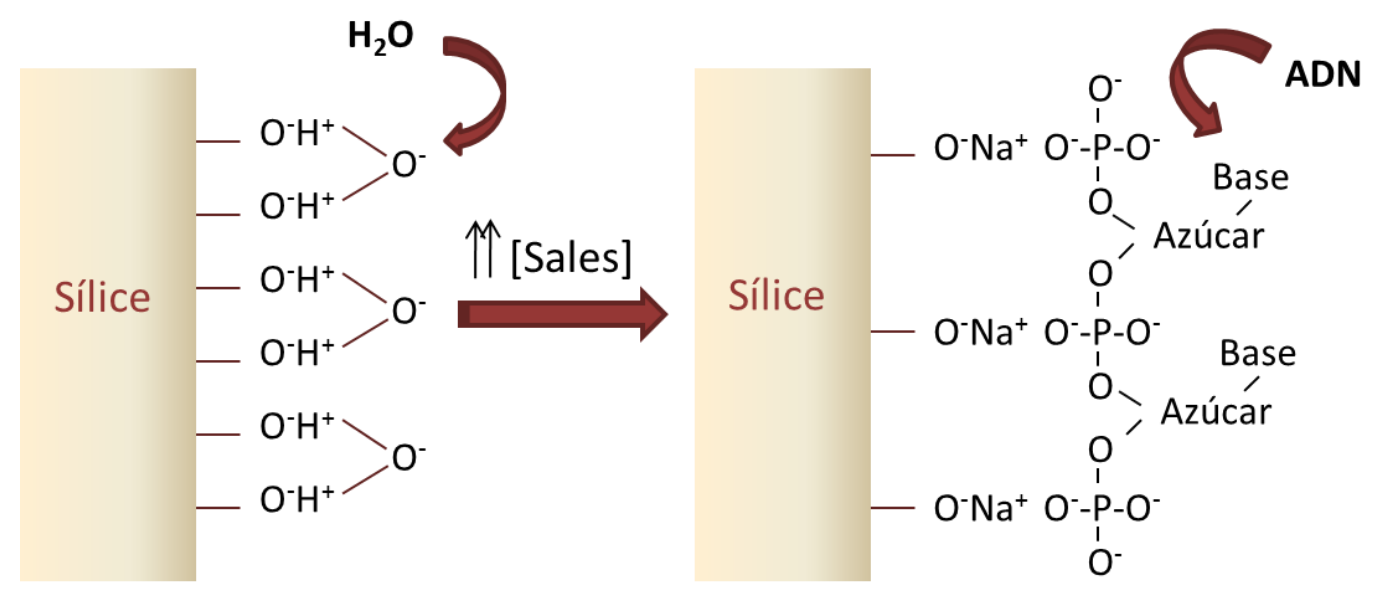

Figura 36. Principio de purificación del kit GENECLEAN ${ }^{\circledR}$ Turbo. 
El protocolo que se siguió fue el indicado por el fabricante a partir de los $20 \mu \mathrm{L}$ producto de la reacción de PCR, tras retirar el volumen empleado en la electroforesis. Los reactivos aportados por el kit son las soluciones de preparación de la muestra (GENECLEAN ${ }^{\circledR}$ Turbo Salt Solution), elución (GENECLEAN ${ }^{\circledR}$ Turbo Elution Solution) y lavado (GENECLEAN ${ }^{\circledR}$ Turbo Wash); la solución fue reconstituida con la cantidad de etanol puro indicada por el fabricante. Los materiales proporcionados son la matriz de sílice (GENECLEAN ${ }^{\circledR}$ Turbo Cartridge) y los tubos de recolección, tanto de desechos como de muestra purificada (GENECLEAN ${ }^{\circledR}$ Turbo Catch Tube).

El primer paso consistió en añadir 5 volúmenes de GENECLEAN $^{\circledR}$ Turbo Salt Solution al volumen de PCR para conseguir las condiciones en las que el ADN quedara retenido en la matriz del GENECLEAN ${ }^{\circledR}$ Turbo Cartridge colocado en un GENECLEAN $^{\circledR}$ Turbo Catch Tube.

Tras una breve centrifugación, se descartó el sobrenadante y se llevó a cabo un paso de lavado del ADN con $500 \mu \mathrm{L}$ del buffer GENECLEAN ${ }^{\circledR}$ Turbo Wash. El sobrenadante se descartó en dos pasos consecutivos de centrifugación con el fin de asegurar que la matriz quedara libre de esta solución de lavado. En el último paso se añadieron sobre el GENECLEAN ${ }^{\circledR}$ Turbo Cartridge colocado a su vez sobre un nuevo GENECLEAN ${ }^{\circledR}$ Turbo Catch Tube, $30 \mu$ de GENECLEAN ${ }^{\circledR}$ Turbo Elution Solution para romper las interacciones del ADN con la matriz de sílice y recoger el ADN purificado en esta disolución.

Este paso de purificación se comprobó mediante electroforesis en geles horizontales de agarosa de alta resolución al 2\% y tampón TAE al 0,5X. 


\section{EXOSAP - IT}

El kit ExoSAP-IT es un sistema de purificación de ADN innovador y rápido. Contiene, en un tampón especial, dos enzimas con actividades hidrolíticas completarías; la Exonucleasa I y la Fosfatasa Alcalina de camarón (Pandauls borealis) que actúan en la mezcla de PCR procesando los fragmentos de ADN de cadena sencilla de pequeño tamaño como los oligonucleótidos y los desoxiribonucleótidos trifosfato (dNTP) sobrantes en la reacción hasta nucleósidos y fosfato libre (figura 37). Posteriormente las enzimas se inactivan mediante calor $\left(80^{\circ} \mathrm{C}\right)$, quedando el fragmento de interés libre de interferencias para la secuenciación.

Mezcla de PCR Post-Amplificación

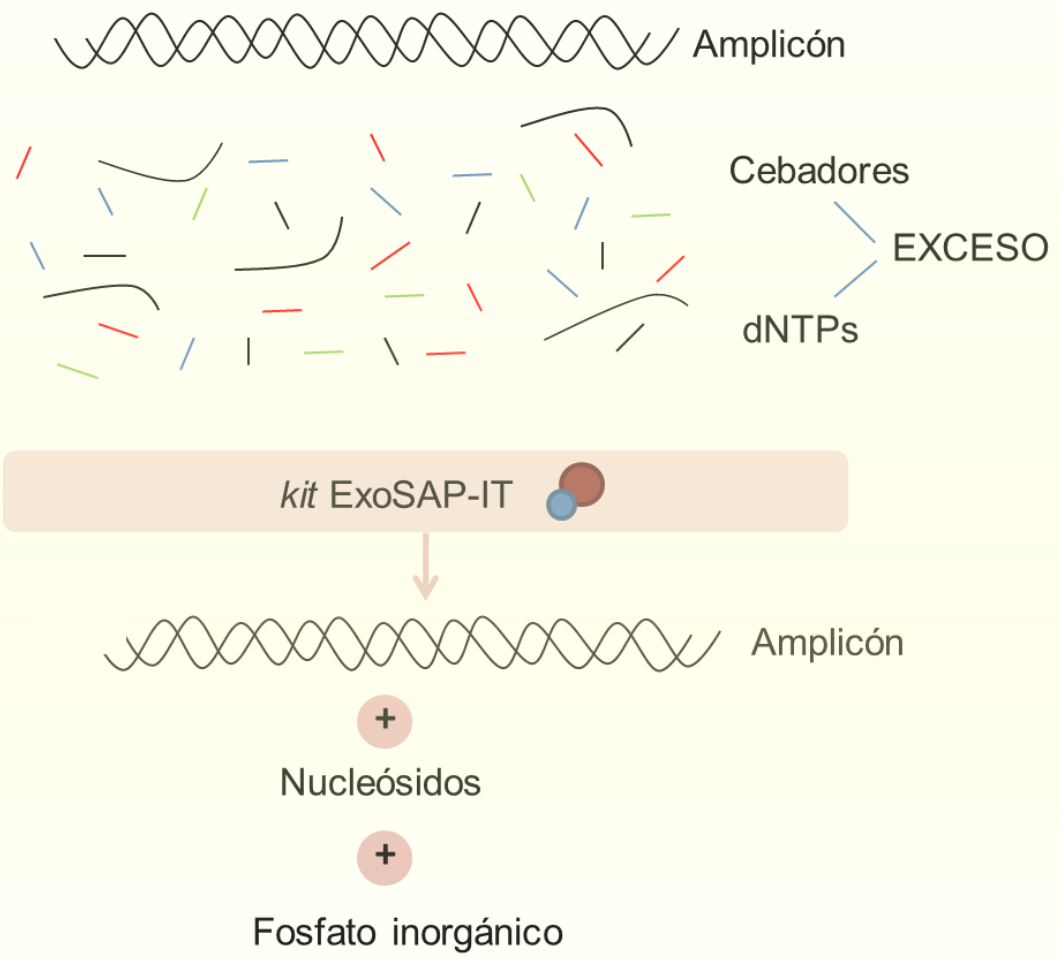

Figura 37. Principio de purificación del kit ExoSAP-IT. 
La purificación se llevó a cabo en un volumen final de $5 \mu \mathrm{L}$. En cada reacción se añadió $1 \mu \mathrm{L}$ de ExoSAP-IT (USB, Cleveland, Ohio, USA) y $4 \mu \mathrm{L}$ de la reacción de PCR obtenida. Las reacciones de hidrólisis e inactivación se llevaron a cabo en un termociclador de MWG-BIOTECH (Biothech, Ebersberg, Alemania) (figura 38).

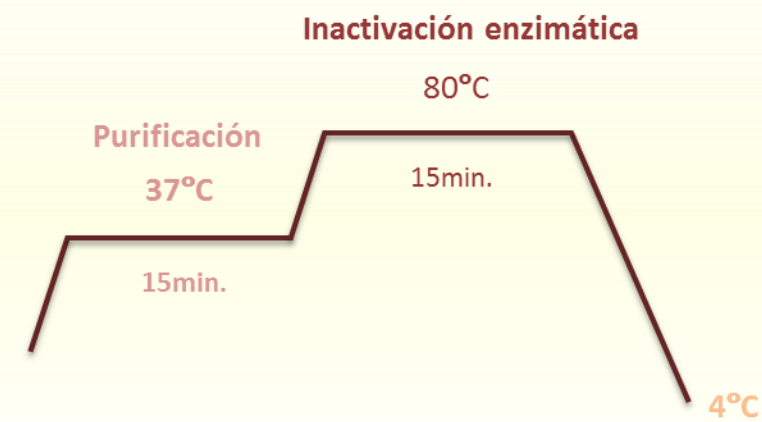

Figura 38. Programa de purificación de ExoSAP-IT.

\section{SECVENCIACIÓN AVTOMÁTICA DEL ADN}

La secuenciación automática de los fragmentos de ADN amplificados por PCR a partir del ADN genómico, se llevó a cabo en un secuenciador automático ABI PRISM 377 DNA Sequencer (Life technologies, NY, EEUU) usando el cebador específico correspondiente, así como terminadores marcados con cromóforos fluorescentes y la enzima Taq polimerasa (Perkin Elmer, Massachusetts, EEUU), según las instrucciones recomendadas por el fabricante.

Las muestras para secuenciación se prepararon en un volumen final de $8 \mu \mathrm{L}$, añadiendo $3 \mu \mathrm{L}$ de cebador antisentido (PTGDR-R) a una concentración de $1 \mu \mathrm{M}$ a $5 \mu \mathrm{L}$ de muestra de PCR purificada. 
El análisis de las secuencias obtenidas se ha llevado a cabo a través de diferentes programas informáticos. La lectura y tratamiento de las secuencias automáticas se realizó en el ChromasPro 1.32 (Technelysium Ptv. Ltd, Tewantin, Australia) y Chromas 2.3 (Technelysium Pty.Ltd, Tewantin, Australia) (figura 39).
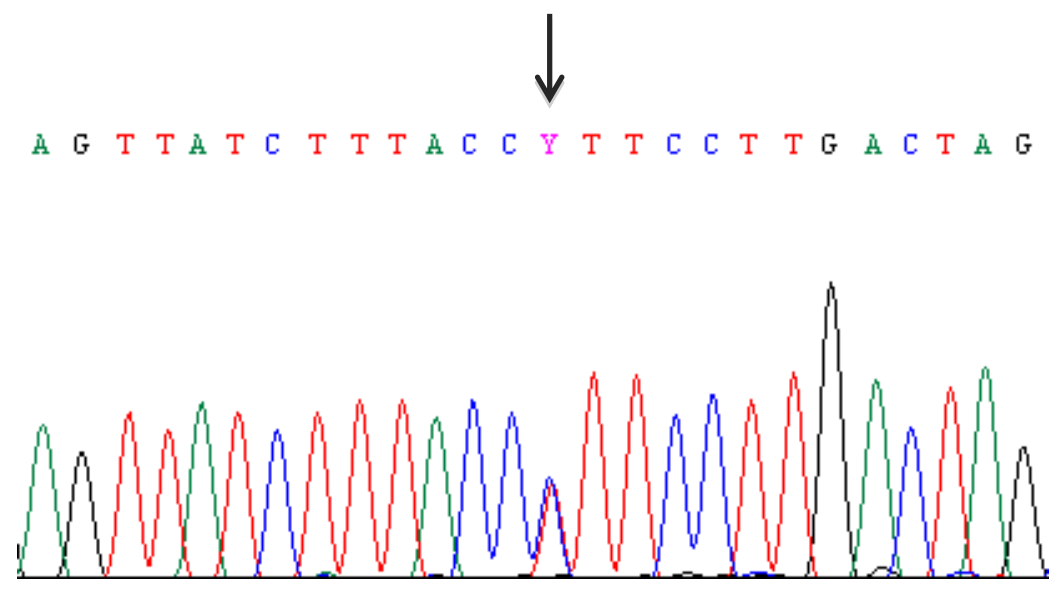

Figura 39: Ejemplo del análisis de las secuencias obtenidas en el programa ChromasPro 1.32. Con la letra $Y$ se representa en heterocigosis $T / C$ uno de los polimorfismos estudiados en este trabajo del promotor de PTGDR, concretamente el presente en posición -549T>C.

La homología con la secuencia depositada en la base de datos GenBank (http://www2.ncbi.nlm.nih.gov/cgi-bin/genbank) se analizó con el programa BLAST de los servidores www2.ebi.ac.uk/fasta3 y www.genome.ad.jp/SIT/SIT.html.

El alineamiento de las secuencias de ADN se llevó a cabo en el programa AlingX (VectorNTI Advance 10, Invitrogen CA, EEUU) (figura 40). 
1

\begin{tabular}{|c|c|c|}
\hline A & (1) & CССGCСTCYCAAAGAGGGGTGTGA---GCTTTTTCTGTGGCGCAGCTTCTCCGCCCGAKCCGCGCGCG \\
\hline B & (1) & CCCGCСTCTCAAAGAGGGGTGTGA---GCTTTTTCTGTGGCGCAGCTTCTCCGCCCGAGCCGCGCGCG \\
\hline C & (1) & CCCGCCTCTCAAAGAGGGGTGTGA---GCTTTTTCTGTGGCGCAGCTTCTCCGCCCGAGCCGCGCGCG \\
\hline $\mathrm{D}$ & (1) & СССGCСтстCAAAGAGGGGTGTGA---GCTTTTTCTGTGGCGCAGCTTCTCCGCCCGAGCCGCGCGCG \\
\hline $\mathbf{E}$ & (1) & СтTTTTCTGTGGCGCAGCTTCTCCGCCCGAKCCGCGCGCG \\
\hline $\mathbf{F}$ & (1) & CCCGCCTCTCAAAGAGGGGTGTGA---GCTTTTTCTGTGGCGCAGCTTCTCCGCCCGAGCCGCGCGCG \\
\hline G & (1) & CCCGCСTCYCAAAGAGGGGTGTGA---GCTTTTTCTGTGGCGCAGCTTCTCCGCCCGAGCCGCGCGCG \\
\hline H & (1) & CCCGCСTCYCAAAGAGGGGTGTGA---GCTTTTTCTGTGGCGCAGCTTCTCCGCCCGAKCCGCGCGCG \\
\hline I & (1) & CCCGCCTCCCAAAGAGGGGTGTGA---GCTTTTTCTGTGGCGCAGCTTCTCCGCCCGAGCCGCGCGCG \\
\hline $\mathbf{J}$ & (1) & CCCGCСTCYCAAAGAGGGGTGTGA---GCTTTTTCTGTGGCGCAGCTTCTCCGCCCGAKCCGCGCGCG \\
\hline $\mathrm{K}$ & (1) & CCCGCCTCTCAAAGAGGGGTGTGA---GCTTTTTCTGTGGCGCAGCTTCTCCGCCCGAGCCGCGCGCG \\
\hline L & (1) & СССGCСTCTCAAAGAGGGGTGTGA---GCTTTTTCTGTGGCGCAGCTTCTCCGCCCGAGCCGCGCGCG \\
\hline M & (1) & A---GCTTTTCTGTGGCGCAGCT' \\
\hline $\mathrm{N}$ & (1) & CCGCCCGAGCCGCGCGCG \\
\hline 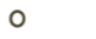 & (1) & $A \mathbf{G}$ \\
\hline
\end{tabular}

Figura 40: Ejemplo del alineamiento de las secuencias obtenidas en el programa AlingX. El alineamiento se realiza a partir de 15 secuencias (A-O) y la secuencia consenso (Cons.). Se representa una región interrumpida con las posiciones $-197 \mathrm{~T}>\mathrm{C}(\mathrm{T} / \mathrm{Y} / \mathrm{C})$ y $-95 \mathrm{G}>\mathrm{T}(\mathrm{G} / \mathrm{K})$ coloreadas dentro del amplicón de 642 pb del promotor de PTGDR, donde se detectan las variantes respecto a la secuencia consenso.

\section{ANÁLISISS RFLP}

El alineamiento de las secuencias obtenidas permitió detectar la presencia de una nueva variante $\mathrm{G}>\mathrm{T}$ en la posición -95 de la región promotora del gen PTGDR (rs41311438), que no había sido estudiada previamente. Dicha variante formaba parte de la región 5' CGPu $\downarrow P i C G$ 3' que identificamos como diana de las enzimas de restricción isoesquizómeras Aval (NewEngland Biolabs, Ipswich, MA, EEUU) y BsoB I (NewEngland Biolabs, Ipswich, MA, EEUU). De manera que la confirmación metodológica de este hallazgo se realizó mediante el estudio de polimorfismos en la longitud de los fragmentos de restricción o RFLP (Restriction Fragment Length Polymorphism) empleando ambas endonucleasas.

La digestión del producto de PCR con estas enzimas permitió analizar dicha mutación ya que reconocen la presencia de una guanina en posición -95 del promotor de PTGDR. El cambio por una timina en esta misma posición supone la 
pérdida del sitio de restricción. Además, en este mismo fragmento se localiza otro punto de corte de estas enzimas (figura 41).

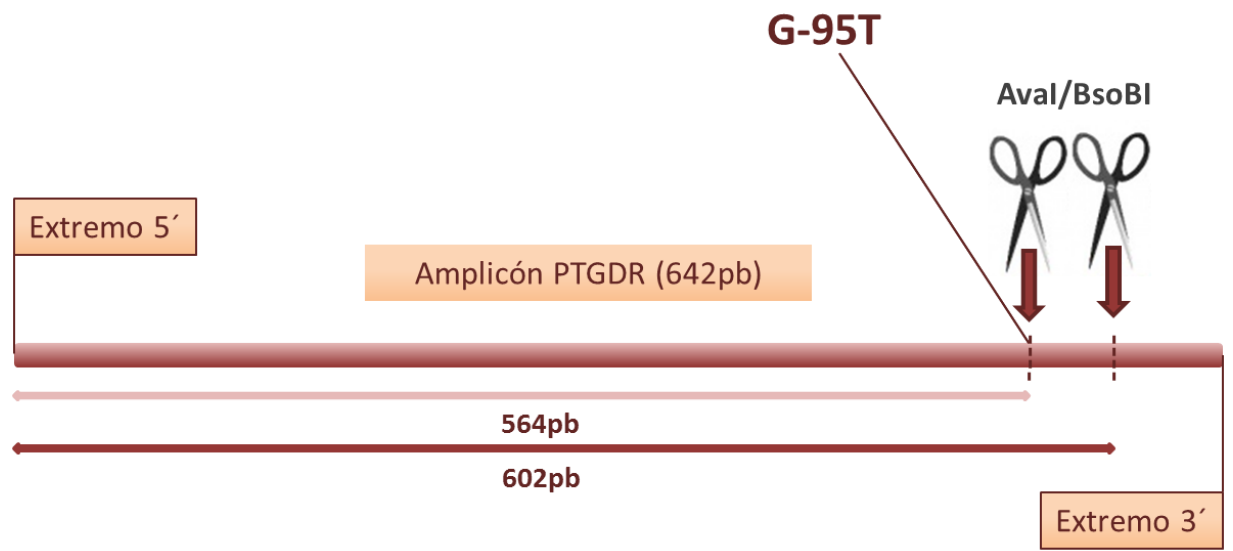

Figura 41: Puntos de restricción de las enzimas Aval y BsoBI en el amplicón de PTGDR a partir de los oligos PTGDR-F y PTGDR-R.

Por otro lado la enzima Aval, a diferencia de BsoBI, es sensible a metilación y no puede reconocer los enlaces fosfodiester del material genético si la pirimidina de la secuencia diana es una citosina metilada en posición 5'. El estudio combinado de ambas enzimas permite el análisis epigenético de los patrones de metilación diferencial en esa región.

Para llevar a cabo la digestión, se mezclaron en paralelo $21,5 \mu \mathrm{L}$ del producto de PCR con 10 unidades de cada enzima de restricción $(1 \mu \mathrm{L})$ y $2,5 \mu \mathrm{L}$ de su tampón correspondiente. Todo ello se incubó durante 6 horas a $37^{\circ} \mathrm{C}$. Los fragmentos generados tras la digestión se separaron por electroforesis horizontal en geles de agarosa de alta resolución al 2,5\% y tampón TAE al 0,5X generando patrones de bandas diferentes correspondientes a los diferentes genotipos para la mutación a estudio (figura 42). 


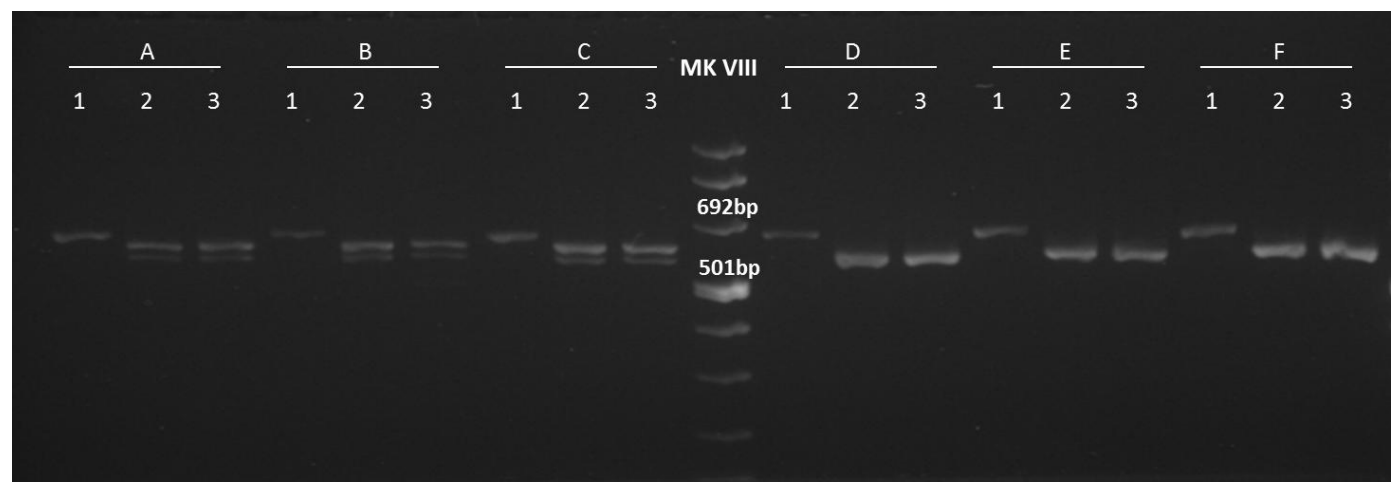

Figura 42: Electroforesis en gel de agarosa al 2,5\% de los fragmentos amplificados por PCR para el estudio del polimorfismo -95G>T del promotor del gen PTGDR. 1: Amplicón sin digerir; 2: Amplicón tras la digestión con Aval; 3: Amplicón tras la digestión con BsoBI. Se observan dos de los genotipos posibles: los individuos A, $B$ y $C$ son heterozigotos $G T$, en los cuales se generan y visualizan en el gel fragmentos de 564 pb y 602 pb; mientras que los individuos D, E y F son homozigotos GG y por tanto sólo se visualizan fragmentos de 564 pb. MK VIII: Patrón de bandas.

\section{CONTROL DE CALIDAD DEL LABORATORÍO}

Durante la realización de este estudio se siguieron las recomendaciones de control de calidad de la European Genetics Quality Network [214] en todos los procedimientos analíticos del mismo.

Los procedimientos de la fase preanalítica garantizaron la identificación inequívoca de las muestras y su correcto almacenamiento. En el momento de su recepción en el laboratorio cada muestra llegó junto con la hoja de recogida de datos clínicos, ambas identificadas con una etiqueta portadora del mismo código de barras. El registro se realizó mediante una identificación secundaria a través de un código de laboratorio alfanumérico, adjudicado a la muestra y a la hoja de datos, a partir del cual se introdujo la información relativa al paciente en una base de datos general almacenada en un ordenador del Servicio de Inmunoalergia con acceso restringido; excluyendo los datos personales 
identificativos. Las hojas de recogida de datos quedaron archivadas a partir de ese momento y las muestras de sangre fueron alicuotadas en criotubos $(1 \mathrm{~mL}$ de sangre por criotubo) debidamente identificados con el número de laboratorio, y almacenadas a $-20^{\circ} \mathrm{C}$. Se dispensaron tres alícuotas por muestra, una para la extracción del ADN y al menos dos para archivo de seguridad; identificadas como una serie $(A 1, A 2, A 3)$.

La extracción del ADN se realizó minimizando el riesgo de contaminación de las muestras en todo momento. Se dispuso de un laboratorio destinado exclusivamente a la extracción del ADN, utilizando en toda circunstancia material estéril y puntas con filtro, además de hacer una revisión de dichas identificaciones en varios puntos del proceso tanto con el sistema automático como con el protocolo manual de extracción.

Se habilitó un área aislada para realizar las PCR en cabina de flujo laminar esterilizada periódicamente con luz UV y se emplearon pipetas dedicadas exclusivamente a esa función y puntas de pipeta con filtro de un solo uso para evitar posibles contaminaciones.

En el estudio se utilizaron controles negativos y marcadores de peso molecular apropiados. Las muestras procedentes de sujetos control y de pacientes se trataron conjuntamente desconociendo su condición en todo el proceso de genotipado. La interpretación de los resultados obtenidos mediante secuenciación se realizó en todos los casos por duplicado. Las secuencias fueron almacenadas en una carpeta en el ordenador de Inmunoalergia con acceso restringido. 


\subsection{ANÁLiSíS FVNCiONAL}

\section{ENSAYOS DE RETARDO EN GEL}

Los ensayos de retardo en gel se realizaron para estudiar el posible papel que desempeñan las variantes del promotor del gen PTGDR; -613C>T, $-549 \mathrm{~T}>\mathrm{C}$, $-441 C>T,-197 T>C$ y $-95 G>T$ en la unión diferencial de factores de transcripción. Esta metodología se basa en la migración de un fragmento del ADN en una electroforesis en gel de poliacrilamida en condiciones no desnaturalizantes cuando éste forma un complejo con proteínas, circunstancia que retarda dicha migración [215] (figura 43). Su aplicación va más allá del estudio de las interacciones entre ADN y proteínas, también se emplea en estudios de interacción entre ARN y proteínas [216], o proteínas y péptidos [217].

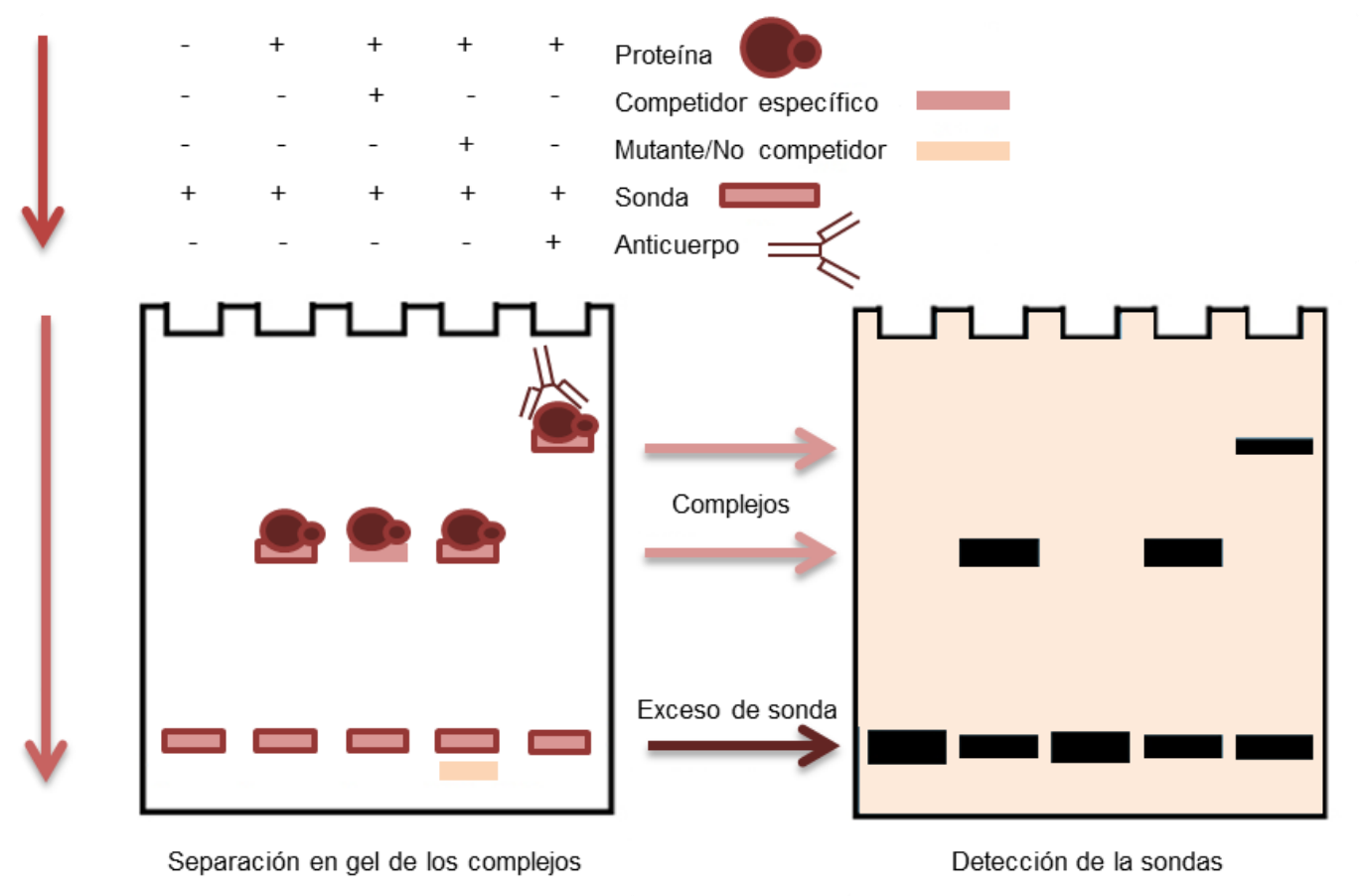

Figura 43. Principio de los estudios de retardo en gel [218]. 
La capacidad de detectar los complejos ADN:proteína reside en la estabilidad de los mismos en cada paso del procedimiento. En la electroforesis, la matriz del gel favorece la estabilización de las uniones entre el ADN y las proteínas [219]. Además se emplea un tampón de electroforesis de baja fuerza iónica para que las interacciones transitorias o muy lábiles se mantengan y puedan ser detectadas. Por otro lado, puede ser necesaria la utilización de competidores de las uniones para establecer la especificidad de las interacciones detectadas. Cuando se utilizan proteínas de unión purificadas no es necesario añadir un competidor inespecífico de $A D N$, mientras que si se emplean extractos totales de proteínas resulta absolutamente esencial añadir un competidor inespecífico de ADN a la reacción de unión. Por otro lado algunas reacciones de unión pueden requerir temperaturas de reacción diferentes.

\section{SISTEMA DIGG GEL SHIIFT KÍT, 2ND GENERATİON}

Para los estudios de retardo en gel se utilizó el sistema DIG Gel Shift Kit 2nd Generation (Roche Applied Science, Mannheim, Alemania) empleado para el marcado no radioactivo de oligonucleótidos. Este método está basado en la molécula conocida como DIG-11-ddUTP, digoxigenina (DIG) unida en la posición C5 de la uridina del dideoxy-uracil-trifosfato (ddUTP) mediante un brazo espaciador de 11 átomos de carbono (figura 44). La digoxigenina es un esteroide procedente de las hojas y flores de Digitalis purpurea y Digitalis lanata, única fuente natural de este compuesto. Los anticuerpos anti-digoxigenina no reconocen ni se unen a ningún otro material biológico [220].

El marcado de los oligonucleótidos se realiza mediante la acción de una transferasa terminal recombinante que cataliza la unión del DIG-11-ddUTP en los extremos $3^{\prime}$ libres de los fragmentos de ADN. La detección del marcaje con este esteroide se realiza con un anticuerpo policlonal anti-digoxigenina (Anti-DIG) 
conjugado con fosfatasa alcalina (FA). El sustrato de la enzima empleado es un compuesto quimioluminiscente conocido como CSPD (3-(4-metoxi-espiro[1,2dioxetano-3,2'-(5'-cloro)triciclo[3.3.1.1 ${ }^{3,7}$ decan]-4-il]fenil fosfato) [221]. La desfosforilación enzimática del CSPD por la FA produce un anión fenolato que se descompone y emite luz, la cual se registra en películas de rayos $\mathrm{X}$ o en cámaras o instrumentos que detectan esta señal.

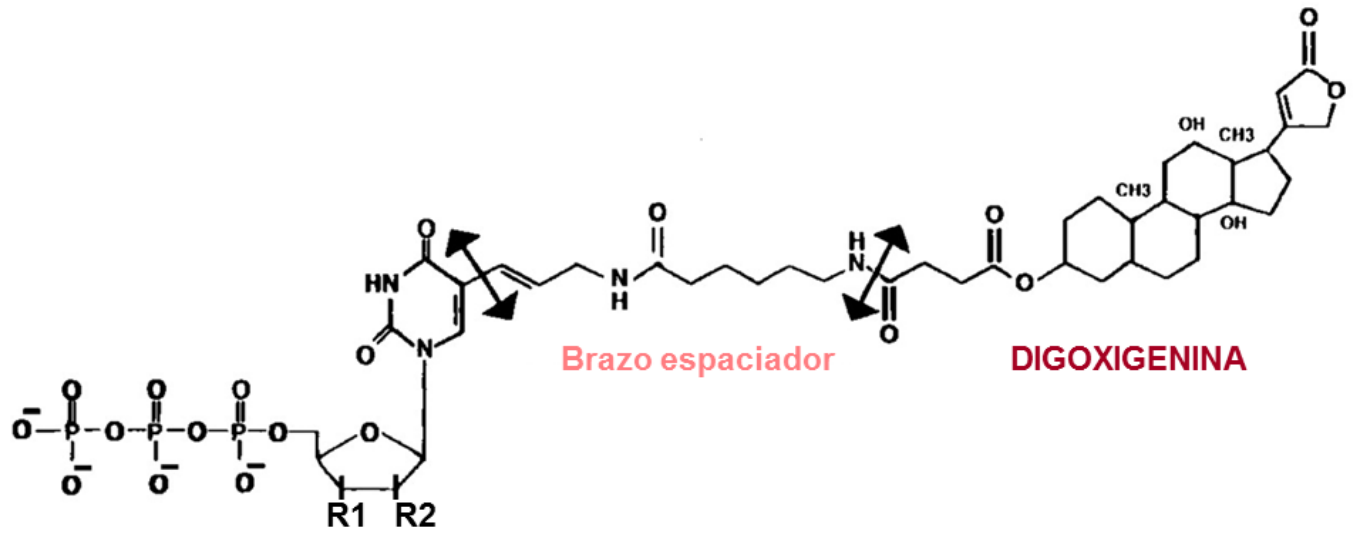

Figura 44. Molécula de digoxigenina 11-uridin-trifosfato. La digoxigenina se une a través del brazo espaciador a la uridina $(R 1=\mathrm{OH}, \mathrm{R} 2=\mathrm{OH})$, deoxiuridina $(\mathrm{R} 1=\mathrm{OH}$, $\mathrm{R} 2=\mathrm{H})$ o dideoxiuridina $(\mathrm{R} 1=\mathrm{H}, \mathrm{R} 2=\mathrm{H})$ para formar las moléculas de DigoxigeninaUTP, Digoxigenina-dUTP y la Digoxigenina-ddUTP respectivamente [222].

La sensibilidad de la detección del marcaje con DIG depende del método empleado para visualizar los anticuerpos anti-DIG conjugados. La quimioluminiscencia es la metodología más rápida y sensible para ello, y el CSPD es uno de los sustratos más sensibles del mercado [220, 223].

\section{FRAGMENTOS DE ADN}

Los fragmentos de ADN lineal de doble cadena (ADNds) empleados se obtuvieron a través del anillamiento de sus respectivos oligonucleótidos de 
cadena sencilla (oligonucleótidos ${ }_{s s}$ ). Estos fueron diseñados a partir de la secuencia del promotor de PTGDR depositada en la base de datos GenBank (http://www2.ncbi.nlm.nih.gov/cgi-bin/genbank), y adquiridos comercialmente.

El estudio de cada variante génica; $-613 \mathrm{C}>\mathrm{T},-549 \mathrm{~T}>\mathrm{C},-441 \mathrm{C}>\mathrm{T},-197 \mathrm{~T}>\mathrm{C}$ y $-95 G>T$, requirió la síntesis de dos parejas de oligonucleótidos ${ }_{s s}$, una contenía la posición conservada y la otra la base mutada. Cada pareja estaba compuesta por un cebador forward representado con la letra $f y$ un cebador reverse con la $r$, complementarios entre sí. Su identificación se hizo a partir de la base y el polimorfismo correspondiente (apéndice). En todos los casos, el tamaño de los fragmentos de ADNds resultantes fue de 30 a $40 \mathrm{pb}$, caracterizados por la presencia de adeninas (A) libres en sus extremos $3^{\prime}$ para el marcaje de la molécula de doble cadena con DIG-11-ddUTP (figura 45) [224].

Los oligonucleótidos $s_{s s}$ fueron suministrados como un liofilizado y posteriormente fueron reconstituidos a $100 \mu \mathrm{M}$ con agua destilada libre de nucleasas (Promega, Madison, WI, EEUU).

$$
\begin{aligned}
& \text { 613fC }\left(5^{\prime} \rightarrow 3^{\prime}\right) \text { (Dig.) GATGACCGTGAATGCCCCAAATTGCGCTGATCTAG } \\
& 613 \mathrm{rG}\left(3^{\prime} \rightarrow 5^{\prime}\right)
\end{aligned}
$$

Figura 45: Representación del oligonucleótido de doble cadena $613 \mathrm{C} / \mathrm{G}$. Se esquematiza la unión por complementariedad del ddUTP unido a la digoxigenina a las adeninas libres en los extremos 3 'de la molécula gracias a la acción de la transferasa terminal. 


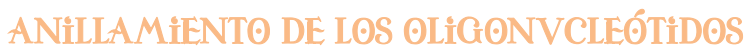

La síntesis de las moléculas de ADNds se llevó a cabo mediante el anillamiento de cada oligonucleótido ${ }_{s s}$ con su complementario. Se realizaron dos reacciones de anillamiento por cada pareja a las concentraciones de $100 \mu \mathrm{M}$ y 4 $\mu \mathrm{M}$; diluyéndolos previamente en TEN Buffer (10 mM Tris, 1 mM EDTA, 0,1 M $\mathrm{NaCl}$, pH 8,0). Para ello se prepararon mezclas equimolares de los oligonucleótidos $_{\mathrm{ss}}$ de cada pareja, que fueron incubadas durante $10 \mathrm{~min}$ a $95^{\circ} \mathrm{C}$, tras los cuales se aplicó una rampa de temperatura para conseguir un enfriamiento lento a $20^{\circ} \mathrm{C}$, todo ello en el termociclador de MWG-BIOTECH (Biothech, Ebersberg, Alemania). Una vez obtenidos, los oligonucleótidos de doble cadena (oligonucleótido ${ }_{\mathrm{ds}}$ ) se almacenaron a $-20^{\circ} \mathrm{C}$ o, en el caso de aquellos a una concentración $4 \mu \mathrm{M}$, se continuó con su etiquetado.

\section{CONTROL POSíTíVO}

Como control positivo de estos ensayos se empleó un oligonucleótido ds que contenía en su secuencia el sitio de unión de la proteína Oct2A (figura 46). El DIG Gel Shift Kit, aporta este fragmento marcado con DIG-ddUTP y sin marcar. En este trabajo se utilizó el oligonucleótido control sin marcar, para evaluar el ensayo en todos y cada uno de sus pasos.

$$
\begin{aligned}
& 5^{\prime} \text { - GTACGGAGTATCCAGCTCCGTAGCATGCAAATCCTCTGG - } 3^{\prime} \\
& 3^{\prime}-\text { CCTCATAGGTCGAGGCATCGTACGTTTAGGAGACCAGCT- } 5^{\prime}
\end{aligned}
$$

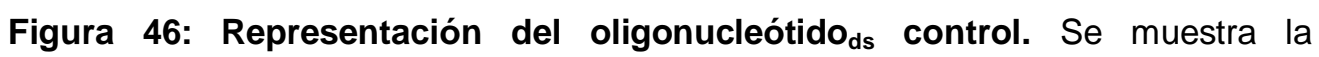
secuencia de unión de la proteína Oct2A (rosa). 


\section{MARCAD○ DE LOS OLIGGONVCLEO゚TIIDOS}

El marcaje de los oligonucleótidos ${ }_{d s}$ se llevó a cabo en un volumen final de $20 \mu \mathrm{L}$ a partir de los reactivos contenidos en el kit. En cada reacción se añadieron $4 \mu \mathrm{L}$ de Labeling buffer (1 M Cacodilato potásico, 0,125 M Tris- $\mathrm{HCl}$, $125 \mathrm{mg} / \mathrm{ml}$ BSA, pH 6,6), $4 \mu \mathrm{L}$ de $\mathrm{CoCl}_{2}$ solution $(25 \mathrm{mM} \mathrm{CoCl}$ ), $1 \mu \mathrm{L}$ de DIGddUTP solution ( $1 \mathrm{mM}$ DIG-11-ddUTP en agua bidestilada), $1 \mu \mathrm{L}$ de Terminal transferase recombinant $(60 \mathrm{mM}$ K-fosfato, $\mathrm{pH} 7,2,150 \mathrm{mM} \mathrm{KCl}, 1 \mathrm{mM}$ 2-Mercaptoetanol, 0,5\% Tritón $\mathrm{X}-100,50 \%$ glicerol, $400 \mathrm{U} / \mu \mathrm{L}$ de transferasa terminal recombinante) y 40 pmol de oligonucleótido ${ }_{\mathrm{ds}}$ ó 4 pmol en el caso del oligonucleótido control. La mezcla se incubó a $37^{\circ} \mathrm{C}$ durante 15 minutos; transcurrido este tiempo la reacción se interrumpió mediante la adición de $2 \mu \mathrm{L}$ de EDTA 0,2 M (pH 8,0). Finalmente, se añadieron $3 \mu \mathrm{L}$ de agua destilada libre de nucleasas (Promega, Madison, WI, EEUU) para lograr una concentración final de oligonucleótido ${ }_{d s}$ marcado de $1,6 \mathrm{pmol} / \mu \mathrm{L}$ y de $0,16 \mathrm{pmol} / \mu \mathrm{L}$ para el control.

\section{PVRIFİCACIÓN DE LOS OLIGONVCLEÓTIDOS MARCADOS}

Los oligonucleótidos $_{\mathrm{ds}}$ ya marcados se procesaron mediante el sistema comercial Illustra ProbeQuant G-50 Micro columns (GE Healthcare, Oslo, Noruega) (figura 47). Mediante filtración en una columna de sefarosa, los fragmentos de ADN marcados de un tamaño superior a $20 \mathrm{pb}$ se separaron del exceso de DIG-ddUTP. Las moléculas de un tamaño superior a los poros de esta resina quedan excluidas de la matriz del gel como ocurre con los oligonucleótidos $_{\mathrm{ds}}$ marcados, mientras que las de menor tamaño, en este caso los nucleótidos marcados sobrantes, quedan retenidas en la columna y por tanto no aparecen en el eluido. 


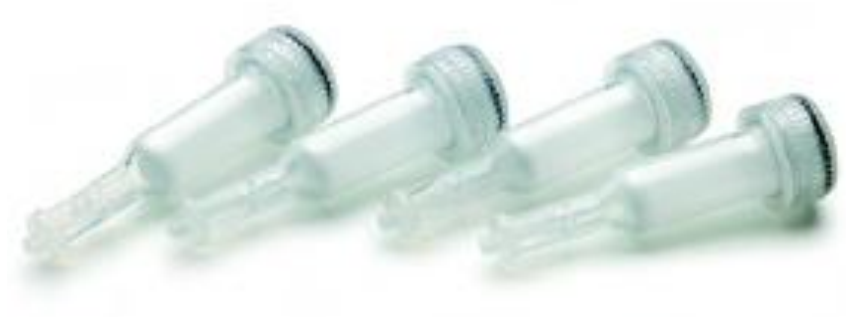

Figura 47. Micro columnas del kit Illustra ProbeQuant G-50 Micro columns. Se observa el extremo terminal de la columna que se desecha para eliminar el tampón STE en que va equilibrada la sefarosa.

Las muestras $(25 \mu \mathrm{L})$ se diluyeron hasta un volumen de $50 \mu \mathrm{L}$ con la solución Probe Buffer type 1 (150 mM STE: 10 mM Tris-HCl, 1 mM EDTA y 150 $\mathrm{mM} \mathrm{NaCl}, \mathrm{pH}$ 8,0). La resina de sefarosa (Prepacked Sephadex ${ }^{\mathrm{TM}}$ G-50 DNA Grade) contenida en la micro columna y pre-equilibrada con un tampón (150 mM STE con $0,15 \%$ Kathon CG/ICP Biocide como conservante) se resuspendió mediante vortex y una pieza auxiliar del sistema. Tras romper el extremo terminal de la columna se eliminó dicho tampón mediante una centrifugación a $735 \mathrm{~g}$ durante 1 minuto. Se aplicó la muestra sobre la resina, colocando un nuevo tubo de recolección y, después de 2 minutos de centrifugación a 735 g, se recogió el oligonucleotido $_{\mathrm{ds}}$ marcado y purificado en la misma solución de preparación de la muestra (150 mM STE).

Los oligonucleotidos $_{\mathrm{ds}}$ marcados y purificados se almacenaron a $-20^{\circ} \mathrm{C}$ con la identificación en la que constaba la fecha de su etiquetado. La estabilidad del marcaje en estas condiciones fue de 7 a 9 días.

\section{DETER MINACIÓN DE LA EFICACIA DEL MARCADO}

La eficiencia de la reacción de marcado se comprobó mediante el análisis de la señal de una serie de diluciones de los oligonucleótidos ${ }_{d s}$ marcados, incluido 
el control. Se prepararon 4 diluciones seriadas al 1/1, 1/10, 1/100 y 1/1000 en TEN Buffer, empleando este mismo tampón como control negativo. Se aplicaron $2 \mu \mathrm{L}$ de cada una de las diluciones y del control negativo en una membrana de nylon, y se determinó la cantidad de ADN marcado mediante la comparación de la serie, considerándose el marcaje como óptimo siempre que la dilución 1/1000 era visible.

\section{EXTRACTO PROTEICO}

Se empleó un extracto comercial de proteínas nucleares procedentes de leucocitos de sangre periférica de un varón sano (AMS Biotechnology, Osfordshire, Reino Unido). La concentración de las mismas era de $1 \mathrm{mg} / \mathrm{ml}$ y el buffer que las contenía incluía HEPES (pH 7,9), glicerol, $\mathrm{NaCl}, \mathrm{MgCl}_{2}$, EDTA y un conjunto de inhibidores de proteasas.

Para el ensayo control se utilizó la proteína Oct2A del DIG Gel Shift Kit a una concentración de 25-75 $\mathrm{ng} / \mu \mathrm{L}$. Oct2A reconoce específicamente la secuencia anteriormente citada del oligonucleótido control del mismo sistema.

\section{$>$ REACCi@́N DE VNiఠ́N}

Las condiciones de la reacción de unión entre las proteínas y el ADN, como la concentración de sales y el pH pueden determinar las interacciones entre

ellos, de manera que puede ser necesario añadir $\mathrm{Mg}^{2+}, \mathrm{Zn}^{2+}, \mathrm{Ca}^{2+}$, detergente o espermidina. En los ensayos de retardo en gel de este trabajo, la poli-L-lisina empleada permitió la optimización de la formación de complejos ADN:proteína específicos, ya que los péptidos sencillos pueden aumentar la aparente afinidad de unión al DNA. Como competidor inespecífico de las uniones entre el ADN y las proteínas se empleó poli $[\mathrm{d}(\mathrm{I}-\mathrm{C})]$ si el fragmento era rico en Guanina $(\mathrm{G})$ y 
Citosina $(C)$ o poli $[d(A-T)]$ si el fragmento era rico en Adenina $(A)$ y Timina $(T)$. El competidor específico utilizado en cada ensayo fue el mismo fragmento de ADNds a una concentración de $100 \mu \mathrm{M}$ y sin marcar, denominado competidor; que desplaza la formación de los complejos entre los fragmentos marcados y las proteínas. En esta línea puede utilizarse la albúmina para aumentar la formación de los complejos específicos ADN:proteína. Del mismo modo, el orden de la adición del oligonucleótido marcado y del extracto nuclear puede ejercer mucha influencia en la especificidad de las interacciones entre ADN y proteínas [224].

Cada ensayo de retardo comprendió 3 reacciones. La primera, con el

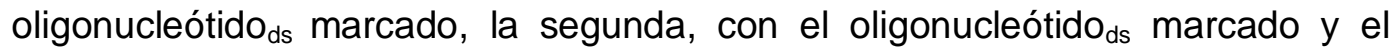
extracto proteico y la tercera, con el oligonucleótido $\mathrm{ds}_{\mathrm{s}}$ marcado, el extracto

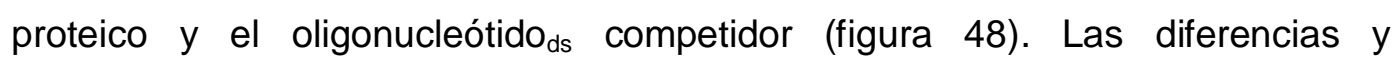
similitudes entre ellos permitieron la detección de las uniones específicas entre los fragmentos de ADN estudiados y la proteína o proteínas nucleares.
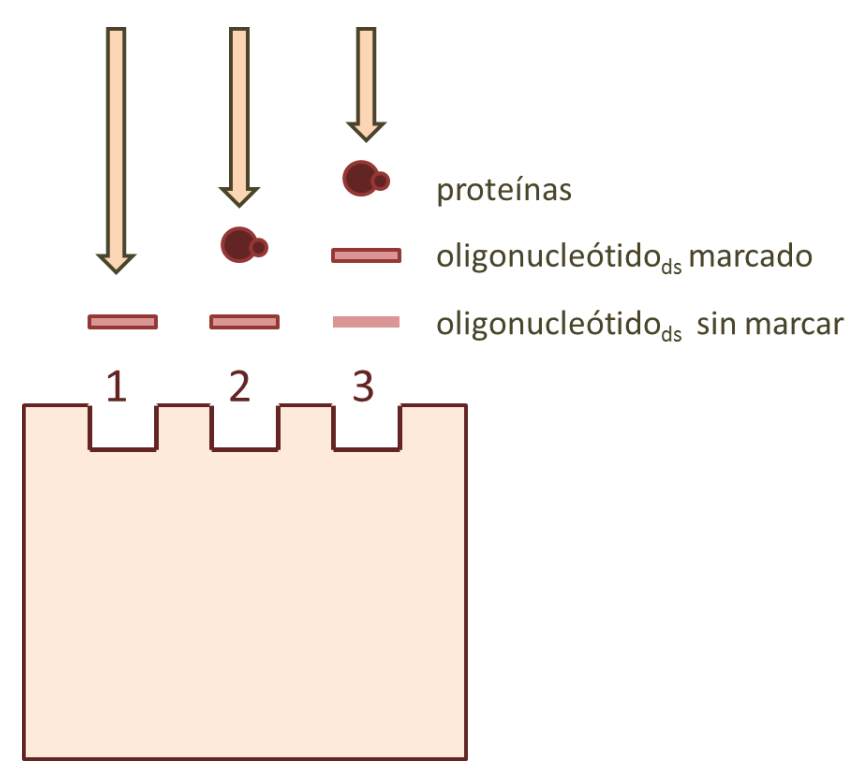

Figura 48. Esquema del ensayo de retardo en gel. Representación del contenido de las tres reacciones de unión que serán analizadas por electroforesis. 
Se preparó un tubo eppendorf debidamente identificado para cada reacción de unión. El tampón contenía HEPES a $20 \mathrm{mM}(\mathrm{pH} 7,6)$, EDTA a $1 \mathrm{mM}$, $\left(\mathrm{NH}_{4}\right)_{2} \mathrm{SO}_{4}$ a $10 \mathrm{mM}$, DTT a $1 \mathrm{mM}$, Tween 20 al 0,2\% (peso/volumen), $\mathrm{KCl}$ a $30 \mathrm{mM}$, poli $[\mathrm{d}(\mathrm{I}-\mathrm{C})]$ a $0,05 \mu \mathrm{g} / \mu \mathrm{L}$, y poli $\mathrm{L}$-lisina a $0,005 \mu \mathrm{g} / \mu \mathrm{L}$ en un volumen final de $20 \mu \mathrm{L}$. Se añadieron $60 \mathrm{fmol}$ de oligonucleótidos ${ }_{\mathrm{ds}}$ marcados con Digoxigenin-11-ddUTP y $31 \mathrm{fmol}$ del oligonucleótido control y, como último componente, se añadieron $2 \mu \mathrm{g}$ del extracto de proteínas nucleares. La cantidad de oligonucleótido $\mathrm{ds}_{\mathrm{ds}}$ competidor fue de $1 \mathrm{nmol}$ y de 4 pmol para el oligonucleótido control.

Las reacciones de unión fueron mezcladas brevemente mediante vortex y un pulso de centrífuga e incubadas durante 30 minutos a temperatura ambiente $\left(25^{\circ} \mathrm{C}\right)$ y posteriormente colocadas en hielo antes de ser aplicadas en el gel de electroforesis.

\section{ELECTR OFORESíS EN GEL DE POLIACRILAMIDAA}

Los complejos ADN:proteína fueron separados mediante electroforesis en condiciones no desnaturalizantes en geles de poliacrilamida al 8\% y tampón TBE al 0,5X. La concentración de acrilamida de los geles depende del tamaño del oligonucleótido o de los complejos formados con la proteína/s. Para su preparación se utilizó Acrilamida/Bisacrilamida 29/1 al 40\% (peso/volumen) (National Diagnostics U.S.A., Atlanta, Georgia, EEUU); tampón TBE Buffer al 10X (Promega, Madison, WI, EEUU), compuesto por 890 mM de Tris-borato, 890 mM de ácido bórico, 20 mM de EDTA y pH 8,2-8,4; Persulfato amónico (AMPS) al $10 \%$ (peso/volumen) (Sigma-Aldrich Co. LLC, USA); y TEMED (TetraMetilEtilenDiamida) (GE Healthcare, Oslo, Noruega), que se diluyeron con agua destilada. 


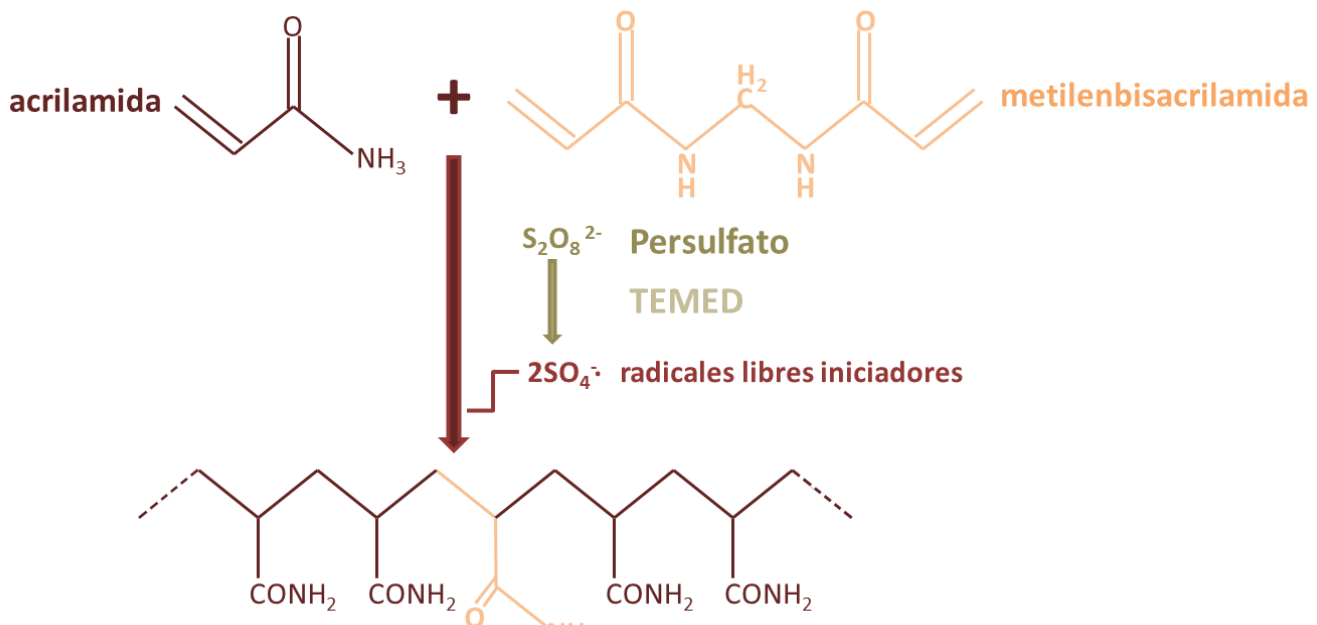

POLIMERIZACIÓN<smiles>CCC(CC(CC(CC(CC(CC)C(N)=O)C(N)=O)C(N)=O)C(N)=O)C(N)=O</smiles>

Figura 49. Polimerización de la acrilamida y bisacrilamida.

La preparación de los geles se realizaba el día anterior al que iban a ser utilizados, para asegurar su completa polimerización. También se estableció como necesaria la limpieza de los cristales con etanol $100 \%$ puro para eliminar posibles restos de poliacrilamida. La mezcla se realizó en frío y agitación con el fin de evitar una polimerización temprana de la poliacrilamida, añadiendo en último lugar el AMPS y el TEMED. EI AMPS se utiliza como catalizador de la copolimerización de los geles de acrilamida y bisacrilamida. La reacción de polimerización se produce por los radicales libres generados en reacciones de óxido-reducción en las que el TEMED participa como co-catalizador del AMPS (figura 49) [220]. Se debe utilizar la menor concentración posible de catalizadores que permita la polimerización en un tiempo óptimo. 
Con ayuda de una pipeta pasteur la mezcla se vertió entre los cristales molde colocados en las pinzas evitando la formación de burbujas, y a continuación se encajó el peine de pocillos.

Una vez polimerizado el gel de poliacrilamida fue pre-corrido en TBE al 0,5X a $200 \mathrm{~V}$ y $4^{\circ} \mathrm{C}$ durante 2 horas con el fin de eliminar los restos de AMPS, urea y poliacrilamida residual y conseguir la aplicación de las muestras sin difusión. Posteriormente se aplicaron en los pocillos del gel las muestras previamente mezcladas con $5 \mu \mathrm{L}$ de tampón de carga Loading buffer con azul de bromofenol $(0,25 \mathrm{X}$ TBE, $60 \%$ glicerol). El azul de bromofenol es una molécula pequeña y coloreada empleada para seguir el frente de la electroforesis y no perder las muestras. El gel se sometió a una corriente eléctrica de $200 \mathrm{~V}$ durante 100 minutos a $4^{\circ} \mathrm{C}$ evitando el sobrecalentamiento del mismo.

\section{ELECTROTRANSFERENCIA}

La electrotransferencia del ADN desde geles de poliacrilamida a membranas de nylon positivamente cargadas de 0,45 $\mu \mathrm{m}$ de poro (Roche Applied Science, Mannheim, Alemania), se realizó utilizando un sistema de transferencia húmeda (PowerPac ${ }^{\mathrm{TM}}$ Basic Bio-Rad, California, EEUU) y TBE al 0,5X como tampón de transferencia. Este tipo de transferencia es el método de elección en el caso de pequeños fragmentos de ADN separados por electroforesis en geles de poliacrilamida; los ácidos nucleicos de menos de $50 \mathrm{pb}$ se unen a las membranas de nylon cargadas en condiciones de baja fuerza iónica del tampón [225]. Las membranas de nylon positivamente cargadas gracias a los grupos amino que contienen presentan mayor capacidad de unión de los ácidos nucleicos, lo que en ocasiones trae consigo mayor ruido de fondo en la hibridación [220]. 
Las membranas fueron previamente humedecidas durante 5 minutos en el tampón de transferencia antes de ser puestas en contacto con el gel, así como las hojas de papel Whatman 3MM y las almohadillas. La electrotransferencia se realizó a 4ํㅡ y 400 miliamperios durante 30 minutos.

La fijación de los ácidos nucleicos a las membranas de nylon se realizó con luz UV aplicando $120 \mathrm{~mJ}$ en el crosslinker BIO-LINK® BLX-E254 (Vilber Lourmat, Cedex, Francia).

\section{$>$ DETECCiÓN POR QVíMIOLVMİNiSCENCIA}

Para la detección de los oligonucleótidos marcados se empleó, además del sistema DIG Gel Shift Kit 2nd Generation, el kit DIG Wash and Block Buffer Set (Roche Applied Science, Mannheim, Alemania) que contiene las soluciones de bloqueo, lavado y detección del marcaje con digoxigenina.

Una vez hibridado y fijado el ADN en la membrana de nylon, está se incubó durante 2 minutos con la solución de lavado (dilución del Washing buffer 10X al $1 \mathrm{X}$ con agua destilada) y se saturó con una solución de bloqueo (dilución del Blocking solution 10X al $1 \mathrm{X}$ en ácido maléico). El bloqueo de los sitios de unión inespecíficos de la membrana se llevó a cabo a temperatura ambiente durante 30 minutos y en agitación suave. A continuación, se incubó la membrana con el anticuerpo anti-digoxigenina (anti-digoxigenin-AP: $750 \mathrm{U} / \mathrm{ml}$ de fragmentos Fab de anticuerpo policlonal anti-digoxigenina conjugados con FA) diluido al 1:10.000 en solución de bloqueo; a temperatura ambiente durante 30 minutos y en agitación suave. Posteriormente, y con objeto de eliminar el exceso de anticuerpo unido inespecíficamente, se realizaron 2 lavados con solución de lavado de 15 minuntos cada uno. Por último la membrana se acondicionó a temperatura ambiente durante 5 minutos y en agitación con la solución de detección (dilución al 1X con agua destilada del Detection buffer 10X: 1M Tris- 
$\mathrm{HCl} \mathrm{pH} 9,5,1 \mathrm{M} \mathrm{NaCl}$ ); mediante la cual se ajusta el pH a 9,5, condición necesaria para la reacción quimioluminiscente con el CSPD. Dicho sustrato se diluyó al 1:100 en solución de detección en un volumen total de $1 \mathrm{~mL}$, en el cual se incubó la membrana durante 5 minutos y a temperatura ambiente. Para ello, la membrana se envolvió en un plástico transparente que permitió el reparto del CSPD por toda la superficie de cara de la membrana del ADN, evitando la presencia de burbujas de aire. Una vez eliminado el exceso de sustrato, la membrana se colocó inmediatamente en un segundo plástico transparente y sin burbujas; y se incubó durante 10 minutos a $37^{\circ} \mathrm{C}$ para activar la reacción quimioluminiscente del CSPD. El compuesto luminiscente generado impresionó una película autorradiográfica de alta sensibilidad (Kodak) a la que fue expuesta la membrana, y su revelado se llevó a cabo con los reactivos "Kodak® processing chemicals for autoradiography films" (Sigma-Aldrich Co. LLC, EEUU).

\section{ESTVDi゚ ÍN SÍLÍCO DE LAS VARİANTES}

Un segundo abordaje para el estudio de las variantes del promotor del gen PTGDR; -613C>T, $-549 \mathrm{~T}>\mathrm{C},-441 \mathrm{C}>\mathrm{T},-197 \mathrm{~T}>\mathrm{C}$ y $-95 \mathrm{G}>\mathrm{T}$ se realizó a través del análisis in sílico de los sitios de unión a factores de transcripción en dicha región mediante los programas: EIDorado (Genomatix Software GmbH, http://www.genomatix.de/en/index.html) y Transcription Element Search System (TESS, http://www.pcbi.upenn.edu/tess). Ambos programas emplean distintos algoritmos mediante los cuales proponen una serie de factores de transcripción candidatos a interaccionar con la secuencia introducida. En este estudio fueron evaluadas tanto las posiciones conservadas como los polimorfismos con el fin de comparar los resultados obtenidos de estos análisis. 


\section{IDENTİFiCACíǿN DE FACTORES DE TRANSCRİPCíீ́N}

A raíz de los ensayos de retardo en gel en las posiciones del promotor de PTGDR; $-613 \mathrm{C}>\mathrm{T}, \quad-549 \mathrm{~T}>\mathrm{C}, \quad-441 \mathrm{C}>\mathrm{T}, \quad-197 \mathrm{~T}>\mathrm{C}$ y $-95 \mathrm{G}>\mathrm{T}$, se propuso la identificación de las proteínas unidas a estos puntos a través de distintas estrategias.

\section{PVRIIFÍCACIÓN DE PROTEÍNAS DE VNiீ́N AL ADN}

Uno de los abordajes para la identificación de las proteínas formadoras de complejos con el ADN en los ensayos de retardo fue precisamente a través de las moléculas de $\mathrm{ADN}$ que contenían estas secuencias, en concreto de la región en torno a la posición $-613 C>T$ de PTGDR. Para ello se eligió el sistema "DNAbinding Protein Purification Kit' (Roche Applied Science, Mannheim, Alemania), indicado para la purificación de proteínas que se unen específicamente a determinadas secuencias de ADN. Este proceso se fundamenta en la utilización de partículas magnéticas marcadas con estreptavidina a las cuales se une un pequeño oligonucleótido marcado con biotina en su extremo 3'. A estos complejos se liga una molécula de ADN que contiene múltiples copias en tándem de la secuencia de interés y que se conoce como concatémero. Tras la incubación con el extracto de proteínas, quedan unidas a dicha molécula aquellas proteínas con unión específica a la secuencia determinada de ADN, (figura 50). Tras una serie de lavados, la recuperación o purificación de las proteínas unidas se lleva a cabo a través de un tampón de elevada fuerza iónica.

Las condiciones de las reacciones de unión entre las proteínas y el ADN son determinantes en la medida en la que pueden interferir en la interacción entre ambos, tal y como ocurre en los ensayos de retardo en gel. Puede ser necesario ajustar la concentración de sales y el pH en función de las proteínas. Del mismo 
modo que en los ensayos de retardo en gel, la poli-L-lisina empleada permitió la optimización de la formación de complejos ADN:proteína específicos y el poli $[\mathrm{d}(\mathrm{I}-\mathrm{C})]$ eliminó las uniones inespecíficas entre el ADN y las proteínas.

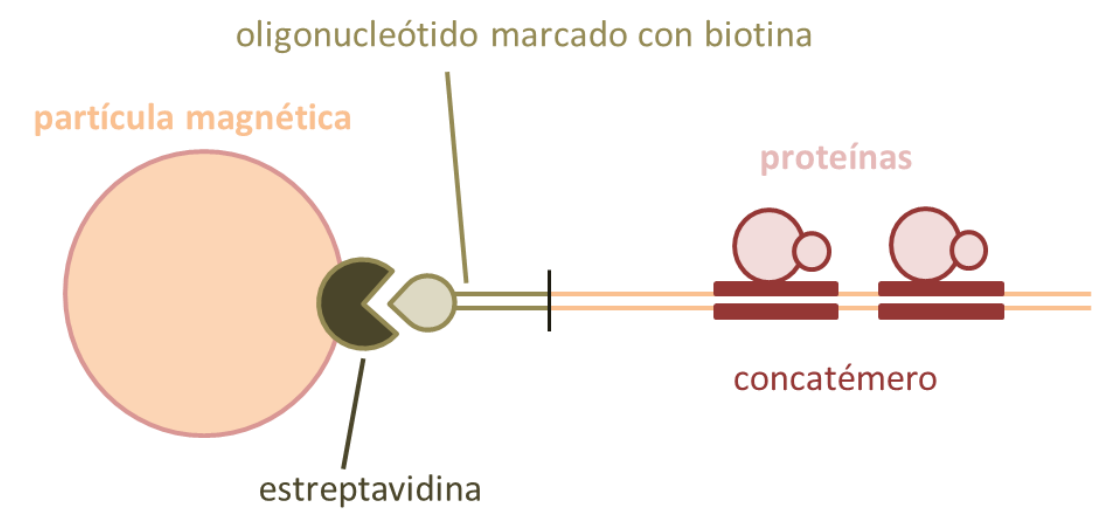

Figura 50. Principio de los ensayos de purificación con el DNA-binding Protein Purification Kit.

\section{CONCATÉMEROS}

Los fragmentos de ADNds que contenían la secuencia en torno al polimorfismo $-613 \mathrm{C}>\mathrm{T}$ repetida $\mathrm{n}$ veces fueron obtenidos a través una reacción de PCR auto-cebada (figura 51). Para ello, y a partir de la secuencia del promotor de PTGDR depositada en la base de datos GenBank (http://www2.ncbi.nlm.nih.gov/cgi-bin/genbank), se diseñaron 2 parejas de

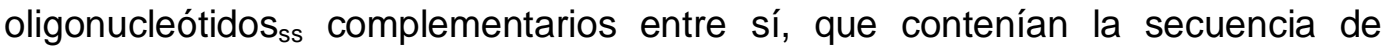
interés repetida en tándem 2,5 veces: una contenía la posición conservada CG y la otra el polimorfismo TA. Sus extremos 5' estaban fosforilados con el propósito de que estos oligonucleótidos actuaran de molde y cebador al mismo tiempo. Cada pareja estaba compuesta por un cebador forward representado con la letra f y un cebador reverse con la $r$, todos ellos identificados con el prefijo "PH" y la base del polimorfismo correspondiente (apéndice). 


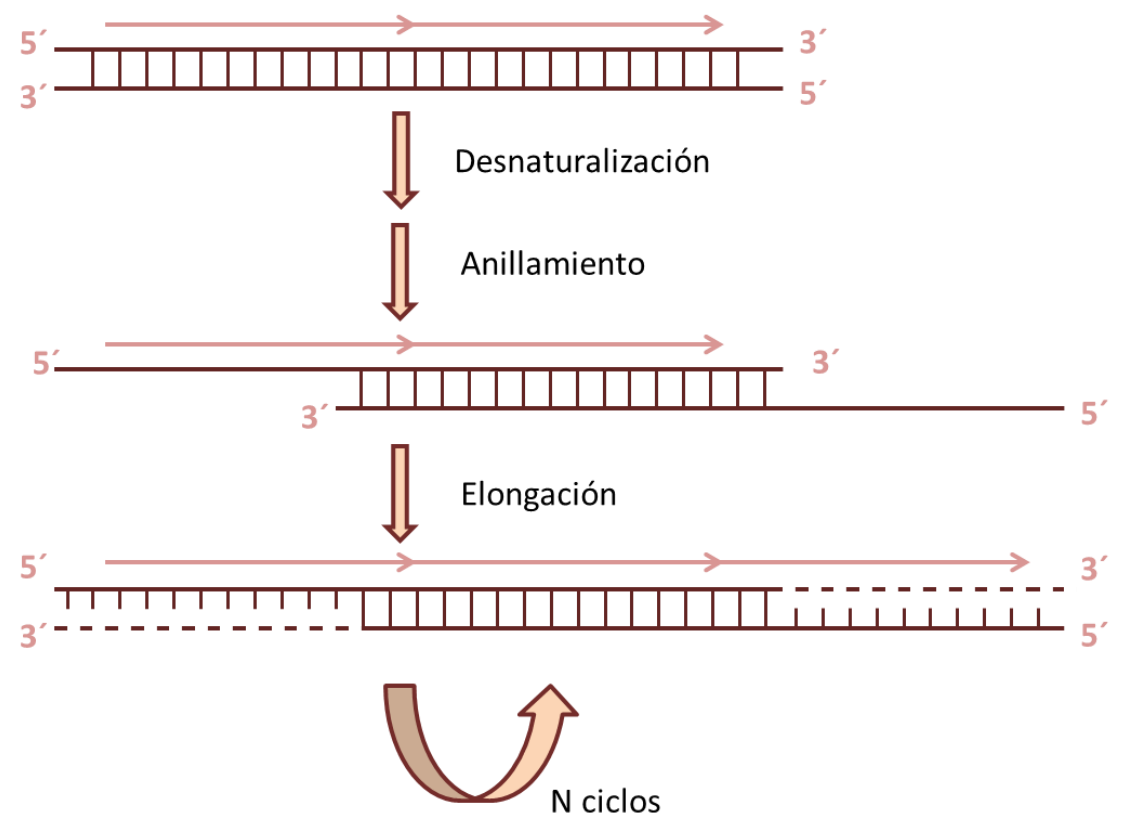

Figura 51. Representación de la metodología de la PCR auto-cebada. Se esquematiza mediante las flechas rosas la región repetida 2,5 veces en la secuencia de los oligonucleótidos, que actúan a la vez de molde y cebador.

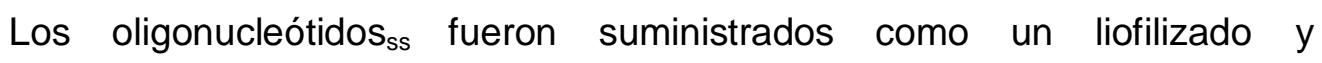
posteriormente reconstituidos a $100 \mu \mathrm{M}$ con agua destilada libre de nucleasas (Promega, Madison, WI, EEUU) y almacenados a $-20^{\circ} \mathrm{C}$.

Como control positivo se empleó un oligonucleótido ${ }_{\mathrm{ds}}$ que contenía en su secuencia el sitio de unión de la proteína Oct2A repetido 2 veces (figura 52). El DNA-binding Protein Purification Kit contiene este fragmento, así como la proteína Oct2A purificada.

5' -ACGGATCCAGATGCAAATACGGATCCAGATGCAAATACGGATCCAG- 3' 3'-TGCCTAGGTCTACGTTTATGCCTAGGTCTACGTTTATGCCTAGGTC- 5'

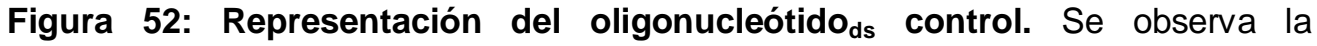
secuencia de unión de la proteína Oct2A que se encuentra duplicada en este fragmento (rosa). 


\section{CONCATEMERIZZACiÓN}

La PCR auto-cebada se llevó a cabo mediante el kit Pwo SuperYield DNA Polymerase, dNTPack (Roche Applied Science, Mannheim, Alemania), indicado para amplificaciones del ADN de alta fidelidad y amplicones de gran tamaño, de hasta $3 \mathrm{~Kb}$. Todo ello gracias a la polimerasa Pwo SuperYield, la cual tiene actividad exonucleasa $3^{\prime} \rightarrow 5^{\prime}$ en ausencia de dNTP, por lo que tiene que ser incorporada en la reacción de PCR en último lugar.

El volumen final de cada reacción de PCR fue de $50 \mu \mathrm{L}$. Para ello se añadieron $5 \mu \mathrm{L}$ de PCR buffer $10 \mathrm{X}(1,5 \mathrm{mM} \mathrm{MgCl})$, 27,5 $\mu \mathrm{L}$ de agua libre de nucleasas, $200 \mu \mathrm{M}$ dNTP (PCR Grade Nucleotide Mix), $10 \mu \mathrm{L}$ de GC-RICH Resolution solution 5X (tampón para mejorar la amplificación en función del contenido de GC del ADN a amplificar), 2,5 U de polimerasa Pwo SuperYield $D N A$ y 5 pmol de cada oligonucleótido ${ }_{s s}$ (sentido y antisentido). Como control negativo en cada serie se empleó la mezcla de todos los componentes de la reacción menos los cebadores. Las reacciones de amplificación se llevaron a cabo en un termociclador de Perkin Elmer modelo 9700 (Applied Biosystems GeneAmp®, NY, EEUU). Se emplearon distintos programas de PCR, modificando el tiempo y la temperatura de anillamiento de los cebadores (figura 53).

Desnaturalización

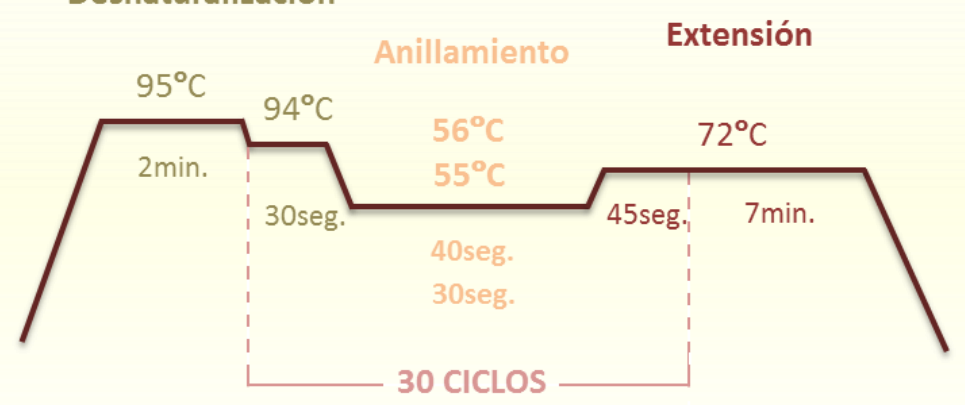

Figura 53. Programas de PCR para la concatemerización. 
Los productos de PCR fueron analizados por su tamaño molecular mediante electroforesis en geles horizontales de agarosa al 1\% en tampón TAE al 0,5X. Para su preparación se utilizó agarosa NuSieve® 3:1 Agarose (Cambrex Bio Science Rockland, Inc, EEUU), tampón TAE al 10X (Promega, Madison, WI, EEUU), compuesto por $400 \mathrm{mM}$ de Tris-acetato y $10 \mathrm{mM}$ de EDTA a pH 8,2-8,4; agua destilada para su dilución al $0,5 \mathrm{X}$ con y bromuro de etidio al $2 \%$ etidio para la visualización en el transiluminador de los fragmentos de ADN, añadiendo $5 \mu \mathrm{L}$ de por cada $100 \mathrm{~mL}$ de gel.

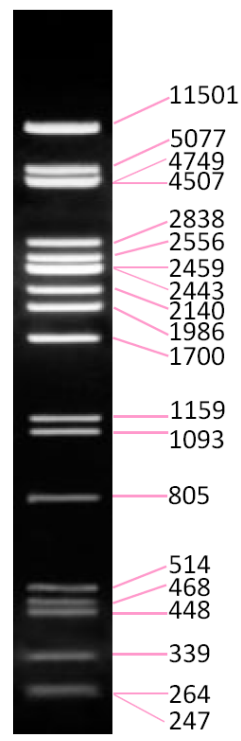

Figura 54. Marcador de peso molecular del fago $\lambda$ digerido con Pstl. Tamaño de los fragmentos de ADN generados en pares de bases, en un gel de agarosa al $0,7 \%$.

Se cargó un volumen de $5 \mu \mathrm{L}$ de cada uno de los productos de PCR previamente mezclados con $1 \mu \mathrm{L}$ de tampón de carga DNA Loading Buffer Red (Bioline) que migra en un gel de agarosa al 1\% con los fragmentos de 1500 pb. En todos los geles se cargó en el primer pocillo un marcador de peso molecular, concretamente el fago $\lambda$ digerido con la enzima de restricción Pstl (Fermentas, Thermo Fisher Scientific, MA, EEUU), cuyo patrón se muestra en la figura 54. 
Esto permitió contrastar en paralelo el tamaño del producto de PCR obtenido y estimar su calidad. El resultado de una síntesis de concatémeros correcta se visualizaba en gel de agarosa en forma de un conjunto de bandas de distintos tamaños desde 5 a $40 \mathrm{~Kb}$. Sin embargo, pese a las diferentes pruebas y modificaciones de este protocolo, no se consiguió obtener el patrón de concatemerización adecuado.

\section{SHIFT - WESTERN BLOTTINNG}

Los ensayos shift-western blotting constituyen una variante de los estudios de retardo en gel. Están basados en la detección e identificación de las proteínas de unión al ADN de los complejos ADN:proteína a partir de anticuerpos específicos frente a ellas, prescindiendo del marcaje del ADN. La combinación de la información resultante de los ensayos de retardo en gel y el análisis in silico de las variantes del promotor del gen PTGDR; -613C $>\mathrm{T},-549 \mathrm{~T}>\mathrm{C},-441 \mathrm{C}>\mathrm{T}$, 197T >C y $-95 \mathrm{G}>$ T fue utilizada para el diseño de estos estudios. La capacidad de detectar las proteínas integradas en estos complejos ADN:proteína reside igualmente en la estabilización de las uniones entre ambos, y en la especificidad y sensibilidad del anticuerpo o anticuerpos empleados frente a las proteínas concretas objeto del estudio.

Se utilizó el sistema DIG Gel Shift Kit 2nd Generation (Roche Applied Science, Mannheim, Alemania) para la reacción de unión y la electroforesis y el kit Pierce Fast Western Blot Kit, Supersignal West Pico Substrate (Thermo Fisher Scientific, MA, EEUU) para el proceso de detección de los complejos, así como una selección de tres anticuerpos primarios frente a la proteína control Oct2A y dos factores de transcripción E2F-1 y DP1, susceptibles de presentar una unión diferencial en función de los polimorfismos -613C > T y -197 T >C de PTGDR (tabla 1). 
Tabla 1. Relación de los anticuerpos empleados en los ensayos de shiftwestern blotting.

\begin{tabular}{|c|c|c|c|c|}
\hline \multicolumn{2}{|c|}{ Anticuerpo } & Origen/Isotipo & Antigeno & Casa \\
\hline \multirow{3}{*}{ Primarios } & $\begin{array}{l}\text { Anti-Oct-2 } \\
\text { Policlonal }\end{array}$ & Conejo/IgG & $\begin{array}{l}\mathrm{C}_{\text {terminal }} \text { de } \\
\text { Oct2A }\end{array}$ & \multirow{5}{*}{$\begin{array}{c}\text { Thermo } \\
\text { Fisher } \\
\text { Scientific }\end{array}$} \\
\hline & $\begin{array}{l}\text { Anti-E2F1 } \\
\text { Policlonal }\end{array}$ & Conejo/IgG & Proteína DP-1 & \\
\hline & $\begin{array}{l}\text { Anti-DP1 } \\
\text { Monoclonal }\end{array}$ & Ratón/IgG1, k & $\begin{array}{l}\text { Péptido de E2F1 } \\
\text { (aа 392-414) }\end{array}$ & \\
\hline \multirow{2}{*}{ Secundarios } & \multicolumn{2}{|c|}{$\begin{array}{c}\text { Fast Western Rabbit Optimized } \\
\text { HRP Reagent, Pico }\end{array}$} & $\begin{array}{l}\text { Fc de IgG de } \\
\text { conejo }\end{array}$ & \\
\hline & \multicolumn{2}{|c|}{$\begin{array}{c}\text { Fast Western Mouse Optimized } \\
\text { HRP Reagent, Pico }\end{array}$} & $\begin{array}{l}\text { Fc de lgG de } \\
\text { ratón }\end{array}$ & \\
\hline
\end{tabular}

El kit Pierce Fast Western Blot Kit, Supersignal West Pico Substrate se utiliza para ensayos de western blot con la mejora de los tiempos de los distintos pasos de metodología. En él se incluyen los anticuerpos secundarios conjugados con peroxidasa de rábano picante (HRP: horseradish peroxidase) y luminol como sustrato quimioluminiscente de esta enzima. Este compuesto es oxidado en presencia de peróxido de hidrogeno $\left(\mathrm{H}_{2} \mathrm{O}_{2}\right)$ para producir el 3-aminoftalato en estado excitado, el cual decae emitiendo luz, que se registra en películas de rayos $X$ o en cámaras o instrumentos que detectan esta señal (figura 55).

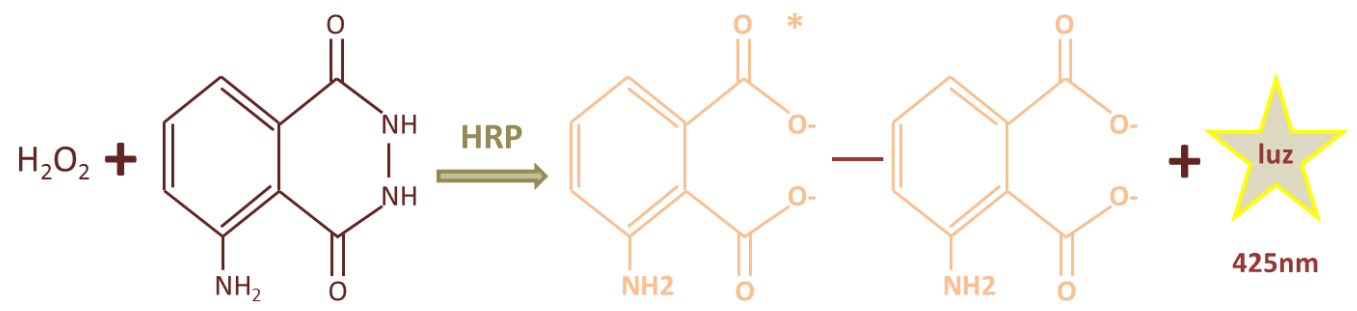

luminol

Figura 55. Reacción de oxidación del luminol por la peroxidasa HRP. 


\section{$>$ FRAGMENTOS DE ADN}

Los fragmentos de ADNds empleados fueron los mismos que los diseñados en los ensayos de retardo en gel para las variantes génicas; -613C > T y -197T>C (apéndice). Su síntesis se llevó a cabo mediante el protocolo de anillamiento previamente descrito, a partir de las parejas formadas por cada oligonucleótido y su complementario a la concentración de $100 \mu \mathrm{M}$. Una vez obtenidos los oligonucleótido $_{\mathrm{ds}}$ se almacenaron a $-20^{\circ} \mathrm{C}$. Como control positivo de estos ensayos se empleó el oligonucleótido ${ }_{\mathrm{ds}}$ sin marcar $(100 \mu \mathrm{M})$, que contenía en su secuencia el sitio de unión de la proteína Oct2A (figura 46) aportado por el DIG Gel Shift Kit.

\section{EXTRACTO PROTEICO}

Se empleó un extracto comercial de proteínas nucleares procedentes de leucocitos de sangre periférica de un adulto normal (AMS Biotechnology, Osfordshire, Reino Unido). La concentración de las mismas era de $1 \mathrm{mg} / \mathrm{ml}$ y el tampón que las contenía incluía HEPES (pH 7,9), glicerol, $\mathrm{NaCl}, \mathrm{MgCl}_{2}$, EDTA y un conjunto de inhibidores de proteasas.

Para el ensayo control se utilizó la proteína Oct2A del DIG Gel Shift Kit a una concentración de 25-75 ng/ $\mathrm{LL}$. Oct2A reconoce específicamente la secuencia del oligonucleótido control del mismo kit.

\section{$>$ REACCiÓN DE VNi@́N}

Las condiciones de la reacción de unión entre las proteínas y el ADN fueron idénticas a las de los ensayos de retardo en gel, empleando poli-L-lisina para la optimización de la formación de complejos ADN:proteína específicos y poli [d(I$C)]$ o poli $[d(A-T)]$ como competidores inespecíficos de las uniones entre el ADN y las proteínas. Lo que no fue necesario en los estudios de shift-western fue el 
competidor específico, puesto que a partir de los ensayos de retardo en gel ya se estableció la especificidad de los complejos ADN:proteína. Cada ensayo de shiftwestern blotting se realizó únicamente con el oligonucleótido ${ }_{\mathrm{ds}}$ sin marcar y el extracto proteico.

Se preparó un tubo eppendorf debidamente identificado para cada reacción de unión. El tampón contenía HEPES a $20 \mathrm{mM}(\mathrm{pH} 7,6)$, EDTA a $1 \mathrm{mM}$, $\left(\mathrm{NH}_{4}\right)_{2} \mathrm{SO}_{4}$ a $10 \mathrm{mM}$, DTT a $1 \mathrm{mM}$, Tween 20 al 0,2\% (peso/volumen), $\mathrm{KCl}$ a 30 $\mathrm{mM}$, poli $[\mathrm{d}(\mathrm{I}-\mathrm{C})]$ a $0,05 \mu \mathrm{g} / \mu \mathrm{L}$, y poli L-lisina a $0,005 \mu \mathrm{g} / \mu \mathrm{L}$ en un volumen final de $20 \mu \mathrm{L}$. Se añadieron $200 \mu$ moles de oligonucleótidos $\mathrm{ds}_{\mathrm{y}} \mathrm{y}$ del oligonucleótido control y, como último componente, se añadieron $5 \mu \mathrm{g}$ del extracto de proteínas nucleares y $2 \mu \mathrm{L}$ de la solución de proteína control Oct2A. Las reacciones de unión fueron mezcladas brevemente mediante vortex y un pulso de centrífuga e incubadas durante 30 minutos a temperatura ambiente $\left(25^{\circ} \mathrm{C}\right)$ y posteriormente colocadas en hielo antes de ser aplicadas en el gel de poliacrilamida.

\section{ELECTR@FORESÍS EN GEL DE POLİACRÍLAMÍDA}

Los complejos ADN:proteína fueron separados mediante electroforesis en condiciones no desnaturalizantes en geles de poliacrilamida al 8\% y tampón TBE al 0,5X. Su preparación se realizó siguiendo el protocolo previamente descrito en los ensayos de retardo en gel. Una vez polimerizado el gel y pre-corrido en TBE al $0,5 \mathrm{X}$ a $200 \mathrm{~V}$ y $4 \stackrel{\circ}{\circ}$ durante 2 horas se aplicaron en sus pocillos las muestras previamente mezcladas con $5 \mu \mathrm{L}$ de tampón de carga Loading buffer con azul de bromofenol $(0,25 X$ TBE, $60 \%$ glicerol) y se sometió a una corriente eléctrica de 200 V durante 120 minutos a $4^{\circ} \mathrm{C}$. 


\section{ELECTROTRANSFERENCIA}

La electrotransferencia de las proteínas desde el gel de poliacrilamida a la membrana de nitrocelulosa de $0,45 \mu \mathrm{m}$ de poro (Amersham Hybond ${ }^{\mathrm{TM}} \mathrm{ECL}^{\mathrm{TM}}$,

GE Healthcare, Oslo, Noruega), se realizó utilizando el sistema PowerPac ${ }^{\mathrm{TM}}$ Basic (Bio-Rad, California, EEUU) en tampón de transferencia (386 mM glicina; $0,1 \%$ SDS; $20 \%$ metanol y $66 \mathrm{mM}$ Tris $\mathrm{pH} 8,5)$. Las membranas de nitrocelulosa unen y retienen a las proteínas en su matriz, dependiendo principalmente de interacciones hidrofóbicas y de enlaces por puente de hidrógeno entre los aminoácidos de las proteínas y los grupos nitro $\left(\mathrm{NO}_{2}\right)$ de la membrana [220].

La membrana de nitrocelulosa fue humedecida durante 5 minutos en el tampón de transferencia antes de ser puesta en contacto con el gel, así como las hojas de papel Whatman 3MM y las almohadillas. La electrotransferencia se realizó a $4^{\circ} \mathrm{C}$ y $35 \mathrm{~V}$ durante 12 horas.

\section{INM VNODETECCIÓN ESPECIFICA DE PROTEINAS}

Para la detección de las proteínas de unión al ADN se emplearon dos kits Pierce Fast Western Blot Kit, Supersignal West Pico Substrate (Thermo Fisher Scientific, MA, EEUU) que contienen las soluciones de bloqueo y de lavado, los anticuerpos secundarios anti-lgG de conejo y anti-lgG de ratón respectivamente conjugados con peroxidasa, y el sustrato luminiscente para la reacción enzimática.

Una vez hibridadas y fijadas las proteínas en la membrana de nitrocelulosa, está se incubó durante 5 minutos con solución de lavado (dilución del Fast Western 10x Wash Buffer al 1x con agua destilada) para eliminar el tampón de transferencia residual. A continuación, se incubó cada membrana con los anticuerpos primarios (tabla 1) diluidos a $1 \mu \mathrm{g} / \mathrm{ml}$ en solución de bloqueo (Fast 
Western Antibody Diluent); a $4^{\circ} \mathrm{C}$ durante 12 horas y en agitación suave. Posteriormente se eliminó la solución del anticuerpo primario y se añadió la solución del o de los anticuerpos secundarios (Fast Western Mouse Optimized HRP Reagent, Pico o Fast Western Rabbit Optimized HRP Reagent, Pico) diluidos al 1:10 en solución de bloqueo (Fast Western Antibody Diluent), en la cual se incubó la membrana a temperatura ambiente y en agitación durante 20 minutos. Posteriormente se realizaron 2 lavados de 10 minutos cada uno con $20 \mathrm{~mL}$ de solución de lavado con objeto de eliminar el exceso de anticuerpo unido inespecíficamente. Por último, la membrana se incubó a temperatura ambiente durante 5 minutos y en agitación con la solución de detección (solución al 1:1 de Supersignal West Pico Luminol/Enhacer Solution y Supersignal West Stable Peroxidase Solution) preparada inmediatamente antes de la incubación. Finalmente la membrana se envolvió en un plástico transparente eliminando el exceso de solución de detección y las burbujas de aire y se expuso a una película autorradiográfica de alta sensibilidad (Kodak) cuyo revelado se llevó a cabo con los reactivos Kodak® processing chemicals for autoradiography films (Sigma-Aldrich Co. LLC, EEUU).

\section{ELECTROFORESISS DE PROTEINAS Y WESTERN BLOTTINNG}

Se realizó el análisis del extracto comercial de proteínas nucleares procedentes de leucocitos de sangre periférica de un adulto normal (AMS Biotechnology, Osfordshire, Reino Unido) mediante electroforesis en condiciones desnaturalizantes y western blotting. Como control de este ensayo se empleó la proteína Oct2A purificada contenida en el kit DIG Gel Shift Kit 2nd Generation (Roche Applied Science, Mannheim, Alemania). 


\section{ELECTROFORESÍS DE PROTEÍNAS EN SDS-PAGE}

La electroforesis en presencia de SDS se realizó en geles de poliacrilamida (SDS-PAGE: SDS-polyacrilamide gel electrophoresis), según el método descrito por Laemmli [226]. Se utilizaron minigeles discontinuos de 1,5 mm de espesor y $10 \mathrm{~cm}$ de anchura, siendo la longitud aproximada del gel separador de 4,5-5 cm y de $1,5 \mathrm{~cm}$ la del gel empaquetador.

El gel separador se preparó al 10\% de acrilamida/bisacrilamida (concentración inicial del 30\%) y SDS. El gel empaquetador se preparó al 4\% acrilamida/bisacrilamida y con SDS. Para la polimerización de los geles se añadieron AMPS al 10\% y TEMED.

Las muestras de proteína se prepararon añadiendo tampón de carga SPLB al 6X (60 mM de Tris/HCl 1M pH 6,8; Glicerol al 25\%; SDS al 2\%; 14,4 mM de 2mercaptoetanol y azul de bromofenol al $0,1 \%$ ) en la cantidad necesaria para que éste quedara al $1 \mathrm{X}$ en dicha mezcla. Cada muestra fue desnaturalizada durante 10 minutos a $100^{\circ} \mathrm{C}$ antes de ser cargada en el gel de poliacrilamida y sometida a electroforesis durante aproximadamente 1 hora y media a 150-180 V; tiempo aproximado en el cual el frente de proteínas alcanzaba el final del gel. El tampón de electroforesis en el que se mantuvo siempre sumergido el gel estaba compuesto por $25 \mathrm{mM}$ Tris- $\mathrm{HCl} \mathrm{pH} 8,3 ; 250 \mathrm{mM}$ glicina y $0,1 \%$ SDS.

En paralelo se cargaron $10 \mu \mathrm{L}$ de marcador de peso molecular PageRuler ${ }^{\mathrm{TM}}$ Prestainer protein ladder plus (Fermentas, Thermo Fisher Scientific, MA, EEUU) que sirvió de indicador del tamaño de las bandas que se observaron tras el revelado (figura 56). 


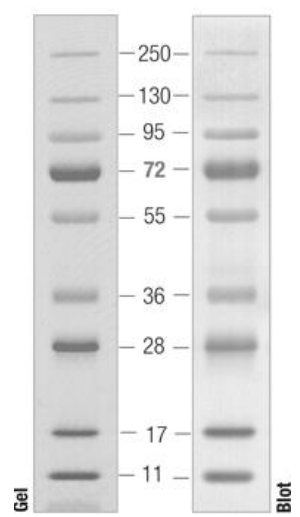

Figura 56. Marcador de peso molecular para electroforesis de proteínas. Tamaños expresados en Kilodaltons (KDa).

\section{ELECTROTRANSFERENCIAA DE PROTEÍNAS}

La electrotransferencia de proteínas desde geles de poliacrilamida a membranas de PVDF Amersham Hybond ${ }^{\mathrm{TM}}$ (polyvinylidene difluoride) de 0,45 $\mu \mathrm{m}$ de poro, se realizó utilizando el sistema de transferencia húmeda de Bio-Rad en tampón de transferencia (386 mM glicina; 0,1\% SDS; 20\% metanol y $66 \mathrm{mM}$ Tris $\mathrm{pH}$ 8,5). Las membranas fueron previamente activadas durante unos segundos con metanol, hidratadas con agua destilada y humedecidas en tampón de transferencia antes de ser puestas en contacto con el gel. La electrotransferencia se realizó siempre en frío durante 2 horas a $100 \mathrm{~V}$.

\section{$>$ TíNCÍ́N DE PR@TEÍNAS EN GELES DE POLIACRÍLAMİDA}

Para verificar la eficiencia de la transferencia, las membranas fueron teñidas de manera reversible con solución Ponceau S (Sigma-Aldrich Co. LLC, EEUU) durante 5 minutos a temperatura ambiente y en agitación continua. Posteriormente, se lavaron las membranas en agua destilada durante 2 minutos y se confirmó la tinción en color rojo del patrón de bandas correspondiente a las muestras bien transferidas. Para desteñir completamente las membranas se 
lavaron con TBS-Tween (150 mM NaCl; $10 \mathrm{mM}$ Tris pH 7,3; 0,1\% Tween-20 (Bio-Rad)).

\section{$>$ INMVNODETECCIÓN ESPECÍFICA DE PROTEÍNAS}

Para la detección de las proteínas de unión al ADN se emplearon los dos kits Pierce Fast Western Blot Kit, Supersignal West Pico Substrate (Thermo Fisher Scientific, MA, EEUU) empleados en los ensayos de shift-western blotting y; del mismo modo se continuó con el protocolo descrito anteriormente. Los anticuerpos primarios y secundarios empleados son los recogidos en la tabla 1.

\section{AIISLAMIENTO EN GEL DEL COMPLEJO ADN: PROTEÍNA}

El aislamiento de los complejos ADN:proteína identificados en los ensayos de retardo en gel se llevó a cabo reproduciendo las condiciones de unión entre ADN y proteínas, y recortando las bandas en el gel de acrilamida con el fin de purificar a partir de ellas con distintas metodologías el componente proteico. Para ello se diseñaron los experimentos de aislamiento utilizando un gel de poliacrilamida para las dos reacciones de unión de cada polimorfismo del promotor de PTGDR, inicialmente $-613 \mathrm{C}>\mathrm{T}$ y $-197 \mathrm{~T}>\mathrm{C}$. Una de las reacciones se realizó con el fragmento de la región conservada y la otra con el fragmento que contenía la variante. En cada gel se empleaban cuatro de sus pocillos, con las dos reacciones de unión colocadas por duplicado de manera que la mitad del gel resultara la imagen especular de la otra mitad respecto a su contenido (figura 57). Una de las mitades del gel se transfería y se revelaba para ser utilizada como guía en el recorte de la otra mitad. No fueron necesarios los estudios de especificidad de los complejos, ni los controles positivo ni negativo de este ensayo, ya que se disponía de estos datos, fruto de los ensayos de retardo previos. Por tanto, en estos ensayos de aislamiento se emplearon el sistema DIG 
Gel Shift Kit 2nd Generation y el kit DIG Wash and Block Buffer Set (Roche Applied Science, Manheim, Alemania).

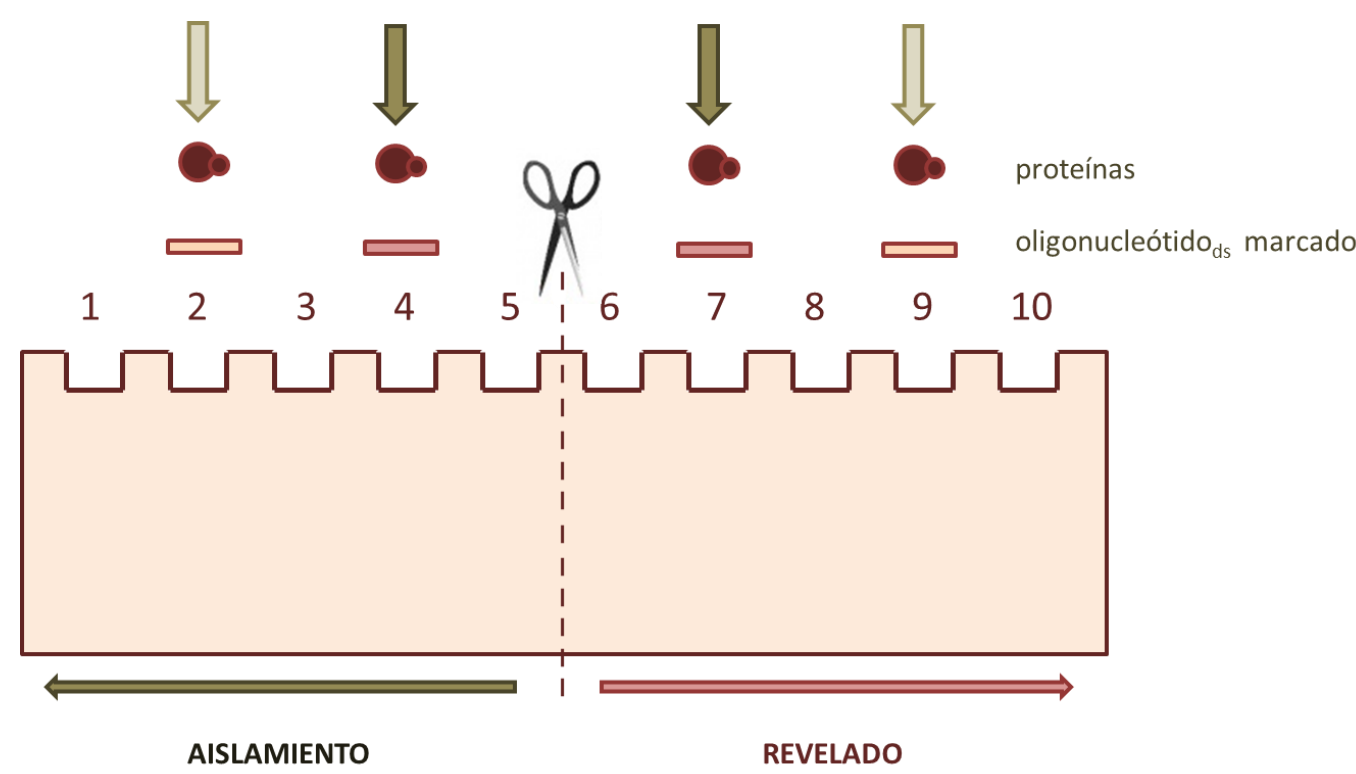

Figura 57. Esquema del contenido de un gel de electroforesis para el aislamiento de los complejos ADN:proteína basado en los ensayos de retardo en gel.

Los fragmentos de ADNds empleados fueron los mismos que los diseñados en los ensayos de retardo en gel para las variantes génicas; -613C>T y -197T>C (apéndice). Igualmente a partir de la pareja de oligonucleótidos $s_{s s}$ a una concentración de $4 \mu \mathrm{M}$ se procedió al anillamiento, etiquetado y purificación de los mismos, así como la detección de la eficacia de marcaje, siguiendo los protocolos anteriormente descritos para los estudios de retardo en gel, sin incluir en ellos el control positivo. Se empleó el extracto comercial de proteínas nucleares procedentes de leucocitos de sangre periférica de un adulto normal (AMS Biotechnology, Osfordshire, Reino Unido). 


\section{$>$ REACCIீ́N DE VNi@́N}

Las condiciones de la reacción de unión entre las proteínas y el ADN fueron idénticas a las de los ensayos de retardo en gel, empleando poli-L-lisina para la optimización de la formación de complejos ADN:proteína específicos y poli [d(IC)] o poli $[d(A-T)]$ como competidores inespecíficos de las uniones entre el $A D N$ y las proteínas; sin embargo no fue necesario el competidor específico. Se preparó un tubo eppendorf debidamente identificado para cada reacción de unión. El tampón contenía HEPES a $20 \mathrm{mM}\left(\mathrm{pH}\right.$ 7,6), EDTA a $1 \mathrm{mM},\left(\mathrm{NH}_{4}\right)_{2} \mathrm{SO}_{4}$ a $10 \mathrm{mM}$, DTT a $1 \mathrm{mM}$, Tween 20 al 0,2\% (peso/volumen), $\mathrm{KCl}$ a $30 \mathrm{mM}$, poli [d(IC)] a $0,05 \mu \mathrm{g} / \mu \mathrm{L}$, y poli L-lisina a $0,005 \mu \mathrm{g} / \mu \mathrm{L}$ en un volumen final de $20 \mu \mathrm{L}$. Se

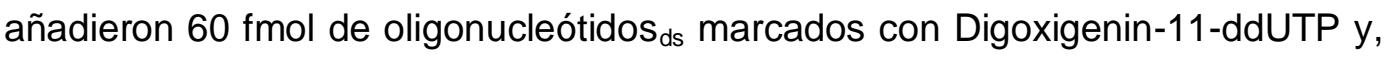
como último componente, $2 \mu \mathrm{g}$ del extracto de proteínas nucleares. Las reacciones de unión fueron mezcladas brevemente mediante vortex y un pulso de centrífuga, incubadas durante 30 minutos a temperatura ambiente $\left(25^{\circ} \mathrm{C}\right)$ y posteriormente colocadas en hielo antes de ser aplicadas en el gel de electroforesis.

\section{$>$ ELECTROFORESISS EN GEL DE POLIACRILAMİDA}

Los complejos ADN:proteína fueron separados mediante electroforesis en condiciones no desnaturalizantes en geles de poliacrilamida al 8\% y tampón TBE al $0,5 \mathrm{X}$ siguiendo el mismo procedimiento para su preparación que en los ensayos de retardo en gel. Una vez polimerizados y pre-corridos en TBE al 0,5X a $200 \mathrm{~V}$ y $4^{\circ} \mathrm{C}$ durante 2 horas, se aplicaron en los pocillos del gel las muestras previamente mezcladas con $5 \mu \mathrm{L}$ de Loading buffer con azul de bromofenol $(0,25 X$ TBE, $60 \%$ glicerol $)$. Se e sometieron entonces a una corriente eléctrica de $200 \mathrm{~V}$ durante 100 minutos a $4^{\circ} \mathrm{C}$. Pasado este tiempo, los geles fueron retirados de los cristales y cortados por la mitad, manteniendo la primera en agua, 
mientras se continuaba con la transferencia a membrana y revelado de la segunda.

La electrotransferencia a membranas de nylon positivamente cargadas de 0,45 $\mu \mathrm{m}$ de poro (Roche Applied Science, Manheim, Alemania) se realizó utilizando un sistema de transferencia húmeda (PowerPac ${ }^{\mathrm{TM}}$ Basic Bio-Rad, California, EEUU) y TBE al 0,5X como tampón de transferencia, siguiendo el procedimiento indicado anteriormente en los ensayos de retardo en gel para este paso. La electrotransferencia se realizó a $4^{\circ} \mathrm{C}$ y 400 miliamperios durante 30 minutos. Del mismo modo, después de la fijación de los ácidos nucleicos a las membranas aplicando $120 \mathrm{~mJ}$ en el crosslinker BIO-LINK® BLX-E254 (Vilber Lourmat, Cedex, Francia), se procedió al revelado y detección de los fragmentos marcados por quimioluminiscencia siguiendo las indicaciones del protocolo previamente descrito para la detección de los oligonucleótidos marcados con digoxigenina por los sistemas DIG Gel Shift Kit 2nd Generation; y el kit DIG Wash and Block Buffer Set (Roche Applied Science, Mannheim, Alemania).

Una vez obtenida la película autorradiográfica con las señales correspondientes, ésta se hizo coincidir cuidadosamente con la mitad del gel, se recortaron las bandas y se almacenaron en un tubo eppendorf a $4^{\circ} \mathrm{C}$.

\section{IDENTIIFCACIÓN DE PROTEÍNAS POR MALDI-TOF/TOF}

El análisis de las proteínas de unión a los fragmentos de ADN en torno a las posiciones $-613 \mathrm{C}>\mathrm{T}$ y $-197 \mathrm{~T}>\mathrm{C}$ del promotor de $\mathrm{PTGDR}$ se realizaron en la Unidad de Proteómica de la Universidad Complutense de Madrid (UCM-PCM) perteneciente al Instituto Nacional de Proteómica, ProteoRed mediante espectrometría de masas MALDI-TOF/TOF. Esta metodología consiste en la digestión enzimática de una proteína y en la adquisición del correspondiente 
espectro de masas de los péptidos resultantes y su comparación con un espectro teórico. La digestión enzimática de las proteínas produce un conjunto de péptidos con masas moleculares características para la proteína digerida, y en este sentido, el espectro de masas de este conjunto de péptidos se cataloga como una huella de la proteína, lo que se conoce como PMF (Peptide Mass Fingerprint) [227].

\section{PREPARACIÓN DE LAS MVESTRAS}

\section{DIGESTIION CON TRAPSINA}

Las proteínas seleccionadas para el análisis fueron digeridas en gel con tripsina y sus péptidos posteriormente extraídos siguiendo los protocolos de Shevchenko [228]. Los fragmentos de gel se lavaron 2 veces con agua, se disolvieron en acetonitrilo al 100\% (v/v) durante 15 minutos y se secaron en un Savant SpeedVac en 30 minutos. Después, las muestras fueron rehidratadas en una solución que contenía $10 \mathrm{mM}$ de DTT y $25 \mathrm{mM}$ de bicarbotano amónico durante 30 minutos a $56^{\circ} \mathrm{C}$; para posteriormente ser incubadas en una solución $55 \mathrm{mM}$ de iodoacetamida y $25 \mathrm{mM}$ de bicarbotano amónico durante 15 minutos y en oscuridad. Finalmente, las muestras fueron digeridas con tripsina (sequencing grade trypsin, Roche Molecular Biochemicals) a una concentración de 12,5 ng/ $\mu \mathrm{L}$ en $25 \mathrm{mM}$ de bicarbotano amónico $(\mathrm{pH} 8,5)$ durante 12 horas y a 37ํㅡ.

\section{ANÁLiSíS MEDİANTE MALDI-TOF/TOF}

Una vez digeridas las muestras, se recuperaron los sobrenadantes de las mismas y se colocó un volumen de $1 \mu \mathrm{L}$ de cada uno de ellos en una placa MALDI donde los péptidos extraídos fueron deshidratados a temperatura ambiente. Posteriormente se añadió la matriz para MALDI compuesta por $3 \mathrm{mg} / \mathrm{ml}$ de ácido a-ciano-4-hidroxi-transcinámico (Sigma) en acetonitrilo al 50\% 
y se dejaron secar de nuevo a temperatura ambiente hasta que la mezcla de péptidos y matriz adquirió una apariencia cristalina. La matriz empleada depende de la naturaleza de los analitos, en este caso péptidos, para los cuales la matriz de elección es la citada anteriormente.

Los análisis MALDI-TOF MS se llevaron a cabo en un espectrómetro de masas 4800 MALDI-TOF/TOF Proteomics Analyzer (Applied Biosystems, Framingham, MA, EEUU). El sistema operó en modo reflectrón positivo con un voltaje de aceleración de 20000 V. Todos los espectros de masas fueron calibrados internamente con los péptidos de la autodigestión de la tripsina.

El análisis de proteínas con espectrometría de masas MALDI TOF/TOF generó amplios listados de masas (masa/carga), entre los cuales aquellos con un umbral de fondo de 20 (relación señal/ruido) pudieron ser cotejados y representados en una lista de masas monoisotópicas. Posteriormente se seleccionaron iones intensos no fragmentados en modo automático y se obtuvo del espectro de MS/MS utilizando una energía de colisión de 1 kV y aire como gas de colisión. El modo de trabajo y la calibración de los espectros fueron optimizados para el procesamiento de los espectros MS/MS.

\section{IDENTIIFICACIÓN DE PROTEÍNAS}

Para la identificación se ha utilizado el programa MASCOT 2.1 (matrixscience.com), que emplea un algoritmo de búsqueda denominado MOWSE para la comparación de los listados de masas obtenidos con MALDITOF con las masas de péptidos de digestiones teóricas de proteínas recogidas en las bases de datos NCBI o SwissProt. El programa genera una lista ordenada según la probabilidad de correspondencia con las proteínas analizadas. Los parámetros de búsqueda fueron los siguientes: 
- Carbamidometil cisteína como modificación fija debido al tratamiento con yodoacetamida, y metioninas oxidadas como modificación variable.

- Tolerancia de masa peptídica de 50 ppm para las huellas peptídicas o PMF (Peptide Mass Fingerprint) y 100 ppm para los espectros de MS-MS.

- Tolerancia de hasta un sitio de ruptura tríptica sin digerir.

- Tolerancia de fragmentos MS/MS de 0,3 Da.

En todas las identificaciones proteicas, la probabilidad de puntuaciones fue superior a la mínima puntuación establecida como significativa con un valor-p menor de 0,05 .

\subsection{ESTVDiO ESTADÍSTICO DE ASOCíACí́N GÉNiCA}

\section{ANÁLiSíS DESCRİPTíV@}

El análisis descriptivo de la población estudiada se llevó a cabo utilizando el paquete estadístico SPSS 15.0 (IBM, Chicago, Illinois, EEUU). El análisis de variables cualitativas se realizó a través de medidas de tendencia central como la media o mediana, según las características de la variable y las medidas de dispersión cómo la desviación estándar. Por su parte, las variables cualitativas fueron descritas en forma de proporciones en los diferentes grupos.

\section{ANÁLíSíS BíVARíANTE Y MVLTíVARíANTE}

Se llevó a cabo un análisis estadístico comparando la distribución de los diferentes polimorfismos entre el grupo de controles y los distintos grupos de pacientes en función de sus características clínicas, con el fin de determinar una 
posible asociación entre ellos. Las diferencias se establecieron a partir de un nivel de significación de $p$-Fisher $<0,05$. Las asociaciones significativas se confirmaron a través de una regresión logística binaria ajustando por edad y sexo, con el fin de descartar la posible influencia de estas variables en la asociación; todo ello utilizando el paquete estadístico SPSS 15.0 (IBM, Chicago, Illinois, EEUU). Para estimar el riesgo derivado de las diferencias significativas se calculó el Odds Ratio (OR) con intervalo de confianza al 95\%. Además se calculó el poder estadístico de la asociación encontrada en relación al tamaño muestral, utilizando la plataforma on-line http://statpages.org/proppowr.html basada en Statistical Methods for Rates and Proportions por Joseph L. Fleiss. En los casos significativos, se determinó la probabilidad de obtener un resultado falso positivo (FPRP) utilizando el programa Wachola, según el método descrito por Wacholder y colaboradores [229].

\section{COMPARACÍÓN DE FRECVENCİAS ALÉLICAS Y GENOTÍPICAS}

Con el objetivo de estudiar posibles diferencias en la distribución de las frecuencias alélicas y genotípicas entre los controles y los distintos grupos de pacientes, se realizó la comparación de dichas frecuencias mediante un test de contingencia tipo $\chi^{2}$ utilizando la plataforma estadística on-line SHEsis [230] (http://analysis.bio-x.cn/myAnalysis.php). Se determinó la situación de equilibrio

poblacional mediante una prueba $\chi^{2}$ para el cálculo del equilibrio de HardyWeimberg. 


\section{ANÁLiSİS DE HAPLOTi̊POS Y DİPLOTİPOS}

En este estudio se ha determinado la asociación de los haplotipos y diplotipos de los polimorfismos del gen PTGDR; -613C > T, $-549 \mathrm{~T}>\mathrm{C},-441 \mathrm{C}>\mathrm{T}$, $-197 T>C$ y $-95 G>T$; respecto de las diferentes características clínicas de los pacientes. Para ello se han utilizado las siguientes herramientas estadísticas:

- Plataforma estadística on-line SHEsis (http://analysis.biox.cn/myAnalysis.php): En la comparación entre controles y pacientes de las frecuencias de los diferentes haplotipos [231].

- SNP analyzer (http://www.istech.info/istech/board/login_form.josp): Para deducir diplotipos teóricos según los algoritmos Clark, EM y el Pseudo Gibbs Sampler algorithm (PGS) con el fin de comparar la bondad de la estimación con respecto a los diplotipos reales.

- SPSS 15.0 (IBM, Chicago, Illinois, EEUU): En el estudio de la posible influencia de la presencia de un diplotipo determinado en la patología y para determinar el modelo de herencia, dominante o recesiva, de la presencia de un determinado haplotipo respecto de una característica clínico-biológica. 


\section{RESVLTADOS}

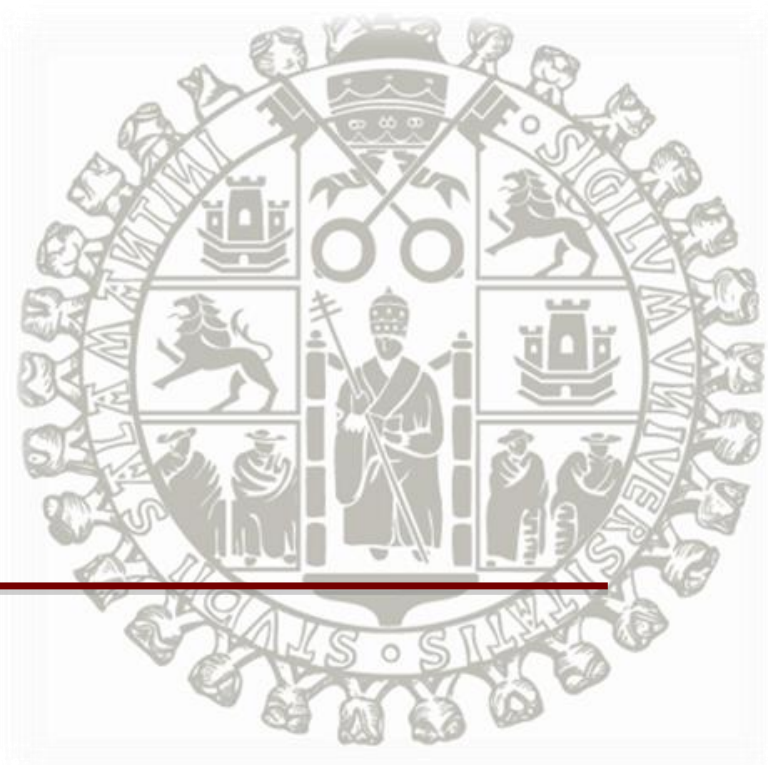





\section{RESVITADOS}

\subsection{ESTVDIO ESTADÍSTíCO DE ASOCIAACIÓN GÉNiCA}

En este trabajo se han estudiado un total de 131 variables en un grupo de 675 individuos, lo que supone un conjunto de 88.425 datos analizados.

\section{ESTADÍSTICA DESCRIPPTIVA}

\section{GR VPO CONTROL}

La población control está constituida por 250 individuos caracterizados, tras su evaluación clínica, por parte del equipo de facultativos del Servicio de Inmunoalergia del Complejo Asistencial Universitario de Salamanca siguiendo los criterios descritos previamente. Ninguno de ellos presentó síntomas de enfermedades alérgicas o respiratorias, ni tampoco antecedentes familiares de las mismas. La mediana obtenida de los niveles de $\lg E$ en suero de estos individuos fue de 35,6 kU/L (R.I.=69,85).

La proporción entre sexos estuvo desplazada hacia el sexo femenino que supuso el $60,8 \%$ de los controles frente al $39,2 \%$ correspondiente al sexo masculino (figura 58). La mediana de edad de la población control fue de 50 años (R.I.=32) (figura 59). 


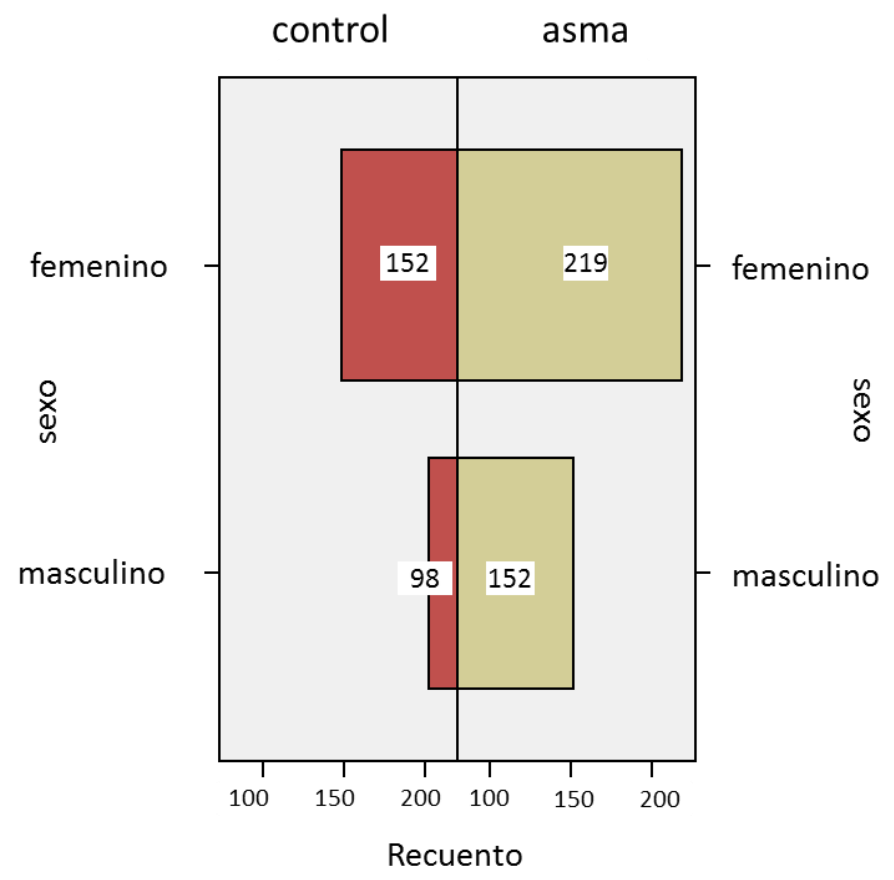

Figura 58. Distribución por sexo de la población control y el grupo de pacientes con asma.

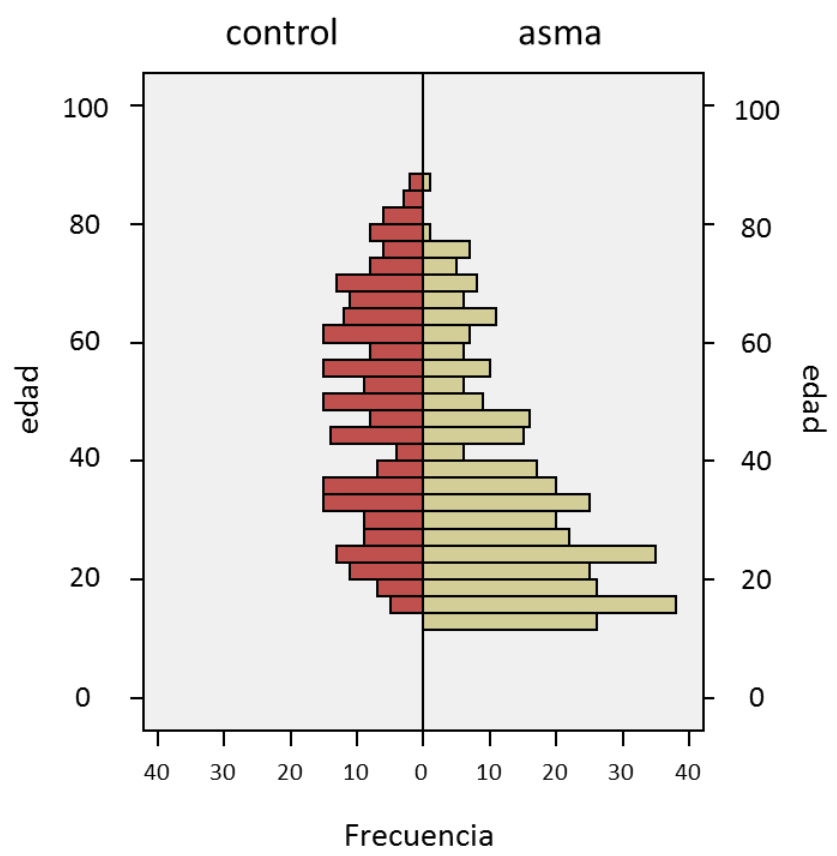

Figura 59. Distribución por edades de la población control y el grupo de pacientes con asma. 


\section{PACIENTES CON ASMA}

\section{$>$ CARACERISTICAS DEMOGRAFICAS}

En este trabajo se han estudiado un total de 371 pacientes con diagnóstico clínico de asma, todos ellos mayores de 14 años. La mediana de edad de este grupo fue de 30 años $($ R.I.= 26) (figura 59), con predominio del sexo femenino (59\%) (figura 58), al igual que en el caso del grupo control.

\section{ANTECEDENTES PERSONALES}

\section{GRAVEDAD DEL ASMA}

La gravedad del asma se valoró según las categorías establecidas por la GINA (figura 60).
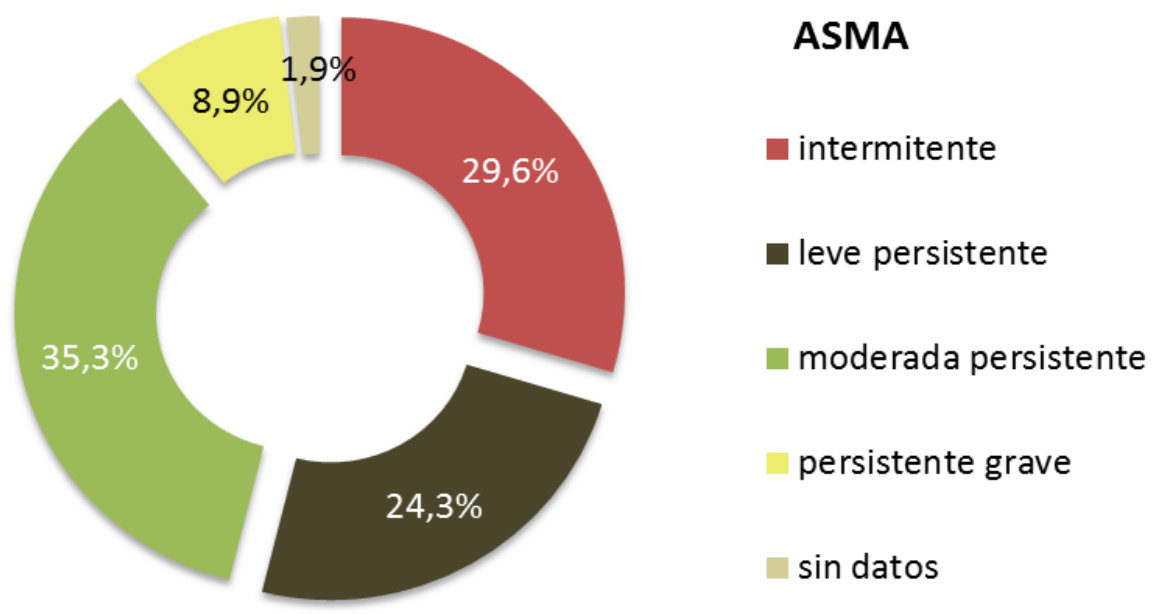

Figura 60. Gravedad del asma en los pacientes. 


\section{PRESENCIA DE ALERGIIA}

La positividad en las pruebas cutáneas frente a algún aeroalérgeno de la batería utilizada en el estudio fue del 78,6\% (334) en el total de los pacientes (figura 61). En este trabajo el conjunto de pacientes con asma y pruebas cutáneas positivas, denominados pacientes con asma alérgica ha supuesto el $65,9 \%$ del total (280). Además se ha incluido un grupo de 54 pacientes con pruebas cutáneas positivas pero que no padecían asma (12,7\%) (figura 62).

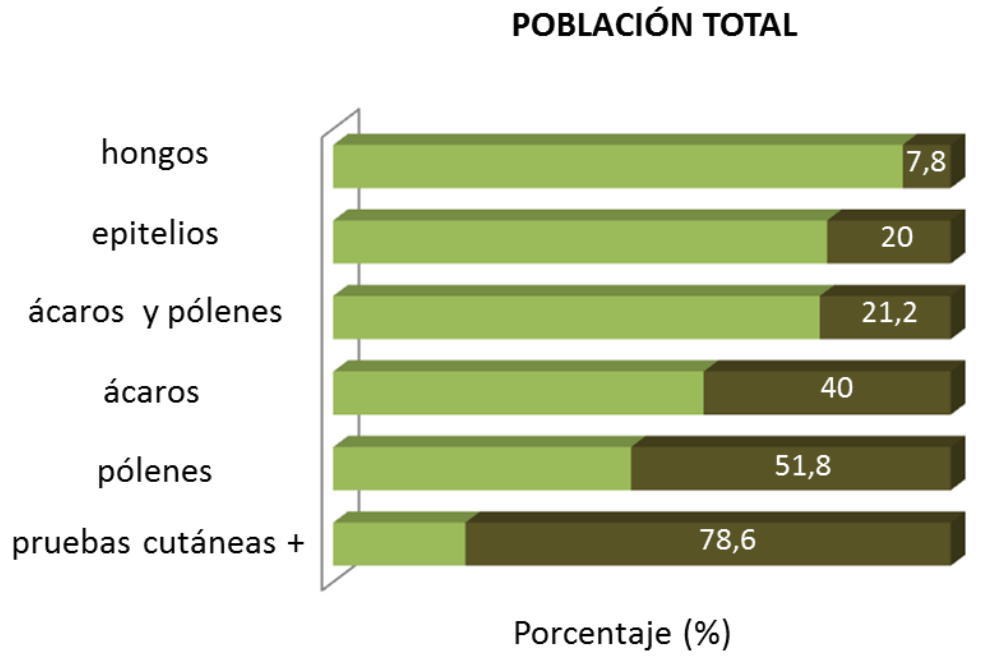

Figura 61. Pruebas cutáneas en el grupo completo de pacientes. Se representan los porcentajes de pacientes con pruebas cutáneas positivas para cada uno de los aeroalérgenos, incluyendo aquellos individuos sin patología asmática (verde oscuro).

El conjunto de pruebas cutáneas positivas se representa considerando la presencia o no de asma en las figuras 61 y 62 . A partir de la sensibilidad a ácaros y pólenes se creó una variable de sensibilidad conjunta a ambos debido a la frecuencia con la que se produce esta situación y con el fin de analizarla. Dicha variable recoge aquellos pacientes en que se producen ambas sensibilidades a la vez. 
Por otro lado, en el grupo de individuos con asma alérgica se describe una frecuencia de pacientes polisensibilizados del $41,8 \%$, entre los cuales se encuentras aquellos sensibilizados frente a dos $(28,6 \%)$, tres $(11,4 \%)$ y cuatro aeroalérgenos (1,8\%) (figura 62$)$.

La mediana de los niveles séricos de lgE de los pacientes con asma fue 188 $\mathrm{kU} / \mathrm{L}(\mathrm{R} . \mathrm{I} .=381,95)$. Entre el grupo de asma alérgica fue de $223,5 \mathrm{kU} / \mathrm{L}$ (R.I.= 466,25), y de 73,3 kU/L (R.I.= 198,20), en aquellos con asma no alérgica.

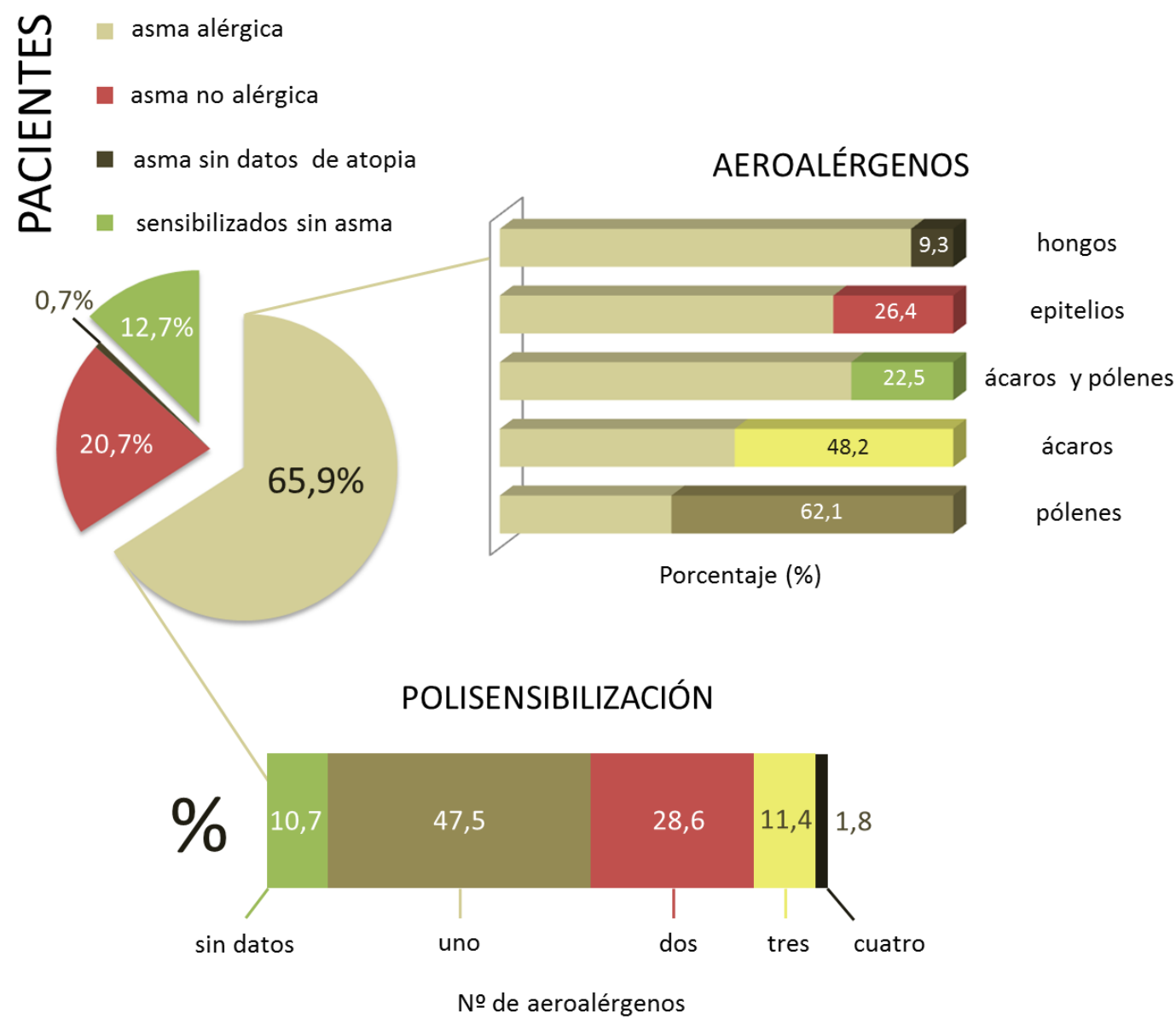

Figura 62. Pruebas cutáneas en el grupo de pacientes con asma alérgica. Se representan los porcentajes de positividad en las pruebas cutáneas para cada uno de los aeroalérgenos en el grupo de pacientes con asma alérgica (AEROALÉRGENOS); así como los porcentajes de positividad en dichas pruebas cutáneas frente a uno, dos, tres 0 cuatro de los grupos de areoalérgenos estudiados (POLISENSIBILIZACIÓN). 


\section{OTROS DATOS CLINNICOS}

De los 371 pacientes de asma el 16,7\% presentaba poliposis; un 12,4\% mostró intolerancia a los antiinflamatorios no esteroideos (AINE) y tan sólo un $6,7 \%$ sufría las tres afecciones a la vez; asma, poliposis e intolerancia a los AINE conocida como la tríada de la aspirina (figura 63).

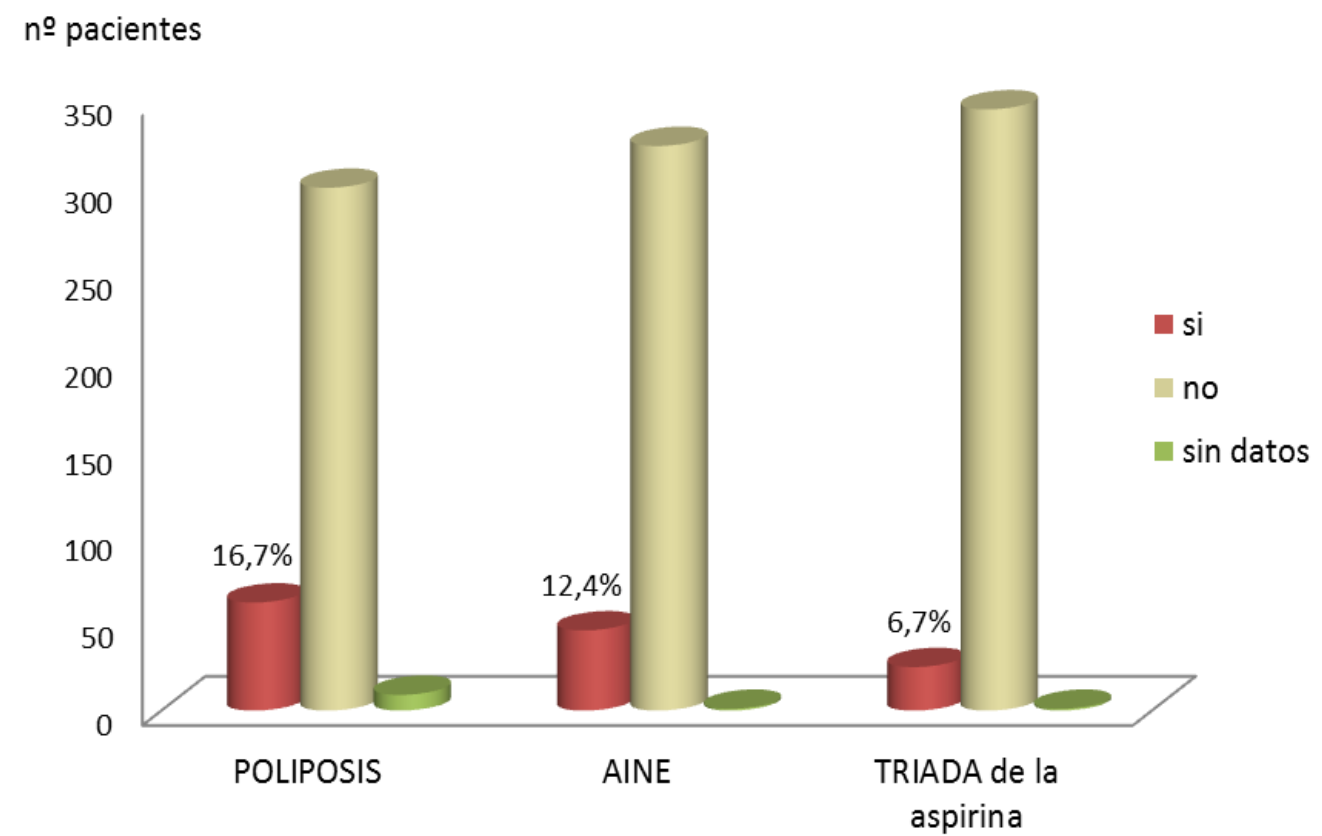

Figura 63. Prevalencia de otros datos clínicos asociados a la presencia de asma. En el eje de ordenadas se representa el número de pacientes con asma.

\section{ANTECEDENTES FAMIILIARES}

Se recogieron tanto los antecedentes familiares de asma o atopia como los antecedentes maternos. En la figura 64 se representa la distribución de los mismos en las poblaciones de pacientes con asma alérgica y asma no alérgica. Entre los pacientes afectados de asma alérgica se registraron antecedentes familiares de primer grado de asma y atopia en el $45 \%$ de los casos 
aproximadamente; mientras que en aquellos con asma no alérgica la presencia de antecedentes familiares de patología asmática es de un $28,4 \%$ y sólo del $13,6 \%$ en el caso de los antecedentes de atopia.

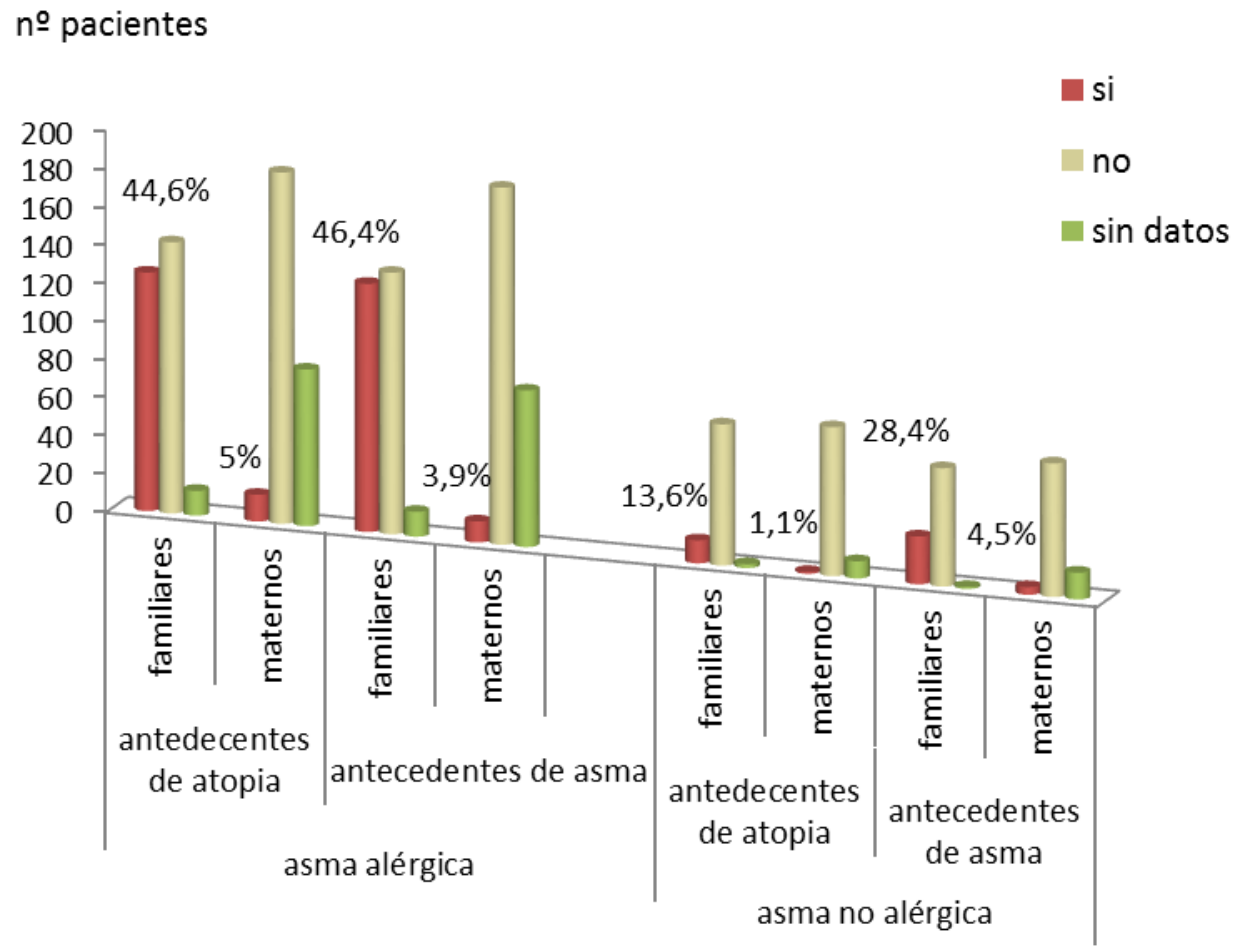

Figura 64. Antecedentes familiares de asma o atopia en pacientes de asma alérgica y asma no alérgica. En el eje de abscisas se representa la presencia de antecedentes familiares de atopia o de asma en función de la presencia o no de asma alérgica.

\section{POLÍMORFISMOS DE PTGDR EN LA POBLACÍÓN}

La tabla 2 recoge las frecuencias alélicas y genotípicas de los polimorfismos de PTGDR en la población control de este estudio. También se presentan estas mismas frecuencias obtenidas en una población europea (PGA CEPH-Panel) [232]. 
Tabla 2. Frecuencias alélicas de los polimorfismos de PTGDR en el grupo control del estudio y comparación con la población europea PGA CEPH-Panel.

\begin{tabular}{|c|c|c|c|c|c|c|}
\hline & & & & troles & PGA & PH-Panel \\
\hline & & & Alélicas & Genotípicas & Alélicas & Genotípicas \\
\hline & $-613 C>T$ & 34236606 & $\mathrm{~T}: 0,075$ & $\begin{array}{c}\text { CT: } 0,15 \\
\text { TT: } 0\end{array}$ & T: 0,087 & $\begin{array}{l}\text { CT: 0,087 } \\
\text { TT: 0,043 }\end{array}$ \\
\hline & $-549 \mathrm{~T}>\mathrm{C}$ & 8004654 & C: 0,512 & $\begin{array}{l}\text { TC: } 0,512 \\
\text { CC: } 0,256\end{array}$ & C: 0,5 & $\begin{array}{l}\text { TC: } 0,565 \\
\text { CC: } 0,217\end{array}$ \\
\hline $\begin{array}{c}\text { Promotor } \\
\text { PTGDR }\end{array}$ & $-441 C>T$ & 803010 & $\mathrm{~T}: 0,226$ & $\begin{array}{l}\text { CT: } 0,348 \\
\text { TT: 0,052 }\end{array}$ & $\mathrm{T}: 0,273$ & $\begin{array}{l}\text { CT: 0,455 } \\
\text { TT: } 0,045 \\
\end{array}$ \\
\hline & $-197 T>C$ & 11157907 & C: 0,118 & $\begin{array}{l}\text { TC: } 0,164 \\
\text { CC: } 0,036\end{array}$ & C: 0,114 & $\begin{array}{c}\text { TC: } 0,227 \\
\text { CC: } 0\end{array}$ \\
\hline & $-95 G>T$ & 41311438 & $\mathrm{~T}: 0,019$ & $\begin{array}{c}\text { GT: } 0,039 \\
\text { TT: } 0\end{array}$ & $\mathrm{~T}: 0,023$ & $\begin{array}{c}\text { GT: } 0,045 \\
\text { TT: } 0\end{array}$ \\
\hline
\end{tabular}

\section{ESTVDiO DE ASOCIAACí́N}

A continuación se describen las distintas asociaciones encontradas entre los distintos grupos de pacientes y los polimorfismos de PTGDR.

\section{ASMA}

A partir del análisis bivariante se encontraron diferencias significativas en las frecuencias genotípicas del polimorfismo $-197 \mathrm{~T}>\mathrm{C}$ del promotor de PTGDR $(p-$ Fisher $=0,009)$. El genotipo TC fue más frecuente en los pacientes con asma $(22,9 \%)$ que en los controles (16,4\%). Estos resultados fueron confirmados mediante regresión logística. Al ajustar por edad y sexo se observó que la significación se mantenía, p= 0,01 (OR: 6,49; IC 95\%: 1,56-26,99). 
El modelo recesivo de herencia para este polimorfismo presentó también diferencias significativas $(p=0,017)$, que se confirmaron al ajustar por edad y sexo, $p=0,021$ (OR: 5,05; IC 95\%: 1,27-20,05).

No se ha detectado asociación con las combinaciones haplotípicas, sin embargo, en el análisis de diplotipos se obtuvo una asociación estadísticamente significativa entre el diplotipo CCCCG/CCCTG (posiciones -613/-549/-441/-197/ -95) y el asma $(p=0,017)$. Este diplotipo fue más frecuente en los pacientes $(7,5 \%)$ que en los controles $(2,8 \%)$, asociación que se mantenía al ajustar por edad y sexo, $p=0,044$ (OR: 2,45; IC 95\%: 1,023-5,88). Sin embargo, la presencia de los diplotipos CCCCG/CCCCG y CCCC/CCCC (posiciones -613/ $-549 /-441 /-197)$ se asoció con la ausencia de asma, con valores de $p=0,004$ y $p=0,013$ respectivamente. Esta última asociación se confirmó tras el ajuste por regresión, p=0,021 (OR: 5,07; IC 95\%: 1,28-20,13).

\section{GRAVEDAD DEL ASMA}

Al analizar la gravedad del asma se encontraron asociaciones estadísticamente significativas en el caso del asma intermitente, las cuales se describen a continuación.

Se observó una asociación estadísticamente significativa $(p=0,033)$ entre el genotipo TT del polimorfismo $-613 \mathrm{C}>\mathrm{T}$ de PTGDR y el asma intermitente. Éste genotipo se detectó en el $2,7 \%$ de los pacientes mientras que no se encontró en ninguno de los miembros del grupo control. Del mismo modo se observó la asociación con el modelo recesivo de herencia $(p=0,029)$. Sin embargo, ninguna de estas asociaciones se confirmó al ajustar por sexo y edad.

Se encontraron diferencias significativas en las frecuencias genotípicas del polimorfismo $-197 T>C(p=0,011)$. El genotipo TC fue más frecuente en los 
pacientes con asma intermitente $(29,1 \%)$ que en controles $(16,4 \%)$. Estos resultados fueron confirmados mediante regresión logística, $p=0,021$ (OR: 2,13 IC $95 \%: 1,12-4,05)$.

En el caso de la asociación de este polimorfismo con el asma intermitente se detectó un modelo de herencia dominante, con una $p=0,042$. Esta asociación se confirmó para los genotipos TC ó CC con una p=0,039 (OR: 1,71 IC 95\%: 1,032,86) y sólo se mantenía incluyendo únicamente el sexo como variable de confusión en la regresión logística lo que indica que la edad podía estar interviniendo como variable de confusión.

El alelo $T$ del polimorfismo $-95 \mathrm{G}>\mathrm{T}$ resultó ser más frecuente entre los pacientes con asma intermitente (4,9\%) que en los controles $(1,9 \%), p=0,035$ (OR: 0,39; IC 95\%: 0,15-0,96).

A partir del análisis de diplotipos se obtuvo una asociación estadísticamente significativa del asma intermitente con el diplotipo CCCCG/CCCTG $(p=0,007)$ confirmada en el análisis multivariante, $p=0,018$ (OR: 4,25 IC 95\%: 1,29-14,04).

\section{ASMA ATÓPÍCA Y ASMA NO ATÓPÍCA}

El alelo C del polimorfismo $-613 \mathrm{C}>\mathrm{T}$ de PTGDR resultó más frecuente en los en los controles $(92,5 \%)$ que en los pacientes afectados de asma atópica (88,9\%), $p=0,046$ (OR: 1,54; IC 95\%: 1,004-2,36).

Se encontraron diferencias significativas en las frecuencias genotípicas del polimorfismo $-197 T>C(p=0,022)$. El genotipo TC se presentaba con una frecuencia del $22,1 \%$ en los pacientes con asma atópica mientras que en los controles era del 16,4\%, dicha asociación se confirmó mediante regresión logística, $p=0,019$ (OR: 7,63; IC 95\%: 1,39-41,84). 
En esta misma línea se detectó la asociación del asma atópica con el modelo recesivo de herencia para este polimorfismo $(p=0,029)$, confirmada al ajustar por sexo y edad, $p=0,033$ (OR: 6,61; IC 95\%: 1,16-31,69).

A partir del análisis de diplotipos se determinó la asociación entre el diplotipo CCCCG/CCCTG y el asma atópica $(p=0,019)$. La cual se mantuvo en el análisis multivariante al ajustar por el sexo, $p=0,02$ (OR: 2,81; IC 95\%: 1,17-6,75). Del mismo modo, se encontró una asociación estadísticamente significativa entre los diplotipos CCCCG/CCCCG $(p=0,011)$ y CCCC/CCCC $(p=0,029)$ y la ausencia de dicho tipo de asma; esta asociación se confirmó en el análisis multivariante en el caso del diplotipo CCCC/CCCC, $p=0,032$ (OR: 6,09; IC 95\%: 1,17-31,75).

Tanto en el análisis de los polimorfismos como en el análisis de haplotipos y diplotipos de PTGDR no se encontraron diferencias significativas entre la población de pacientes con asma no atópica y los controles. Sin embargo, al comparar los grupos de pacientes de asma atópica y no atópica, se detectó la asociación entre el asma no atópica y la presencia del diplotipo CCCCG/CTCTG $(p=0,019)$, más frecuente en los pacientes de asma no atópica $(8 \%)$ que en aquellos que padecían asma atópica (2,1\%). El análisis multivariante confirmó la asociación, $p=0,018$ (OR: 4,789; IC 95\%: 1,31-17,5).

\section{SENSíBílízACí̊́N ALÊRGíCA}

A partir del estudio de los polimorfismos de PTGDR en los pacientes con sensibilización alérgica se hallaron diferencias estadísticamente significativas ( $p$ de Fisher $<0,05$ ) en las posiciones -613 y -549 del mismo (tabla 3 ).

El alelo -613T presentó mayor frecuencia en los pacientes sensibilizados frente a algún alérgeno $(11,4 \%)$ que en los controles $(7,5 \%)(p=0,042)$. Esta misma situación se observó en los pacientes sensibilizados frente a ácaros, 
pólenes y ambos alérgenos conjuntamente, en los cuales dicho alelo estuvo presente en el $12,4 \%, 12,4 \%$ y $16,3 \%$ de los casos, respectivamente, $p=0,017$, 0,011 y 0,0007 obtenidas al comparar cada uno de estos grupos de pacientes con el grupo control (tabla 3).

Tabla 3. Estudio comparativo de las frecuencias alélicas y genotípicas de los polimorfismos - 613 y -549 de PTGDR entre controles y pacientes con sensibilidad a los distintos aeroalérgenos mediante $p$ de Fisher.

\begin{tabular}{|c|c|c|c|c|c|}
\hline \multirow{2}{*}{ Pruebas Cutáneas } & \multirow{2}{*}{$N$} & \multicolumn{4}{|c|}{ p-Fisher } \\
\cline { 3 - 6 } & & \multicolumn{2}{|c|}{$-613 C>T$} & \multicolumn{2}{|c|}{$-549 T>C$} \\
\cline { 3 - 6 } & & Alélica & Genotípica & Alélica & Genotípica \\
\hline POSITIVAS & 334 & $\mathbf{0 , 0 4 2}$ & 0,066 & 0,168 & 0,347 \\
\hline ÁCAROS & 170 & $\mathbf{0 , 0 1 7}$ & $\mathbf{0 , 0 1 8}$ & 0,06 & 0,103 \\
\hline PÓLENES & 220 & $\mathbf{0 , 0 1 1}$ & $\mathbf{0 , 0 1 8}$ & 0,179 & 0,397 \\
\hline ÁCAROS \& PÓLENES & 90 & $\mathbf{0 , 0 0 0 7}$ & $\mathbf{0 , 0 0 0 8}$ & $\mathbf{0 , 0 1 0}$ & $\mathbf{0 , 0 2 7}$ \\
\hline
\end{tabular}

Igualmente resultaron significativas las diferencias encontradas en las frecuencias del genotipo $-613 \mathrm{C}>\mathrm{T}$, más abundante entre los pacientes con sensibilización a ácaros (20\%), pólenes $(20,9 \%)$ o ambos a la vez $(25,5 \%)$ que en los controles (14,8\%). Los valores de $p$ de Fisher fueron de 0,018 en los pacientes con sensibilidad a ácaros y pólenes por separado y 0,0008 en aquellos que presentaban sensibilización conjunta (tabla 3). Al ajustar por edad y sexo para determinar la posible influencia de estas variables en las asociaciones descritas, esta asociación se mantuvo en los 3 casos; los resultados obtenidos fueron $p=0,04$ (OR: 1,82; IC 95\%: 1,03-3,23) en ácaros, $p=0,011$ OR: 2,162; IC 
95\%: 1,20-3,91) en pólenes y $p=0,003$ (OR: 2,95; IC 95\%: 1,44-6,02) en el grupo conjunto.

Tanto el modelo de herencia dominante como el recesivo de PTGDR -613 resultaron significativos en estos grupos de pacientes. En los sensibilizados frente a ácaros fue el recesivo el modelo de herencia que presentó diferencias significativas con el grupo control $(p=0,017)$. En aquellos sensibilizados frente a pólenes lo fueron ambos recesivo $(p=0,047)$ y dominante $(p=0,032)$, pero tan sólo éste último se pudo confirmar al ajustar por edad y sexo, $p=0,005$ (OR: 2,33; IC 95\%: 1,30-4,17). Esta misma situación se encontró respecto de la sensibilización frente a ambos grupos de aeroalérgenos a la vez, el modelo recesivo $(p=0,018)$ y el dominante $(p=0,043)$, significación que se mantuvo en la regresión logística, $p=0,0007$ (OR: 3,35; IC 95\%: 1,67-6,73).

Para el polimorfismo -549T>C se observaron diferencias estadísticamente significativas en las frecuencias alélicas $(p=0,01)$ y genotípicas $(p=0,027)$ entre el grupo de pacientes sensibilizados frente a ácaros y pólenes y el grupo control. El alelo C y genotipo CC se asoció con la sensibilización conjunta frente a estos alergénos, y en el caso del genotipo dicha asociación se reflejó igualmente en el análisis multivariante, $p=0,02$ (OR: 4,05; IC 95\%: 1,65-9,98).

El modelo dominante de herencia resultó significativo no sólo en este grupo de pacientes $(p=0,014)$, también en aquellos con sensibilización frente a pólenes $(p=0,047)$. En el primer caso la asociación se comprobó ajustando por las variables de edad y sexo, $p=0,014$ (OR: 2,72; IC 95\%: 1,23-6,02), y en el segundo sólo resultó significativo el ajuste por la variable sexo en la regresión logística, $p=0,04$ (OR: 1,64; IC 95\%: 1,02-2,61).

El estudio de haplotipos desveló la asociación del haplotipo TCCTG y TCCT con la sensibilización frente a pólenes $(p=0,024$ y $p=0,031)$ y a pólenes y ácaros conjuntamente $(p=0,020$ y $p=0,004)$. Dichas significaciones se 
comprobaron por regresión logística descartando la influencia de la edad o el sexo con $p=0,006$ (OR: 2,38; IC 95\%: 1,29-4,41) y $p=0,004$ (OR: 2,34 ; IC 95\%: 1,31-4,19) en el grupo de sensibilizados a pólenes y p= 0,007 (OR: 2,77; IC 95\%: 1,33-5,79) para TCCTG y $p=0,001$ (OR: 3,35; IC 95\%: 1,67-6,73) para TCCT en aquellos sensibilizados frente a pólenes y ácaros a la vez.

Finalmente en el análisis de diplotipos se determinó la asociación estadística del diplotipo CCCCG/CCCTG y la positividad en las pruebas cutáneas frente al menos un alérgeno $(p=0,022)$ que estaba presente en el $6,6 \%$ de estos individuos y sólo en el $2,8 \%$ de los controles. Al ajustar por el sexo en la regresión logística se confirmó este hallazgo, p= 0,026 (OR: 2,68; IC 95\%: 1,126,39). También se detectó una mayor frecuencia del diplotipo, CCCTG/CCCTG en los individuos sensibilizados frente a epitelios $(17,6 \%)$ que en los controles $(9,6 \%)$. Dicha asociación resultó estadísticamente significativa en el análisis bivariante y en el análisis multivariante, $p=0,008$ (OR: 3,36; IC 95\%: 1,38-8,17).

Por otro lado se encontró una asociación estadísticamente significativa entre los diplotipos CCCCG/CCCCG $(p=0,049)$ y CCCC/CCCC $(p=0,035)$ y la ausencia de sensibilización frente al menos un aeroalérgeno; confirmada en el análisis multivariante sólo en el caso del diplotipo CCCC/CCCC, $p=0,026$ (OR: 5,06; IC 95\%: 1,21 - 21,13). Este diplotipo CCCC/CCCC se presenta en el 0,9\% de estos pacientes y en un $3,6 \%$ de los controles.

\section{ASMA CON SENSíBíLIIDAD CONJVNTA A ÁCAR OS Y PÓLENES}

Se encontraron algunas asociaciones a partir del grupo de pacientes afectados de asma y sensibilidad conjunta a ácaros y pólenes. El alelo $\mathrm{C}$ de la posición -613 del promotor de PTGDR se detectó en un $82,5 \%$ de estos pacientes y en un $92,5 \%$ de los controles, diferencia que resultó estadísticamente significativa, $p=0,0007$ (OR: 2.61; IC 95\%: 1,48-4,62). En el 
análisis de las frecuencias genotípicas de este polimorfismo se determinó la asociación del mismo a la presencia de asma con sensibilidad a ácaros y pólenes $(p=0,0003)$. El genotipo CT fue más frecuente en el grupo de estos pacientes $(25,4 \%)$ que en el grupo control $(14,8 \%)$ y dicha asociación a la patología se confirmó en el análisis multivariante, $p=0,017$ (OR: 2,68; IC 95\%: $1,19-6,04)$.

El modelo dominante de herencia del SNP -613C>T se asocia en el análisis bivariante a la patología asmática con reactividad frente a estos dos grupos de aeroalérgenos $(p=0,009)$ y también en el análisis multivariante al ajustar por edad y sexo, $p=0,003$ (OR: 3,28; IC 95\%: 1,50-7,17). La diferencia en la presencia del genotipo CT o TT entre los pacientes y los controles fue en este caso de un $30,1 \%$ frente a un $14,8 \%$ respectivamente.

En el análisis de haplotipos, se obtuvo una asociación estadísticamente significativa entre los haplotipos TCCTG $(p=0,014)$ y TCCT $(p=0,009)$ y la patología asmática en combinación con la sensibilidad frente a pólenes y ácaros. En ambos casos la presencia de estos haplotipos se registró en el doble de pacientes que en controles, concretamente el $28,6 \%$ de los pacientes portaban el haplotipo TCCTG y el $30,2 \%$ el TCCT; mientras que en los controles la frecuencia de TCCTG fue del 14,4\% y de TCCT del 14,8\%. Las asociaciones se confirmaron al ajustar por edad y sexo para TCCTG, $p=0,007$ (OR: 3,01; IC 95\%: 1,36-6,64) y para TCCT, $p=0,003$ (OR: 3,28; IC 95\%: 1,50-7,17).

Se encontró una asociación estadísticamente significativa entre la presencia del diplotipo TCCTG/TCCTG y la presencia de asma atópica por ácaros y pólenes $(p=0,042)$, que no fue confirmada al ajustar por sexo y edad. 


\section{CLINICA CONCOMITTANTE A LA PRESENCIAA DE ASMA}

En el análisis de los grupos de pacientes con asma y una determinada clínica concomitante; intolerancia a los AINE, poliposis o ambas, la conocida tríada de la aspirina, se encontraron distintas asociaciones significativas ( $p$ de Fisher $<0,05)$.

Se observó una mayor presencia del alelo T del SNP de la posición -441 de PTGDR en los controles (22,6\%) respecto de los pacientes con asma afectados también de poliposis $(15,3 \%)$, diferencia estadísticamente significativa, $p=0,042$ (OR: 1,62; IC 95\%: 1,01-2,58).

El modelo dominante de herencia para este mismo polimorfismo pese a no resultar significativo en el análisis bivariante, si lo fue en el análisis multivariante, p= 0,041 (OR: 1,76; IC 95\%: 1,02-3,03) siendo los genotipos CT o TT más frecuentes en controles (40\%) que en pacientes $(27,9 \%)$.

A partir del análisis de haplotipos se detectó una diferencia estadísticamente significativa en la presencia del haplotipo CTTTG en el grupo de individuos afectados de asma y poliposis $(p=0,026)$, siendo más frecuente en el grupo de controles (36,8\%) que en estos pacientes (17,4\%). La asociación se confirmó al ajustar por edad y sexo, $p=0,016$ (OR: 2,23; IC 95\%: 1,16-4,27).

Por otro lado se obtuvo la asociación del haplotipo CTCTG y la tríada de la aspirina $(p=0,030)$, que se mantuvo en el análisis multivariante $(p=0,033$ (OR: 2,74; IC 95\%: 1,08-6,92). La presencia de este haplotipo en estos pacientes fue del $64 \%$ frente a un $42,4 \%$ en que se detectó en los controles.

En el análisis de diplotipos se determinó la asociación del diplotipo CCCCG/CCCTG y la presencia conjunta de asma y poliposis $(p=0,036)$ y se confirmó en el análisis multivariante, $p=0,032$ (OR: 3,43; IC 95\%: 1,11-10,60). 
Mientras este diplotipo está presente en el 7\% de estos pacientes, sólo se detecta en el 2,8\% de los controles.

Se encontraron diferencias significativas en la distribución del diplotipo CTCTG/TCCTG en los tres grupos de pacientes con asma y presencia concomitante de intolerancia a los AINE, poliposis y tríada de la aspirina, tanto en el análisis bivariante como en el análisis multivariante tal y como se recoge en la tabla 4.

Tabla 4. Frecuencias y valores de $\mathrm{p}$ de Fisher de la asociación del diplotipo CTCTG/TCCTG en los pacientes con intolerancia a los AINE (iAINE), poliposis y tríada de la aspirina.

\begin{tabular}{|c|c|c|c|c|c|}
\hline \multirow{2}{*}{ CLÍNICA } & \multicolumn{2}{|c|}{ FRECUENCIAS } & \multirow{2}{*}{$\begin{array}{l}\text { BIVARIANTE } \\
\text { p de Fisher }\end{array}$} & \multicolumn{2}{|c|}{ MULTIVARIANTE } \\
\hline & Controles & Pacientes & & $p$ de Fisher & Odds Ratio (OR; IC 95\%) \\
\hline iAINE & \multirow{3}{*}{$3,2 \%$} & $11,5 \%$ & 0,018 & 0,013 & 4,$15 ;(1,34-12,84)$ \\
\hline POLIPOSIS & & $8,1 \%$ & 0,022 & 0,019 & 3,$55 ;(1,23-10,20)$ \\
\hline $\begin{array}{l}\text { TRÍADA de } \\
\text { la aspirina }\end{array}$ & & $16 \%$ & 0,015 & 0,007 & 5,$87 ;(1,62-21,28)$ \\
\hline
\end{tabular}

\section{ANTECEDENTES FAMILIARES DE ASMA ๑ ATOPIA}

\section{ANTECEDENTES DE ASMA}

Al comparar el grupo de pacientes afectados de asma con antecedentes familiares de esta patología y el grupo de controles, se encontraron diferencias estadísticamente significativas en las frecuencias genotípicas del polimorfismo -197 de PTGDR $(\mathrm{p}=0,011)$. La asociación del genotipo TC, presente en el 27,6\% de estos pacientes y en el $16,4 \%$ de los controles, con los antecedentes 
familiares de asma fue confirmada por análisis multivariante, $p=0,044$ (OR: 1,72; IC 95\%: 1,01-2,92).

En el análisis de diplotipos se obtuvo la asociación del diplotipo CCCCG/CCCTG con los antecedentes familiares de asma $(p=0,019)$, asociación que se mantuvo al ajustar por el sexo, $p=0,021$ (OR: 3,04; IC 95\%: 1,19-7,81).

\section{ANTECEDENTES DE ATOPIA}

A partir del estudio bivariante de los polimorfismos de PTGDR en los pacientes con antecedentes familiares de atopia se encontraron diferencias estadísticamente significativas a nivel genotípico en las posiciones $-613(p=$ $0,041)$ y $-197(p=0,026)$ del promotor de este gen. En ambos casos el genotipo heterocigoto resultó más frecuente en pacientes (-613CT: 19,2\% y -197TC: 26,5\%) que en controles (-613CT: 14,8\% y -197TC: 16,4\%), asociándose con los antecedentes de atopia. Dichas asociaciones se mantuvieron tras ajustar por edad y sexo en el caso de $-613 \mathrm{CT}, \mathrm{p}=0,027$ (OR: 2,09; IC 95\%: 1,09-4,01) y sólo por la variable sexo para -197TC, $p=0,021$ (OR: 1,79; IC 95\%: 1,09-2,93).

\subsection{ESTVDIO FVNCIONAL DEL PROMOTOR DE PTGDR}

\section{ENSAYOS DE RETARDO EN GEL}

Los ensayos de retardo en gel han permitido identificar determinadas proteínas de unión al ADN que reconocen específicamente las secuencias estudiadas. Los 5 polimorfismos del promotor de PTGDR analizados en este trabajo, $-613 \mathrm{C}>\mathrm{T}, \quad-549 \mathrm{~T}>\mathrm{C}, \quad-441 \mathrm{C}>\mathrm{T},-197 \mathrm{~T}>\mathrm{C}$ y $-95 \mathrm{G}>\mathrm{T}$ han presentado 
distintos patrones de movilidad electroforética en los ensayos de retardo en gel (figura 65).

Se han detectado complejos ADN:proteína con diferentes propiedades estequiométricas y conformacionales en función del nucleótido presente en la posición -613 del promotor de PTGDR. El patrón de migración de los complejos de las proteínas nucleares con la región -613C/G (figura 65. recuadro -613 C>T. banda A) es muy diferente al que encontramos en la región portadora del polimorfismo $-613 T / A$ (figura 67 , recuadro $-613 \mathrm{C}>\mathrm{T}$ bandas $\mathrm{A}$ y $\mathrm{C}$ ). Estas bandas específicas se diferencian de complejos inespecíficos gracias a la reacción en ausencia de proteínas [figura 67, recuadro -613 C>T (1)] y a la reacción con el oligonucleótido competidor [figura 67, recuadro -613 C>T (3)], en las cuales la banda del complejo inespecífico se mantiene (figura 67 recuadro $-613 \mathrm{C}>\mathrm{T}$, banda $\mathrm{B})$.

Por otro lado, se detectó una marcada diferencia en la intensidad del marcaje en los ensayos de la secuencia $-613 \mathrm{C} / \mathrm{G}$ respecto de aquellos con los oligonucleótidos $_{\mathrm{ds}}-613 \mathrm{~T} / \mathrm{A}$, en todas las reacciones. Sin embargo está diferencia no se apreció en el testaje del marcaje previo a los ensayos.

Las condiciones de los ensayos de retardo en gel establecidas en este trabajo no nos han permitido detectar diferencias en la movilidad electroforética entre los complejos ADN:proteína formados en las posiciones conservadas $-549 T / A,-441 \mathrm{C} / \mathrm{G}$ y $-197 \mathrm{~T} / \mathrm{A}$ y las correspondientes mutadas; -549C/G, $-441 \mathrm{~T} / \mathrm{A}$ y -197C/G. Sin embargo, en los tres casos se ha observado la unión específica de las proteínas del extracto nuclear al ADN en estas tres regiones del promotor de PTGDR (figura 65. recuadros $-549 \mathrm{~T}>\mathrm{C},-441 \mathrm{C}>\mathrm{T},-197 \mathrm{~T}>\mathrm{C}$. bandas $\mathrm{A}$ ), gracias a la comparativa con las reacciones con el oligonoucleótido ${ }_{\mathrm{ds}}$ competidor. 


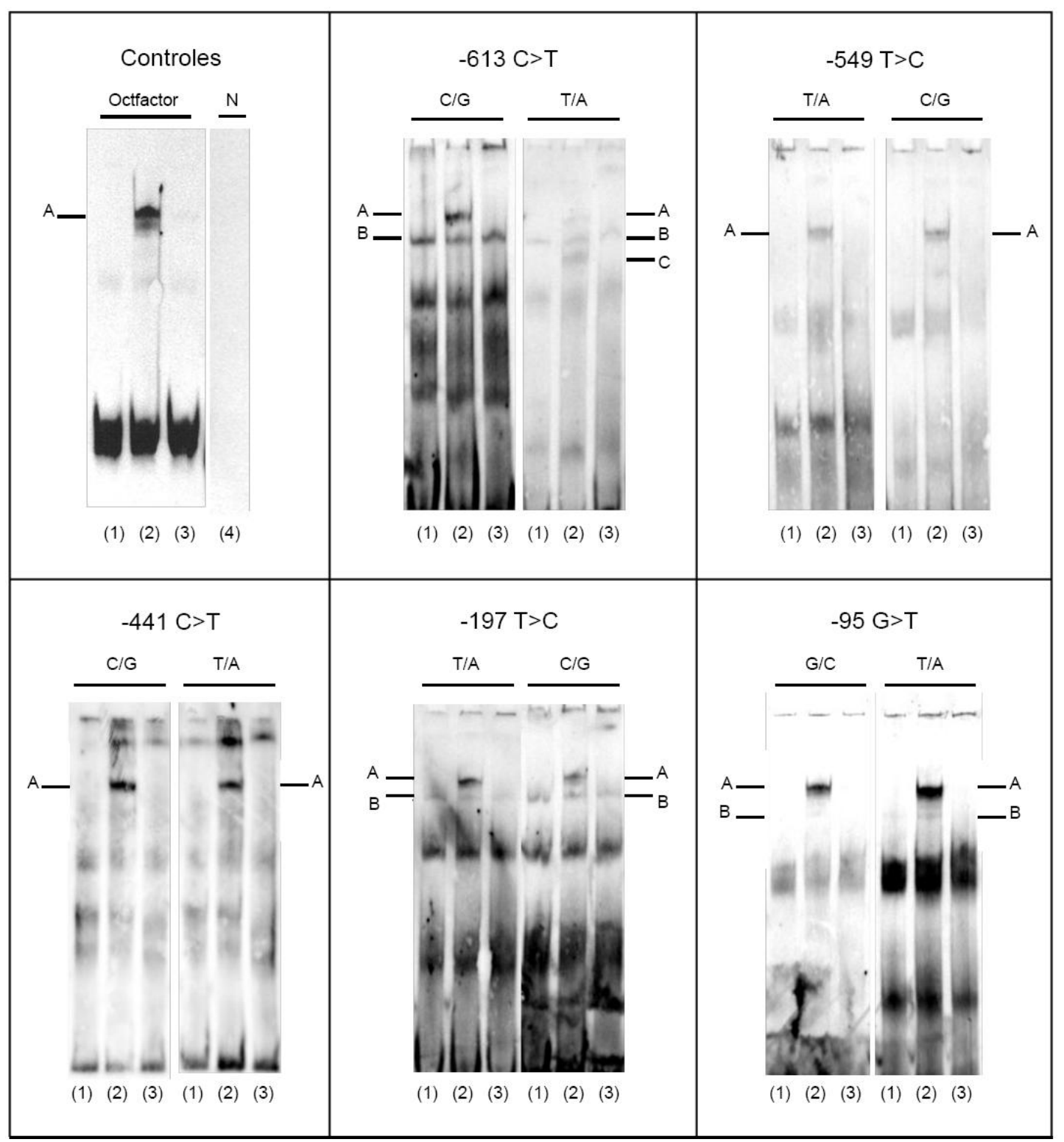

Figura 65. Ensayos de retardo en gel en las posiciones -613, -549, -441, -197 y -95 del promotor de PTGDR. Estudio de los posibles efectos de estas variantes en la unión de factores de trascripción a esta región promotora. (1): Oligonucleótido $\mathrm{ds}_{\mathrm{ds}}$ marcado en ausencia de proteínas nucleares o deoligonucleótido ${ }_{d s} \sin$ marcar,

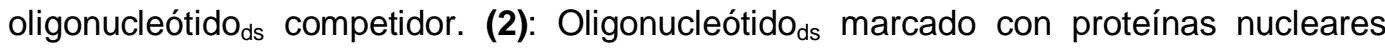

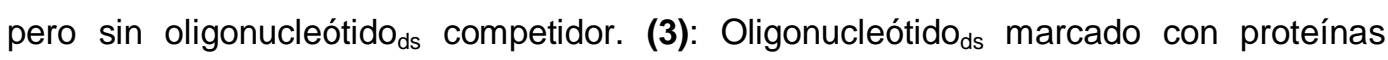
nucleares y oligonucleótido ${ }_{d s}$ competidor. (X25). (4): Control negativo: tampón de la reacción de unión. 


\section{ANÁLíSíS İN SíLİCO}

Los resultados del estudio in silico de los efectos de las variantes del promotor de PTGDR analizadas en este trabajo se muestran en la tabla 5 . Se han detectado diferencias en la unión de determinados factores de transcripción entre la posición conservada y la mutada en cada una de ellas (tabla 5).

El algoritmo de Eldorado propone la unión del factor de transcripción ZNF336 (proteína dedo de Zinc 336) en relación a la posición -613 del promotor de PTGDR, mientras que el cambio de Timina por Citosina en este punto supone la pérdida de dicha unión. Por otro lado, el otro algoritmo TESS propone la interacción del factor $\mathrm{C} / \mathrm{EBP} \alpha$ en torno a dicho polimorfismo en presencia del nucleótido conservado.

Respecto a la posicion -549T>C se describe un numeroso grupo de proteínas candidatas a interaccionar con dicha región por ambos algoritmos. La presencia del polimorfismo en este caso produce tanto la pérdida de la unión de factores de trascripción como BACH1, NF-BA1, NP-TClI, MNB1a, NF1, el homodímero de PPAR-y, los heterodímeros VDR/RXR y CAR/RXR y los monoméros de la familia Nur, como la interacción adicional de otros factores como el heterodímero PPAR/RXR, GABP y PAX-6.

A partir del cambio de nucleótido en el nucleótido -441 de PTGDR el factor silenciador restrictivo neuronal NRSF y el factor Sp1 dejan de interaccionar con esta región. El heterodímero PPAR/RXR y $\mathrm{C} / \mathrm{EBPa}$ se une a la secuencia portadora del polimorfismo y no a la posición conservada. 
Tabla 5. Resultados del análisis in silico del promotor de PTGDR con las plataformas de EIDorado y Tess. En negrita se representan los Factores cuya unión se ve modificada al introducir el cambio de nucleótido correspondiente en cada SNP.

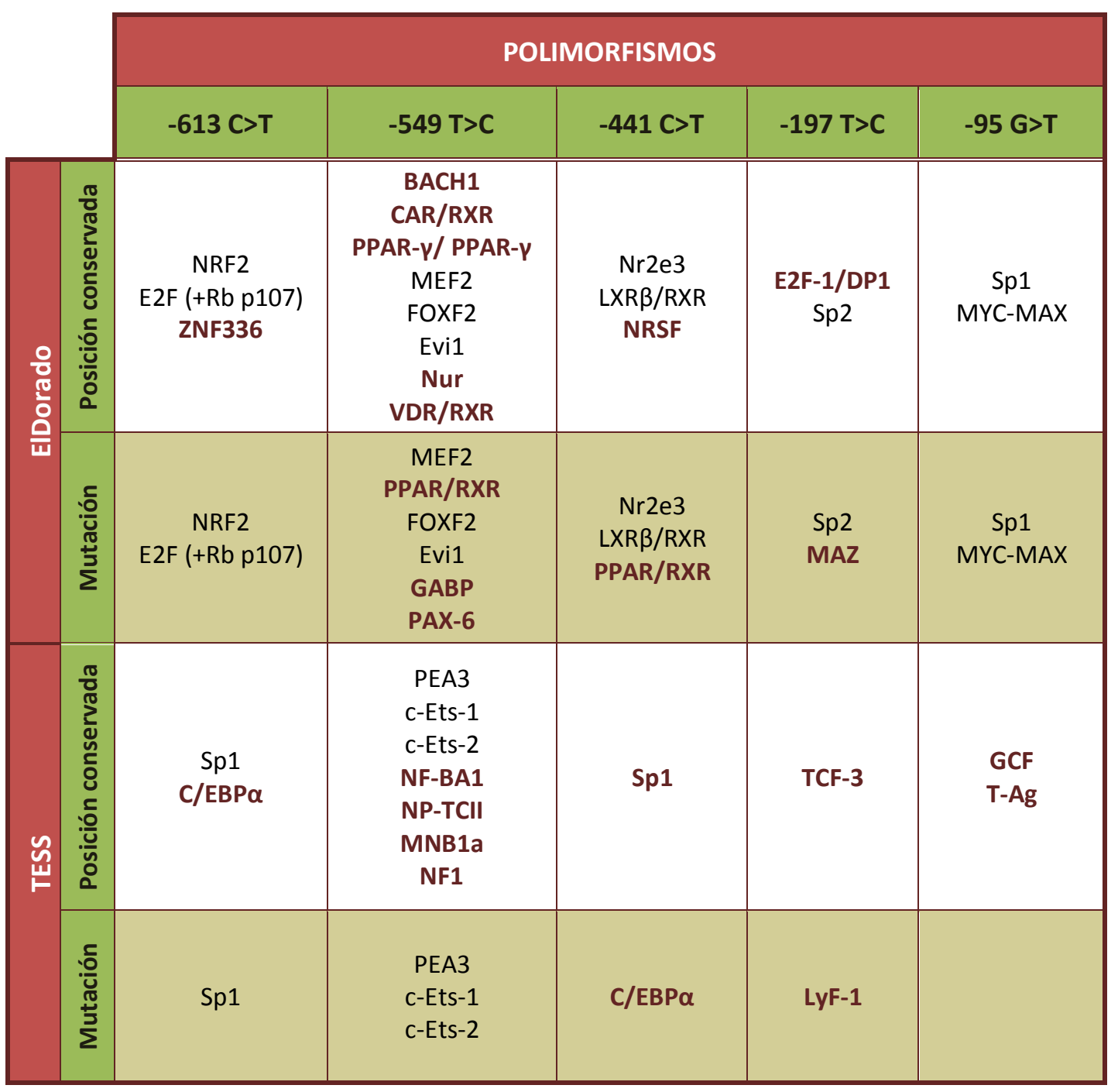

NRF2 (Nuclear factor (erythroid-derived 2)-like 2): Factor 2 relacionado con el factor nuclear eritroide-2. E2F (+Rb p107): Familia de factores de transcripción E2F junto con la proteína p107 tipo proteína del retinoblastoma (Rb). ZNF336 (Zinc finger protein 336): Proteína dedo de Zinc 336. Sp1 (Stimulating protein 1): Proteína estimuladora 1. BACH1 (BTB and CNC homology 1, basic leucine zipper transcription factor 1): factor de

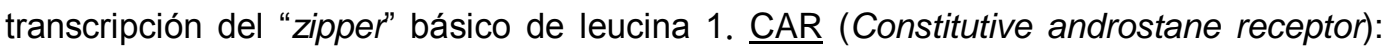
Receptor constitutivo de androstano. $\underline{\mathrm{RXR}}$ (retinoid $X$ receptor): Receptor Xretinoide. PPAR-Y (Peroxisome proliferator-activated receptor gamma): Receptor gamma activador de la proliferación de peroxisomas. MEF2 (Myocyte-specific enhancer factor 2): Factor potenciador específico de miocito tipo 2. FOXF2 (Forkhead related transcription factor-2). 
Evi1 (Ecotropic viral integrationsite 1 encoded factor): Nur: Subfamilia de factores de transcripción tipo Nur (nur77, nurr1, nor-1). VDR: (Vitamin D receptor): Receptor de la vitamina D. GABP (GA binding protein): Proteínas de unión a secuencias ricas en GA. PAX-6 (Paired box protein 6). Nr2e3 (Photoreceptor-specific nuclear receptor subfamily 2, group E, member 3): Receptor nuclear 3 del grupo $E$ de la subfamilia 2. LXRß (Liver $X$ receptor): Receptor hepático X. NRSF (Neuron restrictive silencer factor): Factor silenciador restrictivo neuronal. DP1: Factor de transcripción activador de la transcripción dependiente de la familia E2F. Sp2 (Stimulating protein 2): Proteína estimuladora 2. MAZ (Myc associated zinc finger protein): Proteína con dedo zinc asociada a Myc. MYC/MAX (Myelocytomatosis oncoprotein/Myc-associated factor $X$ ). $\underline{\mathrm{C} / \mathrm{EBPa}}$ (CCAAT/enhancer binding protein alpha): Proteína alfa de unión al potenciador CCAAT. PEA3: Subfamilia de factores de la familia ETS. ETS (E-twenty-six family): Familia ETS. NF-BA1 (Nuclear factor BA1): Factor nuclear BA1. NP-TCII: Factor de transcripción TCII. MNB1a (=Dof1): Factor con dominio Dof. NF1 (Nuclear factor 1): Factor nuclear 1. TCF-3 (T-cell factor 3): Factor derivado de células T. LyF-1 (lymphoid transcription factor 1): Factor de transcripción linfoide 1. GCF (GC factor): Factor GC.

Finalmente el dímero formado por E2-F y DP-1, y el factor TCF-3 interacciona únicamente con la región del nucleótido conservado en posición -197 de PTGDR (T/A). Mientras que sólo en presencia de la mutación se produce la unión de la proteína asociada a los factores Myc (MAZ) y LyF-1 al promotor de PTGDR.

Por último, la interacción de los factores GCF y T-Ag con el promotor de PTGDR se pierde con la variante en posición -95 G>T. Por el contrario, según el algoritmo de EIDorado la presencia de este polimorfismo no determina diferencias en la unión de los factores de transcripción en torno a esta región.

Merece la pena destacar la presencia de importantes complejos como VDR/RXR y PPAR/RXR relacionados con las vías del ácido retinoico y la vitamina D. 


\subsection{1 İDENTíFíCACí์́N DE FACTORES DE TRANSCRİPCí́N}

\section{PVRIIFICACACí́N DE PR OTEÍNAS DE VNİ́N AL ADN}

La purificación de las proteínas formadoras de los complejos ADN:proteína a partir de los ensayos de retardo en gel no superaron la fase de síntesis de los concatémeros. No fue posible la puesta a punto metodológica de este procedimiento según las citadas condiciones. En todos los casos se producían grandes moléculas de ADN que no llegaban a penetrar en los geles de agarosa en los cuales fueron analizados los concatémeros, y que fueron polimerizados a distinta concentración (figura 66). Aparentemente el comportamiento de los oligonucleótidos control era diferente, no se encontraron las citadas moléculas de $A D N$ de gran tamaño pero tampoco se registró el conjunto de bandas de distintos tamaños desde 5 a 40 Kb característico de la concatemerización.

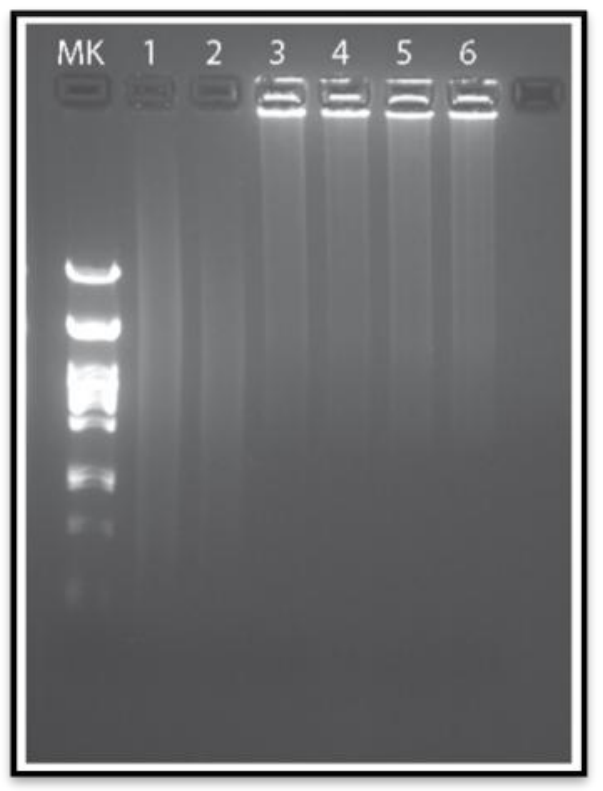

Figura 66. Electroforesis de los fragmentos amplificados por PCR autocebada. Se visualizan los productos de la concatemerización correspondientes al control positivo ( 1 y 2), y a los cebadores -613C/G (3 y 4) y $-613 T / A$ (5 y 6) en relación al marcador de peso molecular del fago $\lambda$ digerido con Pstl. 


\section{SHIFT - WESTERN BLOTTINA}

En los experimentos de shift-western se detectó la proteína control Oct2A mediante el anticuerpo policlonal anti-Oct-2 empleado y a partir del complejo formado con los oligonucleótidos que contenían la secuencia de unión a la misma (figura 67. banda A). Para este ensayo se seleccionaron los factores E2F y DP1. No se confirmó la presencia de dichos factores en los complejos ADN:proteína formados en relación con las posiciones -613C>T y -197T>C de PTGDR.

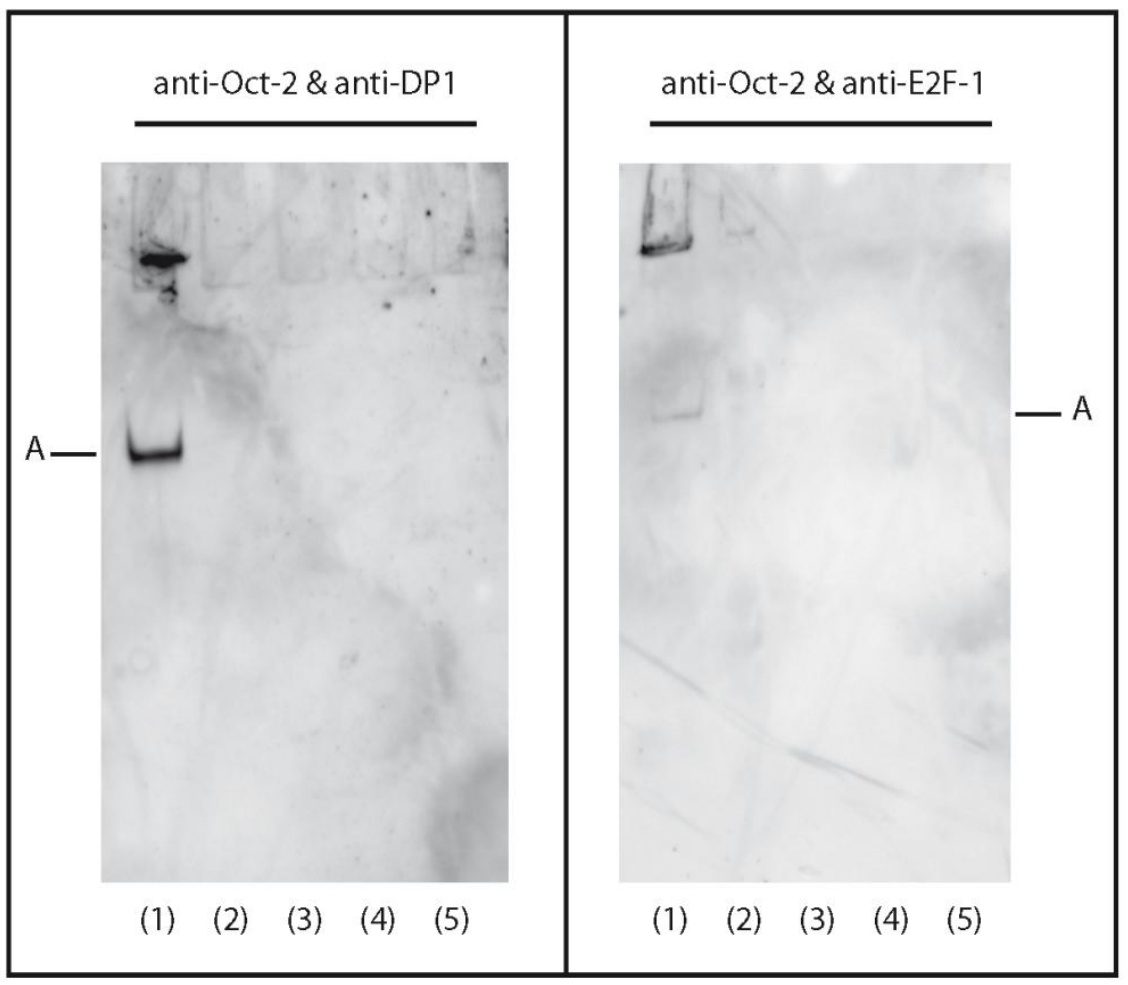

Figura 67. Ensayos de shift-western en las posiciones -613, y -197 del promotor de PTGDR. Reacciones de formación de los complejos ADN:proteína con el extracto de proteínas nucleares y los oligonucleótido ${ }_{d s} \sin$ marcar: (1): Oligonucleótido ${ }_{d s}$ control.(2):Oligonucleótido ${ }_{d s}-613 C / G$.(3):Oligonucleótido $d s-613 T / A$. (4): Oligonucleótido $d_{d s}$ -197T/A. (5): Oligonucleótido $-197 \mathrm{ds} / \mathrm{G}$. 


\section{ELECTR OFORESIS DE PROTEINAAS Y WESTERN BLOTTINNG}

El análisis del extracto proteico mediante electroforesis en condiciones desnaturalizantes y western blotting nos aportó datos relevantes, no sólo en cuanto a la muestra de proteínas, sino también en la valoración de los propios anticuerpos (figura 68). En concreto, a partir de este ensayo y los anticuerpos anti-E2F-1 y anti-DP1 se determina que ninguno de estos factores estaría en el extracto proteico en una cantidad detectable por esta metodología, mientras que se registra la señal del control positivo mediante el anticuerpo anti-Oct-2 (figura 68 , A). Por otro lado hemos encontrado cierta inespecificidad en el anticuerpo frente al factor de transcripción E2F-1 a partir de las señales detectadas en el marcador de peso molecular proteico en la membrana hibridada con él (figura 68, C, D y E). Incluso el anticuerpo anti-DP1 podría reaccionar con la proteína control Oct2A (figura 68, B).

anti-DP1 y anti-Oct-2

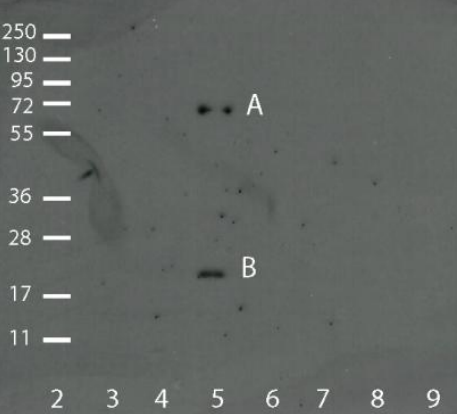

anti-E2F-1 y anti-Oct-2

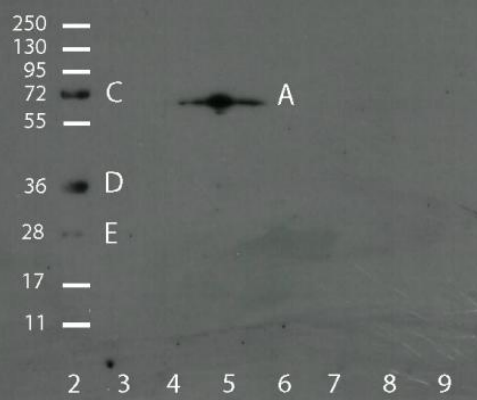

Figura 68. Western blotting del extracto proteico comercial empleado y la proteína control Oct2A. (2): Marcador de peso molecular, tamaños expresados en kDa. (3, 7 y 9): Extracto proteico en distintas cantidades (5): Control Oct2A. (4, 6 y 8): Pocillos sin ningún contenido. 


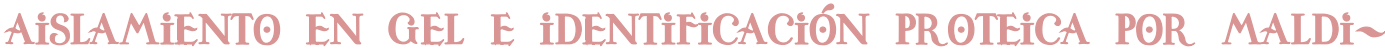

\section{$\mathrm{TOF} / \mathrm{TOF}$}

El análisis de los fragmentos de gel de poliacrilamida con los complejos ADN:proteína retenidos presentó distintos problemas. Uno de ellos fue la escasez de muestra y el otro, importante, la contaminación de las muestras con queratinas (figura 69), lo que obligó a realizar el ensayo en dos etapas.

En el primer ensayo, a partir de la fragmentación de algún péptido que no correspondía a queratinas, se observó una posible modificación en la secuencia, en concreto una acetilación. Por homología de secuencia se identificó únicamente un péptido tipo calicreína (figura 70).

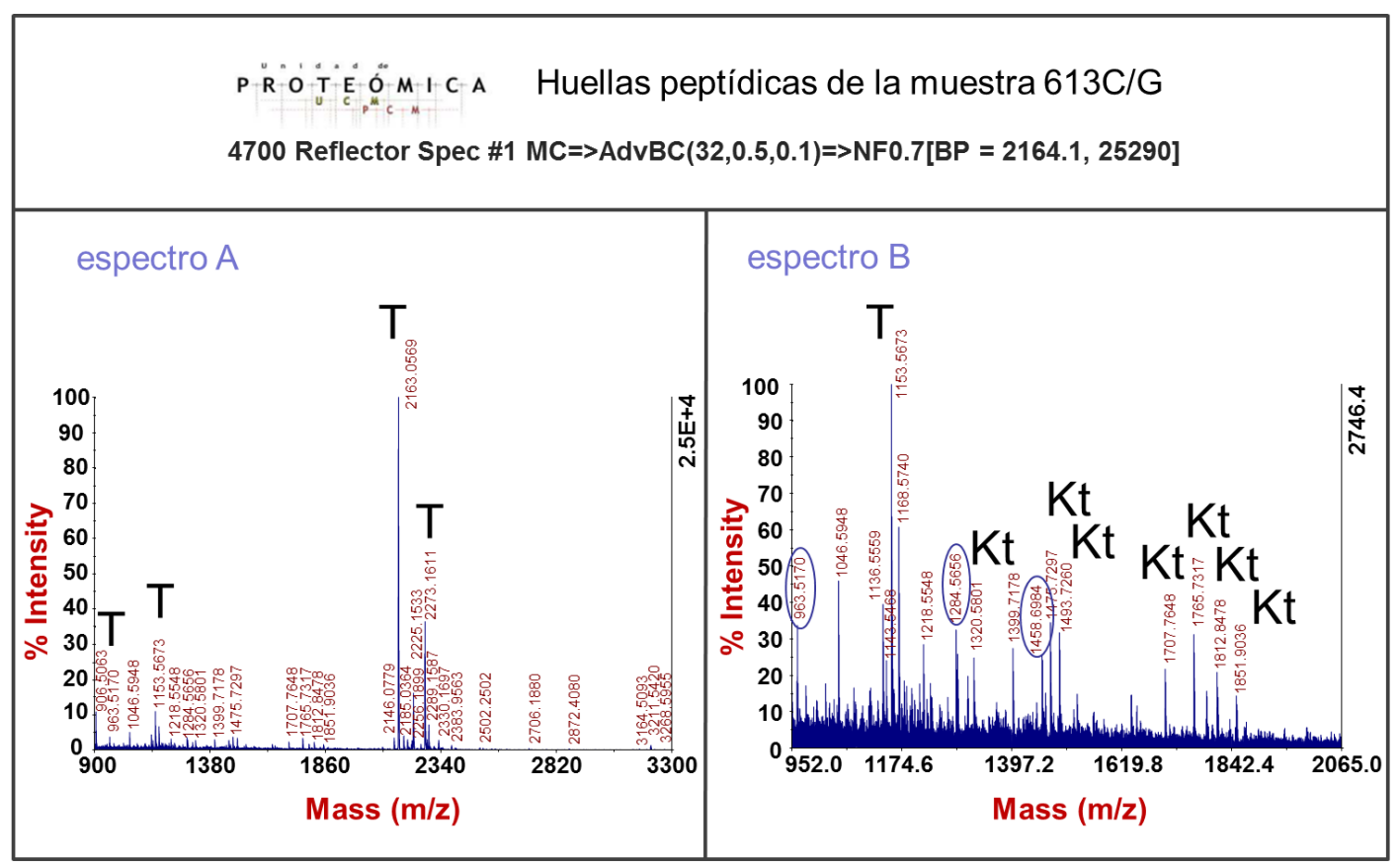

Figura 69. Espectros de masas de la muestra 613C/G. En ambos se detecta la presencia de tripsina $(T)$ con la que se realizó el proceso de digestión, así como se aprecia la contaminación por queratinas $(\mathrm{Kt})$ en el espectro B. Los tres fragmentos rodeados en azul en el espectro $B$ fueron seleccionados para el análisis de $\mathrm{ms} / \mathrm{ms}$ $(1458.7,1284.57$ y 963.5$)$. 


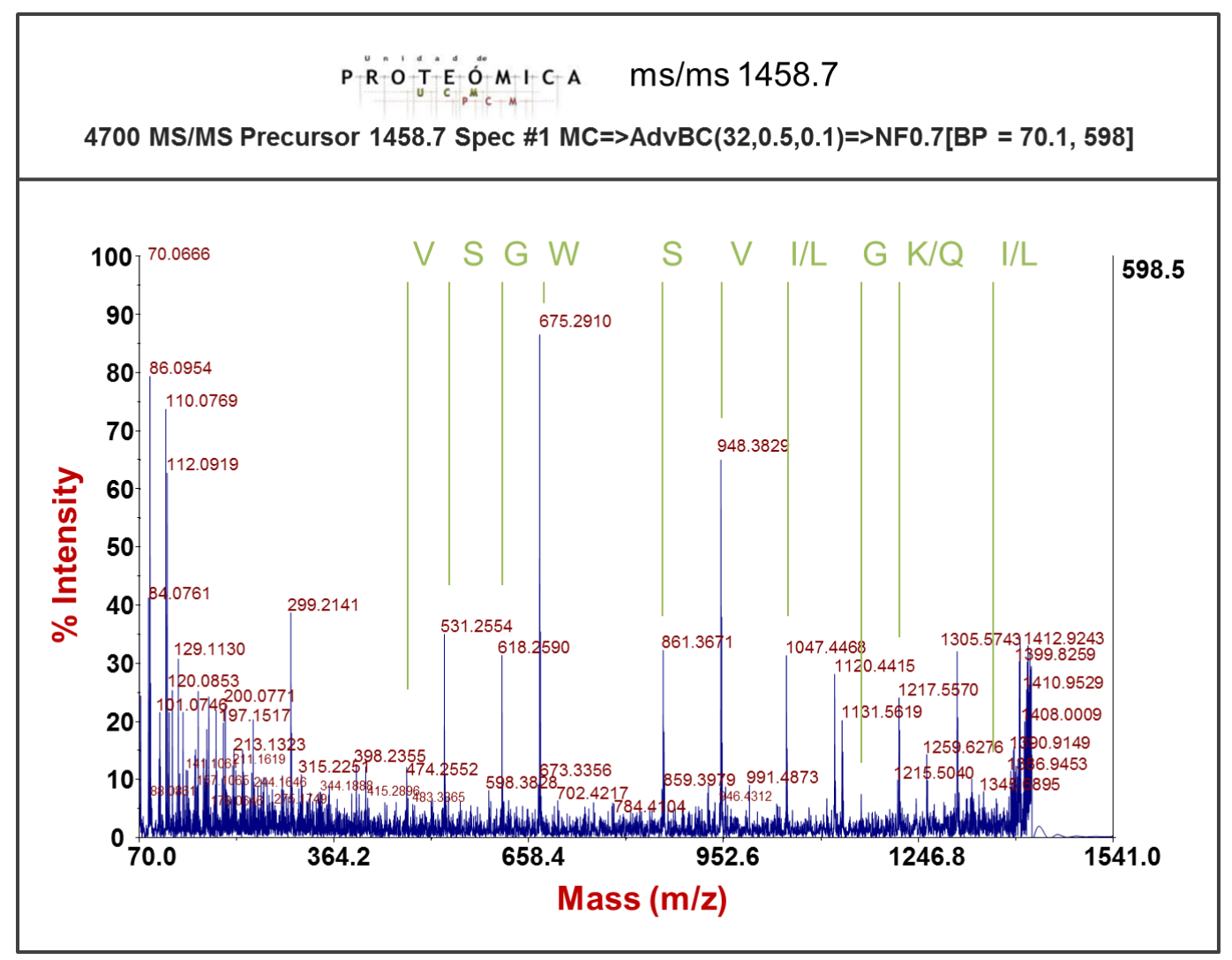

Figura 70. Espectro masas/masas (ms/ms) del péptido 1458.7 procedente del espectro de masas de la muestra $613 \mathrm{C} / \mathrm{G}$. En verde se representan los aminoácidos integrantes de dicho péptido, entre los cuales hay dos aminoácidos isobáricos, leucina e isoleucina (L/I). Dicha secuencia de 10 aminoácidos (LQGLVSWGSV) se identifica tras su análisis en el programa BLAST (www.ncbi.nlm.nih.gov/blast) como tipo calicreina. (L: Leucina, Q: Glutamina, G: Glicina, V: Valina, S: Serina, W: Triptófano).

Posteriormente, se procedió a un segundo aislamiento de proteína para conseguir mayor concentración extremando las condiciones para evitar posibles contaminaciones con queratinas. Se obtuvieron unos resultados preliminares que fueron sometidos a reanálisis en los que se pusieron de manifiesto algunos polipéptidos (tabla 6) que si bien no se detectaron en cantidad suficiente para superar el umbral si son orientativos sobre posibles factores de transcripción que puedan estar actuando sobre esta región promotora. 
En la tabla 6 se indican los factores de transcripción que se han identificado mediante espectrometría de masas para el SNP -613, entre los que se incluyen varios factores con motivos en dedos de zinc.

Tabla 6. Resultados del análisis por espectrometría de masas de las distintas bandas ADN:proteína detectadas en los ensayos de retardo en gel en torno a la posición -613 del promotor de PTGDR.

\begin{tabular}{|c|c|c|c|}
\hline SNP & Bandas & $\begin{array}{l}\text { FACTOR DE } \\
\text { TRANSCRIPCIÓN }\end{array}$ & DEFINICIÓN \\
\hline $613 \mathrm{C} / \mathrm{G}$ & A & SNX11_HUMAN & $\begin{array}{l}\text { Sorting nexin-11 OS=Homo sapiens } G N=S N X 11 \\
\qquad P E=2 S V=2\end{array}$ \\
\hline \multirow{12}{*}{$613 \mathrm{~T} / \mathrm{A}$} & \multirow{2}{*}{ A } & ZN502_HUMAN & $\begin{array}{l}\text { Zinc finger protein } 502 \mathrm{OS}=\text { Homo sapiens } \\
\text { GN=ZNF502 PE=2 SV=1 }\end{array}$ \\
\hline & & ZN823_HUMAN & $\begin{array}{c}\text { Zinc finger protein } 823 \mathrm{OS}=\text { Homo sapiens } \\
\mathrm{GN}=\mathrm{ZNF} 823 \mathrm{PE}=2 \mathrm{SV}=2\end{array}$ \\
\hline & \multirow{10}{*}{ B } & ZN224_HUMAN & $\begin{array}{l}\text { Zinc finger protein } 224 \mathrm{OS}=\mathrm{Homo} \text { sapiens } \\
\mathrm{GN}=\mathrm{ZNF} 224 \mathrm{PE}=1 \mathrm{SV}=2\end{array}$ \\
\hline & & CD28_HUMAN & $\begin{array}{l}\text { T-cell-specific surface glycoprotein CD28 } \\
\text { OS=Homo sapiens GN=CD28 PE=1 SV=1 }\end{array}$ \\
\hline & & NALP7_HUMAN & $\begin{array}{l}\text { NACHT, LRR and PYD domains-containing protein } \\
7 \text { OS=Homo sapiens GN=NLRP7 PE }=1 \mathrm{SV}=1\end{array}$ \\
\hline & & RAB2B_HUMAN & $\begin{array}{l}\text { Ras-related protein Rab-2B OS=Homo sapiens } \\
\qquad \mathrm{GN}=\mathrm{RAB} 2 \mathrm{~B} P E=1 \mathrm{SV}=1\end{array}$ \\
\hline & & WDFY2_HUMAN & $\begin{array}{l}\text { WD repeat and FYVE domain-containing protein } \\
2 \text { OS=Homo sapiens } G N=W D F Y 2 P E=2 S V=2\end{array}$ \\
\hline & & DCTD_HUMAN & $\begin{array}{l}\text { Deoxycytidylate deaminase OS=Homo sapiens } \\
\qquad G N=D C T D P E=1 S V=2\end{array}$ \\
\hline & & HXD10_HUMAN & $\begin{array}{l}\text { Homeobox protein Hox-D10 OS=Homo sapiens } \\
\qquad \mathrm{GN}=\mathrm{HOXD} 10 \mathrm{PE}=1 \mathrm{SV}=2\end{array}$ \\
\hline & & DYN1_HUMAN & $\begin{array}{l}\text { Dynamin-1 OS=Homo sapiens GN=DNM1 PE=1 } \\
\qquad S V=2\end{array}$ \\
\hline & & BEND5_HUMAN & $\begin{array}{c}\text { BEN domain-containing protein } 5 \mathrm{OS}=\text { Homo } \\
\text { sapiens } \mathrm{GN}=\mathrm{BEND5} \mathrm{PE}=1 \mathrm{SV}=1\end{array}$ \\
\hline & & TMOD3_HUMAN & $\begin{array}{l}\text { Tropomodulin-3 OS=Homo sapiens GN=TMOD3 } \\
\qquad \mathrm{PE}=1 \mathrm{SV}=1\end{array}$ \\
\hline
\end{tabular}





\section{DíSCVSí̄́N}

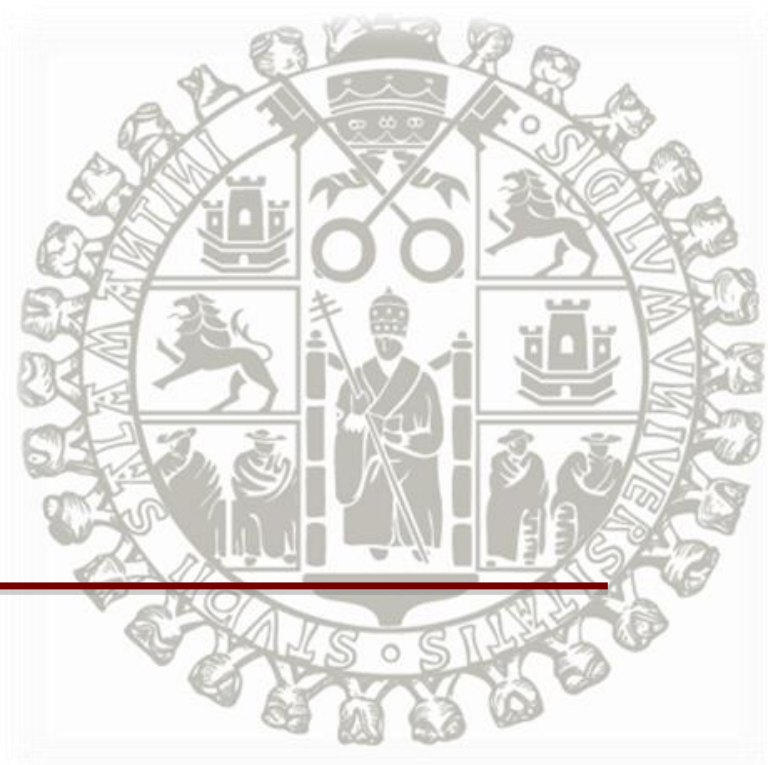





\section{DiSCVSi@́N}

El receptor de la prostaglandina $D_{2}$, PTGDR, codificado por el gen homónimo, PTGDR, es responsable de algunas de las funciones efectoras de este mediador inflamatorio en el proceso fisiopatológico del asma y otras afecciones relacionadas, como la rinitis alérgica y la dermatitis atópica. Su activación contribuye a la vasodilatación pulmonar, la broncoconstricción, el reclutamiento de eosinófilos, linfocitos $\mathrm{T}$ y basófilos, y la potenciación de la síntesis de la propia $\mathrm{PGD}_{2}[176]$.

En este trabajo se han estudiado 4 polimorfismos localizados en la región promotora del gen PTGDR; -613 C>T (rs34236606), -549T>C (rs8004654), $-441 \mathrm{C}>\mathrm{T}$ (rs803010) y $-197 \mathrm{~T}>\mathrm{C}$ (rs11157907), descritos anteriormente en la literatura por su asociación con la patología asmática y la alergia. A partir del análisis de las secuencias hemos analizado una quinta variante génica, localizada a 95 pares de bases del inicio de la transcripción, correspondiente al polimorfismo $-95 \mathrm{G}>\mathrm{T}$ ( $\mathrm{rs} 41311438)$.

Los 675 individuos que han participado en el estudio y las 131 variables analizadas en él, entre las que se incluyen estos 5 polimorfismos, han originado un conjunto de datos que supera la cifra de 88.000 ; los resultados de su análisis serán comentados a continuación. 


\title{
6.1 ASOCiACIÓN GÉNiCA DEL GEN PTGDR CON EL
}

\begin{abstract}
ASMA
\end{abstract}
POLíMORFISMOPTGDR -95G>T

En este estudio se analiza por primera vez en pacientes asmáticos de origen caucásico, un polimorfismo caracterizado por el cambio de la guanina de la posición -95 de la región promotora del gen PTGDR por una timina. Tanto la frecuencia del alelo T como las frecuencias genotípicas GT o TT registradas son escasas en el conjunto de la muestra secuenciada; así, sólo se ha encontrado un individuo portador de la variante en homocigosis (TT), concretamente en un paciente con asma intermitente alérgico a los pólenes. Estos resultados, por otro lado, están en concordancia con los hallados en otras poblaciones. De hecho, esta variante del promotor de PTGDR fue estudiada junto con otras once en un trabajo de asociación de este gen y el asma [204]. De los 12 SNP que se identificaron, seis se describieron como nuevos polimorfismos, entre ellos el de la posición -95 de la región promotora de este gen. Sin embargo, ninguna de estas nuevas variantes fue incluida en el estudio de asociación con el asma, dada su baja frecuencia, menor del $5 \%$ en el conjunto de las tres poblaciones estudiadas en dicho trabajo.

En el estudio individual de los polimorfismos analizados en este trabajo se ha encontrado una asociación estadísticamente significativa del alelo T del SNP $-95 G>T$ con el asma intermitente. No obstante y teniendo en cuenta la escasa representatividad del alelo T en nuestra población, no se puede constatar su contribución para ese genotipo. 
Por otro lado, la propuesta metodológica del empleo simultáneo de dos endonucleasas isoesquizómeras, Aval y $B s o B I$, diferencialmente sensibles a la metilación, permite una aproximación al estudio epigenético de dicha región. El estudio simultáneo de aspectos genéticos y epigenéticos en el promotor del gen PTGDR ha comenzado a cobrar importancia a raíz de un novedoso estudio de nuestro grupo en el que se introdujeron análisis epigenéticos en el asma [233]. En aquel trabajo se detectó un patrón de metilación significativamente diferente en los controles que en individuos afectados de asma, en los cuales se observó que el promotor de PTGDR se encontraba en un estado de hipometilación. Del mismo modo, y en la línea de ese resultado, se registró un aumento en la expresión de PTGDR mediante el análisis del ARNm de las células B de dichos pacientes. Como enfermedad multifactorial, el asma se caracteriza por interacciones entre genes y factores ambientales, por lo que es razonable pensar que la conexión entre ambos puedan ser determinadas alteraciones epigenéticas en las regiones promotoras [148, 233]. La aproximación metodológica que proponemos podría resultar útil en el diseño de un abordaje epigenético para el estudio de dicha región.

\section{POLíMORFíSM@ PTGDR - 197T>C}

De forma individual, hemos encontrado que el polimorfismo $-197 \mathrm{~T}>\mathrm{C}$ de PTGDR (rs11157907) se asocia significativamente con el asma, lo cual coincide con los resultados descritos en otros estudios anteriores realizados en población caucásica [206, 207]. No obstante existe cierta controversia a este respecto, puesto que estos hallazgos no han sido replicados en otras poblaciones en que se ha estudiado la asociación de dicha variante de PTGDR con el asma [151, 204, 209, 234]. También hemos encontrado diferencias significativas en la 
distribución del genotipo heterocigoto (TC) en los pacientes con asma, en especial aquellos con asma intermitente $y$ en aquellos que presentaban antecedentes familiares de asma, con un poder estadístico que superó el 75\% en ambos casos, aunque con unas FPRP de $27 \%$ para el caso de asma intermitente y $44,5 \%$ para los antecedentes familiares. Por otro lado, hay que recordar que no se cumplió el equilibrio de Hardy-Weinberg $(p=0,0008)$ en la distribución de las frecuencias genotípicas en el grupo control. Por ello, para confirmar dicha asociación se repitió el estudio en en más del $80 \%$ de las muestras, obteniendo una concordancia total en todos los casos. Este fenómeno de incumplimiento del equilibrio ha sido identificado en otros estudios y una vez descartados los problemas metodológicos (como se hizo en nuestro caso), se puede explicar por la propia asociación de la variante a la patología.

A partir del análisis multivariante se confirmó la asociación de la variante -197 en homocigosis (CC) con la ausencia de asma y, en particular, asma atópica, si bien no se alcanzó poder estadístico suficiente en ninguno de los dos casos. Finalmente, el hecho de que este polimorfismo se asocie a la patología asmática sólo cuando está presente en heterocigosis ha sido descrito anteriormente para otros SNP de genes que codifican receptores y puede reflejar un distinto comportamiento del receptor cuando la secuencia proteica mutada se expresa en heterocigosis respecto a su expresión en homocigosis.

\section{POLİMORFÍSMOPTGDR - A41C >T}

El polimorfismo PTGDR -441 (rs803010), se produce por el cambio de citosina por timina en dicho punto de la región promotora de PTGDR. En este estudio, se ha encontrado la asociación de este polimorfismo en los pacientes con asma y poliposis nasosinusal, en el que resultaron estadísticamente 
significativas las diferencias en las frecuencias alélicas entre dicho grupo de pacientes y el grupo control, mientras que en el ámbito genotípico no se observaron diferencias significativas. Cabe destacar un aparente efecto protector de la variante PTGDR -441 según el modelo de herencia dominante respecto a la presencia de poliposis concomitante a la patología asmática; sin embargo, el escaso poder estadístico obtenido no permite aseverar este resultado.

En trabajos anteriores, concretamente en una población de americanos de raza blanca, se ha descrito una asociación significativa de los genotipos portadores de una o más copias del alelo T de este polimorfismo PTGDR -441 con un mayor riesgo de padecer asma [203]. Estos datos son también controvertidos la asociación no se encontró en una segunda población de americanos africanos que se analizó en este mismo trabajo [203] o en otros estudios realizados en distintas poblaciones étnicas [204-209, 234].

\section{POLíMORFÍSMOPTGDR $-549 \mathrm{~T}>\mathrm{C}$}

Este polimorfismo, localizado a 549 pb del inicio de la transcripción de PTGDR (rs8004654), supone el cambio de una timina por una citosina en este punto de la región promotora. Cabe destacar la elevada frecuencia del alelo $\mathrm{C}$ en la población control de nuestro trabajo $(0,51)$ y en otras poblaciones en las que se ha descrito [203]. En este estudio se ha asociado de forma individual con la sensibilización conjunta a ácaros y pólenes, tanto a nivel alélico como genotípico. La presencia mayoritaria del genotipo CC en estos pacientes respecto a los controles resultó estadísticamente significativa, aunque con escaso poder estadístico. Igualmente, la diferencia entre la frecuencia del alelo C en estos individuos y en los controles fue estadísticamente significativa, más concretamente con un modelo dominante de herencia para esta variante, debido 
a las diferencias estadísticamente significativas halladas al comparar los controles y los pacientes con pruebas cutáneas positivas a ambos grupos de aeroalérgenos, ácaros y pólenes.

En estudios previos se ha descrito la asociación tanto del alelo $\mathrm{C}$ como de los genotipos portadores del mismo con un riesgo superior de presentar asma, en distintas poblaciones [203], aunque otros trabajos no han podido replicar dichos resultados [204-207, 209, 234].

\section{POLÍMORFÍSM@ PTGDR $-613 C>T$}

El cambio de citosina por timina correspondiente al polimorfismo -613 de PTGDR (rs34236606) fue descrito por primera vez por nuestro grupo [207] observando su asociación con asma en una población infantil. La frecuencia del genotipo CT del polimorfismo -613 fue superior en los controles que en los niños con asma. Previamente, esta misma variante había sido evaluada en adultos en un estudio de asociación de SNP de genes de los receptores de prostanoides, como PTGDR y el asma inducida por aspirina; sin que se observara una asociación significativa con dicha patología [235].

En este trabajo se han detectado diferencias estadísticamente significativas en la distribución del genotipo heterocigoto (CT) en los pacientes con asma y sensibilización a pólenes, ácaros o a ambos; en todos ellos el genotipo CT se observó en mayor proporción en los pacientes que en los controles. Estas asociaciones fueron confirmadas en el estudio multivariante. Sin embargo, el poder estadístico fue escaso. La diferente asociación en el asma del adulto respecto del asma infantil podría estar relacionada con las distintas características del asma infantil respecto de las del adulto [236]. El asma se ha 
considerado en muchas ocasiones como una enfermedad única desde el punto de vista genético; no obstante, Strachan y cols a, partir del análisis de los resultados genéticos del estudio Gabriel, sugieren que el asma infantil puede ser biológicamente distinta a la desarrollada durante la edad adulta identificando asociaciones diferenciales con los perfiles genéticos [237].

Del mismo modo ha resultado estadísticamente significativa la diferencia entre la frecuencia del alelo $T$ en pacientes y controles, apuntando de nuevo a la asociación de esta variante con el fenotipo atópico. Se observó una mayor presencia del alelo $\mathrm{T}$ en los pacientes con asma atópica, en particular con sensibilización a pólenes, ácaros o a ambos. Para el modelo de herencia dominante el valor del poder estadístico de la asociación fue del 77,6\% y FPRP 5,1\% para la asociación con asma atópica por ácaros y pólenes con una probabilidad a priori de asociación con la patología del 10\%. La inclusión del grupo de pacientes con PC positivas frente a neumoalérgenos que no han desarrollado asma ha permitido identificar que la asociación del SNP -613 se mantiene e incluso mejora con este grupo orientando la asociación génica hacia la sensibilización más que al mero desarrollo de asma. Esto estaría reforzado por el hecho de que no se observa asociación en el asma no alérgica.

\section{ESTVDIO DE HAPLOTİPOS}

A partir del estudio de haplotipos de PTGDR se detectó una mayor frecuencia de los haplotipos TCCTG (-613/-549/-441/-197/-95) y TCCT (-613/ -549/-441/-197) en los pacientes asmáticos con sensibilización simultánea a ácaros y pólenes en comparación con el grupo control. Los niveles de significación de las asociaciones de la combinación haplotípica TCCTG han sido similares respecto del haplotipo que excluye el polimorfismo $-95 \mathrm{G}>\mathrm{T}$. El valor del 
poder estadístico para TCCT ha sido del $78,1 \%$ y FPRP del $5,1 \%$ con una probabilidad a priori de asociación con la patología del 10\%. Para TCCTG si embargo el poder estadístico no superó el $75 \%$ y el FPRP fue del 10,5\% con una probabilidad a priori de asociación con la patología del 10\%.

Los resultados de asociación del haplotipo TCCT son de nuevo distintos de los descritos en una población infantil de origen caucásico en la cual se observó una frecuencia de TCCT superior en los controles que en los pacientes de asma [207]. Se ponen así nuevamente de manifiesto las diferencias existentes entre el asma en la infancia y en el individuo adulto.

También hemos observado un cierto efecto protector del haplotipo CTTTG (observado más frecuentemente en los controles que en los pacientes con asma y poliposis (poder estadístico del $94,1 \%$ y FPRP del $22 \%$ con una probabilidad a priori de asociación con la patología del 10\%). En este caso no se dispone de referencias anteriores similares en este grupo concreto de pacientes, sin embargo este haplotipo contiene la combinación TTT (-549/-441/-197), caracterizada por una baja eficacia de transcripción de PTGDR, y, por tanto, menores niveles de expresión del receptor [203].

Finalmente, en relación con la combinación haplotípica TCT (-549/-441/ -197), descrita por suponer una baja eficacia de transcripción del gen de PTGDR [203], se ha detectado una mayor frecuencia del haplotipo CTCTG, portador de la citada combinación, en los controles que en los pacientes con asma atópica.

Se ha determinado una asociación estadísticamente significativa del haplotipo CTCTG con la tríada de la aspirina, aunque el poder de esta asociación ha sido débil por lo que sería necesario confirmar este hallazgo con mayor número de pacientes. De cualquier forma, es importante considerar que la conjunción de la patología asmática con la intolerancia a los antiinflamatorios no 
esteroideos y la poliposis nasal se considera una entidad distinta, caracterizada por el desarrollo de una crisis asmática, generalmente grave tras la ingestión de antiinflamatorios no esteroideos (AINE), y que suele ir acompañada de rinorrea, inyección conjuntival. Generalmente, la congestión nasal evoluciona y estos pacientes desarrollan poliposis nasal [3]. Pese a que no se conocen exactamente los mecanismos fisiopatológicos subyacentes a esta enfermedad, se manejan distintas hipótesis, como la relacionada con las modificaciones en el metabolismo del ácido araquidónico causadas por la aspirina y otros AINE. La inhibición de las ciclooxigenasas por estos fármacos potenciaría la metabolización del ácido araquidónico por la vía de la 5-lipooxigenasa y con ello la síntesis de leucotrienos cisteinílicos. Se han encontrado polimorfismos en el gen de la sintasa de LTC4 en gran parte de los pacientes afectados por esta patología [238]. De hecho han sido relativamente pocos los estudios que han analizado los posibles efectos de los polimorfismos de los genes de los receptores de prostanoides en el desarrollo del asma inducida por aspirina. En relación con PTGDR, no se ha descrito la asociación de sus polimorfismos con esta patología [235].

\section{ESTVDíO DE DíPLOTíPOS}

A partir del estudio de diplotipos se han observado numerosas asociaciones génicas.

Por un lado, se han detectado diferencias significativas en la distribución del diplotipo CCCTG/CCCCG (-613CC/-549CC/-441CC/-197TC/-95GG) en los pacientes con asma, en especial con asma intermitente $y$, con un poder estadístico algo menor, con el asma atópica y en los pacientes con antecedentes familiares de asma. La asociación del diplotipo CCCTG/CCCCG con una amplia 
variedad de fenotipos de la enfermedad asmática se enmarca en la línea de los resultados aportados por anteriores trabajos publicados, ya que se trata de la combinación de los haplotipos CCT y CCC, caracterizados por ser los dos haplotipos responsables de una mayor expresión de PTGDR a través de una superior eficacia de transcripción génica [203]. Del mismo modo, se ha asociado el diplotipo CCT/CCC con asma y asma atópica en población caucásica adulta [206], así como en población infantil también de origen caucásico se ha asociado la combinación CCCT/CCCC con el asma [207]. Como ya apuntaban estos trabajos, es importante remarcar el carácter inequívoco de esta combinación diplotípica portadora de todos los genotipos en homocigosis excepto uno, la variante -197 que se encuentra en heterocigosis.

Sin embargo, el diplotipo CCCC/CCCC, portador de dos copias del haplotipo CCC, ha resultado más frecuente en la población control que en los pacientes con asma, y asma atópica en particular. El haplotipo CCC se ha asociado al asma y se ha detectado como de mayor eficiencia transcripcional, sin embargo su comportamiento en homocigosis parece ser diferente. Esta situación puede deberse al fenómeno comentado anteriormente en relación con el SNP -197, que determina la diferencia entre el diplotipo CCCT/CCCC y el diplotipo CCCC/CCCC y podría estar condicionando un distinto comportamiento del receptor, según se encuentre en homocigosis o en heterocigosis. No hay estudios de eficiencia transcripcional que permitan por el momento constatar el comportamiento de los diplotipos de PTGDR in vitro.

La distribución de otras combinaciones diplotípicas entre los controles y los distintos grupos de pacientes también ha resultado estadísticamente significativa. Entre ellas, el diplotipo CCCCG/CTCTG resultó más frecuente en los pacientes con asma no atópica que en aquellos con asma atópica, con un poder estadístico de $77,6 \%$ y un FPRP del $24 \%$ mientras que el diplotipo 
CTCTG/TCCTG se asoció con la tríada de la aspirina, en este caso el poder fue del $72,4 \%$ y FPRP del $11,3 \%$ (con una probabilidad a priori de asociación con la patología del $10 \%)$. Llama la atención dicho resultado, puesto que tal y como se ha descrito anteriormente en este trabajo se detectó la asociación del haplotipo CTCTG con la tríada de la aspirina. La asociación de una determinada combinación diplotípica con estos 3 grupos de pacientes podría estar poniendo de manifiesto cierto componente genético que comparten, y que podría estar participando en los mecanismos fisiopatólogicos del asma y la presencia de intolerancia a AINE y/o poliposis.

\section{CONSIDERACIONES DE LOS ESTVDIOS DE ASOCIACiÓN}

Como se ha comentado a lo largo de esta discusión, existe cierta controversia entre los estudios de asociación de las variantes de PTGDR y la patología asmática; en ocasiones, los resultados descritos en una determinada población no han podido ser replicados en otras poblaciones. Esta situación se planteó explícitamente en un metanálisis que consideraba los estudios de asociación genética realizados en los genes relacionados con la prostaglandina $D_{2}$, entre ellos PTGDR, del cual se citaban 3 de los polimorfismos analizados en este trabajo, $-549 \mathrm{~T}>\mathrm{C},-441 \mathrm{C}>\mathrm{T}$ y $-197 \mathrm{~T}>\mathrm{C}$ [171]. Los haplotipos resultantes de la combinación de estas variantes presentan frecuencias similares entre caucasianos, afroamericanos y portorriqueños, y podrían constituir un grupo en el cual han sido descritas varias asociaciones de PTGDR con el asma y fenotipos relacionados. Mientras que en un segundo grupo formado por asiáticos y mejicanos, con frecuencias similares de estos haplotipos, PTGDR no sería un gen candidato para el asma [171]. 
Sin embargo, las causas de estas discordancias no se limitan al factor étnico, ya que en estos estudios son fundamentales las medidas de control de calidad así como los criterios de selecciónl. Muchas son las causas que podrían explicar este fenómeno, entre ellas la distinta caracterización de los fenotipos en los grupos de estudio, incluyendo en este aspecto los criterios de selección de los grupos control. Del mismo modo, los criterios de inclusión de los pacientes varían entre los distintos estudios siendo el asma un grupo tan heterogéneo los criterios de inclusión deben estar muy bien especificados.

Otro factor muy importante que es necesario tener en cuenta es el contexto génico en el que se producen dichas variaciones. De ahí la enorme importancia de realizar estudios que consideren tanto los haplotipos en un mismo gen, como las posibles combinaciones de polimorfismos en distintos genes. El principal problema de los estudios de haplotipos e interacciones se centra en el análisis de los datos. Los estudios de haplotipos requieren de la aplicación de complejos algoritmos para la deducción de la combinación en una misma secuencia. Además, los análisis de interacciones génicas han de considerar la complejidad de las combinaciones, y es muy importante el rigor en los estudios estadísticos, a veces realizados con criterios de significación poco estrictos. Se precisa la aplicación de sistemas de control estadístico que minimicen el error del tipo I, proporcionen información sobre las probabilidades de detectar resultados espurios o sobre el propio poder estadístico de las pruebas aplicadas. Por otro lado, los estudios estadísticos requieren pruebas complejas basadas en el análisis multivariante que permitan el estudio simultáneo de las variables generadas sin las limitaciones de los clásicos estudios bivariantes. Todo ello hace necesario el empleo de programas de Bioinformática de gran potencia y rigor en el manejo de los datos que proporcionen información fiable para el correcto análisis de los resultados. En este trabajo se han considerado con especial atención todos estos aspectos, los criterios de selección han sido 
estrictos, así como los controles de calidad del análisis estadístico mediante la probabilidad de emitir falsos positivos (FPRP), el poder estadístico y la valoración del potencial efecto de las covariables a través del análisis multivariante y, en todo momento, en el trabajo del laboratorio se ha seguido la guía de buenas prácticas en el laboratorio de la EMQN [214].

En relación a esto, es necesario mencionar la diferencia de edad entre los pacientes y el grupo control que ha supuesto la inclusión de la edad como variable continua en los modelos de regresión logística. Finalmente, muchas veces el problema de estos trabajos reside en que están basados únicamente en aspectos descriptivos. La definición, además, de los posibles efectos funcionales de las variantes génicas proporciona una valiosa información con la que contrastar los resultados de asociación genética, y así lo hemos pretendido en este trabajo.

\subsection{ESTVDIO FVNCIONAL DEL PROMOTOR DE PTGDR}

Uno de los aspectos que caracteriza a las enfermedades inflamatorias del tracto respiratorio, como el asma, es el incremento de la expresión de múltiples proteínas, tales como citocinas, moléculas de adhesión celular, enzimas y receptores implicados en el proceso inflamatorio. Adicionalmente, la regulación transcripcional de la expresión de los genes que codifican estas proteínas, a través de la unión de factores de transcripción entre otros mecanismos, podría desempeñar un papel crucial en la fisiopatología y el desarrollo de estas enfermedades inflamatorias crónicas [76]. Por otro lado, los polimorfismos asociados con el asma parecen tener ciertas consecuencias más allá de cambios en la secuencia de las proteínas, en concreto los presentes en las regiones promotoras de los genes que pueden ejercer un determinado efecto en 
la expresión de los mismos. Sin embargo, no siempre es tarea fácil determinar los mecanismos exactos mediante los cuales las variantes génicas afectan a la expresión celular de un determinado gen en el contexto patológico.

En esta línea, y respecto al posible efecto de las variantes de la región promotora de PTGDR, han sido identificadas determinadas combinaciones haplotípicas de ciertos polimorfismos con capacidad para incrementar los niveles de unión de los factores de transcripción y con ello la expresión de este receptor. Tal y como se ha comentado anteriormente, en la bibliografía se ha descrito una mayor eficacia transcripcional y, por tanto, niveles de expresión superiores de este receptor de la $\mathrm{PGD}_{2}$ en células transfectadas con la combinación haplotípica CCC (-549/-441/-197) [203]. Por el contrario, el haplotipo TCT resultó el menos eficiente a nivel transcripcional. Mientras que las diferencias entre los haplotipos CCC y TCT fueron muy marcadas, otras combinaciones analizadas quedaron en una situación intermedia, como CCT y TTT, de mayor a menor eficacia transcripcional respectivamente [203]. Sin embargo estas diferencias transcripcionales se basan en estudios in vitro en los que se empleó como activador transcripcional C/EBP $\beta$. Nuestro grupo ha identificado que la presencia del SNP -613 modifica las características de unión del factor de transcripción C/EBP a la región promotora de PTGDR, con lo que los resultados de eficacia trancripcional estarían condicionados a la situación de dicho SNP en las construcciones empleadas por Oguma y cols en sus estudios. Estos resultados [203], Ilevaron a plantear que los haplotipos responsables de una mayor expresión de PTGDR se asociarían con un mayor riesgo de padecer asma a raíz de una mayor estimulación de las células del epitelio respiratorio para producir quimiocinas como CCL22 (MDC: Macrophage-derived chemokine ) o CCL17 (TARC: Thymus and activation-regulated chemokine), lo que se traduciría en una capacidad potenciada de reclutar células Th2 que expresan el receptor CCR4, 
por el cual son atraídas hacia estos ligandos. Por otro lado, considerando la función de PTGDR de promover la supervivencia de los eosinófilos en el proceso asmático, una mayor expresión de dicho receptor se traduciría también en el mantenimiento de la eosinofilia en las vías respiratorias [196] (figura 71).
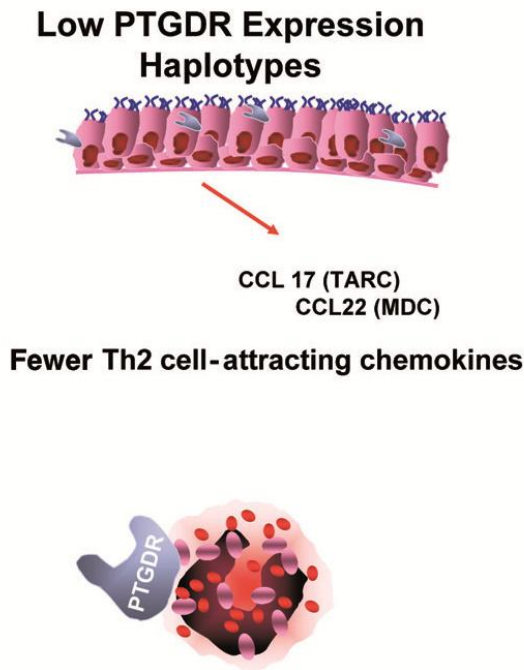

More Apoptosis of eosinophils
High PTGDR Expression Haplotypes

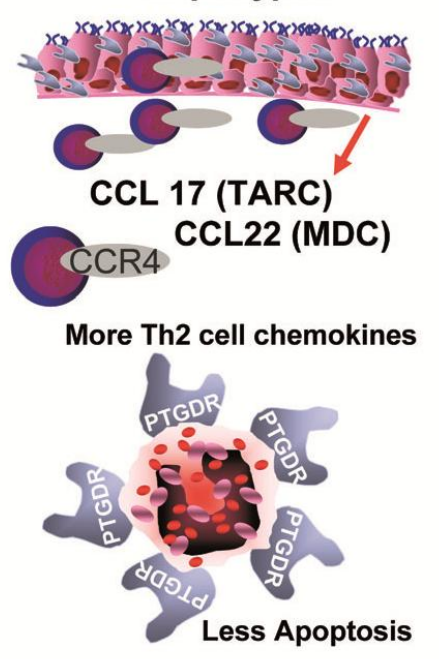

Figura 71. Relación entre las combinaciones haplotípicas de PTGDR y la susceptibilidad a padecer asma [196].

Del mismo modo, mediante ensayos de retardo en gel, una variante de estos conocida como supershift, y ensayos de inmunoprecipitación de cromatina, se han descrito distintos cambios en la unión de los factores de transcripción C/EBP $\beta$, y miembros de las familias $S p$ y GATA a la región promotora de PTGDR en función de la presencia de las variantes $-197 \mathrm{~T}>\mathrm{C},-441 \mathrm{C}>\mathrm{T}$ y -549T>C [203]. Estas proteínas de unión al ADN promueven la transcripción del gen PTGDR, y la alteración de su afinidad por cambios en su región promotora explicaría una menor tasa de transcripción y por tanto de expresión de este receptor [203]. 
Estos resultados y los obtenidos hasta el momento sobre la presencia de los polimorfismos, las distintas combinaciones haplotípicas y sobre la asociación de los mismos con el fenotipo asmático han sido el punto de partida para el diseño de un estudio funcional de dicha región promotora, con el fin de determinar los mecanismos moleculares que controlan la expresión del gen PTGDR, y que por otro lado parece estar ligada al desarrollode la enfermedad.

\section{ENSAY@S DE RETARDO EN GEL}

Mediante los ensayos de retardo en gel realizados en este trabajo se han observado cambios en los patrones de unión de las proteínas nucleares a la región promotora de $P T G D R$, principalmente relacionados con el polimorfismo $-613 \mathrm{C}>\mathrm{T}$. Estos resultados son especialmente interesantes, dado que hasta la fecha no habían sido descritos para esta variante, teniendo en cuenta la asociación que este polimorfismo ha presentado con el fenotipo atópico a partir del estudio de casos y controles realizado. Uno de los aspectos relacionados con estas proteínas de unión a las regiones reguladoras del ADN es su capacidad de interaccionar entre ellas, formando desde dímeros hasta complejos proteicos, lo que, a su vez, puede suponer una inhibición o potenciación de la actividad transcripcional [76]. Del mismo modo, es importante considerar que la activación de los factores de transcripción en ocasiones se produce a través de cascadas de transmisión de señales intracelulares o por la unión de un ligando (o ligandos) del cual dependen para su interacción con el ADN, como en el caso del receptor de glucocorticoides [178]. Por tanto, el hecho de que en el resto de los polimorfismos analizados $(-549 \mathrm{~T}>\mathrm{C},-441 \mathrm{C}>\mathrm{T},-197 \mathrm{~T}>\mathrm{C}$ y $-95 \mathrm{G}>\mathrm{T})$ no se describa la unión diferencial de factores de transcripción en función de la presencia de la variante, no implica necesariamente que dicha unión diferencial no exista, sino más bien que con esta aproximación experimental puede no 
haberse detectado teniendo en cuenta las condiciones puramente experimentales que pueden hacer que los resultados obtenidos sean en parte dependientes del conjunto de las condiciones del ensayo. Una vez identificado un distinto patrón de unión al ADN en función de la presencia del SNP -613C>T, nos planteamos la posibilidad de abordar la posible identificación de los complejos de unión diferenciales, en concreto determinar la composición proteica de estos complejos.

\section{ANÁLISSiS IN SÍLiCO DEL PROMOTOR DE PTGDR E} IDENTíFiCACí̂́N DE LOS COMPLEJOS ADN:PROTEÍNA

El primer abordaje planteado para la identificación proteica fue la aproximación mediante algoritmos informáticos. Uno de los abordajes bioinformáticos para establecer las secuencias de unión de los factores de transcripción se realiza mediante matrices de peso posicional, como el empleado por el programa EIDorado. Dichas matrices están formadas por las bases nitrogenadas de ADN ( $A, T, G$ y $C$ ) y el conjunto de secuencias de unión conocidas a un determinado factor de transcripción. Los valores de la matriz, que representan la contribución de cada base nitrogenada a la energía de unión entre el ADN y la proteína (figura 72), se establecen siguiendo distintos métodos. Finalmente es necesario establecer unos límites respecto a estas puntuaciones de la matriz. Los puntos de corte establecidos permitirán establecer una serie de resultados falsos positivos y negativos [239]. En concreto, el programa EIDorado identifica sitios potenciales de unión a factores de transcripción en las secuencias de nucleótidos a partir de grandes bibliotecas de matrices de peso. Mediante el concepto de familias de matrices y gracias a la optimización de los 
umbrales se presenta como un programa capaz de proporcionar resultados no redundantes, evitando al máximo los falsos positivos [240].

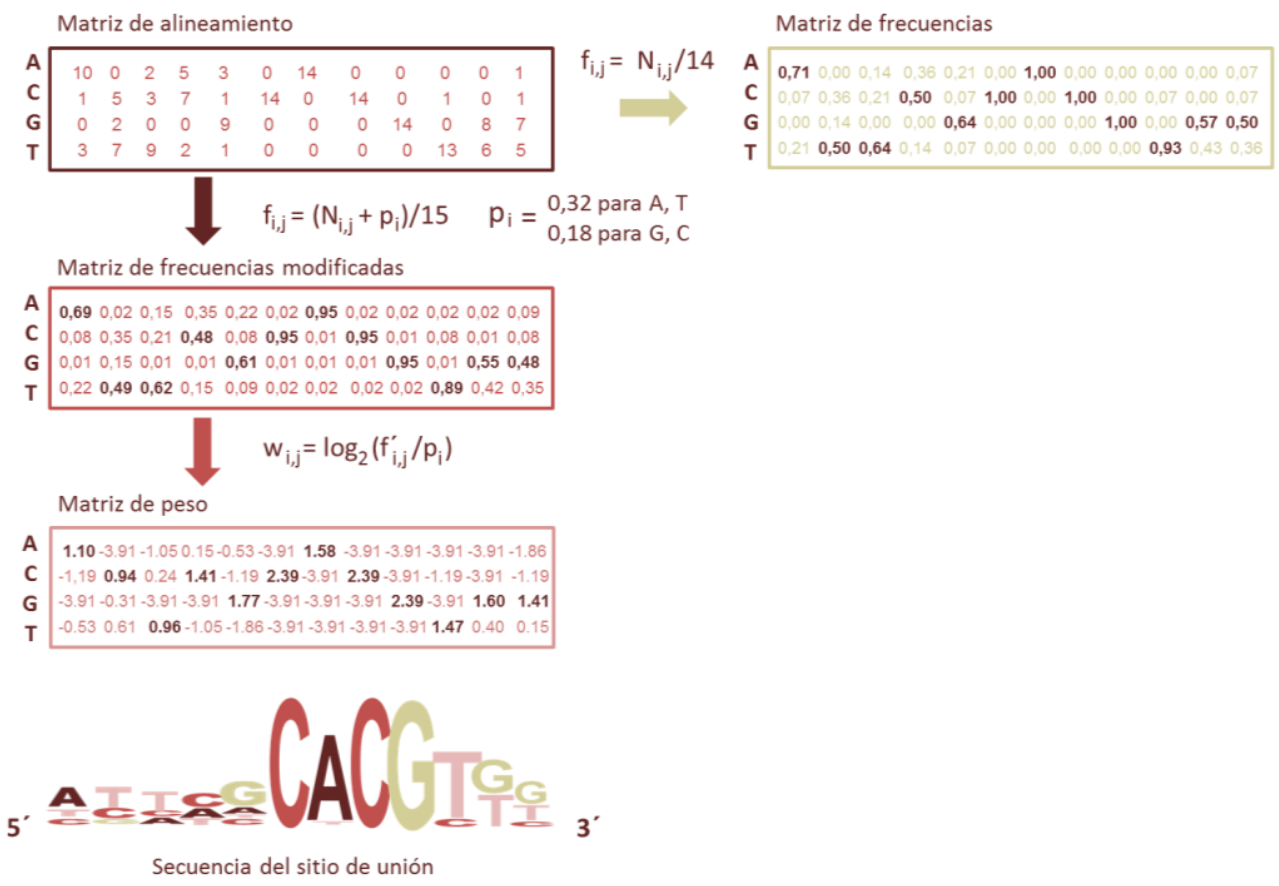

Figura 72. Representación de la matriz de los sitios de unión de un determinado factor de transcripción [239].

A partir del análisis in silico de la región promotora de PTGDR se han planteado diversos factores de transcripción cuya afinidad de unión se vería alterada en función de las variantes de la región promotora. El caso de la familia Sp, se describe la interacción de Sp2 con la región en torno al polimorfismo 197T>C, y tal y como planteaba este grupo en el 2004, en presencia de timina se describe la unión de una segunda proteína o proteínas no pertenecientes a la familia Sp en torno a esta región [203], que según los resultados de los algoritmos de EIDorado que hemos aplicado podría ser E2F-1, el cual interacciona a su vez con el factor de transcrición DP1. 
Muchos factores de transcripción se caracterizan por su presencia en la mayoría de los tipos celulares, mientras que otros son más específicos de una determinada estirpe celular y determinan algunas de sus características fenotípicas [76]. En concreto la expresión de los factores E2F-1 y DP1 se produce en numerosos tejidos, sin excluir al conjunto de células de la muestra de sangre total, de la cual procede el extracto proteico empleado en este trabajo [241].

Por otro lado es necesario mencionar que la familia E2F está implicada en la activación transcripcional y participa en múltiples complejos proteicos de unión al ADN, entre ellos algunos claves en la proliferación celular; también se ha descrito su cooperación en los mecanismos de la apoptosis [242]. Aunque se piensa que los factores E2F desempañan un papel crucial en los mecanismos de transactivación por sí solos, parece necesaria la cooperación de más factores para conseguir una interacción de alta afinidad con el ADN. Este es el caso del heterodímero que constituyen los factores de transcripción E2F-1 y DP1, en el cual DP1, capaz de unirse a E2F-1 tanto in vivo como in vitro, potencia la unión de E2F-1 a sus sitios específicos en el ADN e incrementa la transactivación de los promotores que contienen dichas regiones de unión [243]. A su vez, este complejo E2F-1/DP1 puede interaccionar con la proteína del retinoblastoma en estado de hipofosforilación, el cual inhibe el dominio de transactivación de E2F-1 [244].

A partir de los resultados del western-blotting y del shift-western no ha sido posible detectar la presencia de los factores de transcripción E2F-1 ni DP1 en la mezcla proteica y, por tanto, tampoco se ha podido descartar la interacción de los mismos con la región promotora de PTGDR. Las limitaciones metodológicas en el caso de la purificación de las mismas a partir de los concatémeros, la imprecisión en el aislamiento en gel de los complejos y la consiguiente escasez 
de muestra para el análisis por MALDITOF/TOF han sido los principales problemas, sin embargo la identificación de las proteínas con motivos en dedos de zinc que se comentarán posteriormente.

Por otro lado, cabe destacar el resultado de la interacción en torno al polimorfismo -549T>C del heterodímero VDR/RXR, formado por el receptor de la vitamina $D$ y el receptor del ácido retinoico, cuya unión al promotor de PTGDR, según el algoritmo de EIDorado, depende de la presencia del nucleótido conservado en dicha posición. El metabolito activo de la vitamina D se caracteriza por modular la respuesta inmune en las enfermedades autoinmunitarias con componente Th1, inhibiendo dicha respuesta y potenciando la respuesta Th2 [245]. Para ello es necesaria la interacción con su receptor VDR, y la actuación de ambos actuaria en la regulación de los genes diana, como podría ser el caso de PTGDR. La posible implicación de la vitamina D en el reclutamiento de células Th2 hacia las vías respiratorias característico del asma se estudió en un modelo animal de asma alérgica con ratones deficientes en VDR, los cuales no desarrollaron inflamación respiratoria, eosinofilia, ni hiperreactividad bronquial; a pesar de presentar elevadas concentraciones de IgE y citocinas tipo Th2 [138]. Por el contrario, la exposición a la vitamina D en los ratones control, trajo consigo mayor expresión de algunos genes relacionados con la respuesta Th2 como GATA-3 y CD23, asociados a la patología asmática. Los autores plantearon un posible papel del sistema endocrino de la vitamina $D$ en el desarrollo de la inflamación crónica que acontece en el asma a expensan de la actividad Th2 [138].

Del mismo modo, el ácido retinoico, metabolito activo de la vitamina $A$, se ha asociado a la modulación del equilibrio entre las respuestas Th1/Th2, en el mismo sentido en que lo hace la vitamina $D$, habiéndose determinado que las dietas con exceso de vitamina A promueven la respuesta de tipo Th2 [246]. En 
modelos múridos, con ratones previamente sensibilizados con ovoalbúmina (OVA) y expuestos a dietas pobres en vitamina $A$ se ha determinado una menor respuesta Th2 tras la exposición a la OVA [247]. Una de las familias de receptores nucleares del ácido retinoico es la $R X R$, los cuales, en ausencia de este ligando, producen el silenciamiento génico, mientras a partir de la interacción con él se promueve la transcripción. Son muchos los genes candidatos a ser regulados por el ácido retinoico, uno de ellos es CYP26A1, con dos sitios de unión a estos receptores en su región promotora e implicado en el metabolismo del propio ácido retinoico. Como resultado de un trabajo de Tesis Doctoral de nuestro grupo se ha descrito por primera vez la hipermetilación del promotor de CYP26A1 en pacientes con asma atópica por ácaros, con una diferencia moderada respecto al patrón de metilación de los controles [248].

PTGDR podría ser uno de los genes diana de estos receptores nucleares, VDR y RXR, ya que se ha descrito un motivo de unión en su secuencia promotora y, como se adelantaba en la introducción de este trabajo, al receptor DP1 de la prostaglandina $D_{2}$ se le atribuye una función inhibidora sobre los linfocitos Th1 [194]. El empleo de agonistas selectivos de PTGDR en linfocitos Th1 y células dendríticas que expresan en sus membranas dicho receptor inhibe la producción de citocinas Th1 como IL-12, lo cual favorece la respuesta Th2 [189, 249]. También se ha considerado esta función de DP1 en el tratamiento de las enfermedades autoinmunes relacionadas con la respuesta Th1 [166].

El análisis informático de las secuencias de unión de los factores de transcripción trae consigo una serie de limitaciones inherentes e inevitables. Se parte de que los motivos de unión no son estrictos, hay un conjunto de secuencias con las que un factor de transcripción puede interaccionar, dentro de las cuales hay posiciones concretas en las que siempre se repite la misma base, aunque suele haber alguna base que se da más frecuentemente que las demás 
(figura 72). Con la finalidad de evitar esta circunstancia y manejar más información a cerca de los factores de transcripción candidatos a interaccionar con PTGDR, se han empleado dos algoritmos de análisis de su región promotora.

El segundo algoritmo utilizado propone 2 sitios de unión para el factor C/EBPa, cuya interacción es dependiente del nucleótido presente en las posiciones -613 y -441 de la región promotora de PTGDR. En cuanto al ya citado trabajo de Oguma, se describe la interacción del factor C/EBP $\beta$ en torno a la variante $-441 \mathrm{C}>\mathrm{T}$ y en presencia de Timina [203]. Cabe destacar que, a pesar de que el polimorfismo $-613 \mathrm{C}>\mathrm{T}$ no fue descrito en este estudio, existe una secuencia de unión para C/EBP $\beta$ en torno a esta variante. Ambos factores, C/EBPa y C/EBP $\beta$ pertenecen a la familia C/EBP, denominada así por interaccionar con el motivo CCAAT presente en las regiones promotoras de muchos genes de los cuales regulan su expresión (CCAAT/enhancer binding proteins). El dominio tipo cremallera de leucina en el extremo carboxilo terminal y muy conservado en la familia, es el responsable de la dimerización y la unión al ADN de estas proteínas. Otra característica importante es su capacidad de reclutar otros factores una vez que han interaccionado con el ADN. La interacción de uno u otro miembro de esta familia con el promotor de un gen como PTGDR dependerá de determinados estímulos fisiológicos o patológicos; en el contexto inflamatorio, por ejemplo, la expresión de C/EBP $\beta$ se incrementa en diversos tipos celulares como los hepatocitos, macrófagos o células de la astroglia, mientras que se inhibe C/EBPa [250]. Por el contrario, C/EBP- $\alpha$ ha sido descrito en la producción de eosinófilos en un modelo equino de asma [233, 251]. En cualquier caso la presencia de las variantes $-613 \mathrm{~T}$ y $-441 \mathrm{~T}$ en dicha región promotora implica la pérdida y la aparición, respectivamente, de un sitio de unión para la familia C/EBP. Lo importante es que esta idea enlaza con la 
planteada anteriormente de que los individuos portadores de los haplotipos asociados a una menor expresión de PTGDR son menos susceptibles al asma por tener una menor capacidad de reclutamiento de linfocitos a las vías respiratorias $y$, por el contrario, una mayor capacidad de resolver la eosinofilia respiratoria mediante una mayor tasa de apoptosis de estas células [196]. Además, se ha descrito que la activación de C/EBPa simultánea a la del receptor de glucocorticoides, GR, podría explicar los efectos de los tratamientos con esteroides y $\beta$-adrenérgicos frente al asma, como la reducción de los niveles de citocinas inflamatorias [233].

En cuanto a la identificación de los complejos ADN:proteína, en este trabajo hemos planteado varias estrategias para identificar los complejos proteicos, entre ellas, en la purificación de los complejos ADN:proteína en torno al polimorfismo -613C>T destaca la identificación de tres proteínas con dedos de Zn2+. Si bien todas ellas presentan ratios muy bajos y no se corresponde a la propuesta por el algoritmo de EIDorado, ZNF336, todas se caracterizan por poseer motivos en dedos de Zinc característicos de las proteínas con capacidad de unión al ADN. Por otro lado, las tres poseen, además, un dominio tipo KRAB (Kruppel-associated box), el cual determina su actuación como represores de la transcripción mediada por las ARN polimerasas I, II y III [252] y en concreto ZNF224 actua como represor transcripcional mediado por metiltransferasa de Histonas. Por el momento no nos ha sido posible confirmar la presencia de una secuencia de unión para estos tres factores en torno al polimorfismo $-613 \mathrm{C}>\mathrm{T}$ de PTGDR si bien el mecanismo de unión transcripcional de estos factores se desarrolla a través de complejos multiproteicos lo que complica la identificación de los sitios de reconocimiento. 


\subsection{IMPLICACIONES EN LA TERAPIAA DEL ASMA}

En la búsqueda de nuevos agentes terapéuticos para el asma, la industria farmacéutica se ha hecho eco de las evidencias del papel de la prostaglandina $D_{2}$ y de sus receptores, PTGDR y CRTH2, como mediadores de sus efectos inflamatorios en dicha patología, entendiendo que la supresión de estos receptores tendría efectos muy positivos sobre los síntomas del asma y la función pulmonar [196]. En este sentido se ha propuesto la inhibición de la síntesis de este prostanoide a nivel de la ciclooxigenasa; sin embargo esta estrategia no resultó beneficiosa para el asma, ya que también supone la inhibición de la síntesis de $\mathrm{PGE}_{2}$, la cual inhibe la activación de los mastocitos [253] y ejerce efectos brocodilatadores [254]; sería necesaria, pues, la inhibición selectiva de la $\mathrm{PGD}_{2}[166]$.

Los datos obtenidos en modelos animales acerca de la participación de PTGDR en el proceso fisiopatológico del asma, y su asociación con la susceptibilidad a desarrollar asma en el ser humano parecen ser razones de peso, como hemos podido confirmar en este trabajo, para promover ensayos clínicos en humanos con alguno de los inhibidores disponibles, en algunos casos como agentes orales [196]. En ensayos con algunos de estos antagonistas de PTGDR, como S-5751, se ha comprobado que su administración inhibe la fase inicial de cogestión nasal en un modelo de rinitis alérgica en cobayas [198]. Sin embargo, en un estudio reciente no se ha conseguido demostrar la eficacia de otro antagonista de DP1, conocido como MK-0524 o laropiprant, en pacientes con asma ni en pacientes con rinitis alérgica [255]. En este mismo estudio, no se describió ninguna relación entre los polimorfismos de PTGDR y la respuesta al tratamiento. No obstante, estos estudios no tenían en cuenta los nuevos SNP identificados, ni importantes aspectos cómo el patrón epigenético. De cara a 
nuevos ensayos clínicos nosotros planteamos la utilidad de estratificar la población de pacientes que participan en ellos, identificando a los individuos portadores de haplotipos asociados a una mayor expresión de PTGDR y por tanto en los que se esperará registrar mayores beneficios a partir de una terapia dirigida a la inhibición de este receptor [196].

En resumen, en este trabajo se identifica la asociación de los polimorfismos de la región promotora del gen PTGDR con el asma, proporcionando combinaciones haplotípicas y diplotípicas con distinto grado de asociación y se profundiza en los mecanismos moleculares que pueden subyacer en dicha asociación a través de estudios transcripcionales que nos han permitido la identificación de SNP específicos que modifican dichos patrones trasncricionales y que podrían estar relacionados con una expresión fenotípica diferencial y, por tanto, contribuir a la caracterización de PTGDR como posible diana farmacológica. 



\section{CONCLVSIONES}

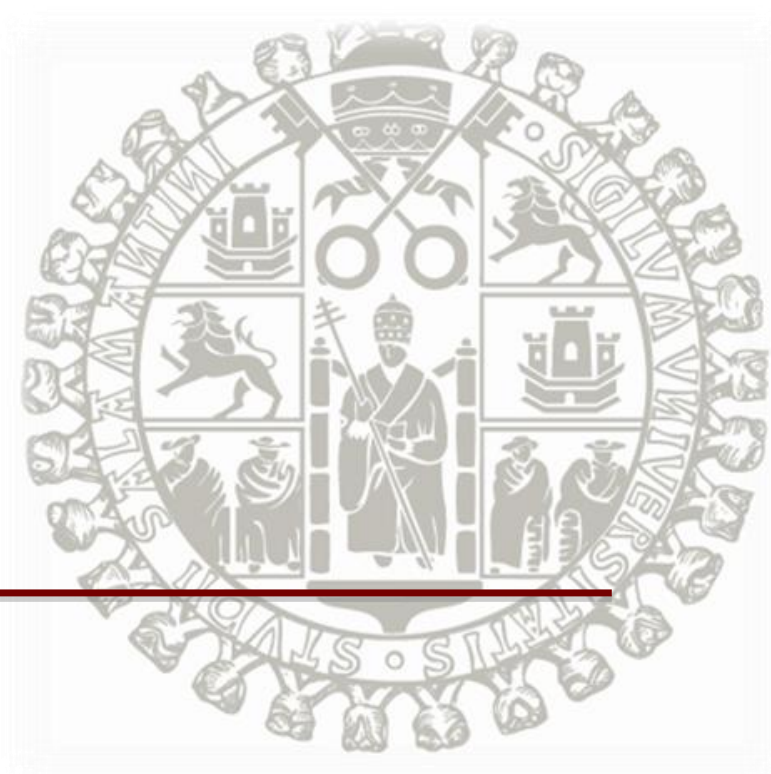





\section{CONCLVSIONES}

1. La aproximación metodológica que proponemos en este trabajo, por primera vez en la literatura, permite el análisis de la variante $-95 G>T$ en la región promotora del gen PTGDR proporcionando simultáneamente información relacionada con el patrón de metilación del gen.

2. En nuestra población, el gen del receptor de la prostaglandina $\mathrm{D}_{2}, P T G D R$, se asocia con el asma, como se infiere de la asociación identificada con el polimorfismo -197T>C y con la sensibilización alérgica, a partir de los resultados de asociación con el polimorfismo $-613 \mathrm{C}>\mathrm{T}$

3. Las combinaciones génicas portadoras de haplotipos que se han demostrado de elevada expresión para el gen PTGDR se asocian con el asma y con la presencia de sensibilización a ácaros y pólenes.

4. Los polimorfismos en el promotor de gen PTGDR inducen modificaciones en el patrón de afinidad de unión de los factores de transcripción que podrían ser responsables de cambios en la expresión del gen.

5. La caracterización de las proteínas de unión al promotor de PTGDR sugiere entre otros candidatos, al factor E2F-1, a receptores de las vitaminas A y D, 
y a varias proteínas con motivos en dedos de $\mathrm{Zn}^{2+}$, que verían alterada su interacción con dicha región en función de la presencia de las variantes génicas de dicha región.

6. Las asociaciones detectadas permiten identificar un aumento en el riesgo de padecer asma y/o atopia en los individuos portadores de algunas variantes génicas. Este riesgo podría ser debido a las modificaciones que las variantes polimórficas inducen en la unión de los factores de transcripción determinantes de la expresión del gen PTGDR, lo que refuerza la propuesta de esta región promotora como posible diana terpeútica. 
APÉNDICE

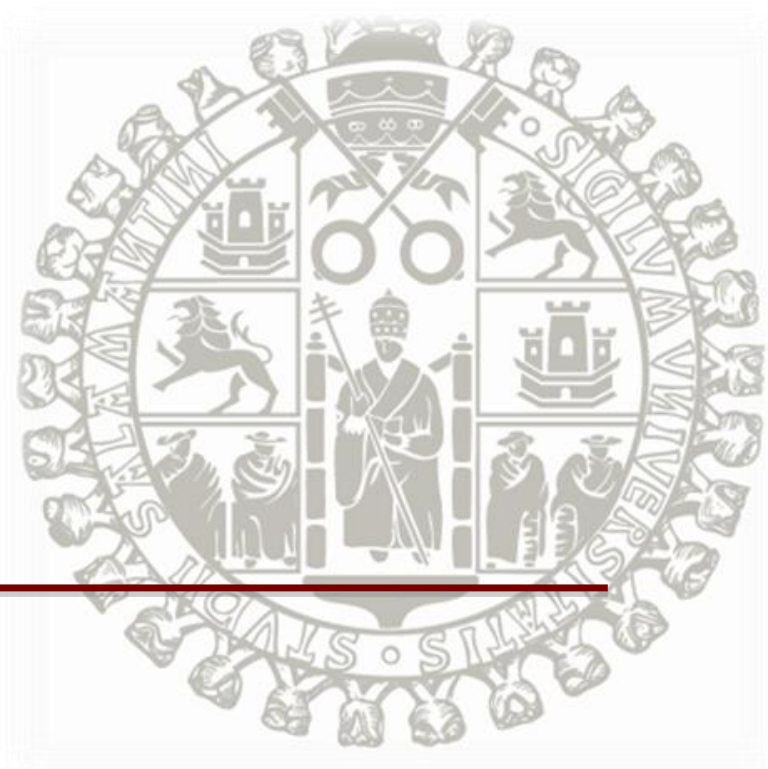





\section{APÉNDICE}

FORMVLARIீO DE RECOGIDA DE DATOS DE LOS PACIENTES.

\section{SERVICIO DE ALERGIA}

REMITIR TUBO (10 ml. EDTA - tapón morado) Y PETICIÓN AL LABORATORIO DE ALERGIA No LABORATORIO:

No SUERO:

FECHA:

CONTROL:

$\square$ NO

SI $\square$ Respiratorio

Medicamentos

NOMBRE y APELLIDOS:

$\mathrm{N}^{\circ}$ HISTORIA

EDAD

SEXO: $\mathrm{V} / \mathrm{M}$

ESTUDIO:

$\square \beta$-Lactámicos

$\square$ ASMA

$\square$ AINE-Santiago Compost. POLIPOSIS

PRUEBAS CUTÁNEAS:

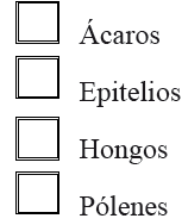

$\square$ Negativas

Pendientes Pole

ASMA:

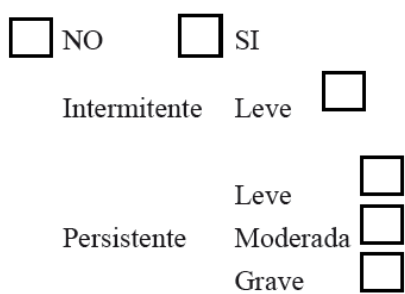

ANTECEDENTES Atopia $\square$ ler grado FAMILIARES: $\square 2$ grado MADRE ATOPIA

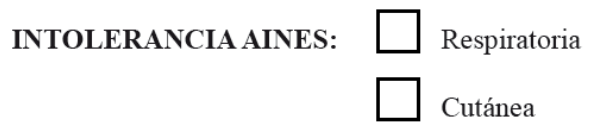
INMUNOTERAPIA:

IgE TOTAL:

OBSERVACIONES:

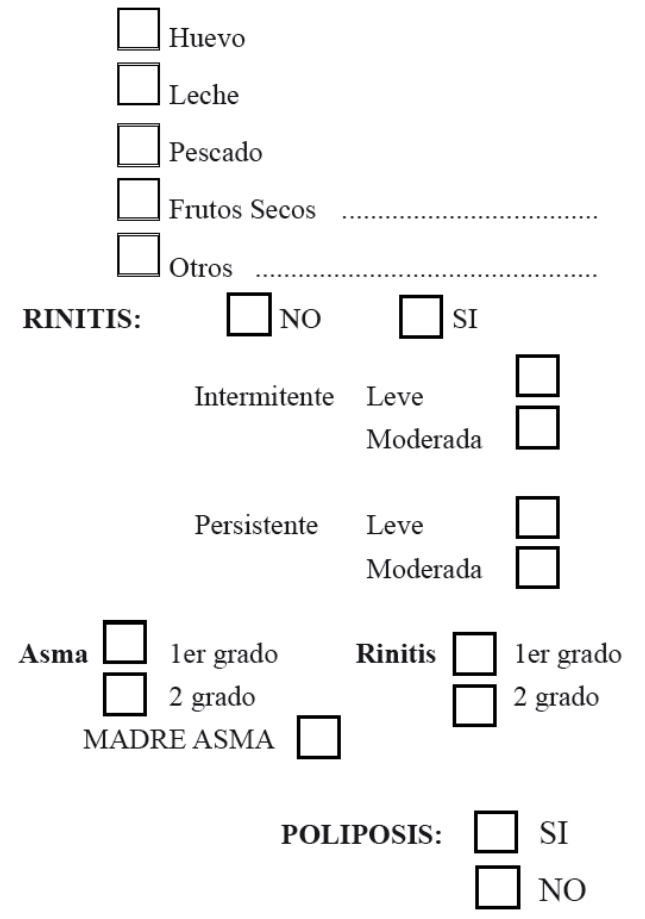




\section{BATER ÍA ESTÁNDAR DE AEROALÉRGENOS EMPLEADA EN LAS PR VEBAS \\ CVTÁNEAS (ALK -ABELLÓ, MADRİD, ESPAÑA).}

\begin{tabular}{|c|c|}
\hline \multirow{7}{*}{$\begin{array}{l}0 \\
\frac{0}{\alpha} \\
\frac{\alpha}{4}\end{array}$} & Dermatophagoides pteronisynuss \\
\hline & Dermatophagoides farinae \\
\hline & Lepidoglyphus destructor \\
\hline & Tyrophagus putrescentiae \\
\hline & Euroglyphus maynei \\
\hline & Acarus siro \\
\hline & Glycyphagus domesticus \\
\hline \multirow{10}{*}{$\begin{array}{l}\text { 岂 } \\
\text { 岂 } \\
\text { 음 }\end{array}$} & Cupressus arizonica \\
\hline & Querqus ilex \\
\hline & Platanus acerifolia \\
\hline & Cynodon dactylon \\
\hline & Phleum pratense \\
\hline & Parietaria judaica \\
\hline & Chenopodium album \\
\hline & Artemisia vulgaris \\
\hline & Plantago ovata \\
\hline & Olea euroapea \\
\hline \multirow{4}{*}{$\begin{array}{l}\text { ㅇ } \\
\text { కn } \\
\text { 오 }\end{array}$} & Alternaria alternata \\
\hline & Cladosporium herbarum \\
\hline & Penicillium notatum \\
\hline & Aspergillus fumigatus \\
\hline \multirow{6}{*}{$\begin{array}{l}\text { 음 } \\
\text { 플 } \\
\frac{E}{4}\end{array}$} & Perro \\
\hline & Gato \\
\hline & Hámster \\
\hline & Caballo \\
\hline & Conejo \\
\hline & Cucaracha \\
\hline
\end{tabular}


> RELACİ́N DE LOS OLIGONVCLEÓTİDOS EMPLEADOS EN ESTE TRABAJO.

En color blanco sobre fondo granate se representan las posiciones modificadas correspondientes a cada polimorfismo de los oligonucleótidos empleados.

\begin{tabular}{|c|c|}
\hline Cebador & Secuencia de los oligonucleótidos $\left(5^{\prime} \rightarrow 3^{\prime}\right)$ \\
\hline PTGDR F & CTCAGTTTCCTCGCCTATGC \\
\hline PTGDR R & GGAGTGAAGGCTGCGGAAG \\
\hline 613Fc & GATGACCGTGAATGCCCCAAATTG $\underline{\underline{c} G C T G A T C T A G}$ \\
\hline $613 r G$ & TCTACTAGATCAGCGECAATTTGGGGCATTCACGGT \\
\hline 613fT & GATGACCGTGAATGCCCCAAATTGI İGCTGATCTAG \\
\hline 613rA & TCTACTAGATCAGCACAATTTGGGGCATTCACGGT \\
\hline 549fT & 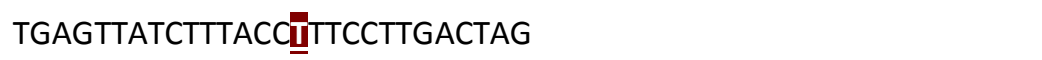 \\
\hline 549rA & TTAGCTAGTCAAGGAAAGGTAAAGATAA \\
\hline $549 \mathrm{fC}$ & TGAGTATCTTTACC重TCCTTGACTAG \\
\hline 549rG & TTAGCTAGTCAAGGAAGGGTAAAGATAA \\
\hline $441 \mathrm{fC}$ & 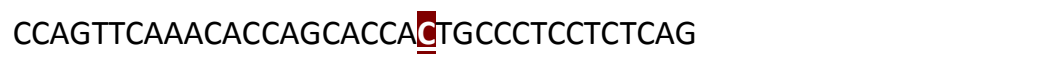 \\
\hline 441rG & CCACCTGAGAGGAGGGCA胃GGTGCTGGTGTTTGAA \\
\hline 441fT & CCAGTTCAAACACCAGCACCA产TGCCCTCCTCTCAG \\
\hline 441rA & CCACCTGAGAGGAGGGCA年GGTGCTGGTGTTTGAA \\
\hline 197fT & TGCAGAGCGTCCCGCCTCIICAAAGAGGGGT \\
\hline 197rA & TCACACCCCTCTTTGAGAGGCGGGACGCTC \\
\hline $197 \mathrm{fC}$ & TGCAGAGCGTCCCGCCTC产CAAAGAGGGGT \\
\hline 197rG & TCACACCCCTCTTTGGGAGGCGGGACGCTC \\
\hline $95 \mathrm{fG}$ & 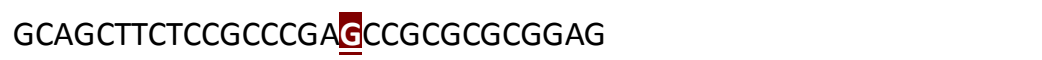 \\
\hline $95 \mathrm{rC}$ & GCAGCTCCGCGCGCGG@̈TCGGGCGGAGAAG \\
\hline 95fT & 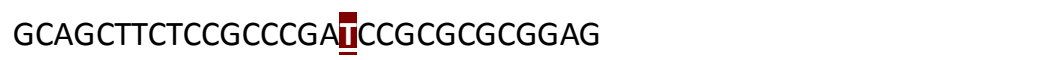 \\
\hline 95rA & GCAGCTCCGCGCGCGG望CGGGCGGAGAAG \\
\hline PH613fC & 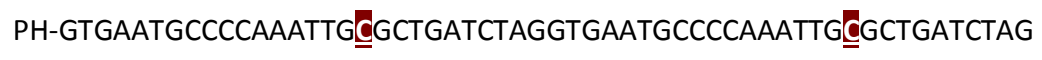 \\
\hline PH613rG & PH-TCTACTAGATCAGCGCAATTTGGGGCATTCACCTAGATCAGCGCAATTTGGGGCAT \\
\hline PH613fT & 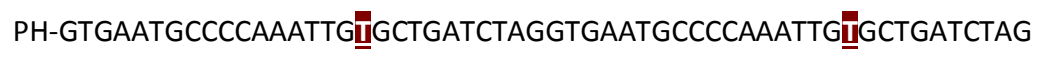 \\
\hline PH613rA & PH-TCTACTAGATCAGCACAATTTGGGGCATTCACCTAGATCAGCACAATTTGGGGCAT \\
\hline
\end{tabular}





\section{BíBLiOGRAFíA}

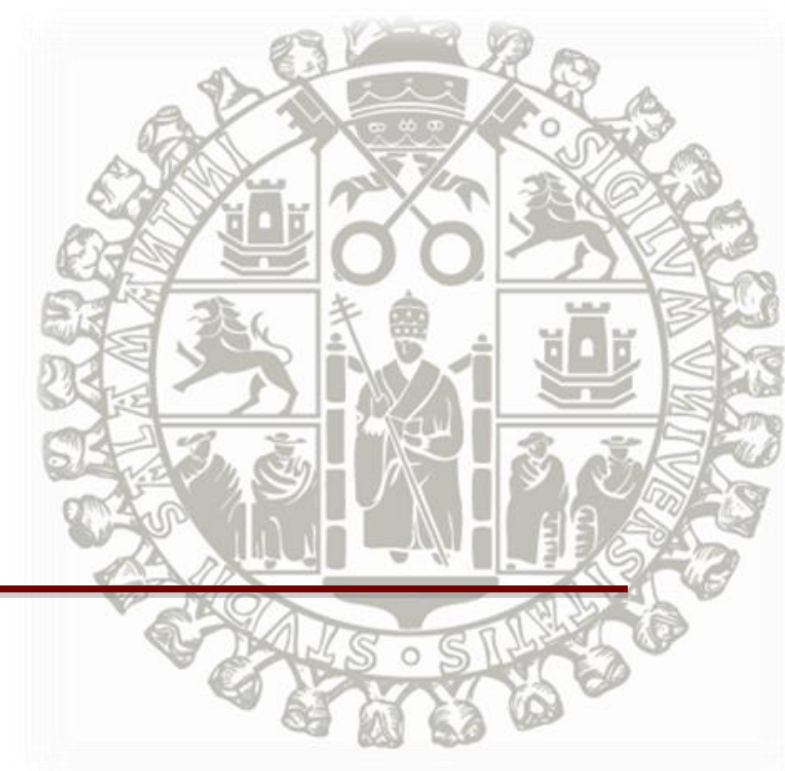





\section{BíBLiOGRAFíA}

1. Filho, P.d.A.T., Asma Bronquica/Historia da Asma, http://www.asmabronquica.com.br/medical/historia_da_asma.html, Editor 1997.

2. Salamanca, D.d.S.d.I.F.G.d.I.U.d. dicciomed.eusal.es. Diccionario médicobiológico, histórico y etimológico. 2007-2011.

3. National Heart, L.a.B.I.a.t.W.H.O., Global Strategy for Asthma Management and Prevention, Global Initiative for Asthma (GINA), 2008, http://www.ginasthma.org.

4. Zhang, J., P. Pare, and A. Sandford, Recent advances in asthma genetics. Respiratory Research, 2008. 9(1): p. 4.

5. Masoli, M., et al., The global burden of asthma: executive summary of the GINA Dissemination Committee Report. Allergy, 2004. 59(5): p. 469-478.

6. Bousquet, J., et al., The public health implications of asthma. Bulletin of the World Health Organization, 2005. 83: p. 548-554.

7. Weiss, K.B. and S.D. Sullivan, The health economics of asthma and rhinitis. I. Assessing the economic impact. J Allergy Clin Immunol, 2001. 107(1): p. 3-8.

8. ISAAC, T.I.S.o.A.a.A.i.C.S.C., Worldwide variations in the prevalence of asthma symptoms: the International Study of Asthma and Allergies in Childhood (ISAAC). European Respiratory Journal, 1998. 12(2): p. 315335. 
9. Pearce, N., et al., Worldwide trends in the prevalence of asthma symptoms: phase III of the International Study of Asthma and Allergies in Childhood (ISAAC). Thorax, 2007. 62(9): p. 758-766.

10. Yawn, B.P., Asthma screening, case identification and treatment in schoolbased programs. Curr Opin Pulm Med, 2006. 12(1): p. 23-7.

11. Hargreave, F.E., et al., Bronchial responsiveness to histamine or methacholine in asthma: measurement and clinical significance. Journal of Allergy and Clinical Immunology, 1981. 68(5): p. 347-355.

12. Sirvent J, G.P.-Y.E., Fisiopatología, diagnóstico y evaluación del paciente asmático., in Tratado de Neumología Infantil, N.a.G.P.-Y. Cobos, Editor 2003. p. $577-598$.

13. Boulet, L.P., Physiopathology of airway hyperresponsiveness. Curr Allergy Asthma Rep, 2003. 3(2): p. 166-71

14. Adkinson F, B.B., Busse W, Holgate S, Lemanske R, Simons F.,, Middleton's Allergy: Principles \& Practice. 7th Edition ed. ed2009.

15. Weiss, S.T. and B.A. Raby, Asthma genetics 2003. Hum Mol Genet, 2004. 13 Spec No 1: p. R83-9.

16. Busse, W.W., et al., Asthma. New England Journal of Medicine, 2001. 344(5): p. 350-362

17. Gern, J.E. and W.W. Busse, Relationship of viral infections to wheezing illnesses and asthma. Nat Rev Immunol, 2002. 2(2): p. 132-8.

18. Nakajima, H. and K. Takatsu, Role of cytokines in allergic airway inflammation. Int Arch Allergy Immunol, 2007. 142(4): p. 265-73. 
19. Peter, B., F.W. Andrew, and T.H. Stephen, The role of the mast cell in the pathophysiology of asthma. The Journal of allergy and clinical immunology, 2006. 117(6): p. 1277-1284.

20. Bradding, P. and S.T. Holgate, Immunopathology and human mast cell cytokines. Crit Rev Oncol Hematol, 1999. 31(2): p. 119-33.

21. Brightling, C.E., et al., The CXCL10/CXCR3 axis mediates human lung mast cell migration to asthmatic airway smooth muscle. Am J Respir Crit Care Med, 2005. 171(10): p. 1103-8.

22. Bischoff, S.C., Role of mast cells in allergic and non-allergic immune responses: comparison of human and murine data. Nat Rev Immunol, 2007. 7(2): p. 93-104.

23. Vignola, A.M., et al., Evaluation of apoptosis of eosinophils, macrophages, and $T$ lymphocytes in mucosal biopsy specimens of patients with asthma and chronic bronchitis. J Allergy Clin Immunol, 1999. 103(4): p. 563-73.

24. Rothenberg, M.E. and S.P. Hogan, The eosinophil. Annu Rev Immunol, 2006. 24: p. 147-74.

25. Wenzel, S.E., et al., Evidence That Severe Asthma Can Be Divided Pathologically into Two Inflammatory Subtypes with Distinct Physiologic and Clinical Characteristics. Am. J. Respir. Crit. Care Med., 1999. 160(3): p. 1001-1008.

26. Jacoby, D.B., R.M. Costello, and A.D. Fryer, Eosinophil recruitment to the airway nerves. J Allergy Clin Immunol, 2001. 107(2): p. 211-8.

27. Trivedi, S.G. and C.M. Lloyd, Eosinophils in the pathogenesis of allergic airways disease. Cell Mol Life Sci, 2007. 64(10): p. 1269-89.

28. Williams, T.J., The eosinophil enigma. J Clin Invest, 2004. 113(4): p. 507-9. 
29. Hamid, Q., et al., Co-expression of CD25 and CD3 in atopic allergy and asthma. Immunology, 1992. 75(4): p. 659-63.

30. Kay, A.B., The role of $T$ lymphocytes in asthma. Chem Immunol Allergy, 2006. 91 : p. 59-75.

31. Hammad, H. and B.N. Lambrecht, Dendritic cells and epithelial cells: linking innate and adaptive immunity in asthma. Nat Rev Immunol, 2008. 8(3): p. 193-204.

32. Lambrecht, B.N. and H. Hammad, The role of dendritic and epithelial cells as master regulators of allergic airway inflammation. Lancet, 2010. 376(9743): p. 835-43

33. Chung, K.F. and P.J. Barnes, Cytokines in asthma. Thorax, 1999. 54(9): p. $825-57$.

34. Ricciardolo, F.L., et al., Nitric oxide in health and disease of the respiratory system. Physiol Rev, 2004. 84(3): p. 731-65.

35. Smith, A.D. and D.R. Taylor, Is exhaled nitric oxide measurement a useful clinical test in asthma? Current Opinion in Allergy and Clinical Immunology, 2005. 5(1): p. 49-56.

36. Rozycki, H.J., P.G. Comber, and T.F. Huff, Cytokines and oxygen radicals after hyperoxia in preterm and term alveolar macrophages. Am J Physiol Lung Cell Mol Physiol, 2002. 282(6): p. L1222-8.

37. Miller, A.L. and N.W. Lukacs, Chemokine receptors: understanding their role in asthmatic disease. Immunol Allergy Clin North Am, 2004. 24(4): p. 667-83, vii.

38. Chattergoon, M.A., et al., Specific immune induction following DNA-based immunization through in vivo transfection and activation of 
macrophages/antigen-presenting cells. J Immunol, 1998. 160(12): p. 570718.

39. Peters-Golden, M., The alveolar macrophage: the forgotten cell in asthma. Am J Respir Cell Mol Biol, 2004. 31(1): p. 3-7.

40. Jatakanon, A., et al., Neutrophilic Inflammation in Severe Persistent Asthma. Am. J. Respir. Crit. Care Med., 1999. 160(5): p. 1532-1539.

41. Wenzel, SALLY E., et al., Bronchoscopic Evaluation of Severe Asthma . Persistent Inflammation Associated with High Dose Glucocorticoids. Am. J. Respir. Crit. Care Med., 1997. 156(3): p. 737-743.

42. Sur, S., et al., Sudden-onset fatal asthma. A distinct entity with few eosinophils and relatively more neutrophils in the airway submucosa? Am Rev Respir Dis, 1993. 148(3): p. 713-9.

43. Monteseirin, J., Neutrophils and asthma. J Investig Allergol Clin Immunol, 2009. 19(5): p. 340-54.

44. O'Byrne, P.M., et al., Asthma induced by cold air and its relation to nonspecific bronchial responsiveness to methacholine. Am Rev Respir Dis, 1982. 125(3): p. $281-5$.

45. O'Byrne, P.M., et al., Lung epithelial permeability: relation to nonspecific airway responsiveness. J Appl Physiol, 1984. 57(1): p. 77-84.

46. Boulet, L.-P., et al., Airway Hyperresponsiveness, Inflammation, and Subepithelial Collagen Deposition in Recently Diagnosed versus Longstanding Mild Asthma . Influence of Inhaled Corticosteroids. Am. J. Respir. Crit. Care Med., 2000. 162(4): p. 1308-1313.

47. Jeffery, P.K., Remodeling in Asthma and Chronic Obstructive Lung Disease. Am. J. Respir. Crit. Care Med., 2001. 164(10): p. S28-38. 
48. Benayoun, L., et al., Airway Structural Alterations Selectively Associated with Severe Asthma. Am. J. Respir. Crit. Care Med., 2003. 167(10): p. $1360-1368$.

49. Cho, S.H., et al., Pathological changes according to the severity of asthma. Clin Exp Allergy, 1996. 26(10): p. 1210-9.

50. Pepe, C., et al., Differences in airway remodeling between subjects with severe and moderate asthma. Journal of Allergy and Clinical Immunology, 2005. 116(3): p. 544-549.

51. de Marco, R., et al., Prognostic factors of asthma severity: A 9-year international prospective cohort study. Journal of Allergy and Clinical Immunology, 2006. 117(6): p. 1249-1256.

52. Reynold, A.P., Airway smooth muscle: An immunomodulatory cell. The Journal of allergy and clinical immunology, 2002. 110(6): p. S269-S274.

53. Bara, I., et al., Pathophysiology of bronchial smooth muscle remodelling in asthma. Eur Respir J, 2010. 36(5): p. 1174-84.

54. Bergeron, C. and L.P. Boulet, Structural changes in airway diseases: characteristics, mechanisms, consequences, and pharmacologic modulation. Chest, 2006. 129(4): p. 1068-87.

55. Makoto, H., T. Miki, and A. Nozomi, Expression of vascular endothelial growth factor, basic fibroblast growth factor, and angiogenin immunoreactivity in asthmatic airways and its relationship to angiogenesis. The Journal of allergy and clinical immunology, 2001. 107(2): p. 295-301.

56. Chetta, A., et al., Vascular endothelial growth factor up-regulation and bronchial wall remodelling in asthma. Clinical \& Experimental Allergy, 2005. 35(11): p. 1437-1442. 
57. Warner, J.O., The early life origins of asthma and related allergic disorders. Arch Dis Child, 2004. 89(2): p. 97-102.

58. Jones, C.A., J.A. Warner, and J.O. Warner, Fetal swallowing of IgE. The Lancet, 1998. 351(9119): p. 1859-1859.

59. Mudde, G.C., R. Bheekha, and C.A.F.M. Bruijnzeel-Koomen, Consequences of IgE/CD23-mediated antigen presentation in allergy. Immunology Today, 1995. 16(8): p. 380-383.

60. De Luca, G., et al., Fetal and early postnatal life roots of asthma. Journal of Maternal-Fetal and Neonatal Medicine, 2010. 23(S3): p. 80-83.

61. Liu, A.H. and S.J. Szefler., Advances in childhood asthma: Hygiene hypothesis, natural history, and management. Journal of Allergy and Clinical Immunology, 2003. 111(3, Supplement 1): p. S785-S792.

62. Paunio, M., et al., Measles History and Atopic Diseases: A PopulationBased Cross-sectional Study. JAMA, 2000. 283(3): p. 343-346.

63. Marra, F., et al., Does antibiotic exposure during infancy lead to development of asthma?: a systematic review and metaanalysis. Chest, 2006. $129(3):$ p. $610-8$.

64. Von, M., et al., Exposure to endotoxin or other bacterial components might protect against the development of atopy. Clinical \& Experimental Allergy, 2000. 30(9): p. 1230-1234.

65. Holt PG, S.P., Bjorksten B., Atopy versus infectious diseases in childhood; a question of balance. Pediatric Allergy Immunology, 1997. 8: p. 53-8.

66. Lemanske Jr, R.F., et al., Rhinovirus illnesses during infancy predict subsequent childhood wheezing. Journal of Allergy and Clinical Immunology, 2005. 116(3): p. 571-577. 
67. Sigurs, N., et al., Severe Respiratory Syncytial Virus Bronchiolitis in Infancy and Asthma and Allergy at Age 13. Am. J. Respir. Crit. Care Med., 2005. 171(2): p. 137-141.

68. Lemanske, J.R.F. and W.W. Busse, Factors underlying inception, exacerbation, and disease progression. Journal of Allergy and Clinical Immunology, 2006. 117(2, Supplement 2): p. S456-S461.

69. KRAFT, M., et al., Detection of Mycoplasma pneumoniae in the Airways of Adults with Chronic Asthma. Am. J. Respir. Crit. Care Med., 1998. 158(3): p. $998-1001$.

70. Cook, P.J., et al., Chlamydia pneumoniae and asthma. Thorax, 1998. 53(4): p. 254-259.

71. Teal, S.H., et al., Genetic pleiotropy between asthma and obesity in a community-based sample of twins. The Journal of allergy and clinical immunology, 2005. 116(6): p. 1235-1241.

72. Beuther, D.A., S.T. Weiss, and E.R. Sutherland, Obesity and Asthma. Am. J. Respir. Crit. Care Med., 2006. 174(2): p. 112-119.

73. Cottrell, L., et al., Metabolic Abnormalities in Children with Asthma. Am. J. Respir. Crit. Care Med., 2010: p. 201004-0603OC.

74. Sporik, R., et al., Exposure to house-dust mite allergen (Der $p$ I) and the development of asthma in childhood. A prospective study. N Engl J Med, 1990. 323(8): p. 502-7.

75. Gauvreau, G.M., R.M. Watson, and P.M. O'Byrne, Kinetics of allergeninduced airway eosinophilic cytokine production and airway inflammation. Am J Respir Crit Care Med, 1999. 160(2): p. 640-7. 
76. Wood, L.J., et al., Changes in bone marrow inflammatory cell progenitors after inhaled allergen in asthmatic subjects. Am J Respir Crit Care Med, 1998. 157(1): p. 99-105.

77. Sears, M.R., et al., The relative risks of sensitivity to grass pollen, house dust mite and cat dander in the development of childhood asthma. Clin Exp Allergy, 1989. 19(4): p. 419-24.

78. Cypcar, D. and R.F. Lemanske, Jr., Asthma and exercise. Clin Chest Med, 1994. 15(2): p. 351-68.

79. McFadden, E.R., Jr. and I.A. Gilbert, Exercise-induced asthma. N Engl J Med, 1994. 330(19): p. 1362-7.

80. Brannan, J.D. and J.A. Turton, The inflammatory basis of exercise-induced bronchoconstriction. Phys Sportsmed, 2010. 38(4): p. 67-73.

81. Poussel, M. and B. Chenuel, [Exercise-induced bronchoconstriction in nonasthmatic athletes]. Rev Mal Respir, 2010. 27(8): p. 898-906.

82. Millward, D.T., L.G. Tanner, and M.A. Brown, Treatment options for the management of exercise-induced asthma and bronchoconstriction. Phys Sportsmed, 2010. 38(4): p. 74-80.

83. Bellido-Casado, J., Asma y tabaco: una unión inconveniente. Archivos de Bronconeumología, 2007. 43(6): p. 340-5.

84. Sippel, J.M., et al., Associations of Smoking With Hospital-Based Care and Quality of Life in Patients With Obstructive Airway Disease*. Chest, 1999. 115(3): p. 691-696.

85. E. Prescott, P.L., and J. Vestbo, Effect of gender on hospital admissions for asthma and prevalence of self-reported asthma: a prospective study based on a sample of the general population. Copenhagen City Heart Study Group Thorax, 1997.52 (3): p. 287-289. 
86. Barnes, P.J., The cytokine network in asthma and chronic obstructive pulmonary disease. J Clin Invest, 2008. 118(11): p. 3546-56.

87. Barnes, N.C., Can Guideline-defined Asthma Control Be Achieved?: The Gaining Optimal Asthma Control Study. Am. J. Respir. Crit. Care Med., 2004. 170(8): p. 830-831.

88. D'Amato, G., et al., Urban air pollution and climate change as environmental risk factors of respiratory allergy: an update. J Investig Allergol Clin Immunol, 2010. 20(2): p. 95-102; quiz following 102.

89. Tokuyama, H., Y. Tokuyama, and K. Nakanishi, Retinoids Inhibit IL-4Dependent IgE and IgG1 Production by LPS-Stimulated Murine Splenic B Cells. Cellular Immunology, 1995. 162(1): p. 153-158.

90. Los, H., P.E. Postmus, and D.I. Boomsma, Asthma genetics and intermediate phenotypes: a review from twin studies. Twin Res, 2001. 4(2): p. 81-93.

91. Duffy, D.L., et al., Genetics of asthma and hay fever in Australian twins. Am Rev Respir Dis, 1990. 142(6 Pt 1): p. 1351-8.

92. Nieminen, M.M., J. Kaprio, and M. Koskenvuo, A population-based study of bronchial asthma in adult twin pairs. Chest, 1991. 100(1): p. 70-5.

93. Hopp, R.J., et al., Genetic analysis of allergic disease in twins. J Allergy Clin Immunol, 1984. 73(2): p. 265-70.

94. Koeppen-Schomerus, G., J. Stevenson, and R. Plomin, Genes and environment in asthma: a study of 4 year old twins. Arch Dis Child, 2001. 85(5): p. 398-400.

95. Drinkwater, H., An Address on Recent Theories and Experiments on Heredity and Inheritance: Delivered before the Denbigh and Flint Division of the British Medical Association. Br Med J, 1908. 2(2499): p. 1538-1541. 
96. Gao, P.S. and S.K. Huang, Genetic aspects of asthma. Panminerva Med, 2004. 46(2): p. 121-34.

97. Kumar, A. and B. Ghosh, Genetics of asthma: a molecular biologist perspective. Clin Mol Allergy, 2009. 7: p. 7.

98. Townley, R.G., et al., Segregation analysis of bronchial response to methacholine inhalation challenge in families with and without asthma. J Allergy Clin Immunol, 1986. 77(1 Pt 1): p. 101-7.

99. Palmer, L.J., et al., Meta-analysis for linkage to asthma and atopy in the chromosome 5q31-33 candidate region. Hum Mol Genet, 2001. 10(8): p. 891-99.

100. Vercelli, D., Discovering susceptibility genes for asthma and allergy. Nat Rev Immunol, 2008. 8(3): p. 169-82.

101. Xu, X., et al., A genomewide search for quantitative-trait loci underlying asthma. Am J Hum Genet, 2001. 69(6): p. 1271-7.

102. Dizier, M.H., et al., Genome screen for asthma and related phenotypes in the French EGEA study. Am J Respir Crit Care Med, 2000. 162(5): p. 18128.

103. Haagerup, A., et al., Asthma and atopy - a total genome scan for susceptibility genes. Allergy, 2002. 57(8): p. 680-6.

104. Wjst, M., et al., A genome-wide search for linkage to asthma. German Asthma Genetics Group. Genomics, 1999. 58(1): p. 1-8.

105. Hoffjan, S. and C. Ober, Present status on the genetic studies of asthma. Curr Opin Immunol, 2002. 14(6): p. 709-17.

106. Risch, N. and K. Merikangas, The future of genetic studies of complex human diseases. Science, 1996. 273(5281): p. 1516-7. 
107. Hoffjan, S., D. Nicolae, and C. Ober, Association studies for asthma and atopic diseases: a comprehensive review of the literature. Respir Res, 2003. 4: p. 14.

108. McCarthy, M.I., et al., Genome-wide association studies for complex traits: consensus, uncertainty and challenges. Nat Rev Genet, 2008. 9(5): p. 35669.

109. Vercelli, D. and F.D. Martinez, The Faustian bargain of genetic association studies: bigger might not be better, or at least it might not be good enough. J Allergy Clin Immunol, 2006. 117(6): p. 1303-5.

110. Tamari, M., K. Tomita, and T. Hirota, Genome-wide association studies of asthma. Allergol Int, 2011. 60(3): p. 247-52.

111. Williams, S.M., et al., Problems with genome-wide association studies. Science, 2007. 316(5833): p. 1840-2.

112. Malerba, G. and P.F. Pignatti, A review of asthma genetics: gene expression studies and recent candidates. J Appl Genet, 2005. 46(1): p. 93-104.

113. Blumenthal, M., et al., HLA-DR2, [HLA-B7, SC31, DR2], and [HLA-B8, SC01, DR3] haplotypes distinguish subjects with asthma from those with rhinitis only in ragweed pollen allergy. J Immunol, 1992. 148(2): p. 411-6.

114. Meyers, D.A., et al., Evidence for a locus regulating total serum IgE levels mapping to chromosome 5. Genomics, 1994. 23(2): p. 464-70.

115. Shirakawa, T., et al., Association between atopy and variants of the beta subunit of the high-affinity immunoglobulin E receptor. Nat Genet, 1994. $7(2)$ : p. $125-9$.

116. Cookson, W., The immunogenetics of asthma and eczema: a new focus on the epithelium. Nat Rev Immunol, 2004. 4(12): p. 978-88. 
117. Hobbs, K., et al., Interleukin-10 and transforming growth factor-beta promoter polymorphisms in allergies and asthma. Am J Respir Crit Care Med, 1998. 158(6): p. 1958-62.

118. Ying, S., et al., Lack of filaggrin expression in the human bronchial mucosa. J Allergy Clin Immunol, 2006. 118(6): p. 1386-8.

119. Palmer, C.N., et al., Common loss-of-function variants of the epidermal barrier protein filaggrin are a major predisposing factor for atopic dermatitis. Nat Genet, 2006. 38(4): p. 441-6.

120. Palmer, C.N., et al., Filaggrin null mutations are associated with increased asthma severity in children and young adults. J Allergy Clin Immunol, 2007. 120(1): p. 64-8.

121. Allen, M., et al., Positional cloning of a novel gene influencing asthma from chromosome 2q14. Nat Genet, 2003. 35(3): p. 258-63.

122. Kabesch, M., et al., Polymorphisms in eosinophil pathway genes, asthma and atopy. Allergy, 2007. 62(4): p. 423-8.

123. Basehore, M.J., et al., A comprehensive evaluation of IL4 variants in ethnically diverse populations: association of total serum IgE levels and asthma in white subjects. J Allergy Clin Immunol, 2004. 114(1): p. 80-7.

124. Vladich, F.D., et al., IL-13 R130Q, a common variant associated with allergy and asthma, enhances effector mechanisms essential for human allergic inflammation. J Clin Invest, 2005. 115(3): p. 747-54.

125. Cameron, L., et al., Th2 cell-selective enhancement of human IL13 transcription by IL13-1112C>T, a polymorphism associated with allergic inflammation. J Immunol, 2006. 177(12): p. 8633-42. 
126. Baldini, M., et al., A Polymorphism* in the $5^{\prime}$ flanking region of the CD14 gene is associated with circulating soluble CD14 levels and with total serum immunoglobulin E. Am J Respir Cell Mol Biol, 1999. 20(5): p. 976-83.

127. Walley, A.J., et al., Gene polymorphism in Netherton and common atopic disease. Nat Genet, 2001. 29(2): p. 175-8.

128. Silverman, E.K., et al., Family-based association analysis of beta2adrenergic receptor polymorphisms in the childhood asthma management program. J Allergy Clin Immunol, 2003. 112(5): p. 870-6.

129. Hall, I.P. and I. Sayers, Pharmacogenetics and asthma: false hope or new dawn? Eur Respir J, 2007. 29(6): p. 1239-45.

130. Noguchi, E., et al., Positional identification of an asthma susceptibility gene on human chromosome 5q33. Am J Respir Crit Care Med, 2005. 172(2): p. $183-8$.

131. Moffatt, M.F. and W.O. Cookson, Tumour necrosis factor haplotypes and asthma. Hum Mol Genet, 1997. 6(4): p. 551-4.

132. Shiina, T., H. Inoko, and J.K. Kulski, An update of the HLA genomic region, locus information and disease associations: 2004. Tissue Antigens, 2004. 64(6): p. 631-649.

133. Nicolae, D., et al., Fine mapping and positional candidate studies identify HLA-G as an asthma susceptibility gene on chromosome 6p21. Am J Hum Genet, 2005. 76(2): p. 349-57.

134. Laitinen, T., et al., A susceptibility locus for asthma-related traits on chromosome 7 revealed by genome-wide scan in a founder population. Nat Genet, 2001. 28(1): p. 87-91. 
135. Vendelin, J., et al., Characterization of GPRA, a novel G protein-coupled receptor related to asthma. Am J Respir Cell Mol Biol, 2005. 33(3): p. 26270.

136. Pykalainen, M., et al., Association analysis of common variants of STAT6, GATA3, and STAT4 to asthma and high serum IgE phenotypes. J Allergy Clin Immunol, 2005. 115(1): p. 80-7.

137. Brasch-Andersen, C., et al., Possible gene dosage effect of glutathione-Stransferases on atopic asthma: using real-time PCR for quantification of GSTM1 and GSTT1 gene copy numbers. Hum Mutat, 2004. 24(3): p. 20814.

138. Wittke, A., et al., Vitamin $D$ receptor-deficient mice fail to develop experimental allergic asthma. J Immunol, 2004. 173(5): p. 3432-6.

139. Zhang, Y., et al., Positional cloning of a quantitative trait locus on chromosome $13 q 14$ that influences immunoglobulin E levels and asthma. Nat Genet, 2003. 34(2): p. 181-6.

140. Mellor, J., It takes a PHD to read the histone code. Cell, 2006. 126(1): p. 22-4.

141. Mansur, A.H., et al., Linkage/association study of a locus modulating total serum IgE on chromosome 14q13-24 in families with asthma. Thorax, 2004. 59(10): p. 876-82.

142. Van Eerdewegh, P., et al., Association of the ADAM33 gene with asthma and bronchial hyperresponsiveness. Nature, 2002. 418(6896): p. 426-30.

143. Blakey, J., et al., Contribution of ADAM33 polymorphisms to the population risk of asthma. Thorax, 2005. 60(4): p. 274-6. 
144. Jongepier, H., et al., Polymorphisms of the ADAM33 gene are associated with accelerated lung function decline in asthma. Clin Exp Allergy, 2004. 34(5): p. 757-60.

145. Holgate, S.T., et al., Local genetic and environmental factors in asthma disease pathogenesis: chronicity and persistence mechanisms. Eur Respir J, 2007. 29(4): p. 793-803.

146. Howard, T.D., et al., Association of a disintegrin and metalloprotease 33 (ADAM33) gene with asthma in ethnically diverse populations. J Allergy Clin Immunol, 2003. 112(4): p. 717-22.

147. Cakebread, J.A., et al., The role of ADAM33 in the pathogenesis of asthma. Springer Semin Immunopathol, 2004. 25(3-4): p. 361-75.

148. Miller, R.L. and S.M. Ho, Environmental epigenetics and asthma: current concepts and call for studies. Am J Respir Crit Care Med, 2008. 177(6): p. 567-73.

149. Razin, A., CpG methylation, chromatin structure and gene silencing-a three-way connection. EMBO J, 1998. 17(17): p. 4905-8.

150. Szyf, M. and M.J. Meaney, Epigenetics, behaviour, and health. Allergy Asthma Clin Immunol, 2008. 4(1): p. 37-49.

151. Nightingale, K.P., L.P. O'Neill, and B.M. Turner, Histone modifications: signalling receptors and potential elements of a heritable epigenetic code. Curr Opin Genet Dev, 2006. 16(2): p. 125-36.

152. Kumar, R.K., M.P. Hitchins, and P.S. Foster, Epigenetic changes in childhood asthma. Dis Model Mech, 2009. 2(11-12): p. 549-53.

153. Patiño, N.M., Farmacología médica2008. 
154. EMEA.

http://www.emea.europa.eu/docs/en_GB/document_library/Scientific_guidel ine/2009/09/WC500002880.pdf. 2007.

155. FDA.

http://www.fda.gov/downloads/Regulatorylnformation/Guidances/ucm12929 6.pdf. 2008.

156. Lin, J.H., Pharmacokinetic and pharmacodynamic variability: a daunting challenge in drug therapy. Curr Drug Metab, 2007. 8(2): p. 109-36.

157. Roses, A.D., Pharmacogenetics and the practice of medicine. Nature, 2000. 405(6788): p. 857-65.

158. Roses, A.D., Pharmacogenetics and the practice of medicine. Nature, 2000. 405(6788): p. 857-865.

159. Health, N.I.o., National Asthma Education and Prevetion Program. Expert Panel Report 2. Guidelines for yhe Diagnosis and the Management of Asthma. Bethesda, MD: National Heart, Lung and Blood Institute, 1997. 974051.

160. Sayers, I. and I.P. Hall, Pharmacogenetic approaches in the treatment of asthma. Curr Allergy Asthma Rep, 2005. 5(2): p. 101-8.

161. Lima, J.J., et al., Pharmacogenetics of asthma. Curr Opin Pulm Med, 2009. 15(1): p. 57-62.

162. Tantisira, K.G., et al., Corticosteroid pharmacogenetics: association of sequence variants in CRHR1 with improved lung function in asthmatics treated with inhaled corticosteroids. Hum Mol Genet, 2004. 13(13): p. 13539.

163. Funk, C.D., Prostaglandins and leukotrienes: advances in eicosanoid biology. Science, 2001. 294(5548): p. 1871-5. 
164. Boie, Y., et al., Molecular cloning and characterization of the human prostanoid DP receptor. J Biol Chem, 1995. 270(32): p. 18910-6.

165. Bochenek, G., et al., Plasma 9alpha,11beta-PGF2, a PGD2 metabolite, as a sensitive marker of mast cell activation by allergen in bronchial asthma. Thorax, 2004. 59(6): p. 459-64.

166. Pettipher, R., T.T. Hansel, and R. Armer, Antagonism of the prostaglandin D2 receptors DP1 and $C R T H 2$ as an approach to treat allergic diseases. Nat Rev Drug Discov, 2007. 6(4): p. 313-25.

167. Narumiya, S., Y. Sugimoto, and F. Ushikubi, Prostanoid receptors: structures, properties, and functions. Physiol Rev, 1999. 79(4): p. 1193226.

168. Iniguez, M.A., et al., Prostanoid function and cardiovascular disease. Arch Physiol Biochem, 2008. 114(3): p. 201-9.

169. Tilley, S.L., T.M. Coffman, and B.H. Koller, Mixed messages: modulation of inflammation and immune responses by prostaglandins and thromboxanes. J Clin Invest, 2001. 108(1): p. 15-23.

170. Kanaoka, Y. and Y. Urade, Hematopoietic prostaglandin D synthase. Prostaglandins Leukot Essent Fatty Acids, 2003. 69(2-3): p. 163-7.

171. Oguma, T., K. Asano, and A. Ishizaka, Role of prostaglandin D(2) and its receptors in the pathophysiology of asthma. Allergol Int, 2008. 57(4): p. 307-12.

172. Ide, T., et al., Activation of nuclear receptors by prostaglandins. Thromb Res, 2003. 110(5-6): p. 311-5.

173. Hata, A.N. and R.M. Breyer, Pharmacology and signaling of prostaglandin receptors: multiple roles in inflammation and immune modulation. Pharmacol Ther, 2004. 103(2): p. 147-66. 
174. Hamm, H.E., How activated receptors couple to G proteins. Proc Natl Acad Sci U S A, 2001. 98(9): p. 4819-21.

175. Bos, C.L., et al., Prostanoids and prostanoid receptors in signal transduction. Int J Biochem Cell Biol, 2004. 36(7): p. 1187-205.

176. Arima, M. and T. Fukuda, Prostaglandin $D$ and $T(H) 2$ inflammation in the pathogenesis of bronchial asthma. Korean J Intern Med, 2011. 26(1): p. 818.

177. Chen, Y., B. Perussia, and K.S. Campbell, Prostaglandin D2 suppresses human NK cell function via signaling through $D$ prostanoid receptor. J Immunol, 2007. 179(5): p. 2766-73.

178. Holgate, S.T. and R. Polosa, Treatment strategies for allergy and asthma. Nat Rev Immunol, 2008. 8(3): p. 218-30.

179. Matsuoka, T., et al., Prostaglandin D2 as a mediator of allergic asthma. Science, 2000. 287(5460): p. 2013-7.

180. Woodward, D.F., et al., Studies on the ocular pharmacology of prostaglandin D2. Invest Ophthalmol Vis Sci, 1990. 31(1): p. 138-46.

181. Gerashchenko, D., et al., Strong rebound of wakefulness follows prostaglandin D2- or adenosine A2a receptor agonist-induced sleep. J Sleep Res, 2000. 9(1): p. 81-7.

182. Monneret, G., et al., Prostaglandin D2 is a potent chemoattractant for human eosinophils that acts via a novel DP receptor. Blood, 2001. 98(6): p. 1942-8.

183. Whittle, B.J., et al., Specificity between the anti-aggregatory actions of prostacyclin, prostaglandin E1 and D2 on platelets. Adv Exp Med Biol, 1985. 192: p. 109-25. 
184. O'Sullivan, S., et al., Increased urinary excretion of the prostaglandin D2 metabolite 9 alpha, 11 beta-prostaglandin F2 after aspirin challenge supports mast cell activation in aspirin-induced airway obstruction. J Allergy Clin Immunol, 1996. 98(2): p. 421-32.

185. Brannan, J.D., et al., Inhibition of mast cell PGD2 release protects against mannitol-induced airway narrowing. Eur Respir J, 2006. 27(5): p. 944-50.

186. Murray, J.J., et al., Release of Prostaglandin D2 into Human Airways during Acute Antigen Challenge. New England Journal of Medicine, 1986. 315(13): p. $800-804$.

187. Naclerio, R.M., et al., Mediator release after nasal airway challenge with allergen. Am Rev Respir Dis, 1983. 128(4): p. 597-602.

188. Charlesworth, E.N., et al., Prednisone inhibits the appearance of inflammatory mediators and the influx of eosinophils and basophils associated with the cutaneous late-phase response to allergen. J Immunol, 1991. 146(2): p. 671-6.

189. Tanaka, K., et al., Effects of prostaglandin D2 on helper $T$ cell functions. Biochem Biophys Res Commun, 2004. 316(4): p. 1009-14.

190. Gosset, P., et al., Prostaglandin D2 affects the maturation of human monocyte-derived dendritic cells: consequence on the polarization of naive Th cells. J Immunol, 2003. 170(10): p. 4943-52.

191. Yoshimura-Uchiyama, C., et al., Differential modulation of human basophil functions through prostaglandin D2 receptors DP and chemoattractant receptor-homologous molecule expressed on Th2 cells/DP2. Clin Exp Allergy, 2004. 34(8): p. 1283-90. 
192. Hirai, H., et al., Prostaglandin D2 selectively induces chemotaxis in $T$ helper type 2 cells, eosinophils, and basophils via seven-transmembrane receptor CRTH2. J Exp Med, 2001. 193(2): p. 255-61.

193. Xue, L., et al., Prostaglandin D2 causes preferential induction of proinflammatory Th2 cytokine production through an action on chemoattractant receptor-like molecule expressed on Th2 cells. J Immunol, 2005. 175(10): p. 6531-6.

194. Pettipher, R., The roles of the prostaglandin $D(2)$ receptors $D P(1)$ and CRTH2 in promoting allergic responses. Br J Pharmacol, 2008. 153 Suppl 1: p. S191-9.

195. Honda, K., et al., Prostaglandin D2 reinforces Th2 type inflammatory responses of airways to low-dose antigen through bronchial expression of macrophage-derived chemokine. J Exp Med, 2003. 198(4): p. 533-43.

196. Lilly, C.M. and L.J. Palmer, The role of prostaglandin D receptor gene in asthma pathogenesis. Am J Respir Cell Mol Biol, 2005. 33(3): p. 224-6.

197. Lilly, C.M., Diversity of asthma: evolving concepts of pathophysiology and lessons from genetics. J Allergy Clin Immunol, 2005. 115(4 Suppl): p. S526-31.

198. Arimura, A., et al., Prevention of allergic inflammation by a novel prostaglandin receptor antagonist, S-5751. J Pharmacol Exp Ther, 2001. 298(2): p. 411-9.

199. Hakonarson, H., et al., A major susceptibility gene for asthma maps to chromosome 14q24. Am J Hum Genet, 2002. 71(3): p. 483-91.

200. Mansur, A.H., et al., Suggestive evidence for genetic linkage between lgE phenotypes and chromosome 14q markers. Am J Respir Crit Care Med, 1999. 159(6): p. 1796-802. 
201. Daniels, S.E., et al., A genome-wide search for quantitative trait loci underlying asthma. Nature, 1996. 383(6597): p. 247-50.

202. Blakey, J.D., et al., Positionally cloned asthma susceptibility gene polymorphisms and disease risk in the British 1958 Birth Cohort. Thorax, 2009. 64(5): p. 381-7.

203. Oguma, T., et al., Role of prostanoid DP receptor variants in susceptibility to asthma. N Engl J Med, 2004. 351(17): p. 1752-63.

204. Tsai, Y.J., et al., The PTGDR gene is not associated with asthma in 3 ethnically diverse populations. J Allergy Clin Immunol, 2006. 118(6): p. $1242-8$

205. Leung, T.F., et al., PTGDR is not a major candidate gene for asthma and atopy in Chinese children. Pediatr Allergy Immunol, 2009. 20(6): p. 556-62.

206. Sanz, C., et al., Promoter genetic variants of prostanoid DP receptor (PTGDR) gene in patients with asthma. Allergy, 2006. 61(5): p. 543-8.

207. Sanz, C., et al., A new PTGDR promoter polymorphism in a population of children with asthma. Pediatr Allergy Immunol, 2009. 20(2): p. 151-6.

208. Zhu, G., et al., Association of PTGDR gene polymorphisms with asthma in two Caucasian populations. Genes Immun, 2007. 8(5): p. 398-403.

209. Li, J., et al., Lack of association between three promoter polymorphisms of PTGDR gene and asthma in a Chinese Han population. Int J Immunogenet, 2007. 34(5): p. 353-7.

210. Rogers, A.J., et al., Assessing the reproducibility of asthma candidate gene associations, using genome-wide data. Am J Respir Crit Care Med, 2009. 179(12): p. 1084-90. 
211. Standards for the diagnosis and care of patients with chronic obstructive pulmonary disease. American Thoracic Society. Am J Respir Crit Care Med, 1995. 152(5 Pt 2): p. S77-121.

212. Crapo, R.O., et al., Guidelines for methacholine and exercise challenge testing-1999. This official statement of the American Thoracic Society was adopted by the ATS Board of Directors, July 1999. Am J Respir Crit Care Med, 2000. 161(1): p. 309-29.

213. Comments on the LD50 and acute eye and skin irritation tests. The Animals in Research Committee of the Society of Toxicology and approved by the SOT Council. Fundam Appl Toxicol, 1989. 13(4): p. 621-3.

214. Patton S, S.S., Draft Best Practice Guidelines for Laboratory Internal Quality Control. European Molecular Genetics Quality Network, 2002.

215. Revzin, A., Gel electrophoresis assays for DNA-protein interactions. Biotechniques, 1989. 7(4): p. 346-55.

216. Allen, S.V. and E.S. Miller, RNA-binding properties of in vitro expressed histidine-tagged RB69 RegA translational repressor protein. Anal Biochem, 1999. 269(1): p. 32-7.

217. Grunwald, M.E., et al., Identification of a domain on the beta-subunit of the rod cGMP-gated cation channel that mediates inhibition by calciumcalmodulin. J Biol Chem, 1998. 273(15): p. 9148-57.

218. Scientific, $\mathrm{T}$. http://www.piercenet.com/proteomics/browse.cfm?fldid=7edac33e-39814e58-8a57-057a8280c68f. 2012.

219. Fried, M. and D.M. Crothers, Equilibria and kinetics of lac repressoroperator interactions by polyacrylamide gel electrophoresis. Nucleic Acids Res, 1981. 9(23): p. 6505-25. 
220. Russell, S.a., Molecular Cloning. A laboratory manual. Vol. 2. 2001, Unites States of America: COLD SPRING HARBOR LABORATORY PRESS. Cold Spring Harbor. New York.

221. Martin, C., et al., Improved chemiluminescent DNA sequencing. Biotechniques, 1991. 11(1): p. 110-3.

222. Chevalier, J., et al., Biotin and digoxigenin as labels for light and electron microscopy in situ hybridization probes: where do we stand? J Histochem Cytochem, 1997. 45(4): p. 481-91.

223. Didenko, V.V. and P.J. Hornsby, A quantitative luminescence assay for nonradioactive nucleic acid probes. J Histochem Cytochem, 1996. 44(6): p. 657-60.

224. Roche Applied Science, M., Alemania, Instruction Manual. DIG Gel Shift Kit, 2nd Generation., 2006.

225. Reed, K.C. and D.A. Mann, Rapid transfer of DNA from agarose gels to nylon membranes. Nucleic Acids Res, 1985. 13(20): p. 7207-21.

226. Laemmli, U.K., Cleavage of structural proteins during the assembly of the head of bacteriophage T4. Nature, 1970. 227(5259): p. 680-5.

227. Henzel, W.J., et al., Identifying proteins from two-dimensional gels by molecular mass searching of peptide fragments in protein sequence databases. Proc Natl Acad Sci U S A, 1993. 90(11): p. 5011-5.

228. Shevchenko, A., et al., Mass spectrometric sequencing of proteins silverstained polyacrylamide gels. Anal Chem, 1996. 68(5): p. 850-8.

229. Wacholder, S., et al., Assessing the probability that a positive report is false: an approach for molecular epidemiology studies. J Natl Cancer Inst, 2004. 96(6): p. 434-42. 
230. Shi, Y.Y. and L. He, SHEsis, a powerful software platform for analyses of linkage disequilibrium, haplotype construction, and genetic association at polymorphism loci. Cell Res, 2005. 15(2): p. 97-8.

231. Li, Z., et al., A partition-ligation-combination-subdivision EM algorithm for haplotype inference with multiallelic markers: update of the SHEsis (http://analysis.bio-x.cn). Cell Res, 2009. 19(4): p. 519-23.

232. Dausset, J.B. http://www.cephb.fr/en/index.php. 2009.

233. Isidoro-Garcia, M., et al., PTGDR gene in asthma: a functional, genetic, and epigenetic study. Allergy, 2011. 66(12): p. 1553-62.

234. Jamrozik, E.F., et al., Functional haplotypes in the PTGDR gene fail to associate with asthma in two Australian populations. Respirology, 2011. 16(2): p. 359-66.

235. Kim, S.H., et al., Association between polymorphisms in prostanoid receptor genes and aspirin-intolerant asthma. Pharmacogenet Genomics, 2007. 17(4): p. 295-304.

236. Bush, A. and A. Menzies-Gow, Phenotypic differences between pediatric and adult asthma. Proc Am Thorac Soc, 2009. 6(8): p. 712-9.

237. Moffatt, M.F., et al., A large-scale, consortium-based genomewide association study of asthma. N Engl J Med, 2010. 363(13): p. 1211-21.

238. Szczeklik, A. and M. Sanak, Genetic mechanisms in aspirin-induced asthma. Am J Respir Crit Care Med, 2000. 161(2 Pt 2): p. S142-6.

239. Storno, D.G.a.G.D., Finding regulatory elements in DNA sequence, in Bioinformatics: Methods express, M.L. Dahl, Editor 2007. 
240. Cartharius, K., et al., MatInspector and beyond: promoter analysis based on transcription factor binding sites. Bioinformatics, 2005. 21(13): p. 293342.

241. Science, W.I.o. http://www.genecards.org/. 2011.

242. Wu, X. and A.J. Levine, p53 and E2F-1 cooperate to mediate apoptosis. Proc Natl Acad Sci U S A, 1994. 91(9): p. 3602-6.

243. Helin, K., et al., Heterodimerization of the transcription factors E2F-1 and DP-1 leads to cooperative trans-activation. Genes Dev, 1993. 7(10): p. $1850-61$

244. Helin, K., E. Harlow, and A. Fattaey, Inhibition of E2F-1 transactivation by direct binding of the retinoblastoma protein. Mol Cell Biol, 1993. 13(10): $\mathrm{p}$. 6501-8.

245. Mahon, B.D., et al., The targets of vitamin $D$ depend on the differentiation and activation status of CD4 positive T cells. J Cell Biochem, 2003. 89(5): p. 922-32.

246. Ruhl, R., et al., Role of vitamin A elimination or supplementation diets during postnatal development on the allergic sensitisation in mice. Mol Nutr Food Res, 2007. 51(9): p. 1173-81.

247. Schuster, G.U., N.J. Kenyon, and C.B. Stephensen, Vitamin A deficiency decreases and high dietary vitamin $A$ increases disease severity in the mouse model of asthma. J Immunol, 2008. 180(3): p. 1834-42.

248. Pedro, M.P.d., Estudio epigenético del asma alérgica mediante el análisis de patrones de Metilación., en Unidad de Alergia e Inmunología Clínica. Departamento de Pediatría, Obstetricia y Ginecología.2010, Universidad de Salamanca. 
249. Hammad, H., et al., Prostaglandin D2 inhibits airway dendritic cell migration and function in steady state conditions by selective activation of the $D$ prostanoid receptor 1. J Immunol, 2003. 171(8): p. 3936-40.

250. Ramji, D.P. and P. Foka, CCAAT/enhancer-binding proteins: structure, function and regulation. Biochem J, 2002. 365(Pt 3): p. 561-75.

251. Couetil, L.L., et al., DNA binding activity of transcription factors in bronchial cells of horses with recurrent airway obstruction. Vet Immunol Immunopathol, 2006. 113(1-2): p. 11-20.

252. Lupo, A., et al., ZNF224: Structure and role of a multifunctional KRAB-ZFP protein. Int J Biochem Cell Biol, 2011. 43(4): p. 470-3.

253. Raud, J., et al., Enhancement of acute allergic inflammation by indomethacin is reversed by prostaglandin E2: apparent correlation with in vivo modulation of mediator release. Proc Natl Acad Sci U S A, 1988. 85(7): p. 2315-9.

254. Pavord, I.D., et al., Effect of inhaled prostaglandin E2 on allergen-induced asthma. Am Rev Respir Dis, 1993. 148(1): p. 87-90.

255. Philip, G., et al., Clinical studies of the DP1 antagonist laropiprant in asthma and allergic rhinitis. J Allergy Clin Immunol, 2009. 124(5): p. 942-8 e1-9. 
